\title{
DINÂMICA ESPACIAL E TEMPORAL DA CLOROSE VARIEGADA DOS CITROS
}

\author{
FRANCISCO FERRAZ LARANJEIRA BARBOSA \\ Engenheiro Agrônomo
}

Orientador: Prof. Dr. ARMANDO BERGAMIN FILHO

Dissertação apresentada à Escola Superior de Agricultura "Luiz de Queiroz", da Universidade de São Paulo, para a obtençảo do título de Mestre em Agronomia, Área de Concentração: Fitopatologia.

PIRACICABA

Estado de São Paulo - Brasil

Julho - 1997 
Dados Internacionais de catalogação na Publicação (CIP) DIVISÃO DE BIBLIOTECA E DOCUMENTAÇÃO - Campus "Luiz de Queiroz"/USP

Barbosa, Francisco Ferraz Laranjeira

Dinâmica espacial e temporal da clorose variegada dos citros / Francisco Ferraz Laranjeira Barbosa. - - Piracicaba, 1997.

144 p. : il.

Dissertaçāo (mestrado) - E Escola Superior de Agricultura Luiz de Queiroz, 1997.

Bibliografia.

1. Clorose variegada dos citros 2. Distribuiçăo espacial 3. Fruta citrica 4. Virus fitopatogênico l. Titulo

CDD 634.3

632.8 


\section{DINÂMICA ESPACIAL E TEMPORAL DA CLOROSE VARIEGADA DOS CITROS}

FRANCISCO FERRAZ LARANJEIRA BARBOSA

Aprovada em : 04.09.1997

Comissão Julgadora:

Prof.Dr. Armando Bergamin Filho ESALQ/USP

Profa. Dra. Lilian Amorim ESALQ/USP

Dr. Jorgino Pompeu Junior CCSMIIAC

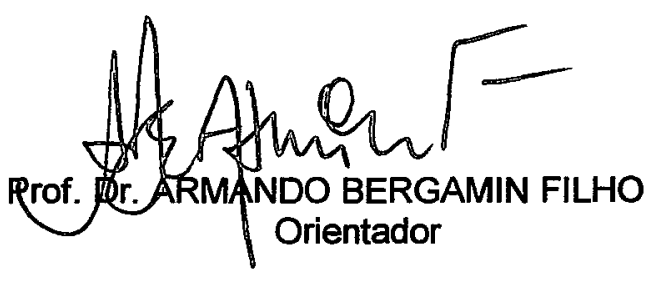


Dedico aos meus.

Ette, companheira, amiga e mulher.

Mira e Aum, pais e fonte de mim.

Pedro e Jacyra, irmãos e amigos.

Pedrinho, nossa renovação. 


\section{AGRADECIMENTOS}

Ao Centro de Citricultura Sylvio Moreira, ao Instituto Agronômico de Campinas e à Fundação IAC, na pessoa do Dr. Joaquim Teófilo Sobrinho, pela oportunidade.

À ESALQ/USP e Departamento de Fitopatologia, pela oportunidade.

Ao Prof. Dr. Armando Bergamin Filho, pela amizade, ensinamentos, apoio, orientação segura e precisa.

Ao Dr. Jorgino Pompeu Junior, pela amizade, paciência e norte constante nos caminhos citrícolas.

À Profa. Dra. Lilian Amorim, pela amizade, ensinamentos e apoio.

Aos técnicos Genésio Silvério da Silva e Luciano Garcia Borges pela inestimável ajuda na coleta dos dados.

Aos professores do Departamento de Fitopatologia ESALQ/USP, pelos ensinamentos.

Aos Drs. Otávio Sempionato (Estação Experimental de Citricultura de Bebedouro) e Weder Piffer (Fundecitrus-Barretos) pela ajuda na seleção das áreas experimentais.

Aos Drs. João Roberto Spotti Lopes da ESALQ/USP e Richard Berger da Universidade da Flórida, pelas valiosas observações.

Às fazendas São José (Bebedouro) e Carro Queimado (Colina) pela cessão das áreas experimentais.

À Estação Experimental de Citricultura de Bebedouro pelos dados climáticos.

A todos do Centro de Citricultura Sylvio Moreira - IAC e em especial ao Dr. José Orlando de Figueiredo, pelo apoio constante.

Ao Fundecitrus, pelo financiamento de parte desse trabalho. 


\section{SUMÁRIO}

Página

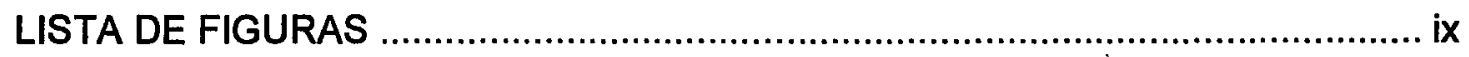

LISTA DE TABELAS

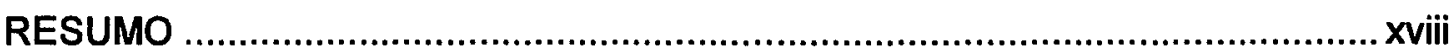

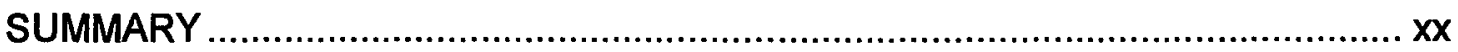

1. INTRODUÇÃO

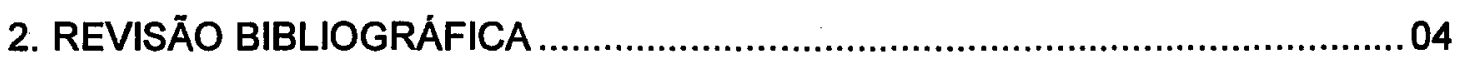

2.1. Análise da dinâmica de doenças ........................................................ 04

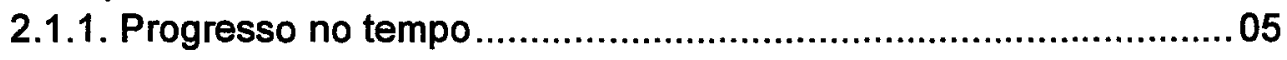

2.1.2. Distribuição espacial .................................................................. 07

2.2. Clorose Variegada dos Citros (CVC) .............................................. 12

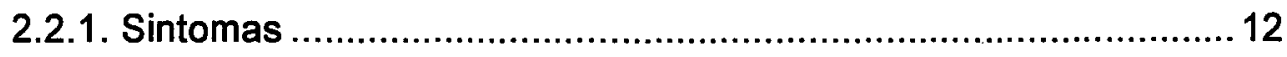

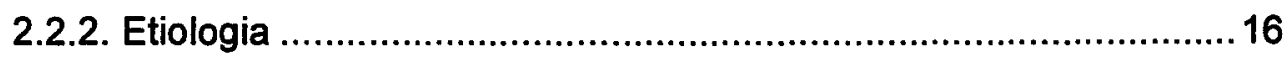

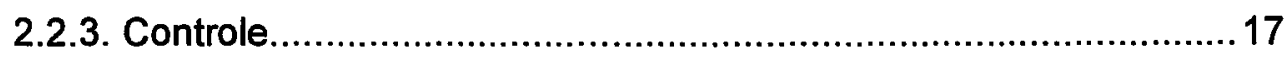

2.2.4. Epidemiologia da CVC ......................................................... 19

2.2.4.1. Disseminação .................................................................... 19

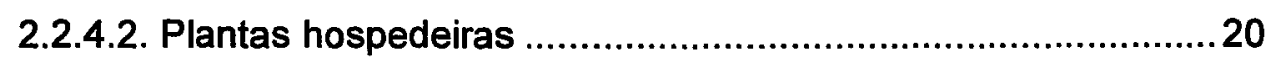

2.2.4.3. Aspectos temporais e espaciais.......................................... 22

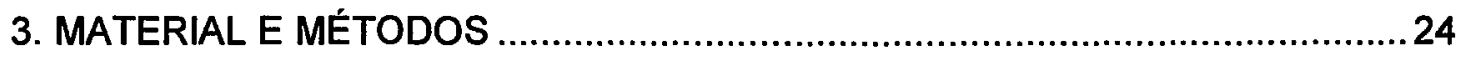

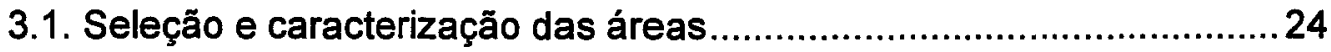

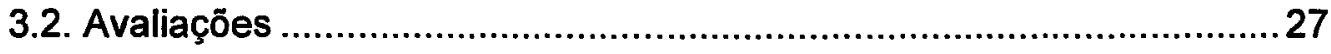

3.3. Ajustes de modelos de progresso temporal aos dados

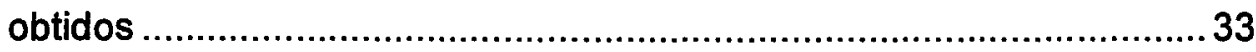


3.4. Quantificação da heterogeneidade espacial de plantas

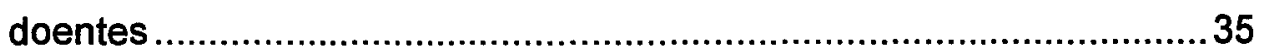

3.4.1. Análise de seqüências ordinárias (ASO) .................................... 35

3.4.2. Vizinho mais próximo e distância entre plantas

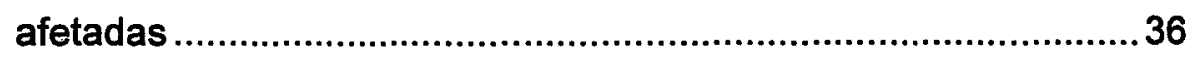

3.4.3. Índice de dispersão e aplicação da lei de Taylor

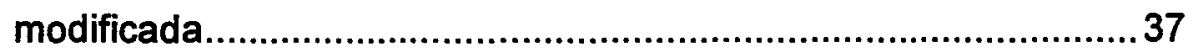

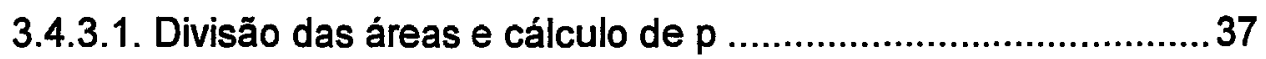

3.4.3.2. Aplicação da lei de Taylor modificada (HUGHES

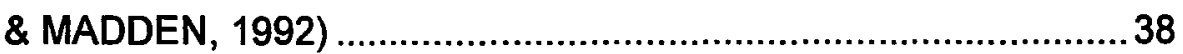

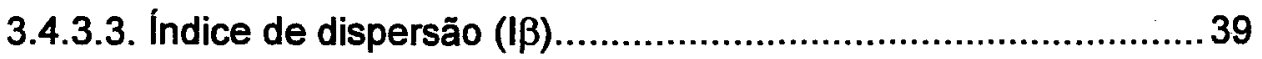

3.4.4. Determinação de áreas isópatas...............................................40

3.4.5. Análise de dinâmica e estrutura de focos (ADEF) .......................40

3.5. Variáveis climatológicas.....................................................................42

\section{RESULTADOS}

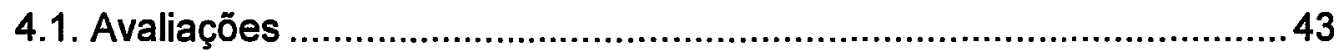

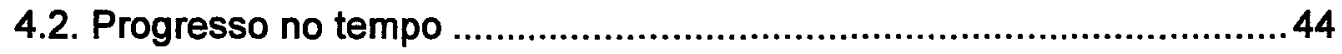

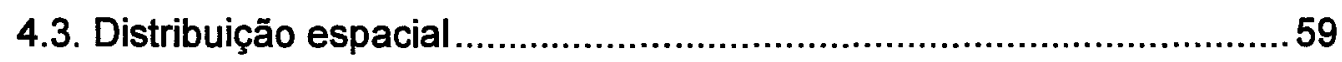

4.3.1. Análise de seqüências ordinárias (ASO).................................59

4.3.2. Vizinho mais próximo e distância entre plantas

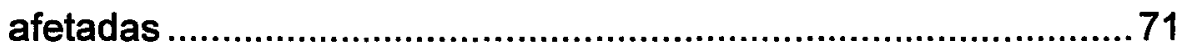

4.3.3. Aplicação da lei de Taylor modificada (LTM)..............................75

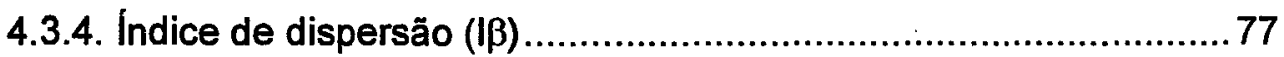

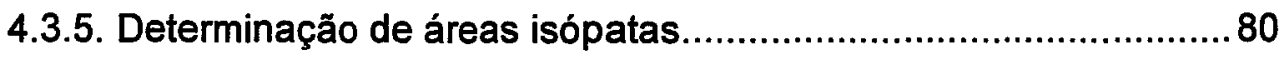

4.3.6. Análise de dinâmica e estrutura de focos (ADEF) ........................ 89

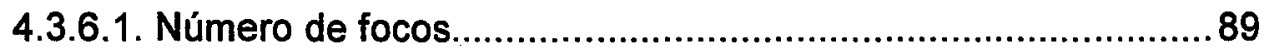

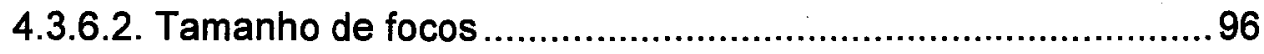

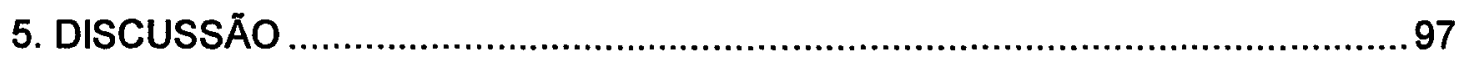

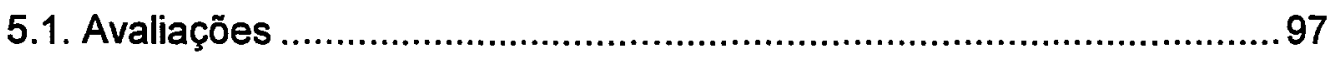




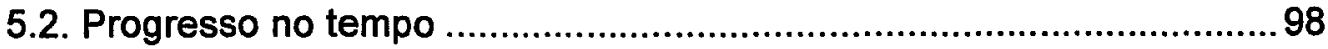

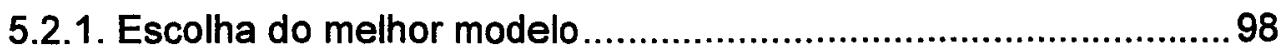

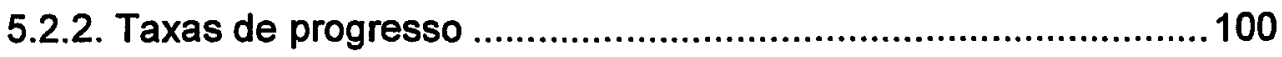

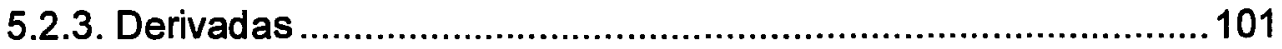

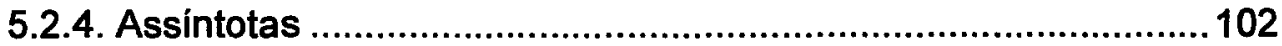

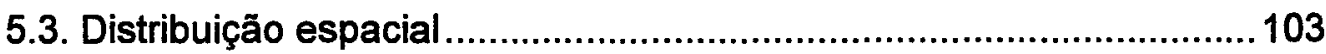

5.3.1. Análise de seqüências ordinárias...........................................103

5.3.2. Vizinho mais próximo e distância entre plantas afetadas............ 105

5.3.3. Aplicação da lei de Taylor modificada (LTM)............................. 106

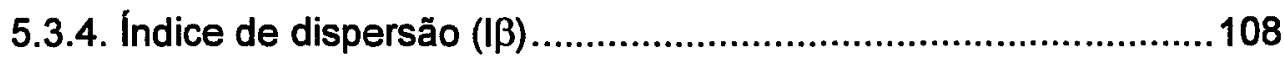

5.3.5. Determinação de áreas isópatas............................................... 109

5.3.6. Análise de dinâmica e estrutura de focos (ADEF) .....................114

5.4. Visão geral do patossistema e síntese ...........................................115

5.4.1. Variáveis climatológicas, crescimento do hospedeiro

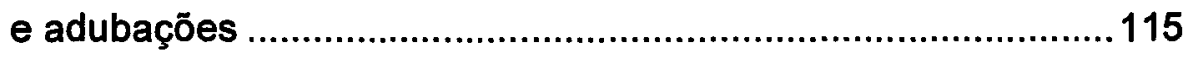

5.4.2. Ciclo da Clorose Variegada dos Citros: um modelo ................... 120

5.4.2.1. Detalhamento do modelo ................................................. 121

6. CONCLUSÕES

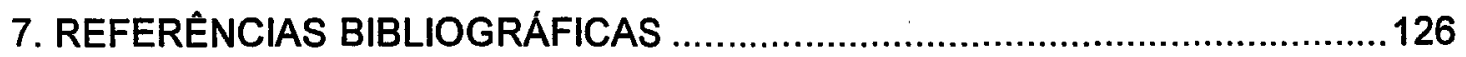




\section{LISTA DE FIGURAS}

Figura 1 - Sintomas foliares de Clorose Variegada dos Citros (CVC) 14

Figura 2 - Aspecto geral de planta afetada pela CVC 14

Figura 3 - Superbrotamento de ramos de planta afetada pela CVC 15

Figura 4 - Fruto de ramo sadio (centro) e frutos afetados pela CVC (laterais).....15

Figura 5 - Mapa de localização dos talhões SJ 01,SJ 01-2, SJ 01-3, SJ 01-4, SJ 01-5 e SJ 83, na fazenda São José, em Bebedouro, SP.

Figura 6 - Mapa de localização dos talhões SJ 73, SJ 67, SJ 71 e SJ 75, na fazenda São José, em Bebedouro, SP.

Figura 7 - Mapa de localização dos talhões $C Q H$ e CQN, na fazenda Carro Queimado, em Colina, SP.

Figura 8 - Mapa de localização do talhão CQP, na fazenda Carro Queimado, em Colina, SP.

Figura 9 - Posição relativa dos municipios de Colina (1), Bebedouro (2) e Piracicaba (3) em relação às DIRAs de São José do Rio Preto (vermelho), Barretos (amarelo), São Carlos (verde) e Campinas (azul), no Estado de São Paulo.

Figura 10 - Exemplo de foco e de padrões de proximidade considerados pela ADEF. O foco em vermelho denota a existência de padrão de proximidade longitudinal entre a unidade central e as demais. $O$ foco em preto e cinza denota a existência dos padrões de 
proximidade vertical e horizontal entre a unidade central e as demais. Para 0 foco em verde teríamos NPF $=11$; If $=4$; Ic $=5$; IFF $=1,25$ e ICF $=0,55$

Figura 11 - Curvas de progresso da CVC estimadas (linha continua) e dados originais (círculos) para os talhões SJ 01 (A), SJ 01-2 (B), SJ 01-3 (C), SJ 01-4 (D), SJ 01-5 (E), SJ 67 (F), SJ 71 (G), SJ $73(H)$, SJ 75 (I), SJ $83(\mathrm{~J})$ e CQH (K).

Figura 12 - Derivadas das curvas de progresso da CVC estimadas para os talhões SJ 01(A), SJ 01-2 (B), SJ 01-3 (C), SJ 01-4 (D), SJ 01-5 (E), SJ 67 (F), SJ $71(G)$, SJ $73(H)$, SJ 75 (I), SJ 83 (J) e CQH (K)...46

Figura 13 - Variação das taxas de progresso da CVC estimadas para os talhões SJ 01(A), SJ 01-2 (B), SJ 01-3 (C), SJ 01-4 (D), SJ 01-5 (E), SJ $67(F)$, SJ $71(G)$, SJ $73(H)$, SJ 75 (I), SJ 83 (J) e CQH (K)...47

Figura 14 - Médias da taxa de infecção da CVC ( $r$ ) para as quatro estações do ano, em 11 talhões. As letras acima das colunas identificam o resultado do teste Tukey a $5 \%$ de probabilidade; letras iguais significam que as médias não diferiram estatisticamente.

Figura 15 - Relação entre a precipitação pluviométrica mensal (círculos) e as derivadas das curvas de progresso da CVC (linha contínua) para os talhões SJ $01(A)$, SJ 01-2 (B), SJ 01-3 (C), SJ 01-4 (D), SJ 01-5 (E), SJ 67 (F), SJ $71(G)$, SJ 73 (H), SJ 75 (I), SJ 83 (J) e CQH (K). .55

Figura 16 -Relação entre a temperatura média mensal (círculos) e as derivadas das curvas de progresso da CVC (linha contínua) para os talhões SJ 01 (A), SJ 01-2 (B), SJ 01-3 (C), SJ 01-4 (D), SJ 01-5 (E), SJ 67 (F), SJ 71 (G), SJ 73 (H), SJ 75 (I), SJ $83(\mathrm{~J})$ e CQH (K). 
Figura 17 - Relação entre umidade relativa do ar mensal média (círculos) e as derivadas das curvas de progresso da CVC (linha contínua) para os talhões SJ 01 (A), SJ 01-2 (B), SJ 01-3 (C), SJ 01-4 (D), SJ 01-5 (E), SJ 67 (F), SJ 71 (G), SJ 73 (H), SJ 75 (I), SJ $83(J)$ e $C Q H(K)$.

Figura 18 - Relação inversa entre o logaritmo neperiano do inóculo inicial (p2) e a taxa média de infecção $\left(r_{m}\right)$ das onze áreas avaliadas.

Figura 19 - Mapas de seis avaliações representativas (11/94, 01/95, 03/95, $11 / 95,01 / 96$ e 03/96) do talhão SJ 01. Cada quadrado preto representa uma planta sintomática.

Figura 20 - Mapas de seis avaliações representativas (11/94, 01/95, 03/95, 11/95, 01/96 e 03/96) dos talhões SJ 01-2 (A), SJ 01-3 (B), SJ 01-4 (C) e SJ 01-5 (D). Cada quadrado preto representa uma planta sintomática.

Figura 21 - Mapas de quatro avaliações representativas $(01 / 95,05 / 95,11 / 95$ e 03/96) do talhão SJ 83. Cada quadrado preto representa uma planta sintomática 63

Figura 22 - Mapas de seis avaliações representativas (11/94, 01/95, 03/95, $11 / 95,01 / 96$ e 03/96) do talhão SJ 73 . Cada quadrado preto representa uma planta sintomática 64

Figura 23 - Mapas de seis avaliações representativas $(11 / 94,01 / 95,05 / 95$, $11 / 95,01 / 96$ e 03/96) do talhão SJ 67 . Cada quadrado preto representa uma planta sintomática 65

Figura 24 - Mapas de seis avaliações representativas (11/94, 01/95, 05/95, $09 / 95,11 / 95$ e 01/96) do talhão SJ 71 . Cada quadrado preto 
representa uma planta sintomática

Figura 25 - Mapas de seis avaliações representativas (11/94, 01/95, 05/95, 11/95, 01/96 e 03/96) do talhão SJ 75. Cada quadrado preto representa uma planta sintomática

Figura 26 - Mapas de três avaliações representativas (01/95, 11/95 e 03/96) do talhão $\mathrm{CQH}$. Cada quadrado preto representa uma planta sintomática 68

Figura 27 - Mapas da primeira (01/95) e última avaliação (03/96) do talhão CQN. Cada quadrado preto representa uma planta sintomática.

Figura 28 - Mapas da primeira (01/95) e última avaliação (03/96) do talhão CQP. Cada quadrado preto repreenta uma planta sintomática 70

Figura 29 - Percentagem de linhas agregadas para seis talhões em dez épocas, de acordo com a análise de seqüêcias ordinárias.

Figura 30 - Evolução da distância média (em metros) entre plantas doentes para o talhão SJ 01 ao longo de dez avaliações 72

Figura 31 - Aplicação da lei de Taylor modificada. Relação entre o logaritmo da variância observada (ćŕculos) e o logaritmo da variância binomial (linha continua) para os talhões SJ 67 (A), SJ 71 (B), SJ 75 (C), SJ 73 (D), SJ 01 (E) e CQH (F). 76

Figura 32 - Aplicação da lei de Taylor modificada. Relação entre o logaritmo da variância observada (ćrculos) e o logaritmo da variância binomial (linha contínua) para as informações agrupadas dos seis talhões, totalizando 52 pares de dados 78

Figura 33 - Evolução dos valores do índice de dispersão (I $\beta)$ para os talhões 
SJ 67, SJ 71, SJ 75, SJ73, SJ 01 e CQH. Os índices marcados com * não diferiram estatisticamente da unidade

Figura 34 -Áreas isópatas do talhão SJ 01 em seis avaliações representativas (11/94, 01/95, 03/95, 11/95, 01/96 e 03/96). O aumento na incidência da doença é indicado pela variação de cores, do verde (menor incidência) ao vermelho escuro (maior incidência)

Figura 35 - Áreas isópatas do talhão SJ 73 em seis avaliações representativas $(11 / 94,01 / 95,03 / 95,11 / 95,01 / 96$ e 03/96). $\mathrm{O}$ aumento na incidência da doença é indicado pela variação de cores, do verde (menor incidência) ao vermelho escuro (maior incidência).

Figura 36-Áreas isópatas do talhão SJ $67 \mathrm{em}$ seis avaliações representativas (11/94, 01/95, 05/95, 11/95, 01/96 e 03/96). 0 aumento na incidência da doença é indicado pela variação de cores, do verde (menor incidência) ao vermelho escuro (maior incidência)

Figura 37 -Áreas isópatas do talhão $S J 71$ em seis avaliações representativas (11/94, 01/95, 05/95, 09/95, 11/95 e 01/96). O aumento na incidência da doença é indicado pela variação de cores, do verde (menor incidência) ao vermelho escuro (maior incidência).

Figura 38 - Áreas isópatas do talhão SJ 75 em seis avaliações representativas (11/94, 01/95, 05/95, 11/95, 01/96 e 03/96). O aumento na incidência da doença é indicado pela variação de cores, do verde (menor incidência) ao vermelho escuro (maior incidência) 
Figura 39-Áreas isópatas do talhão $\mathrm{CQH}$ em três avaliações representativas $(01 / 95,11 / 95$ e 03/96). O aumento na incidência da doença é indicado pela variação de cores, do verde (menor incidência) ao vermelho escuro (maior incidência)

Figura 40 - Áreas isópatas dos talhões CQN e CQP para a última avaliação (03/96). O aumento na incidência da doença é indicado pela variação de cores, do verde (menor incidência) ao vermelho escuro (maior incidência)

Figura 41 - Número de reboleiras (NRM) e focos unitários (NF1M) - A - e número total de focos por 1000 plantas (NFM) - B - em função da incidência. Dados agrupados dos talhões SJ 01, SJ 67, SJ 71, SJ 73, SJ 75, SJ 83 e CQH

Figura 42 - Tamanho de focos. Relação entre o número médio de plantas por foco e proporção de plantas afetadas. Dados agrupados dos talhões SJ 01, SJ 67, SJ 71, SJ 73, SJ 75, SJ 83 e CQH.

Figura 43 - Evolução do número total de focos por 1000 plantas (NFM) para os talhões SJ 67, SJ 71 e SJ 75, com os respectivos picos de NFM .92

Figura 44 - Relação entre a percentagem de focos unitários e proporção de plantas afetadas. Dados agrupados dos talhões SJ 01, SJ 67 , SJ 71, SJ 73, SJ 75, SJ 83 e CQH. O percentual é em função do número total de focos 93

Figura 45 - Distribuição de freqüência do número de focos em função do número médio de plantas por foco para o talhão $\$ J 71 \mathrm{em}$ cinco avaliações. 94

Figura 46 - Distribuição de freqüência do número de focos em função do 
número médio de plantas por foco para o talhão $S J 75 \mathrm{em}$ cinco avaliações

Figura 47 - Representação do histórico dos talhões SJ 67, SJ 71 e SJ 75. A: situação original, com pomares velhos nas três áreas. B: replantio do SJ 71 após arranquio do pomar inicial (1991). C: replantio do SJ 67 após arranquio do pomar inicial (1992). D: replantio do SJ 75 após arranquio do pomar inicial (1993). Notar diferença de crescimento entre as três áreas, representada por tamanhos diferentes de figuras de árvores............112

Figura 48 - Dados climáticos mensais obtidos na Estação Experimental de Citricultura de Bebedouro para o período do estudo, em que: precipitação pluviométrica em milímetros de chuva (barras verticais); umidade relativa do ar média (círculos pretos); temperatura máxima média em graus Celsius (círculos brancos); temperatura média em graus Celsius (quadrados pretos); e temperatura mínima média em graus Celsius (quadrados brancos) 


\section{LISTA DE TABELAS}

Tabela 1 - Coeficientes de determinação $\left(R^{2}\right)$, parâmetro $p 1$, e ocorrência de padrões no residuo $(P R)$ estimados por regressão não-linear para seis modelos de padrão duplo sigmóide em cada talhão.....................48

Tabela 2 - Valores estimados dos parâmetros da equação logística generalizada de 5 parâmetros para cada talhão

Tabela 3 - Valores médios e mínimos estimados para taxa de infecção, tempo para ocorrência dos valores mínimos, em meses, e época do ano em que ocorreram

Tabela 4 - Valor estimado para o inóculo inicial $\left(e^{p 2}\right)$, em proporção de plantas afetadas, para cada talhão.

Tabela 5 - Taxas de infecção estimadas para cada estação do ano, para cada talhão, a partir do modelo logístico generalizado de 5 parâmetros

Tabela 6 - Coeficientes de correlação $\left(R^{2}\right)$ entre as derivadas das curvas de progresso estimadas para cada talhão e variáveis climáticas, e a probabilidade de erro associada a cada correlação $(P)$

Tabela 7 - Índice de agregação geral de seis talhões em 10 épocas, calculado pela análise de seqüências ordinárias

Tabela 8 - Incidência de CVC (em percentagem de plantas afetadas)e indices Clark \& Evans (CE) para onze talhões em dez épocas .73

Tabela 9 - Estudo de distância entre plantas doentes em 11 talhões. .74 
Tabela 10 - Valores dos parâmetros $b$ e $A$ da equação de ajuste à lei de Taylor modificada e significância de $b$ ao nível de $5 \%$ de probabilidade pelo teste $t$ para seis talhões .......................................75

Tabela 11 - Direções predominantes da disseminação da CVC em seis talhões, em relação aos pontos cardeais. $O$ sinal \# indica ausência de direção predominante 
Autor: Francisco Ferraz Laranjeira Barbosa Orientador: Prof. Dr. Armando Bergamin Filho

\section{RESUMO}

A Clorose Variegada dos Citros (CVC) é a mais importante doença dos citros no Brasil, mas sua epidemiologia ainda não havia sido estudada. O presente trabalho objetivou a caracterização da dinâmica temporal e espacial da clorose variegada dos citros.

Por meio de avaliação de sintomas visuais, foram mapeados, bimestralmente, onze talhões de laranja-doce cultivares Pera, Hamlin e Natal, em duas fazendas da região norte do Estado de São Paulo, nos municípios de Bebedouro e Colina, no período de setembro de 1994 a março de 1996.

Para a avaliação da dinâmica no tempo, os dados de cada avaliação em cada área foram transformados em proporção de plantas sintomáticas e seis modelos com padrão duplo sigmóide foram ajustados aos dados (logístico, monomolecular e Gompertz generalizados de quatro e cinco parâmetros). 0 modelo logístico de cinco parâmetros foi o que apresentou melhor ajuste, para o período considerado. Tendo apresentado padrão duplo sigmóide, houve diferenças nas taxas de progresso da doença entre as estaçōes do ano. As taxas médias da primavera e verão foram estatisticamente superiores às do outono e inverno, pelo teste Tukey a $5 \%$ de probabilidade de erro.

Para o estudo da dinâmica espacial, foram aplicadas as seguintes análises: seqüências ordinárias; vizinho mais próximo; áreas isópatas; lei de Taylor modificada; índice de dispersão e análise de dinâmica e estrutura de focos. Pelo teste de seqüências ordinárias, foi demonstrada a pequena proporção de linhas de plantio 
com agregação significativa de plantas doentes, indicando ausência de influência de passagem de máquinas na disseminação da doença.

O teste do vizinho mais próximo, por meio do indice de Clark \& Evans, demonstrou a presença de agregação de plantas doentes quando se considera o talhão como um todo. Da mesma forma, os índices de dispersão e a lei de Taylor modificada apresentaram resultados semelhantes.

A análise de áreas isópatas demonstrou, além da agregação de plantas doentes, sua tendência a se localizarem nas bordas dos talhões, notadamente quando na vizinhança de outros talhőes contaminados. Foi demonstrada também a ausência de efeito da direção dos ventos predominantes na disseminação da CVC, nos talhões avaliados.

A análise de dinâmica e estrutura de focos revelou que o número de focos por mil plantas cresceu com o aumento da incidência da doença, até $30 \%$ de plantas com sintomas. A partir de $30 \%$, houve coalescência de focos. Os focos de CVC são em sua maioria isodiamétricos e diminuem sua compacidade conforme a incidência aumenta. $O$ aumento no número médio de plantas por foco seguiu um padrão exponencial e $83 \%$ dos focos apresentaram menos de 10 plantas. Em contrapartida, o percentual de focos unitários diminuiu conforme o aumento na incidência. 


\section{SPATIAL AND TEMPORAL DYNAMICS OF CITRUS VARIEGATED CHLOROSIS}

Author: Francisco Ferraz Laranjeira Barbosa Adviser: Prof. Dr. Armando Bergamin Filho

\section{SUMMARY}

Citrus Variegated Chlorosis (CVC) is the most important citrus disease in Brazil but its epidemiology had not been studied yet. The objective of the present work was characterize the temporal and spatial dynamics of citrus variegated chlorosis.

By visual symptoms assessments, between september, 1994 and march, 1996, eleven groves of Pêra, Hamlin and Natal sweet oranges were bimonthly mapped in two farms of north region of São Paulo state, Brazil, in Bebedouro and Colina counties.

For temporal characterization, data of each evaluation of each area were transformed in proportion of symptomatic plants and six models of double sigmoid pattern were fitted to data (generalized logistic, monomolecular and Gompertz of four and five parameters). The generalized logistic of five parameters obtained the best fit. The disease infection rates varied between seasons and the mean rates for spring and summer were higher than autumm and winter mean rates (Tukey multiple range test, $\mathrm{P}<0.05$ ).

For spatial dynamics study, were applied the following techniques: ordinary runs; nearest neighbour; isopath areas; modified Taylor law; dispersion index and analysis of foci dynamics and structure. By ordinary runs test was showed a low proportion of rows with non-random pattern of diseased plants, indicating no influence of machine based cultural practices on disease spreading. The nearest neighbour test was performed using the Clark \& Evans index and showed an overall clustered pattern 
of diseased trees. So did dispesion index and modified Taylor law that presented similar results.

The isopath areas analysis showed, besides diseased plants clustering, a tendency for the diseased plants being at groves edges, specially when groves were near infected ones. It was demonstrated the non-influence of wind direction on CVC spreading, at least at evaluated groves.

The analysis of foci dynamics and structure revealed that number of foci per one thousand plants raised with the disease incidence until $30 \%$ of symptomatic plants, when foci coalescence took place. The CVC foci were mostly isodiametric and had got less compacity as incidence increased. The increasing of mean number of diseased plants per focus followed an exponential pattern and $83 \%$ of foci had less than ten plants. The proportion of unitary foci decreased as incidence increased. 


\section{INTRODUÇĀO}

A citricultura é um dos mais importantes setores da agricultura brasileira. Em São Paulo, maior produtor do Brasil, ocupava a segunda posição com $13,79 \%$ do valor da produção agrícola, no ano 1994/95 (OLIVETTI et alii, 1996). Sua importância é devida tanto ao lado social de geração de emprego nas lavouras, armazéns e indústrias, quanto ao lado econômico, por serem os produtos cítricos (suco concentrado, óleo essencial, etc.) importantes fontes de divisa por meio de sua exportação e/ou comercialização interna.

Sendo amplamente explorada em base monocultural, a citricultura vem ao longo dos anos deparando-se com uma série de doenças: Sorose, Exocorte, Tristeza, com grande disseminação através de material propagativo. A Clorose Variegada dos Citros (CVC), também chamada de "Amarelinho" ou Mal de Macaubal, foi observada pela primeira vez em 1987, em pomares do Triângulo Mineiro, nos municipios de Prata, Uberlândia e Uberaba.

Os primeiros a observar a nova anomalia acreditaram tratar-se de desordem nutricional, pois as folhas apresentavam sintomas de deficiência de zinco e os frutos, muito pequenos, indicavam carência de potássio. No entanto, e ao contrário do que era esperado, a anomalia apresentou rápida disseminação, logo atingindo regiões produtoras de citros do Norte e Oeste do Estado de São Paulo (ROSSETI \& DE NEGRI, 1990).

A CVC já foi observada nas principais variedades de laranja doce (LARANJEIRA et alii, 1995), em lima ácida Tahiti (BERETTA et alii, 1993) e em algumas tangerinas e híbridos (POMPEU Jr. et alii, 1994). Uma doença similar à CVC 
foi constatada também na Argentina, onde é chamada de "Pecosita" ou "Falsa Mancha Grascienta" (BERETTA et alii,1992; CONTRERAS, 1992). No Brasil, estimase que as perdas sejam superiores a 100 milhōes de dólares por ano (PREJUízO..., 1997).

A CVC é causada por uma bactéria fastidiosa limitada ao xilema (Xylella fastidiosa) (BERETTA et alii, 1993), transmitida por cigarrinhas - Hemiptera: Cicadellidae - (LOPES et alii, 1996; ROBERTO et alii, 1996), como acontece com outras doenças causadas pelo mesmo patógeno (AGRIOS, 1988). Além dessas informações, pouco se sabe sobre a epidemiologia da doença (GOTTWALD et alii, 1993). Até o momento, quase toda práxis é orientada por suposições inferidas a partir do conhecimento epidemiológico de patossistemas que englobam essa bactéria.

Mesmo para doenças com epidemiologia bem conhecida, os aspectos temporais têm sido enfatizados em detrimento dos espaciais (JEGER, 1989). Um conhecimento mais amplo de todas as características de uma epidemia, não só temporais, mas também espaciais, permite uma visão mais íntima da estrutura do patossistema e de seu funcionamento (JEGER, 1989), e uma série de informações podem ser extraídas, sejam de caráter puramente acadêmico, sejam com grande carga de praticidade, traduzidas em benefícios diretos:

i) otimizar planos de amostragem (MARCUS et alii, 1984; LECOUSTRE et alii, 1989);

ii) compreeder a dinâmica populacional de um patógeno (GILLIGAN, 1983);

iii) correlacionar doenças e vetor(es) e, mais especificamente, a doença e o nicho ecológico do(s) vetor(es) (AUBERT et alii, 1984; MARCUS et alii, 1984);

iv) comparar variedades com maior precisão frente a uma doença (NELSON \& CAMPBELL, 1993);

v) caracterizar o padrão ou padrões de disseminação da doença (NELSON \& CAMPBELL, 1993; RISTAINO et alii, 1993); 
vi) correlacionar tratos culturais e disseminação da doença, e entre esta e condições ambientais (AGOSTINI et alii, 1993; CAMPBELL \& VAN DER GAAG, 1993);

vii) caracterizar as relações entre 0 patógeno e antagonistas ou organismos que atuam em sinergismo;

viii) inferir a respeito da forma de transmissão da doença (LARANJEIRA et alii, 1993);

ix) subsidiar delineamento de estratégias de controle e/ou avaliação de sua eficácia (AUBERT et alii, 1984);

x) correlacionar a população do patógeno com variação das características físico-químicas do solo (KRAFT \& ALLMARAS, 1985; NOE \& BARKER, 1985);

xi) inferir sobre centros de origem dos patógenos (ZENTMEYER, 1985).

Dessa forma, o objetivo do presente trabalho foi estudar tanto 0 progresso da Clorose Variegada dos Citros no tempo, quanto o arranjo espacial das plantas afetadas, visando caracterizar a dinâmica da doença. 


\section{REVISÃO BIBLIOGRÁFICA}

\subsection{Análise da dinâmica de doenças}

Uma epidemia é o progresso da doença no tempo e no espaço (KRANZ, 1990). Sendo doença a resultante de interação compatível entre patógeno e hospedeiro sob a influência do ambiente (físico e biológico) e da interferência humana, a epidemiologia pode ser dita como a ciência fitopatológica aplicada ao nível de população ou de comunidade (KRANZ, 1990).

Desde VAN DER PLANK (1963), precursor da moderna epidemiologia vegetal, a grande maioria das análises de epidemias são feitas quase exclusivamente dentro da abrangência do progresso temporal (JEGER, 1989). Por meio do ajuste de equações simples aos dados obtidos é possivel caracterizar como a doença progride (VAN DER PLANK, 1963) e, mais ainda, comparar epidemias desenvolvidas sob diferentes condiçōes (KRANZ, 1988). Assim, as informaçōes extraídas desse tipo de estudo como, por exemplo, a taxa aparente de infecção, a assíntota máxima e o inóculo inicial, têm sido usadas para comparar variedades (AMORIM et alii, 1993a), eficiência de fungicidas (BERGER, 1977),' eficiência da prática de "roguing" (BERGER, 1977), enfim, quantificar a influência de práticas culturais ou condiçōes ambientais no progresso de uma doença. Apesar da importância capital do aspecto temporal, o estudo de um patossistema não se completa até que se conheça como a doença se distribui num campo de cultivo e quais os fatores responsáveis pelo arranjo espacial observado. Fatores biológicos e ambientais e mesmo tratos culturais podem influenciar a evolução de uma epidemia (DHANVATARI \& DIRKS, 1987) e sua atuação nem sempre é uniforme. Assim, a manifestação de uma doença pode assumir padrões, os quais, quando devidamente caracterizados, ajudam a explicar os 
fatores que atuaram e a sua real importância na epidemia. Portanto, é crucial para a epidemiologia a obtenção não só de dados de progresso da doença no tempo, mas também informações relativas ao arranjo espacial de plantas doentes e, em última instância, dos patógenos. Dessa forma, de acordo com CAMPBELL \& MADDEN (1990), a descrição dos atributos espaciais de populações de patógenos e plantas doentes é essencial para o correto delineamento de experimentos, para programas de amostragem, para estudos de manejo da doença e, ainda, para a própria epidemiologia, como ciência.

\subsubsection{Progresso no tempo}

A análise do progresso temporal de doenças é a maneira mais rápida e eficiente de se estudar epidemias de forma objetiva. Nessa linha, a obtenção de curvas de progresso da doença (CPD) ${ }^{1}$ é o passo inicial nessa análise. As CPD podem ser consideradas a impressão digital da epidemia por reunir, num gráfico cartesiano simples, as informaçōes essenciais do sistema. Em outras palavras, as CPD são o sumário de qualquer epidemia, representando todos os processos e interações entre componentes do patossistema. As CPD podem ser obtidas para qualquer tipo de hospedeiro, seja perene ou anual. A construção das CPD independe das condiçōes climáticas e a área de obtenção dos dados pode ter qualquer tamanho, desde poucas plantas, até dimensões continentais. Patossistemas os mais diversos são passiveis de caracterização pela sua CPD; assim desde micoses até viroses podem ser analisadas. A duração da epidemia não limita o uso da CPD e, tanto as poliéticas quanto as explosivas podem ser estudadas através dessas curvas. Nessa linha, não importa se a doença aumenta de intensidade, diminui ou não tem seu status alterado; de qualquer forma pode ser analisada (CAMPBELL \& MADDEN, 1990; KRANZ, 1990; MADDEN \& CAMPBELL, 1990; BERGAMIN FILHO \& AMORIM, 1996).

\footnotetext{
${ }^{1}$ Curva de progresso da doença: representação cartesiana de intensidade de doença (incidência ou severidade) por tempo cronológico ou fenológico.
} 
Diversas características das CPD podem ser usadas na análise das epidemias. Dentre as mais importantes, pode-se destacar a taxa de progresso (r), a assíntota máxima, a duração da epidemia e também a área abaixo da curva de progresso da doença (AACPD). Esses descritores podem ser utilizados não só na caracterização das epidemias, mas também na comparação da influência de diversos fatores no comportamento desses sistemas (CAMPBELL \& MADDEN, 1990; KRANZ, 1990; MADDEN \& CAMPBELL, 1990; BERGAMIN FILHO \& AMORIM, 1996). Dessa forma, podem ser encontrados estudos epidemiológicos que testam o efeito de sistemas de cultivo (CARMO et alii, 1994), reação de fitogenótipos à doença (AMORIM et alii, 1993a; BOITEUX \& REIFSCHNEIDER, 1993), condições climáticas (SHTIENBERG et alii, 1996), métodos de controle (BERGER, 1977; BERGER, 1988); enfim, estudos que usam as características das CPD para testar hipóteses direcionadas à prática agrícola. Por outro lado, a análise das CPD pode ser usada em estudos de epidemiologia comparativa, quando o enfoque é muito mais de desenvolvimento de princípios e conceitos (KRANZ, 1988), ou como base para a criação de sistemas de previsão de doença ou de simuladores (MADDEN \& ELLIS, 1988; HAU, 1988).

Após o trabalho primordial de VAN DER PLANK (1963), as CPD foram muito associadas a uma de suas características, qual seja, a forma. Ainda hoje utilizase, erroneamente, os termos "doença de juros simples" e "doença de juros compostos" para definir doenças cujas curvas são do tipo monomolecular ou sigmóide, respectivamente. Obviamente, CPD, quaisquer que sejam seu formato, podem ser associadas a modelos matemáticos simples, que captam, em poucos parâmetros, a essência da epidemia. Dentre os modelos mais comuns no estudo de epifitias, pode-se destacar o logístico e o monomolecular, mas também o modelo de Gompertz, cuja eficiência em descrever epidemias em plantas foi bem identificada por BERGER (1981).

A escolha do melhor modelo na representação dos dados obtidos é feita após seu ajuste ao dados, por meio de análises de regressão. Qualquer que seja - modelo, a sua escolha depende de alguns critérios essenciais (CAMPBELL \& MADDEN, 1990; MADDEN \& CAMPBELL, 1990; BERGAMIN FILHO \& AMORIM, 
1996). Dentre esses critérios pode-se destacar o coeficiente de determinação $\left(R^{2}\right)$ entre dados obtidos e dados previstos pelos modelos. Um outro critério muito importante é a verificação da existência de padrōes no gráfico de resíduos, seja em função do tempo, que é a variável independente desses modelos, seja em função dos valores previstos pelo modelo. Idealmente, os valores dos resíduos devem ser próximos de zero e estar aleatoriamente distribuídos no gráfico, sem apresentar tendências a super ou subestimar a doença, qualquer que seja a fase da epidemia. Além desses critérios, pode-se avaliar a adequação dos modelos em função das estimativas de desvio padrão dos parâmetros das equaçōes, bem como por meio do formato da curva de derivadas que, via de regra, apresenta-se com formato específico para cada modelo.

\subsubsection{Distribuição espacial}

A caracterização de atributos espaciais é comum em ecologia geral (GREIG-SMITH, 1983) e entomologia (TAYLOR, 1984). Os princípios e métodos desse tipo de estudo, na sua maioria, foram gerados por aquelas duas ciências e a fitopatologia tem procurado se valer desses conhecimentos e aplicá-los, especificamente, no entendimento dos patossistemas.

De forma geral, existem três padrōes de arranjo espacial: regular, aleatório e agregado. Como em fitopatologia o primeiro tipo é raro (CAMPBELL \& MADDEN, 1990), os dois últimos é que são alvo das análises e podem ser definidos da seguinte maneira: distribuição aleatória ocorre quando o conhecimento da localização de um individuo (entidade sintomática) não fornece nenhuma informação sobre a localização de qualquer outro indivíduo; ou os valores para cada par de unidades $i$ e $j$ (locais ou áreas) não são correlacionados (MADDEN, 1989). Distribuição agregada ocorre quando a localização de um individuo, em um ponto determinado, aumenta a probabilidade de que outros pontos próximos a ele estejam ocupados por individuos semelhantes; ou os valores para cada par de unidades $i$ e $j$ (locais ou áreas) são correlacionados (MADDEN, 1989). 
Existem três classes básicas de métodos de análise de arranjos espaciais (CAMPBELL \& MADDEN, 1990):

i) estudo da seqüência de plantas doentes e sadias na área avaliada;

ii) análises através de quadrats ${ }^{2}$ dispostos em malhas, transects ${ }^{3}$ ou aleatoriamente ao longo da área experimental;

iii) análise de medidas de distância.

A primeira dessas classes engloba a Análise de Seqüências Ordinárias (ASO), onde cada conjunto de elementos do mesmo tipo (i.e., plantas sadias ou doentes) é considerado uma seqüência. $O$ número de grupos de plantas doentes é comparado com o número esperado sob a hipótese de aleatoriedade. Quanto mais agregadas as entidades sintomáticas estiverem, menos grupos (seqüências) serão observados. O uso dessa técnica tem sido amplo (CAMPBELL \& MADDEN, 1990), principalmente para testar hipóteses especificas relacionadas ao papel de práticas culturais (DHANVATARI \& DIRKS, 1987) ou do vento (GOTTWALD et alii, 1993) na disseminação de patógenos. A grande limitação desse método é a unidirecionalidade da análise (CAMPBELL \& MADDEN, 1990). No entanto, em culturas plantadas em latices (citros ou café, por exemplo) os cálculos podem ser feitos na direção das linhas de plantio ou na perpendicular a elas, ampliando a quantidade de informação obtida.

A segunda classe de métodos de estudo do arranjo espacial (análises através de quadrats dispostos em malhas, transects ou aleatoriamente ao longo da área experimental) possui seis tipos de técnicas: mapas; distribuições discretas; indices de dispersão; variância de quadrados; autocorrelação espacial; ajuste à lei de Taylor.

\footnotetext{
${ }^{2}$ Unidade de amostragem, usualmente retângulos (equiláteros ou não), definidos por cada pesquisador (ODUM, 1988).

${ }^{3}$ Faixa ou linha de amostragem na qual os quadrats são definidos (ODUM, 1988).
} 


\section{i) Mapas}

O mapeamento (bi ou tridimensional) é uma técnica útil na visualização e discernimento de possiveis relaçōes entre os dados e variáveis, tais como fatores edáficos e fontes de inóculo. Nesse último caso, uma atenção especial é dada àquelas fontes localizadas fora da área avaliada. Em adição, áreas ou linhas isópatas podem ser construídas, denotando locais de mesmo nível de doença (BERGER \& LUKE, 1979; NOE \& BARKER, 1985).

ii) Ajuste a distribuições discretas

Parte-se do pressuposto de que a distribuição de freqüência dos dados pode indicar se as plantas doentes estariam aleatoriamente arranjadas ou agregadas. O ajuste das informações a distribuições discretas (Poisson, Beta Binomial, Binomial Negativa, etc.) informa apenas se há ou não aleatoriedade, não guardando qualquer informação sobre a posição relativa das unidades amostradas, não podendo também ser utilizado para dados de severidade. Mesmo assim, pode ser aplicado com sucesso se aliado a outras técnicas (MADDEN \& HUGHES, 1995). Geralmente, os parâmetros das distribuiçōes, como por exemplo o $k$ da Binomial Negativa (CAMPBELL \& MADDEN, 1990) e o $\theta$ da Beta Binomial (MADDEN \& HUGHES, 1995) são usados como índices de dispersão.

\section{iii) Índices de dispersão}

O cálculo de índices de dispersão (relação variância/média, índices de Lloyd, índice de Morisita, etc.) são baseados nas relações entre variância e média do conjunto de dados da área experimental e indicam regularidade (indice < 1), aleatoriedade (índice $=1$ ) ou agregação das medidas (índice $>1$ ) (UPTON \& FINGLETON, 1985). MADDEN \& HUGHES (1995) demonstraram que tais índices, que são baseados nas premissas da distribuição de Poisson (UPTON \& FINGLETON, 1985), não poderiam ser usados para dados de incidência como, por exemplo, proporção de plantas afetadas em dada área. Segundo aqueles pesquisadores, esse 
tipo de dado é melhor descrito pela função Binomial e, assim, os indices de dispersão devem ser outros. A utilização de índices de dispersão apropriados para dados de incidência vem, de forma gradual, ocupando espaço na literatura fitopatológica (GOTTWALD et alii, 1995; MADDEN et alii, 1995). Apesar de muito usados, os índices de dispersão têm a grande limitação, assim como o ajuste a distribuiçōes discretas, de não levarem em conta a posição relativa de cada medida. Ou seja, as mesmas informaçōes arranjadas de formas diversas numa mesma área experimental produziriam os mesmos resultados. Esse aspecto já foi bastante discutido e criticado por NICOT et alii (1984). Além disso, não podem ser usados para todos os tipos de dados (CAMPBELL \& MADDEN, 1990).

iv) Variância de quadrats

$\mathrm{Na}$ análise de variância de quadrats, esse parâmetro é calculado para os mesmos dados dispostos em quadrats múltiplos de $2(2 \times 2,4 \times 4,8 \times 8$, etc. $)$ e plotada em função do tamanho dos quadrats. $O$ tamanho do aglomerado de entidades doentes é dado pelo pico de variância. No entanto, é um método trabalhoso e com resultados pouco precisos, já que, se o pico for observado para o quadrat $8 \times 8$, significa que o tamanho médio do agrupamento está entre os quadrats $4 \times 4$ e $16 \times 16$ (UPTON \& FINGLETON, 1985), ou seja, entre 16 e 256 plantas.

v) Ajuste à lei de Taylor

Segundo TAYLOR (1961), a propriedade que populações têm de apresentar algum grau de agregação é altamente especifica. A partir de dados de distribuição espacial de diversas populações de uma espécie, pode-se relacionar linearmente o logaritmo da variância e o logaritmo da média $(\log$ var $=\log a+b . \log$ média ). Desse modo, TAYLOR (1961) considerou que os parâmetros da equação representam a caracteristica espacial de dada espécie. Mais especificamente, sugeriu o uso do parâmetro $b$ como indice de agregação: quando $b>1$ há agregação (tanto maior, quanto maior for o valor de $b$ ), quando $b=1$ há aleatoriedade e quando $b<1$, 
há regularidade. Ainda assim, segundo MADDEN \& HUGHES (1995), a interpretação de $b$ não deve ser separada da de $a$. Esses mesmos autores demonstraram ainda a inadequação da lei de Taylor para dados de incidência e propuseram uma modificação, atendendo à previsão de TAYLOR (1961) de que dados binários provavelmente necessitariam de tratamento estatístico especial (HUGHES \& MADDEN, 1992).

vi) Análise de autocorrelação espacial (AACE)

Segundo LEGENDRE (1993), autocorrelação espacial è uma característica geral de variáveis ecológicas e pode ser definida como a propriedade que os valores de variáveis aleatórias têm de, tomados dois a dois, em sítios separados por uma certa distância, serem mais similares (autocorrelação positiva) ou menos similares (autocorrelação negativa) que o esperado para pares de observações associadas ao acaso. A AACE é uma técnica potente, na medida em que pode trabalhar com dados discretos do tipo "contagem" ou com dados contínuos do tipo "área foliar afetada". MADDEN \& HUGHES (1995) alertam, entretanto, que para trabalhar com incidência, os dados precisam ser transformados de forma conveniente. Os resultados da AACE são expressos em intervalos de espaço (ie $\geq 1$ ) em que os valores dos dados mantêm relação uns com os outros, ou seja, até qual intervalo de espaço ie uma certa medida (número de lesões, por exemplo) numa posição $e$ tem relação com as medidas nas posições $e+i e$ em dadas direções (GOTTWALD et alii, 1992). Raciocínio semelhante é usado na análise de autocorrelação espaço-tempo (REYNOLDS et alii, 1988). Ao contrário das técnicas anteriores, e por considerar a posição das medidas, a AACE obtém informação não só do arranjo espacial dos dados, mas também da relação entre medidas. Pode-se, assim, identificar não apenas a agregação, mas em quais locais da área experimental ocorreu e direção preferencial, entre outros atributos. Outra técnica baseada na correlação espacial teve sua origem em prospecções geológicas (TRANGMAR et alii, 1985) e é conhecida como geoestatística, já tendo sido aplicada em fitopatologia (CHELLEMl et alii, 1988; CHELLEMl et alii, 1991). 
As análises através das medidas de distância entre plantas doentes formam a terceira classe de métodos de estudo de arranjo espacial. A maioria dessas análises considera que os indivíduos podem ocupar qualquer posição no continuum de uma área, o que não é verdade para a maioria das culturas agronômicas. Entretanto, CAMPBELL \& MADDEN (1990) afirmam que investigações mais extensas devem ser feitas antes de qualquer recomendação contra ou a favor de tais métodos.

Na citricultura, dois desses métodos já foram utilizados com sucesso por LLANOS (1981), ao estudar a distribuição espacial de plantas afetadas pelo Declínio, bem como por MARCUS et alii (1984), com relação à Tristeza. De todos eles, o mais usado tem sido o índice de Clark e Evans, aplicado por esses últimos autores.

Além dessas três classes reconhecidas, recentemente foi proposta uma metodologia (NELSON, 1996) para estudo de distribuição espacial de plantas doentes. Por essa nova técnica, o caráter espacial de uma epidemia pode ser descrito a partir dos caracteres dos focos de plantas afetadas. Assim, é calculado o número de focos, seu tamanho médio, máximo, forma aproximada e, também, seu grau de compactação. Segundo NELSON (1996), as variáveis obtidas podem ser usadas para testes de hipóteses ou usadas em conjunto a outras técnicas, para melhor entender o patossistema. Embora seja um método simples, de fácil uso e que fornece um número razoável de descritores para a epidemia, a sua viabilidade ainda não foi testada num grande número de patossistemas.

\subsection{Clorose Variegada dos Citros (CVC)}

\subsubsection{Sintomas}

Os sintomas da Clorose Variegada dos Citros manifestam-se apenas nos ramos, em folhas e nos frutos. As raízes não apresentam qualquer anormalidade (MALAVOLTA et alii, 1990). Inicialmente, pode-se encontrar apenas um ou poucos ramos atacados na parte média ou superior da planta, mas com o passar do tempo toda a árvore pode apresentar os sintomas típicos da anomalia. Plantas de viveiro ou 
de até 15 anos têm mostrado sintomas, os quais, nestas últimas, na maioria das vezes, ficam restritos a poucos ramos (LEE et alii, 1991). Os sintomas mais característicos são observados em folhas maduras e, segundo MACHADO et alii (1992), podem ser de três tipos:

i) clorose internerval típica de deficiência de zinco afetando todo o limbo;

ii) clorose pontuada de distribuição ao acaso, bastante parecida com picadas de insetos;

iii) clorose contínua e restrita a algumas áreas da folha.

No entanto, para LARANJEIRA (1996), em plantas muito afetadas pela CVC, é comum a presença de desequilíbrios nutricionais. Estes, porém, não se constituem em sintomas especificos ou fases do sintoma típico. Tipicamente, há também o desenvolvimento de bolsas de goma na face inferior do limbo que, ao romperem-se, produzem manchas amarronzadas. Segundo AMORIM et alii (1993b), os sintomas foliares podem ser caracterizados como manchas cloróticas esparsas, de formato irregular e localizados, majoritariamente, próximas às bordas do limbo (Figura 1). As plantas, quando muito afetadas, apresentam um aspecto de debilidade geral, denotado por coloração amarelada (Figura 2). É comum a ocorrência de subdesenvolvimento, assim como a presença de desfolha e morte de ramos ponteiros. Os ramos afetados têm, comumente, entre-nós encurtados não raro dando um aspecto "envassourado" ao ramo (Figura 3). Observa-se também que as gemas dos ramos afetados tendem a brotar com uma freqüência maior que o observado nos sadios. 


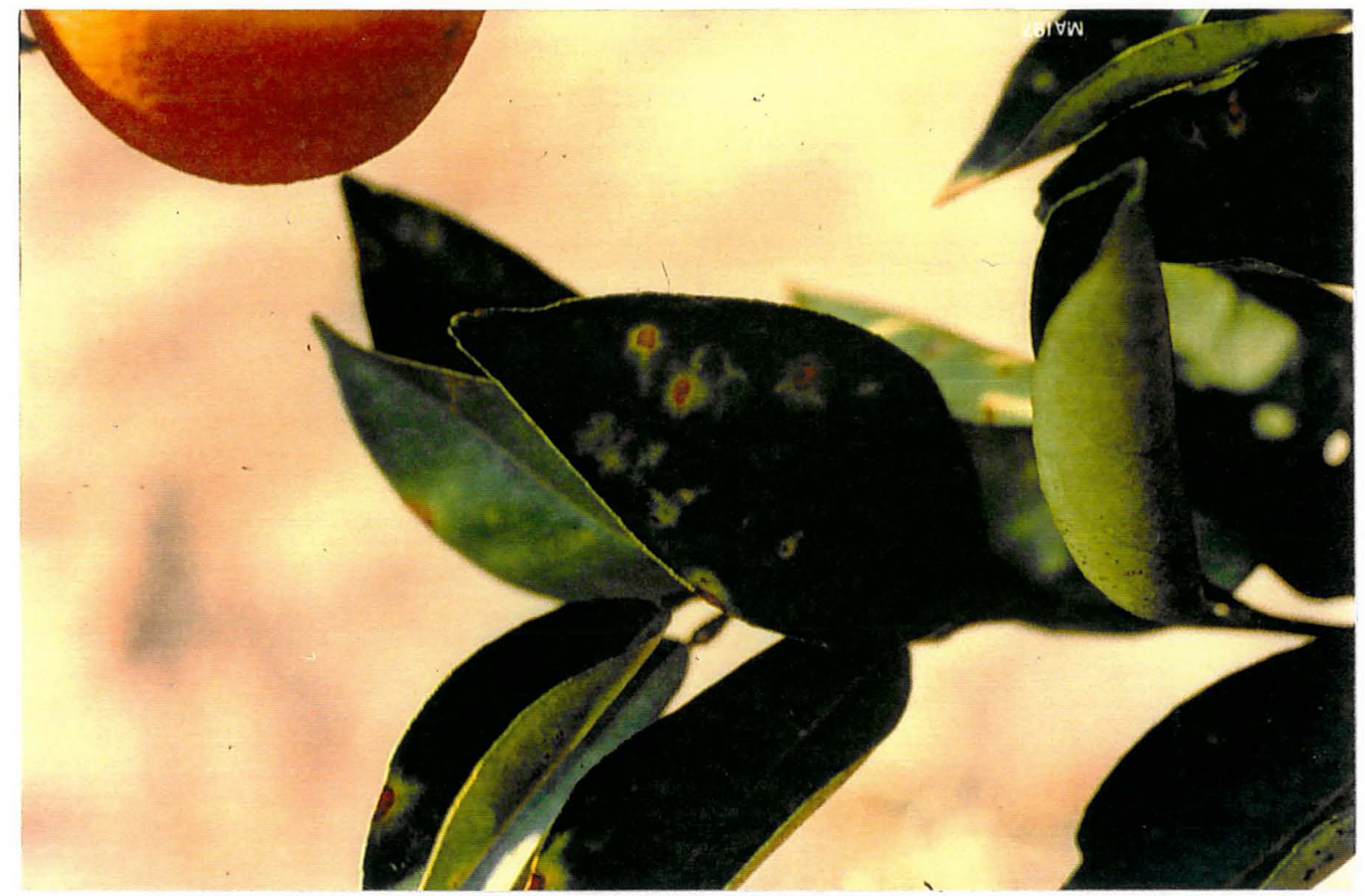

Figura 1 - Sintomas foliares de Clorose Variegada dos Citros (CVC)

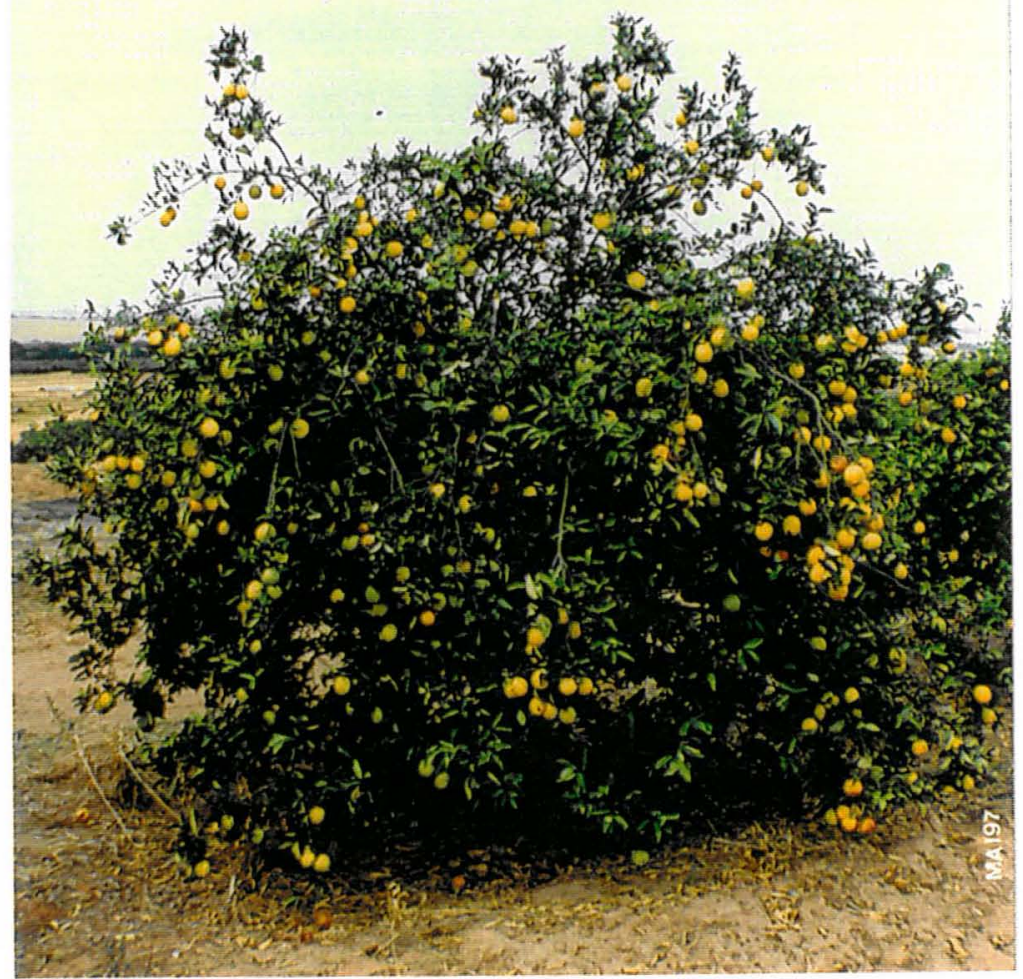

Figura 2 - Aspecto geral de planta afetada pela CVC. 


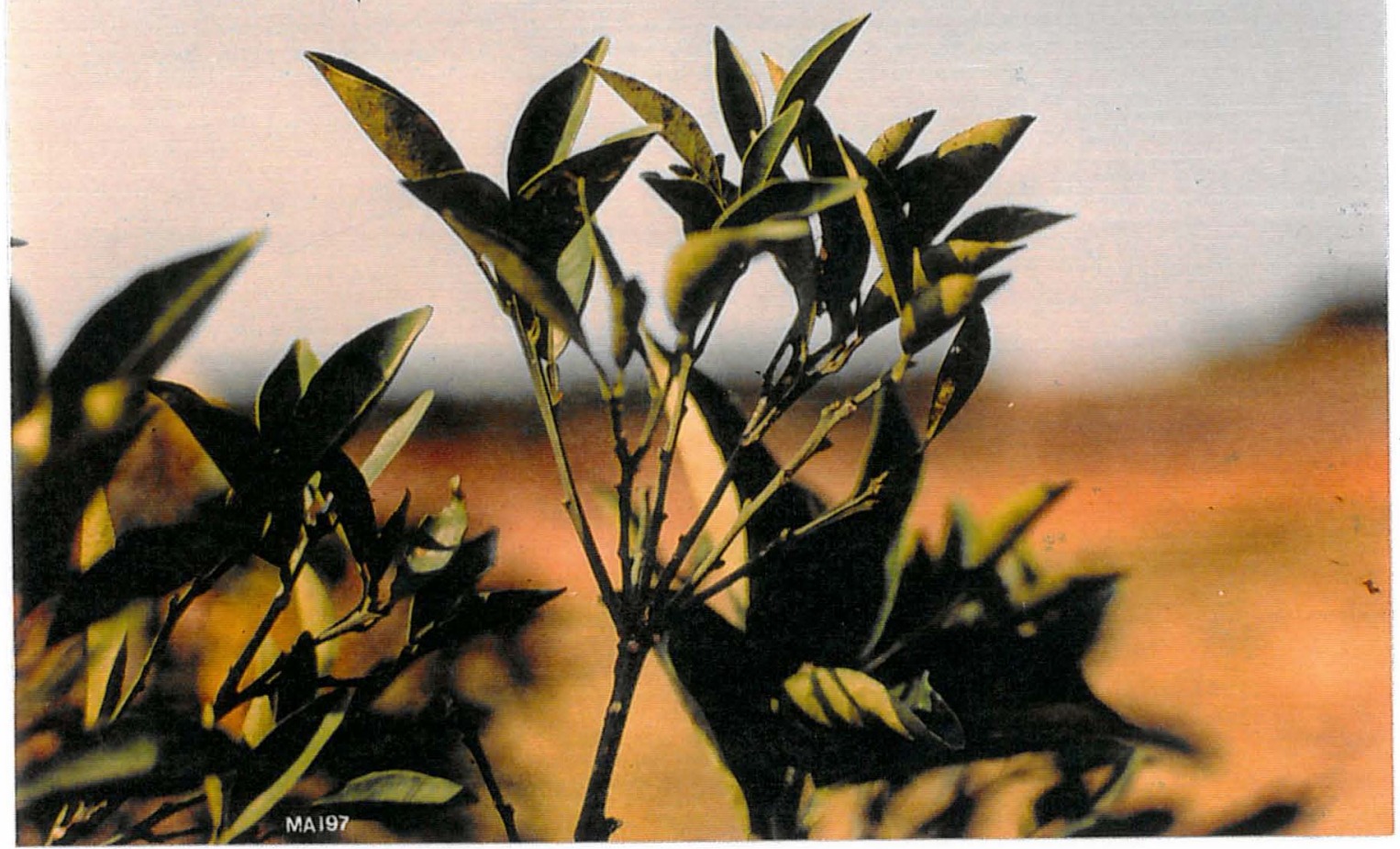

Figura 3 - Superbrotamento de ramos de planta afetada pela CVC.

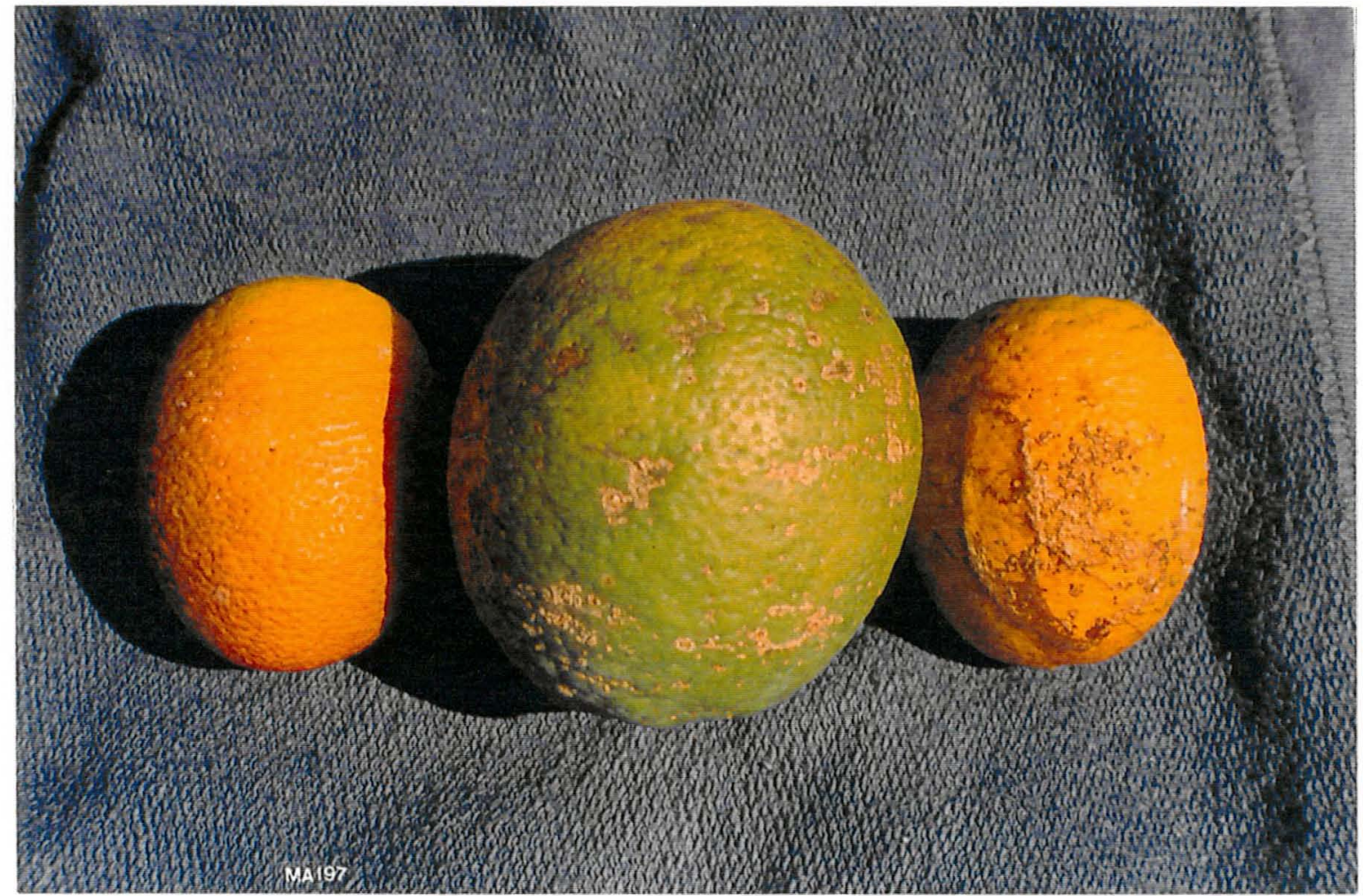

Figura 4 - Fruto de ramo sadio (centro) e frutos afetados pela CVC (laterais). 
Os frutos são pequenos, endurecidos, aparentam deficiência de potássio (Figura 4) e chegam a causar danos às máquinas de moagem das fábricas de suco concentrado. Amarelecimento precoce e lesōes de cor marrom-escura (tipo queimadura) também têm sido detectados (MACHADO et alii, 1992). Os sintomas nos frutos surgem após o aparecimento dos sintomas foliares e apenas nos ramos já afetados (LARANJEIRA, 1997). Segundo PALAZZO et alii (1991), nos dois primeiros meses de desenvolvimento, os frutos de ramos atacados apresentam a mesma taxa de crescimento de frutos de ramos não-sintomáticos; mês a mês, porém, a taxa para os frutos atacados diminui e, no sétimo mês, detecta-se uma diferença de 10 a $20 \mathrm{~mm}$ no diâmetro, a favor dos sadios. Adicionalmente, a casca se torna mais fina, facilitando a ocorrência de queimaduras de sol e a relação altura/largura dos frutos tende a aumentar (LARANJEIRA, 1997). Os frutos têm suas características organolépticas bastante afetadas. LARANJEIRA \& PALAZZO (1994) mostraram que o teor de sólidos solúveis e a acidez aumentam, parecendo ser este um efeito apenas de concentração, já que a quantidade de suco diminui. Como conseqüência, a produção total de sólidos solúveis é menor. Obviamente, essas características são bastante prejudiciais, tanto para a produção do suco de laranja, quanto para a comercialização dos frutos in natura. A produção é diminuída em termos de peso de fruto e número de frutos. PALAZZO \& CARVALHO (1992) relatam que plantas sadias de laranja Natal produziram entre 30 e $35 \%$ mais que plantas doentes da mesma variedade no município de Colina, SP.

\subsubsection{Etiologia}

A CVC afeta a absorção e a distribuição de certos nutrientes, em especial o zinco e o potássio, cujos teores foliares são muito reduzidos. Tal redução independe dos teores presentes no solo e de aplicações foliares de zinco ${ }^{4}$. MALAVOLTA et alii (1990) não conseguiram apontar o desarranjo nutricional como causa da doença. Da mesma forma, WUTSCHER et alii (1994) não conseguiram mostrar que excesso ou falta de elementos químicos eram causa da doença.

\footnotetext{
${ }^{4}$ Dr. José Antônio Quaggio, Seção de Fertilidade do Solo - IAC, comunicação pessoal, 1995.
} 
Em 1990 foi estabelecida uma associação, através de microscopia eletrônica, entre a CVC e uma bactéria gram-negativa limitada ao xilema: somente material sintomático continha o procarioto. Essa bactéria possui entre 1 e $4 \mu \mathrm{m}$ de comprimento por 0,25 a $0,50 \mu \mathrm{m}$ de diâmetro e apresenta parede celular crenulada com três camadas (externa; interna ou membrana citoplasmática; intermediária ou de peptidioglicanos). Segundo ROSSETI et alii (1990) e CHAGAS et alii (1992), essa bactéria, considerada por algum tempo um "organismo tipo rickettsia", foi identificada como $X$. fastidiosa. Outras características importantes do ponto de vista sistemático seriam a não-motilidade devido à falta de flagelos; a não-pigmentação; o fato de ser aeróbica e também crescer muito lentamente em meio de cultura (WELLS et alii, 1987). Ainda relacionando CVC com $X$. fastidiosa, estudos serológicos ("dotimmunobinding-assay") foram feitos com uso de anti-soro preparado contra as doenças de Pierce e da escaldadura de folhas da ameixeira, entre outras de mesma etiologia (BERETTA et alii, 1991). Os resultados foram positivos, indicando tratar-se de $X$. fastidiosa. A bactéria causadora da CVC foi isolada pela primeira vez no Brasil, por LEITE Jr. \& LEITE (1991).

Essa bactéria tem sido reportada como causadora de diversas doenças, tais como: doença de Pierce da videira; escaldadura das folhas da ameixeira e a doença "phony" do pessegueiro. Nessas espécies, a bactéria é sistêmica e a capacidade que tem de colonizar o hospedeiro e nele se espalhar foi correlacionada com sua patogenicidade (HOPKINS, 1989). Mais recentemente, os postulados de Koch foram cumpridos e foi estabelecido que $X$. fastidiosa é o agente causal da CVC (CHANG et alii,1993). Apesar disso, ainda estão em aberto as questões da existência de raças desta bactéria, da sua interação com o virus da Tristeza - onipresente em plantações paulistas (COSTA, 1956) - bem como do seu comportamento frente a fatores climáticos e nutricionais.

\subsubsection{Controle}

Experimentalmente, BERETTA et alii (1992) testaram o efeito da oxitetraciclina como agente bactericida, visando a remissão ou, pelo menos, um 
atraso no aparecimento dos sintomas. A remissão dos sintomas foi conseguida quando o solo foi encharcado com o produto e injetou-se a substância no tronco das plantas afetadas.

No município de Bebedouro, SP, vem sendo testada a utilização de poda sistemática de ramos afetados para o controle desta doença, com resultados até o momento satisfatórios (RODAS, 1994). No entanto, esta parece ser uma técnica bastante trabalhosa e não muito eficiente para plantas muito novas e já afetadas. Segundo GARCIA Jr. et alii (1995), plantas de 1,5 ano sintomáticas ou de 2 a 4 anos mas já com frutos miúdos devem ser erradicadas porque para elas a poda não tem funcionado a contento. É provável que isso ocorra devido à sistemicidade da bactéria em plantas infectadas precocemente ou há muito tempo.

Desde o surgimento da CVC, a preocupação com a sanidade das mudas cítricas tem aumentado. A produçāo de material propagativo de citros livre de patógenos $\mathrm{e}$, notadamente, livre de $X$. fastidiosa, teve impulso com a criação do primeiro protótipo de borbulheira coberta com telado anti-afídeos (CARVALHO \& LARANJEIRA, 1994).

Até o momento, não se conhece nenhuma variedade ou clone de laranja doce resistente a $X$. fastidiosa. Apesar disso, a variabilidade dentro desse grupo é bastante alta (LI et alii, 1996; LARANJEIRA et alii, 1996). Por enquanto, apenas a laranja Westin, nas condições de Mirassol, SP, apresentou-se promissora para ser utilizada num esquema de convivência com a CVC (LARANJEIRA et alii, 1996). Ainda dentro do grupo das laranjas doces, uma outra forma de se obter variedades tolerantes ou resistentes é através de seleção de plantas pouco afetadas ou assintomáticas em pomares altamente contaminados. Em São Paulo, vários grupos de trabalho já possuem plantas selecionadas, as quais, após testadas satisfatoriamente, poderão ser alternativas para o citricultor (AMARELINHO..., 1996). Mais importante, no entanto, foi a descoberta de híbridos altamente resistentes e muito promissores. O suco desse material pode ser utilizado em mistura com o suco de laranja, restando ainda a alternativa da fruta híbrida poder ser vendida para 0 
mercado de consumo in natura (LARANJEIRA et alii, 1997; TANGELOS..., 1996), o que beneficiaria principalmente o pequeno produtor.

\subsubsection{Epidemiologia da CVC}

\subsubsection{Disseminação}

As hipóteses para a dispersão de $X$. fastidiosa em citros são duas:

i) De fora para dentro do pomar, por meio de mudas infectadas e/ou cigarrinhas já portadoras após alimentação em pomares vizinhos infectados ou em hospedeiros alternativos da bactéria;

ii) Dentro de um mesmo pomar, por meio de cigarrinhas.

Hemípteros cicadelídeos conhecidos como cigarrinhas são presença constante em pomares da Flórida e têm sido apontados como vetores de $X$. fastidiosa naquelas condiçōes (BRLANSKY et alii, 1982). No Brasil, em levantamento datado de 1989, LEFÈVRE et alii (1989) relatam a presença constante de algumas espécies de cigarrinha em laranjais paulistas.

Segundo PURCELL et alii (1979), no patossistema da doença de Pierce da videira, até iniciar-se a fase adulta do inseto, a cada ecdise o cicadelídeo perde sua "carga bacteriana". No inseto adulto, após adquirir a bactéria, a cigarrinha a transmite por toda sua vida. Além disso, segundo evidências apontadas por PURCELL \& FINLAY (1979), o mecanismo de transmissão deve ser do tipo nãocirculativo, sem, no entanto, haver transmissão transovariana (AGRIOS, 1988).

No caso da CVC, existem evidências do envolvimento de insetos na disseminação de $X$. fastidiosa. ROSSETI et alii (1995) após três anos de observação, encontraram que mudas de laranja Natal plantadas em área com alta incidência de CVC apresentaram sintomas apenas quando não estavam protegidas por telado. Além disso, já havia sido constatada a presença da bactéria no aparelho bucal de diversas espécies de cigarrinhas em São Paulo, inclusive nas espécies mais abundantes (Acrogonia sp., Dilobopterus sp. e Oncometopia sp.) (ROBERTO et alii, 
1995). A transmissão da bactéria causadora da CVC pelas espécies de cigarrinhas mais abundantes foi determinada por LOPES et alii (1996). Após 6 meses da inoculação por meio de insetos contaminados, as primeiras plantas começaram a apresentar sintomas. A presença da bactéria foi confirmada por testes serológicos. Aparentemente, Dilobopterus costalimai é a espécie mais eficiente. Esse trabalho foi confirmado por ROBERTO et alii (1996).

Em diversas outras espécies de cigarrinhas já se detectou, serologicamente, a bactéria em seu aparelho bucal (TEBAR et alii, 1994). Esse fato sugere que a bactéria pode ser transmitida de forma ampla, na citricultura.

Até o momento, não se constatou a transmissão mecânica da $X$. fastidiosa através de instrumentos cortantes. Da mesma forma, não se conseguiu demonstrar a transmissão do patógeno por sementes (SUGIMORI et alii, 1995).

\subsubsection{Plantas hospedeiras}

O gênero Citrus é afetado quase como um todo, já que laranjas doces (Citrus sinensis), tangerinas (Citrus reticulata), tangores (Citrus reticulata $\mathrm{x}$ Citrus sinensis), tangelos (Citrus reticulata $\times$ Citrus paradisl) e lima ácida Taiti (Citrus latifolia) podem apresentar sintomas. Árvores de outros gêneros da familia Rutaceae e relacionados ao Citrus, como Fortunella e Poncirus, não se apresentam sintomáticas ou com a bactéria em seus tecidos em condições de transmissão natural (LARANJEIRA et alii, 1995).

$X$ fastidiosa pode ser encontrada em café (PARADELA FILHO et alii, 1995) e em diversas plantas daninhas, como guanxuma e capim pé-de-galinha (HARAKAVA et alii, 1994; TRAVENSOLO \& LEITE Jr., 1996). Entretanto, ainda não se sabe se os biótipos encontrados nesses hospedeiros podem causar problemas em citros. Também na Flórida já foi constatada a presença de $X$. fastidiosa em vegetais de ocorrência natural, parecendo ser esta uma situação bastante comum (HOPKINS \& ADLERZ, 1988). No Brasil, a bactéria àinda é encontrada em ameixeira (KITAJIMA 
et alii, 1981) mas, assim como para o café, não se sabe se pode ser patogênica também aos citros.

As laranjas doces são, aparentemente, hospedeiros mais suscetiveis de $X$. fastidiosa causadora da CVC, embora, dentro desse grupo de laranjas, existam diferenças bastante acentuadas em relação à suscetibilidade (LARANJEIRA et alii, 1995; LI et alii, 1996). Tangerinas e seus híbridos, como tangores ou tangelos, podem apresentar sintomas em condições de campo, embora numa intensidade bem menor que nas laranjas doces. Até o momento, esses sintomas foram constatados apenas em variedades não-comerciais (POMPEU Jr. et alii, 1994; LARANJEIRA et alii, 1996). Naquelas com maior valor econômico, como Ponkan, Cravo e Murcote, apenas constatou-se a presença da bactéria quando sobre-enxertadas em plantas de laranja doentes (MACHADO et alii, 1997). Em condições de transmissão natural, a bactéria nunca foi detectada nos tecidos dessas tangerinas ou nos da Mexirica (LARANJEIRA, 1997). Em lima ácida Taiti os sintomas só foram observados uma vez, em plantas locadas em pomar de laranja altamente afetado (BERETTA et alii, 1993).

Dentre as variedades utilizadas como porta-enxerto, apenas duas seleções de limão Rugoso foram constatadas como hospedeiras de $X$. fastidiosa (LARANJEIRA et alii, 1995). Todos os testes realizados com limão Cravo apontam-no como não-hospedeiro da bactéria (MACHADO et alii, 1993).

Além de plantas daninhas, café, tangerinas e híbridos, a ocorrência de outras possíveis fontes de inóculo de $X$. fastidiosa para citros é uma incógnita. No caso do pessegueiro, a ameixeira selvagem é considerada como reservatório da bactéria e pode ser fonte de inóculo (FRENCH, 1976). Já para a videira, tanto as plantas que margeiam as plantaçōes (em especial aquelas próximas a fontes de água) quanto ervas daninhas associadas à cultura podem hospedar não só a bactéria, mas também os seus vetores (RAJU et alii, 1980; HERNANDEZ-GARBOSA \& OCHOA-CORONA, 1994). 


\subsubsection{Aspectos temporais e espaciais}

Ainda não existem relatos completos sobre o progresso temporal da CVC. Entretanto, informes preliminares dão conta de uma evolução rápida na incidência e severidade de sintomas, em folhas de ramos marcados, no período entre a florada (setembro/outubro) e o final do verão (março) (PALAZZO \& CARVALHO, 1992). As autoras sugerem ainda que o maior progresso da CVC nessa época deve estar relacionado a elevações na temperatura, pluviosidade regular e surtos vegetativos. Por outro lado, GOTTWALD et alii (1993), avaliando incidência em plantas, concluiram que o progresso temporal da CVC ajusta-se ao modelo de Gompert. Além disso, concluiram também que, considerando a taxa aparente de infecção calculada, a incidência chegaria a 100\% entre 10 e 13 anos a partir do início da epidemia.

Em contraste, foi determinado que, para a doença de Pierce, o modelo que melhor explica o progresso da doença è o monomolecular (VAN DER PLANK, 1963), provavelmente por estarem as principais fontes de inóculo localizadas fora da área de plantio (PURCELL, 1974). Para outras doenças causadas pela mesma bactéria, essa é uma informação não-disponivel.

Embora existam muitos trabalhos envolvendo o estudo da distribuição espacial de doenças em plantas citricas (AUBERT et alii, 1984; MARCUS et alii, 1984; GOTTWALD et alii,1989a; 1989b; GOTTWALD \& GRAHAM, 1991; GOTTWALD et alii, 1992; AGOSTINI et alii, 1993; LARANJEIRA et alii, 1993; LARANJEIRA \& GUIRADO, 1994), e a Clorose Variegada dos Citros ter sido descoberta há quase dez anos, apenas uma investigação preliminar sobre 0 assunto foi tornada de conhecimento geral.

Segundo GOTTWALD et alii (1993), estudando área no municipio de Colina, SP, o arranjo e a dinâmica espacial das plantas doentes sugerem associação com vetores de limitada dispersão aérea. Entretanto, alguns procedimentos utilizados nesse trabalho para caracterizar a dinâmica espacial não são os mais adequados, considerando-se as recomendações de MADDEN \& HUGHES (1995) em relação a esse tipo de estudo. Além disso, como os próprios autores reconhecem, esse estudo 
é baseado em dados de uma única epidemia, podendo ser considerado preliminar. É também o único conjunto de dados epidemiológicos quantitativos para essa doença (GOTTWALD et alii, 1993). NELSON (1996), usando esses mesmos dados e trabalhando com a descrição da estrutura dos focos, observou que seu número tendeu a aumentar até quando a incidência da doença se situou em cerca de $25 \%$. A partir daí, houve coalescência dos focos. Segundo o autor, a compactação dos focos inicialmente aumentou de acordo com o aumento na incidência. Após o início da coalescência, os focos tenderam a ficar menos compactos. NELSON (1996) observou ainda que os focos têm formatos isodiamétricos e que os tamanhos mais freqüentes ficaram entre 1 e 4 plantas. 


\section{MATERIAL E MÉTODOS}

\subsection{Seleção e caracterização das áreas}

A escolhas das áreas foi feita levando-se em conta os seguintes critérios, em ordem de importância:

i) plantios de laranjas doces, preferencialmente Pera, enxertadas em limão Cravo;

ii) idades variando de 1 a 3 anos;

iii) região Norte de São Paulo;

iv) ausência de linhas incompletas ou curvas;

v) baixa incidência de CVC no talhão.

Com a observância desses fatores pretendeu-se estudar a doença nas variedades mais suscetiveis, em idades aparentemente mais propicias ao seu desenvolvimento (DE NEGRI \& GARCIA Jr., 1993), abrangendo a maior parte do tempo das epidemias, em região bastante afetada pela CVC, segundo diagnóstico previamente realizado, porém fácil para acesso e estabelecimento de base de trabalho. Além disso, a ausência de linhas incompletas ou curvas facilitou sobremaneira a execução das análises estatísticas necessárias. Assim, foram selecionados nove talhões codificados e descritos a seguir:

SJ 01 (Figura 5): Fazenda São José, Bebedouro, SP. Laranja Hamlin, plantio em junho de 1993, espaçamento 7,5 x 4,5 metros, com 2768 plantas em 36 linhas em alinhamento Leste/Oeste, margeado por pasto, plantio de laranja Natal da mesma idade e rodovia estadual. Esse talhão foi subdividido em 5 áreas homogêneas 
(denominadas SJ 01 - 1 a 5), já que o número de plantas por linha de plantio era muito desigual. A SJ 01-1 correspondeu à porção média do talhão, com 24 linhas de 60 plantas cada. A SJ 01-2 foi localizada após a SJ 01-3 na porção do talhão mais próxima da estrada interna da fazenda, com 11 linhas de 15 plantas cada. A SJ 01-3 ficou entre a SJ 01-1 e a SJ 01-2, com 20 linhas de 9 plantas cada. A SJ 01-4 ficou posicionada entre a SJ 01-1 e o pasto, com 8 linhas de 27 plantas cada. A SJ 01-5 ficou na porção do talhão mais próxima à rodovia estadual, e contou com 16 linhas de 14 plantas cada.

SJ 67 (Figura 6): Fazenda São José, Bebedouro, SP. Laranja Pera, plantio em junho de 1992, espaçamento $8 \times 3$ metros. Parte inicial e uniforme do talhão, com 2880 plantas em 18 linhas em alinhamento Leste/Oeste. Margeado pelo talhão SJ 71, plantio de laranja Natal da mesma idade que o SJ 71 e talhão de laranja Pera com mais de 10 anos de idade.

SJ 71 (Figura 6): Fazenda São José, Bebedouro, SP. Laranja Pera, plantio em maio de 1991, espaçamento $8 \times 4$ metros. 3960 plantas em 33 linhas em alinhamento Leste/Oeste. Margeado pelos talhões SJ 67 e SJ 75, plantio de laranja Natal de mesma idade e talhão de laranja doce com mais de 10 anos de idade (posteriormente arrancado e substituído por cultura de milho - 94/95 - e soja - 95/96 - nos verões; em outras épocas a área foi deixada "no limpo").

SJ 73 (Figura 6): Fazenda São José, Bebedouro, SP. Laranja Natal, plantio em julho de 1993, espaçamento 7,5 x 4,5 metros. Porção inicial do talhão, com 1440 plantas em 18 linhas em alinhamento Leste/Oeste. Margeado pelos talhões SJ 75, plantio de laranja Natal de mesma idade do talhão SJ 71 e talhão de tangerina Ponkan de propriedade vizinha.

SJ 75 (Figura 6): Fazenda São José, Bebedouro, SP. Laranja Pera, plantio em agosto de 1993, espaçamento 7,5 3 metros. Porção inicial e homogênea do talhão, com 2880 plantas em 18 linhas em alinhamento Leste/Oeste. Margeado pelos talhões SJ 71 e SJ 73 e talhão de laranja Pera com mais de 10 anos de idade (posteriormente arrancado e substituído por cultura de milho - 94/95 - e soja - 95/96 - nos verões; em outras épocas a área foi deixada "no limpo"). 
SJ 83 (Figura 5): Fazenda São José, Bebedouro, SP. Laranja Hamlin, plantio em março de 1994, espaçamento 8 × 5 metros. 584 plantas em 14 linhas em alinhamento Leste/Oeste. Margeado por pasto, plantio de laranja Natal de mesma idade que o SJ 01 e mata próxima a um pequeno regato.

CQH (Figura 7): Fazenda Carro Queimado, Colina, SP. Laranja Hamlin, plantio em dezembro de 1993, espaçamento 8 × 5 metros. Porção final e homogênea do talhão, com 3300 plantas em 33 linhas em alinhamento Sudeste/Noroeste. Margeado pelo talhão CQN, por talhão de laranja Valência com 26 anos de idade e por rodovia estadual.

CQN (Figura 7): Fazenda Carro Queimado, Colina, SP. Laranja Natal, plantio em dezembro de 1993, espaçamento $8 \times 5$ metros, com 1180 plantas em 36 linhas em alinhamento Sudeste/Noroeste. Margeado pelo talhão $\mathrm{CQH}$, por um talhão de laranja Natal com 18 anos de idade e talhão de 26 anos de laranja Valência.

CQP (Figura 8): Fazenda Carro Queimado, Colina, SP. Laranja Pera, plantio em 1991, espaçamento $7 \times 4$ metros. Porção inicial e homogênea do talhão, com 1050 plantas em 21 linhas em alinhamento Sudoeste/Nordeste. Margeado por talhão 16 anos de idade de laranja Hamlin, por pomares recém-implantados de propriedade vizinha e por plantio de laranja Natal estabelecido nas mesmas condições do CQP e posteriormente arrancado devido a alta incidência de CVC.

Para os talhões da fazenda Carro Queimado houve aplicação de Aldicarb no primeiro ano de plantio. Nos anos subseqüentes, os tratos fitossanitários só se fizeram necessários para o controle de ácaros e plantas daninhas, não tendo sido aplicados inseticidas de amplo espectro de ação. As adubações foram feitas com Nitrocálcio, em duas aplicações anuais, a primeira entre setembro e outubro e a segunda entre janeiro e fevereiro de cada ano. Na fazenda São José, os tratos foram basicamente os mesmos da outra propriedade. As adubações foram realizadas sempre em duas parcelas, a primeira em novembro e a segunda em março de cada ano. Aplicou-se Nitrocálcio e formulações NPK. As pulverizações foram basicamente de acaricidas. Aplicações ocasionais de inseticidas fosforados para controle de cochonilhas foram realizadas no SJ 67 e SJ 01, no inverno de 1995. 
A localização dos municípios de Colina, Bebedouro e Piracicaba, no Estado de São Paulo, e a posição relativa de cada Divisão Regional Agrícola considerada estão apresentadas na Figura 9.

\subsection{Avaliações}

Nas áreas da fazenda São José as avaliações foram iniciadas em julho de 1994, com estudos exploratórios. A partir de setembro de 1994, os levantamentos foram feitos de dois em dois meses para todas as áreas, até março de 1996. As avaliações programadas para julho de 1995 não puderam ser feitas nos talhões SJ 73 e SJ 83.

Na fazenda Carro Queimado, os estudos exploratórios foram feitos em novembro de 1994, os levantamentos iniciados em janeiro de 1995 e realizados de dois em dois meses, com exceção dos programados para maio e julho de 1995, nos talhões CQN e CQP, e o de maio de 1995, no talhão CQH.

As avaliações, visuais e baseadas em sintomas foliares e nos frutos, foram feitas em todas as épocas, sempre pelas mesmas pessoas. Eram três, cada uma com pelo menos um ano de experiência na identificação de plantas doentes, no campo. As dúvidas foram esclarecidas com coleta de amostras e realização de teste serológico "dot immunobinding assay", segundo LEE et alii (1992). O mapeamento da área foi feito a partir dos dados binários (presença ou ausência de sintomas) anotados para cada planta. A cada levantamento, as novas plantas sintomáticas foram adicionadas aos mapas anteriores, obtendo-se assim o número acumulado de plantas doentes e a sua posição. Os mapas básicos de cada área foram confeccionados em planilha Quattro Pro, versão Windows. 


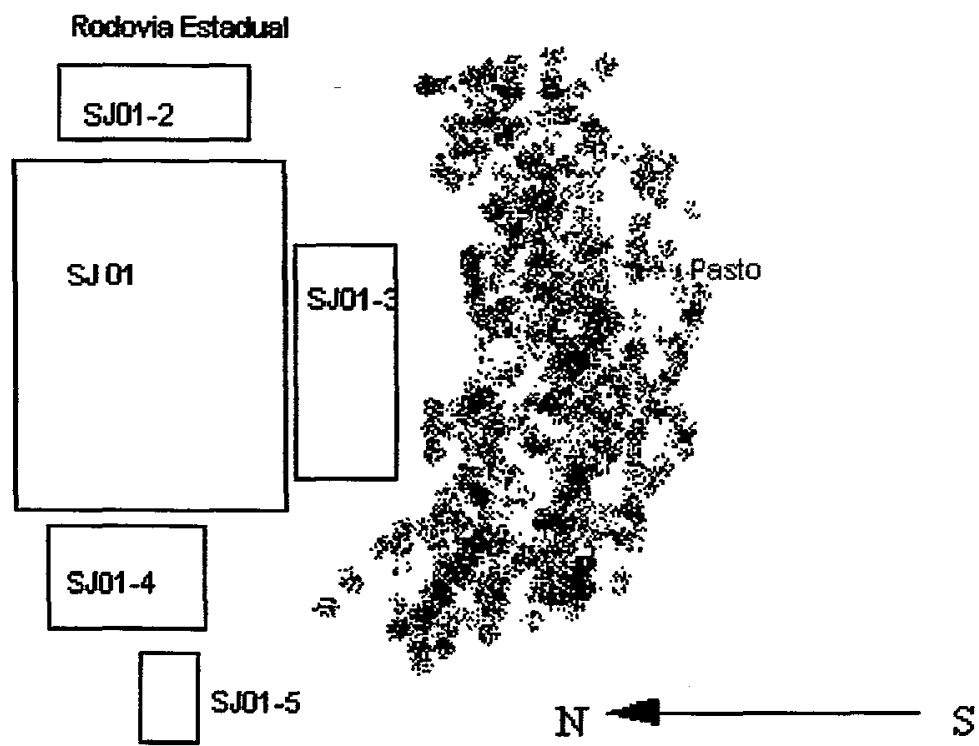

Estrada interna da fazenda
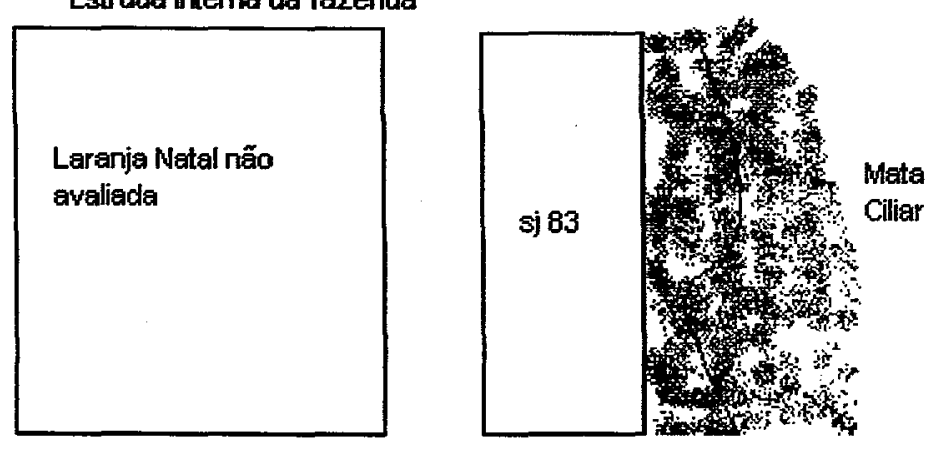

Figura 5 - Mapa de localização dos talhões SJ 01, SJ 01-2, SJ 01-3, SJ 01-4, SJ 01-5 e SJ 83, na fazenda São José, em Bebedouro, SP. 

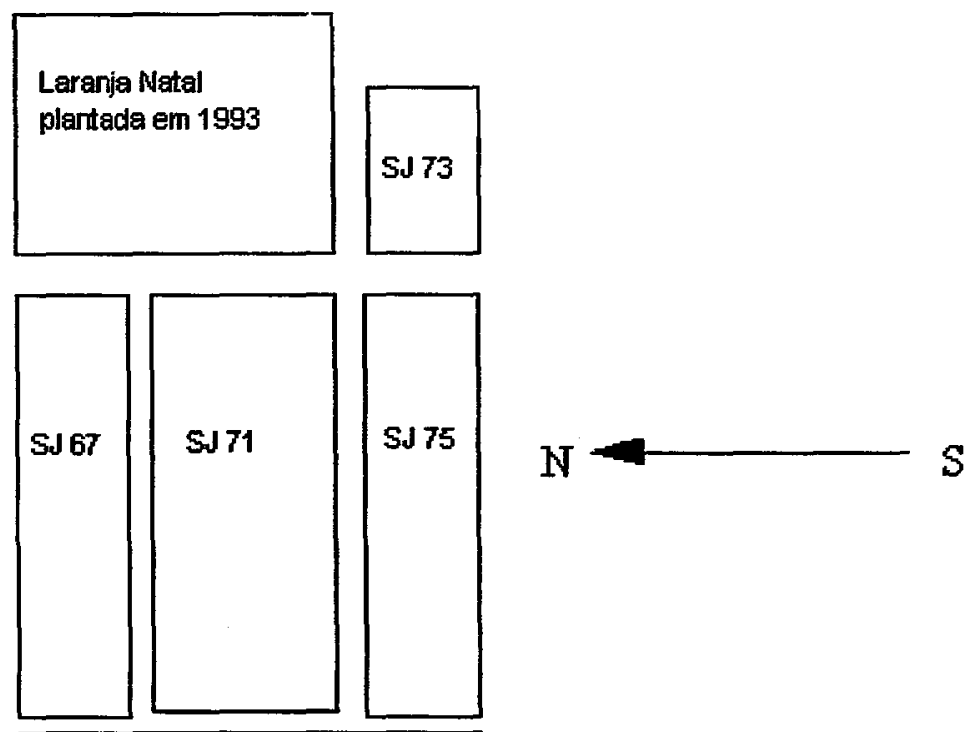

Laranja Pera com mais de 10 anos

Figura 6 - Mapa de localização dos talhões SJ 73, SJ 67, SJ 71 e SJ 75, na fazenda São José, em Bebedouro, SP. 
Roclowia estactua

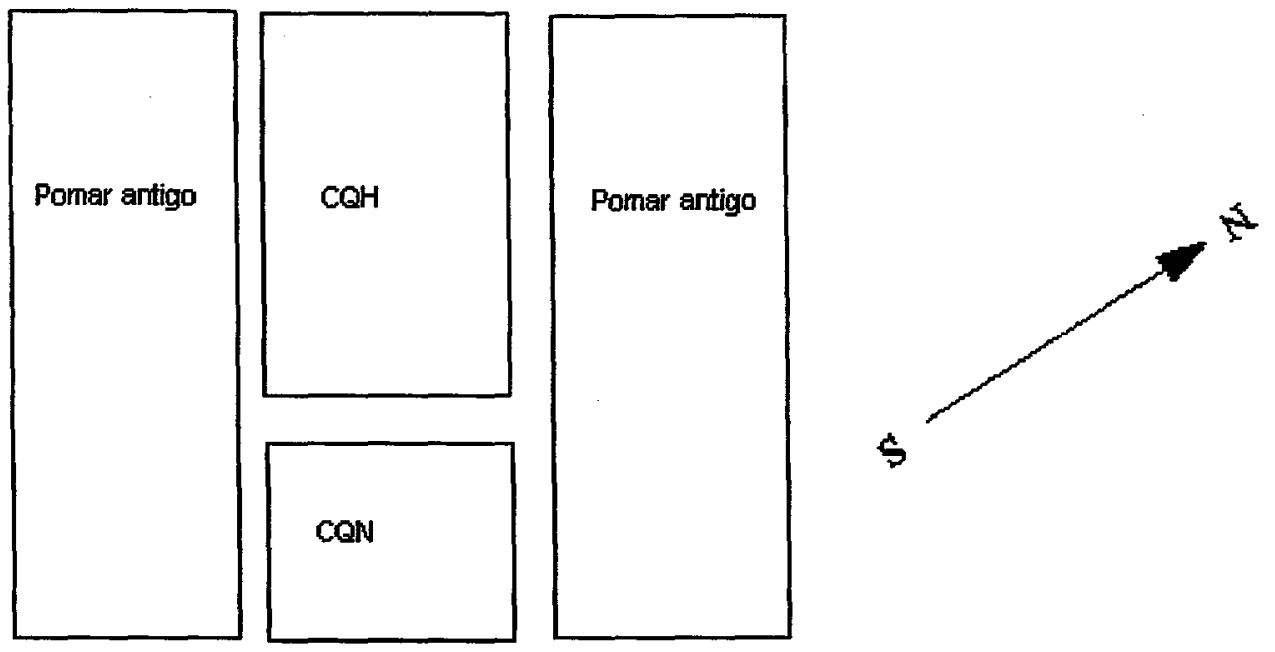

Pomar de mesma idade do CON

Figura 7 - Mapa de localização dos talhões CQH e CQN, na fazenda carro Queimado, em Colina, SP. 


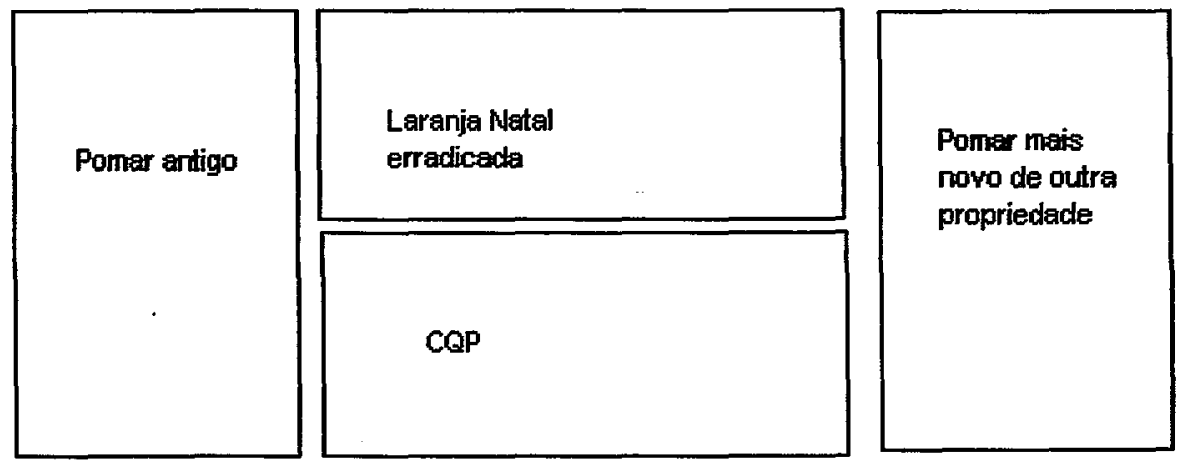

Pomar mais novo de outra propriedade

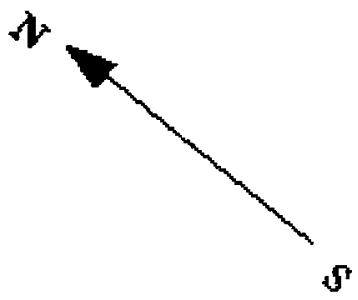

Figura 8 - Mapa de localização do talhão CQP, na fazenda Carro Queimado, em Colina, SP. 


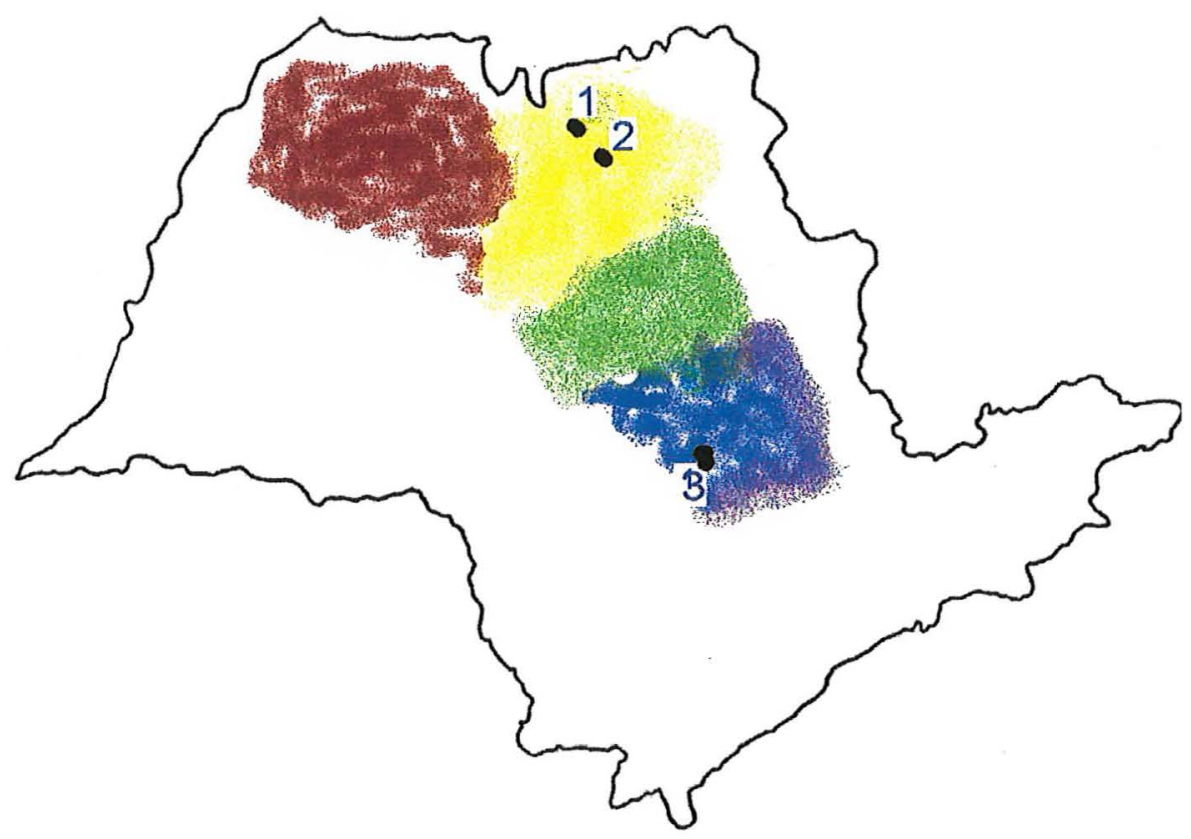

Figura 9 - Posição relativa dos municípios de Colina (1), Bebedouro (2) e Piracicaba (3) em relação às DIRAs de São José do Rio Preto (vermelho), Barretos (amarelo), São Carlos (verde) e Campinas (azul), no Estado de São Paulo. 


\subsection{Ajuste de modelos de progresso temporal aos dados obtidos}

Com base nos formatos das curvas de progresso obtidas, foram escolhidos 6 modelos (HAU et alii, 1993) a serem ajustados aos dados, generalizações de modelos amplamente utilizados para análise de epidemias em fitopatologia (BERGAMIN FILHO \& AMORIM, 1996):

- Monomolecular de 4 parâmetros:

$$
y(t)=p 1\left(1-\exp -\left(p 2+p 3 t+p 4 t^{2}+p 5^{2} t^{3} / 3 p 3\right)\right)
$$

- Monomolecular com 5 parâmetros :

$$
y(t)=p 1\left(1-\exp -\left(p 2+p 3 t+p 4 t^{2}+p 5 t^{3}\right)\right)
$$

- Gompertz com 4 parâmetros :

$$
y(t)=p 1 \exp -\left(-\exp -\left(p 2+p 3 t+p 4 t^{2}+p 5^{2} t^{3} / 3 p 3\right)\right)
$$

- Gompertz com 5 parâmetros:

$$
y(t)=p 1 \exp -\left(-\exp -\left(p 2+p 3 t+p 4 t^{2}+p 5 t^{3}\right)\right)
$$

- Logístico com 4 parâmetros:

$$
y(t)=p 1 /\left(1+\exp -\left(p 2+p 3 t+p 4 t^{2}+p 5^{2} t^{3} / 3 p 3\right)\right)
$$

- Logístico com 5 parâmetros:

$$
y(t)=p 1 /\left(1+\exp -\left(p 2+p 3 t+p 4 t^{2}+p 5 t^{3}\right)\right)
$$

Para essas equações, considera-se que:

$y(t)=$ proporção de plantas afetadas no tempo $t$

$t=$ tempo em meses

$p 1$ = proporção de plantas afetadas para a assíntota estimada

$\exp =$ base do logaritmo neperiano

$p 2=\ln \left(y\left(t_{0}\right)\right)$

$p 3 ; p 4$ e $p 5=$ parâmetros da taxa de progresso da doença 
Os dados foram analisados por meio de regressão não-linear com o utilitário STATISTICA 5.0. A ponderação, necessária para dados de incidência, foi feita através de variável calculada a partir dos valores originais e do valor do parâmetro $b$ da lei de Taylor modificada (MADDEN \& HUGHES, 1995). Para $b=1$ e $1<b<2$ as funçōes de transformação dos dados são respectivamente:

$z=\arcsin \left(y^{0,5}\right)$

$z=b\left(1,62+4,71 y-4,32 y^{2}+2,55 y^{4}\right)-1,62$

onde $y$ é a proporção de plantas afetadas em cada tempo $t$.

A regressão não-linear foi feita através do método Quasi-Newton, que estima assintoticamente as derivadas de segunda ordem (parciais) da função de perda $\left(\right.$ perda $=\left(\text { observado }- \text { previsto }^{2}\right)^{2}$ e as usa para determinar o movimento dos parâmetros de iteração a iteração.

A escolha do melhor modelo foi feita com base no coeficiente de determinação entre valores observados e valores previstos, na existência ou não de padrōes, no gráfico de resíduos versus valores previstos (CAMPBELL \& MADDEN, 1990) e na adequação dos valores previstos para o parâmetro $p 1$. Para o coeficiente de determinação, consideraram-se valores bons quando acima de 0,950 e excelentes quando excederam 0,980 . O modelo com coeficiente de determinação bom ou excelente foi aceito como apropriado apenas quando seu gráfico de resíduos versus valores previstos não apresentava padrões detectáveis e sua estimativa para o parâmetro $p 1$ não foi inferior ao último valor observado nem superior a 1.

A partir das equações estabelecidas para cada área, foi possivel calcular a taxa média de progresso da doença (r); a taxa de progresso da doença por épocas do ano $\left(r_{s}\right)$; os pontos de derivada dy/dt para cada tempo t e o ponto de $r$ mínimo.

As taxas médias ( $r$ ) foram calculadas a partir da equação deduzida por HAU et alii (1993) para os modelos generalizados de 5 parâmetros : 


$$
r\left(t_{f}-t_{i}\right)=\left[p 3\left(t_{f}-t_{i}\right)+p 4\left(t_{f}{ }^{2}-t_{i}{ }^{2}\right)+p 5\left(t_{f}{ }^{3}-t_{i}{ }^{3}\right)\right] /\left(t_{f}-t_{i}\right)
$$

onde $t_{f}$ é o tempo da última avaliação no campo e $t_{i}$ é o tempo da primeira. Por meio dessas mesmas equações foram calculadas as taxas $\left(r_{s}\right)$ para os períodos desejados, ou seja, as primaveras de 1994 e 1995, o outono e o inverno de 1995 e os verões de $1994 / 1995$ e de 1995/1996. Nesse caso, as diferenças entre $t_{f} e t_{\text {f }}$ foram obtidas pelas diferenças, em meses, entre solstícios e equinócios.

A derivada de cada curva de progresso, estimada a partir do modelo generalizado escolhido, foi calculada por :

$d y / d t=\left[y\left(t_{f}\right)-y\left(t_{f}\right)\right] /\left[t_{r}-t_{f}\right]$

O tempo entre duas ondas de progresso consecutivas, ou seja, o período de ocorrência da menor taxa de progresso, foi calculado por meio da função descrita por HAU et alii (1993):

$$
t_{0}=-p 4 /(3 p 5)
$$

\subsection{Quantificação da heterogeneidade espacial de plantas afetadas}

\subsubsection{Análise de seqüências ordinárias (ASO)}

Para cada talhão e para a sub-área SJ 01-4, em cada avaliação, foi calculado o percentual de linhas de plantio com agrupamento significativo de plantas doentes. Para as sub-áreas SJ 01-2, SJ 01-3 e SJ 01-5 a ASO foi realizada considerando-se que uma linha era a continuação da anterior (CAMPBELL \& MADDEN, 1990). Para esse estudo foram seguidas as definições e diretrizes de GIBBONS (1976), MADDEN et alii (1982) e VAN DER PLANK (1946), citado por MADDEN et alii (1982). Segundo o primeiro, "Em uma seqüência de dois ou mais tipos de símbolo, uma seqüência ordinária é definida como uma sucessão de um ou mais símbolos idênticos, que são seguidos e precedidos por um símbolo diferente ou nenhum símbolo" (GIBBONS, 1976). Assim, se tivermos um conjunto DDSSSDSDSDSSSDDDD, em que D represente uma planta doente e $S$, uma sadia,

\footnotetext{
${ }^{5}$ VAN DER PLANK, J.E. A method for estimating the number of random groups of adjacent diseased plants in a homogeneous field. Trans. R. Soc. S. Africa 31: 269 - 278, 1946.
} 
podemos dizer que esse conjunto possui 9 seqüências ordinárias. Para essa análise, a hipótese nula foi a de que um dado conjunto ordenado de símbolos (plantas infectadas) está distribuido de forma aleatória. A hipótese alternativa foi a de que as plantas infectadas estão agrupadas (MADDEN et alii, 1982). Sob a hipótese de aleatoriedade, o número esperado $(\mathrm{E})$ de seqũências ordinárias $(\mathrm{SO})$, o desvio padrão de SO ( $s_{s o}$ ) e o SO padronizado ( Zso) são obtidos, respectivamente, por:

$E(S O)=1+2 m(N-m) / N$

$s_{\mathrm{so}}=\left(2 \cdot m(N-m)[2 m(N-m)-N] /\left[N^{2}(N-1)\right]\right)$

$Z s o=[S O+0,5-E(S O)] / s_{s o}$

Nessas equaçōes $m$ é o número observado de plantas doentes e $N$ é o número total de plantas na linha.

Quanto mais agrupadas estiverem as plantas infectadas, mais negativo será o valor de Zso. As linhas ou sub-áreas foram consideradas com agrupamento de plantas com CVC, ao nivel de $5 \%$ de significância, se o valor de Zso foi igual ou inferior a -1,64. A premissa básica para o uso de tal análise foi a de que agrupamento significativo de plantas afetadas indica que o patógeno está se disseminando predominantemente de planta a planta, considerando que as observaçōes foram feitas em áreas homogêneas, segundo VAN DER PLANK (1946), citado por MADDEN et alii (1982).

\subsubsection{Vizinho mais próximo e distância entre plantas afetadas}

A análise de vizinho mais próximo foi utilizada calculando-se o índice de Clark e Evans (CE), corrigido para seguir a distribuição Normal (RIPLEY, 1979), e as distâncias entre plantas doentes foram calculadas segundo MARCUS et alii (1984). De acordo com RIPLEY (1979) e CAMPBELL \& MADDEN (1990), esse indice compara a distância média $\left(d_{m}\right)$ observada entre unidades (plantas doentes) com a distância média esperada $\left(E\left(d_{m}\right)\right.$ ) para uma dada área de $A \mathrm{~m}^{2} ; P \mathrm{~m}$ de perímetro e $N$ plantas no total. Assim: 


$$
C E=\left[d_{m}-E\left(d_{m}\right)\right] / \sqrt{\operatorname{var}\left(d_{m}\right)}
$$

sendo que $\mathrm{E}\left(\mathrm{d}_{\mathrm{m}}\right)=0,5 \sqrt{(A / N)}+(0,514+0,412 / \sqrt{N}) \mathrm{P} / \mathrm{N}$

$\operatorname{var}\left(\mathrm{d}_{\mathrm{m}}\right)=0,070 \mathrm{~A} / \mathrm{N}^{2}+0,037 \mathrm{P} \sqrt{A} / \sqrt{N^{5 / 2}}$

Quando $C E \leq-1,64$ considerou-se que as plantas doentes estavam agregadas ao nivel de $5 \%$ de significância; se, por outro lado, $C E \geq 1,64$ as plantas doentes foram tidas como regularmente distribuídas no talhão. Quando da ocorrência de valores do domínio $-1,64<C E<1,64$, considerou-se que a distribuição das plantas não diferiu da aleatoriedade.

Para a avaliação correspondente à primeira "assíntota" do progresso em duplo sigmóide, em cada talhão, foram calculadas as distâncias mais frequentes entre plantas doentes. Também foi obtida a distância média geral, considerando-se a distância média entre plantas doentes de todas as áreas. A primeira "assíntota" foi definida como a avaliação correspondente ao primeiro valor nulo assumido pela derivada de segunda ordem da curva estimada de progresso da doença de cada talhão.

\subsection{3. Índice de dispersão e aplicação da lei de Taylor modificada}

\subsubsection{Divisão das áreas e cálculo de $\mathrm{p}$}

As áreas SJ 01, SJ 67, SJ 71, SJ 73, SJ 75 e CQH foram divididas em retângulos de 3 linhas $\times 5$ plantas, totalizando 96 quadrats para SJ 01 e SJ 73, 264 quadrats para SJ 71, 192 quadrats para SJ 67 e SJ 75 e 220 quadrats para CQH. Para cada quadrat foi determinada a proporção de plantas afetadas em cada avaliação e calculada a incidência da doença na área. Essa variável foi representada por $p$ e pode ser definida como uma estimativa da probabilidade de uma planta estar doente (MADDEN \& HUGHES, 1995). Foi obtida por meio da equação :

$\mathrm{p}=\Sigma \mathrm{X}_{i} / \mathrm{nN}$ 
onde $\Sigma X_{i}$ è o somatório do número de plantas doentes em cada quadrat $i, n$ é o número de plantas em cada quadrat e $N$ é o número total de quadrats em cada área. Esses dados foram a base para o estudo da lei de Taylor modificada, para o cálculo do índice de dispersão e para o estudo de áreas isópatas.

\subsubsection{Aplicação da lei de Taylor modificada (HUGHES \& MADDEN, 1992)}

Para cada avaliação em cada área e para o conjunto de quadrats amostrados foi calculada a variância observada ( $V_{\text {obss }}$ ) e a variância binomial esperada $\left(v_{\text {bin }}\right)$. Sob a hipótese de aleatoriedade, e para incidência em proporção de plantas doentes, foram utilizadas as seguintes equações, cujos parâmetros foram definidos no item anterior (HUGHES et alii, 1996):

$v_{o b s}=\Sigma\left(X_{i}-n p\right)^{2} / n^{2}(N-1)$

$v_{b i n}=p(1-p) / n$

A lei de Taylor modificada (LTM) relaciona, por meio de polinômio do primeiro grau, a variância observada e a variância esperada para uma distribuição aleatória. Como os dados foram expressos em incidência, a distribuição binomial é a que melhor descreve esses dados numa condição de aleatoriedade (MADDEN \& HUGHES, 1995). Assim:

$\log \left(v_{\text {bin }}\right)=\log (A)+b \log \left(v_{\text {obs }}\right)$

em que $A$ e $b$ são parâmetros.

As regressões foram feitas por meio do método dos quadrados mínimos, utilizando-se o utilitário STATISTICA 5.0. Considerou-se como variável independente o logaritmo das variâncias binomiais estimadas para cada avaliação e como variável dependente, o logaritmo das variâncias observadas. Da mesma forma, foi aplicada a regressão para os dados de todas as áreas e avaliaçōes, em conjunto. A significância das relações entre $\log \left(v_{b i n}\right)$ e $\log \left(v_{o b s}\right)$ foi determinada pelo teste $F$ e a adequação do ajuste do modelo aos dados foi determinada por meio dos valores 
dos coeficientes de determinação $R^{2}$ e dos padrões de distribuição dos residuos, em gráficos de resíduos versus valores previstos de $\log \left(v_{\text {bin }}\right)$ (MADDEN et alii, 1995).

A normalidade dos residuos foi testada de acordo com a técnica de LOONEY \& GULLEDGE Jr. (1985). Essa técnica compara, através de regressão linear, os valores observados com valores nāo-normais, gerados pela função:

$\mathrm{vmm}=(i-0,375) /(n+0,25)$

em que vnm é o valor não normal gerado, $i$ é o número de ordem do valor a ser estimado e $n$ é o número máximo de valores a serem estimados. Coeficientes de correlação baixos indicam que os dados observados seguem a distribuição normal.

A igualdade do parâmetro $b$ a 1 foi testada através do teste t (MADDEN et alii, 1995), usando a estimativa do parâmetro e seu desvio padrão (BANZATTO \& KRONKA, 1995). A hipótese alternativa foi a de $b>1$. Valores de $b$ significativamente diferentes de 1 ao nivel de $5 \%$ de probabilidade foram considerados indicativos de agregação e valores estatisticamente iguais a 1 foram considerados indicativos de aleatoriedade.

\subsubsection{Indice de dispersão ( I $\beta$ )}

O índice de dispersão foi calculado para todas as avaliações através da equação (GOTTWALD et alii, 1996):

$\boldsymbol{\beta}=\mathrm{v}_{\mathrm{obs}} / \mathrm{v}_{\mathrm{bin}}$

$O$ afastamento da aleatoriedade foi determinado através de teste de $\chi^{2}$ ao nível de $5 \%$ de significância, para o qual o valor a ser testado foi calculado por $\mid \beta$. $\left(N_{q}-1\right)$, em que $N_{q}$ é o número de quadrats e a expressão $N_{q}-1$ representa os graus de liberdade. Os valores de $\chi^{2}$ para os graus de liberdade usados e para o nível de significância escolhido foram calculados por.

$\chi^{2}=\frac{1}{2}[1,645+\sqrt{2 \cdot g l-1}]^{2}$ 
em que glé o número de graus de liberdade (THOMPSON, 1941).

A hipótese nula foi a de que o padrão observado era aleatório e a hipótese alternativa a de que era agregado. Valores de $1 \beta$ que não diferiram estatisticamente de 1 foram considerados como indicativo de aleatoriedade dos dados. De forma complementar, valores estatisticamente superiores a 1 foram tomados como indicativos de agregação.

\subsubsection{Determinação de áreas isópatas}

O estabelecimento das áreas isópatas para cada local e avaliação foi feito no utilitário STATISTICA 5.0, através do procedimento de uniformização dos quadrados mínimos, ponderados pela distância. Nessa determinação, foi utilizada a matriz dos valores não-transformados de proporção de plantas afetadas de cada quadrat. Para cada talhão, o número de áreas isópatas previamente escolhidas foi igual. Entretanto, os niveis de cada área isópata, para cada talhão, foram arbitrariamente escolhidos, com o objetivo de realçar possiveis diferenças.

\subsubsection{Análise de dinâmica e estrutura de focos (ADEF)}

Como premissa básica, foi adotada a seguinte definição de foco: "área de concentração localizada de plantas doentes ou lesões discretas, quer sejam fontes primárias de infecção ou coincidentes com zonas originalmente favoráveis ao estabelecimento da doença e que tendem a influenciar no padrão posterior de transmissão da doença" (BRITISH MYCOLOGICAL SOCIETY, 1953).

A ADEF foi realizada a partir dos mapas básicos de cada talhão, em cada avaliação, levando-se em conta as diretrizes estabelecidas por NELSON (1996). Considerou-se que só dividiam o mesmo foco aquelas plantas doentes imediatamente adjacentes no padrão de proximidade vertical, horizontal ou longitudinal (Figura 10). Contou-se o número de focos (NF), o número de plantas em cada foco (NPF) e o número máximo de linhas (If) e colunas (Ic) por ele ocupadas. A partir dessas 
informações, calculou-se o índice de forma de foco (IFF) e o índice de compactação de foco (ICF), por meio das seguintes funções, respectivamente:

IFF $=$ Ic $/$ If

ICF $=$ NPF / (IC)(If)

Para cada área e avaliação foram também calculados o número médio de plantas por foco (NMPF); o número de focos para cada 1000 plantas (NF1000), a percentagem de focos unitários (\%FU) e a distribuição de freqüência de NPF. O índice de forma de foco, o percentual de focos unitários e o número de focos por 1000 plantas são variáveis não consideradas por NELSON (1996). Todas as variáveis calculadas para os focos também o foram para reboleiras, definidas como aglomerados de plantas doentes separadas entre si apenas por outras plantas doentes. Nesse sentido, todos os focos são reboleiras, com exceção daqueles compostos por apenas uma planta afetada, os chamados focos unitários.

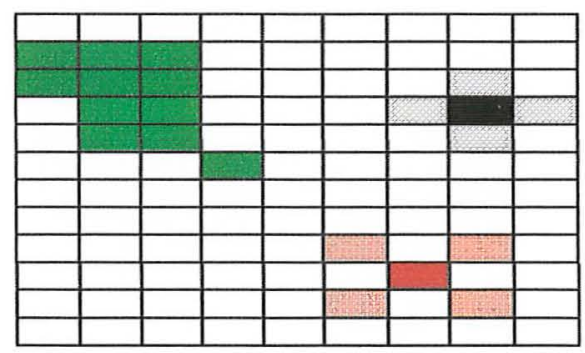

Figura 10. Exemplo de foco e de padrões de proximidade considerados pela ADEF. O foco em vermelho denota a existência de padrão de proximidade longitudinal entre unidade central e as demais. O foco em preto e cinza denota a existência dos padrões de proximidade vertical e horizontal entre a unidade central e as demais. Para o foco em verde teríamos NPF $=11$; If $=$ $4 ; \mathrm{IC}=5 ; \mathrm{IFF}=1,25$ e ICF $=0,55$. 


\subsection{Variáveis climatológicas}

Os dados climatológicos foram obtidos na Estação Experimental de Citricultura de Bebedouro, localizada entre as duas fazendas. Foram consideradas informações de precipitação, temperaturas mínimas, máximas e médias, bem como umidade relativa do ar. A direção dos ventos prevalecentes naquela região foi obtida no aeroporto de Bebedouro. 


\section{RESULTADOS}

\subsection{Avaliações}

Na maioria das avaliaçōes os sintomas foliares foram típicos, não sendo confundidos com deficièncias nutricionais (devido à similaridade de cores). Quando a quantidade de folhas com sintomas dessas deficiências era elevada os avaliadores passavam mais tempo examinando a planta. Entretanto, o mais comum nesse caso era encontrar sintomas típicos entre ramos com deficiências. A distinção entre um e outro sintoma era feita por meio da constatação de pústulas avermelhadas na face abaxial das folhas com CVC, correspondendo às áreas cloróticas da face adaxial. No periodo de outono/ínverno o comum era não encontrar sintomas foliares. Apesar disso, as detecções de novas plantas afetadas, embora em menor número, não foram interrompidas. Apenas no talhão SJ 01, para as avaliações de maio e julho de 1995, houve necessidade de dirimir dúvidas a respeito de sintomas. Não eram sintomas de deficiência nutricional, não havia frutos miúdos nem outras folhas com sintomas típicos. O teste serológico DIBA não acusou a presença de $X$. fastidiosa nos materiais coletados e, portanto, as plantas não foram contabilizadas entre as doentes. Para os talhões CQN e CQP, apenas a primeira e a última avaliações podem ser consideradas representativas, uma vez que houve poda em grande escala, com recepa de algumas plantas e arranquio de muitas. Na última avaliação, as replantas já estavam estabelecidas e os pomares recuperados do ponto de vista de biomassa suscetível. Como as informações sobre a CVC ainda são escassas, não foi possível estudar essas áreas a partir do modelo sugerido por CHAN \& JEGER (1994) para doenças de plantas com arranquio e replanta. A remoção de árvores também impossibilitou a realização de algumas análises, em relação à distribuição espacial. Em outras áreas, onde a poda foi feita, não houve arranquio de árvores e todas as 
plantas podadas ainda apresentavam sintomas não detectados pelos podadores ou continham a bactéria em seus tecidos, detectada pelo teste DIBA.

\subsection{Progresso no tempo}

As curvas de progresso da CVC para todas as áreas apresentaram duas seções distintas (Figura 11), ambas sigmóides, padrão comum para doenças policíclicas (BERGAMIN FILHO \& AMORIM, 1996).

Os dados foram ajustados aos modelos generalizados dos modelos logístico, Gompertz e monomolecular descritos por HAU et alii (1993). Esses modelos são generalizações dos modelos logístico, monomolecular e de Gompertz. Os valores dos coeficientes de determinação $\left(R^{2}\right)$, a estimativa de proporção de plantas afetadas para a assíntota ( $p 1)$ e a existência de padrões no gráfico de resíduos versus valores previstos, estão apresentados na Tabela 1 e foram utilizados como critérios para a escolha do melhor modelo.

$\mathrm{Na}$ maioria dos casos, foram obtidos bons coeficientes de determinação, ou seja, correlações entre os valores observados e os valores previstos maiores que 95\%. Apesar disso, os modelos generalizados de 5 parâmetros, Gompertz e logístico, mostraram $\mathrm{R}^{2}$ similares entre si e maiores, na média, que os outros modelos. O modelo logístico não apresentou valores de $R^{2}$ menores que 0,972 , chegando, inclusive, a valores muito altos $(0,996)$. Gompertz generalizado de 5 parâmetros, por sua vez, produziu $R^{2}$ variando de 0,956 a 0,997 . O uso dos modelos resultou, apenas para alguns ajustes, na ocorrência de padrões dos resíduos, em função dos valores previstos, sendo mais freqüente para os modelos de quatro parâmetros. Dentre todos os modelos utilizados, apenas o logístico com 5 parâmetros não gerou padrões nos gráficos de resíduos. A utilização desse critério, na escolha do melhor modelo, é considerada muito importante e, idealmente, os resíduos devem ser 

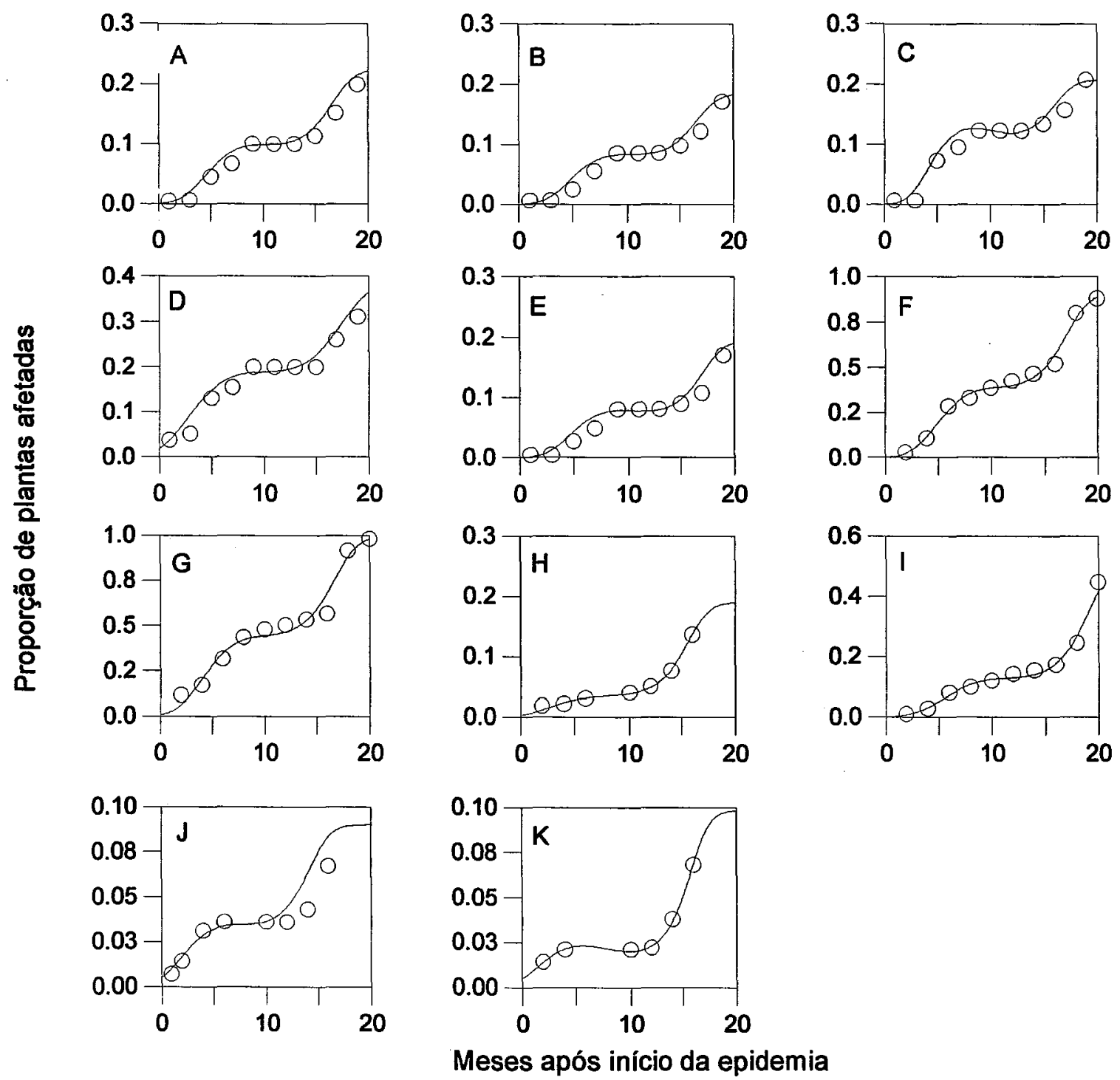

Figura 11 - Curvas de progresso da CVC estimadas (linha contínua) e dados originais (círculos) para os talhões SJ 01 (A), SJ 01-2 (B), SJ 01-3 (C), SJ 01-4 (D), SJ 01-5 (E), SJ 67 (F), SJ 71 (G), SJ $73(H)$, SJ 75 (I), SJ 83 (J) e CQH (K). 

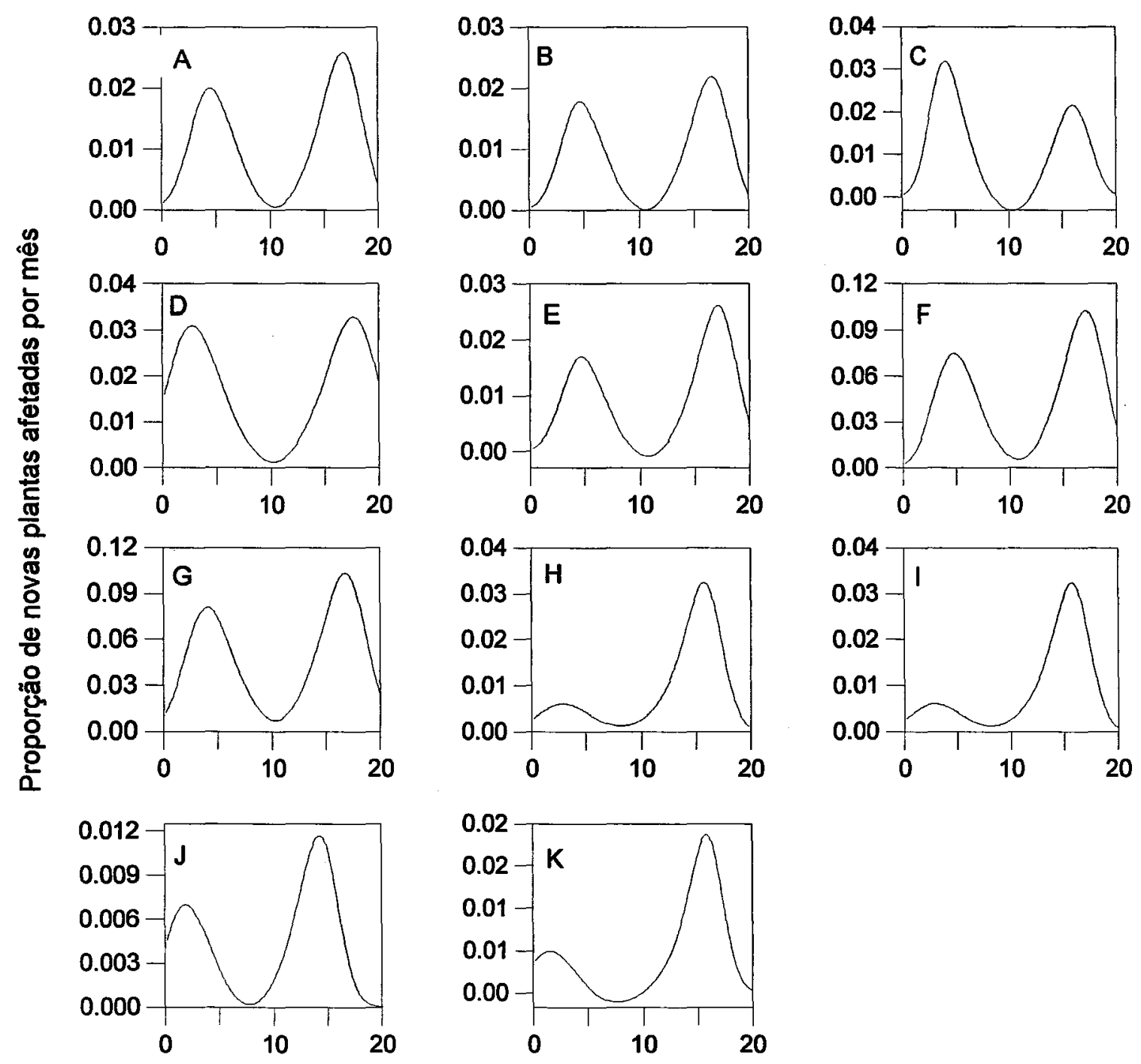

Meses após início da epidemia

Figura 12 - Derivadas das curvas de progresso da CVC estimadas para os talhões SJ 01 (A), SJ 01-2 (B), SJ 01-3 (C), SJ 01-4 (D), SJ 01-5 (E), SJ 67 (F), SJ 71 (G), SJ 73 (H), SJ 75 (I), SJ $83(J)$ e CQH (K). 

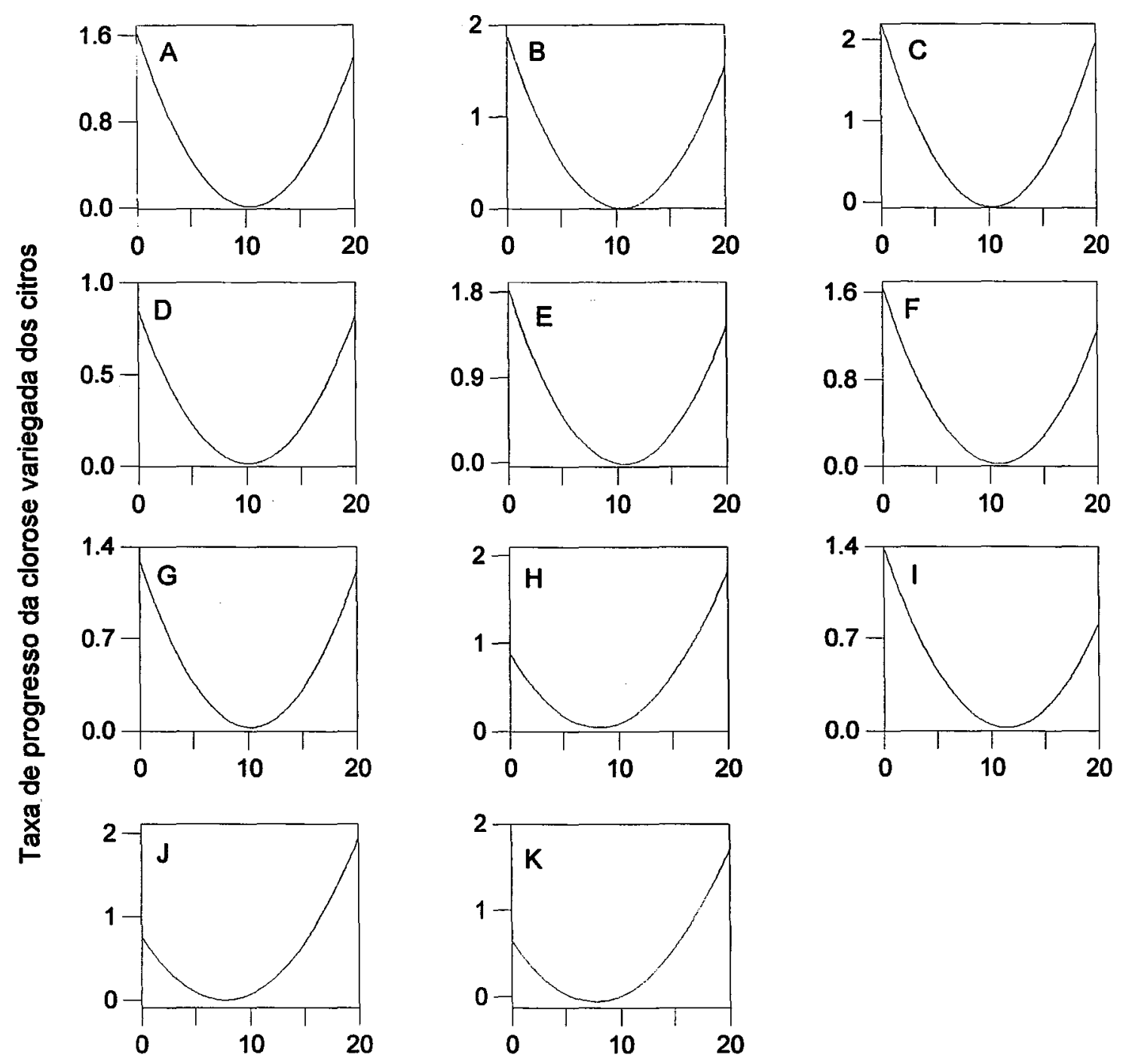

Meses após início da epidemia

Figura 13 - Variação das taxas de progresso da CVC para os talhões SJ 01 (A), SJ 01-2 (B), SJ 01-3 (C), SJ 01-4 (D), SJ 01-5 (E), SJ 67 (F), SJ 71 (G), SJ 73 (H), SJ 75 (I), SJ 83 (J) e CQH (K). 


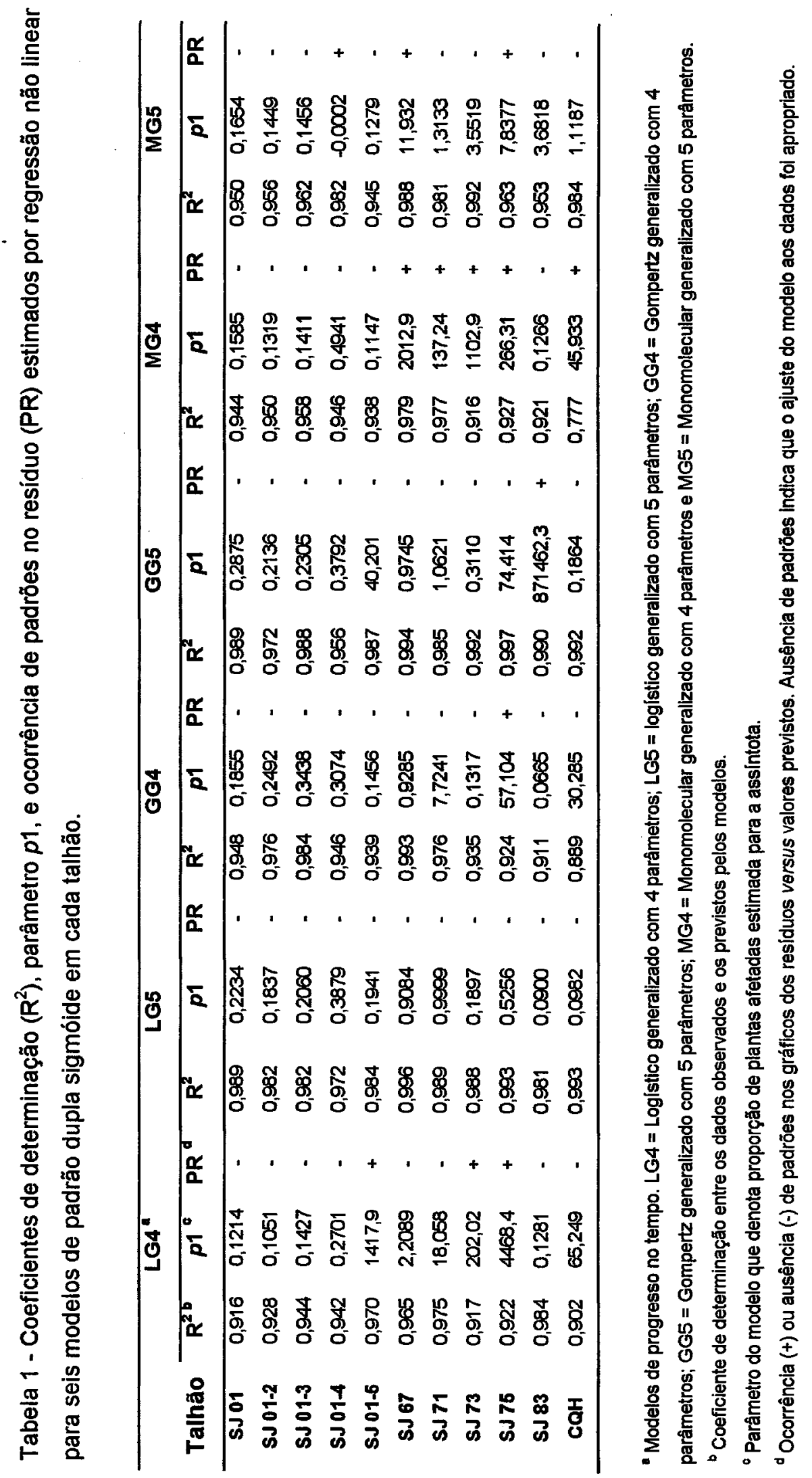


muito próximos de zero e estar distribuídos de forma aleatória, em função da variável independente (CAMPBELL \& MADDEN, 1990).

Os modelos de cinco parâmetros foram menos pródigos em estimativas não-acuradas do parâmetro $p 1$, e não houve relação detectável entre incidência da doença e presença de estimativas não-acuradas. Os dados utilizados no ajuste dos modelos estavam transformados em proporção de plantas afetadas e, assim, qualquer boa estimativa daquele parâmetro deveria concentrar-se no domínio compreendido pelo último valor observado no campo e o valor máximo de proporção (1). Como pode ser visto na Tabela 1, apenas o modelo logístico de 5 parâmetros não apresentou valores de p1 fora do esperado. Essas estimativas sem sentido foram geralmente maiores que o valor 1 de proporção e, em apenas um caso (monomolecular de 5 parâmetros para SJ 01-4), foi menor que o último valor observado. Baseado nos resultados obtidos para esses três critérios, o modelo logístico generalizado de 5 parâmetros foi escolhido como o mais representativo das curvas de progresso observadas.

Como a relação entre dados observados e dados previstos pelo modelo logístico generalizado de 5 parâmetros pode ser considerada excelente para todas as áreas, a partir daqui todas as relaçōes e comentários serão feitos com base nesses dados. Já que podem ser calculados com relativa segurança e em mais pontos que os dados originais, as relaçōes inferidas podem ser melhor visualizadas com seu uso. Quando necessário, far-se-á referência às informaçōes obtidas no campo. Na Figura 11 são apresentadas as curvas previstas pelo modelo e os dados originais. Na Figura 12 são mostradas as derivadas das curvas estimadas.

Os valores dos parâmetros das equações de cada área estão apresentados na Tabela 2 . Os parâmetros de taxa ( $p 3, p 4$ e $p 5)$ foram usados para os demais cálculos, de acordo com HAU et alii (1993). As taxas médias e mínimas de progresso da doença, bem como o tempo para a ocorrência dos valores mínimos e época do ano em que ocorreram estão apresentadas na Tabela 3. Os valores estimados de inóculo inicial $\left(e^{02}\right)$ estão apresentados na Tabela 4. 
Tabela 2 - Valores estimados dos parâmetros da equação logistica generalizada de 5 parâmetros para cada talhão.

\begin{tabular}{cccccc}
\hline Talhão & $\boldsymbol{p 1}$ & $\boldsymbol{p 2}$ & $\boldsymbol{p 3}$ & $\boldsymbol{p 4}$ & $\boldsymbol{p 5}$ \\
\hline SJ 01 & 0,223404 & $-5,99965$ & 1,647071 & $-0,15764$ & 0,005056 \\
SJ 01-2 & 0,183702 & $-6,84249$ & 1,896987 & $-0,18036$ & 0,005720 \\
SJ 01-3 & 0,206010 & $-6,85258$ & 2,232432 & $-0,22309$ & 0,007227 \\
SJ 01-4 & 0,387865 & $-3,02567$ & 0,855910 & $-0,08343$ & 0,002753 \\
SJ 01-5 & 0,194076 & $-6,79886$ & 1,848585 & $-0,17599$ & 0,005528 \\
SJ 67 & 0,908384 & $-6,41434$ & 1,664674 & $-0,15286$ & 0,004749 \\
SJ 71 & 0,999999 & $-4,85385$ & 1,306881 & $-0,12548$ & 0,004108 \\
SJ 73 & 0,189739 & $-4,13722$ & 0,883889 & $-0,10270$ & 0,004199 \\
SJ 75 & 0,525632 & $-6,63747$ & 1,396304 & $-0,120339$ & 0,003522 \\
SJ 83 & 0,09 & $-2,87837$ & 0,920908 & $-0,11838$ & 0,005120 \\
CQH & 0,098244 & $-2,95832$ & 0,780317 & $-0,10886$ & 0,004683 \\
\hline
\end{tabular}

Tabela 3 - Valores médios e mínimos estimados para taxa de infecção, tempo para ocorrência dos valores mínimos, em meses e época do ano em que ocorreram.

\begin{tabular}{ccccc}
\hline Talhão & $\mathbf{r}$ médio & $\mathbf{r}$ mínimo & $\begin{array}{c}\text { Tempo para r mínimo } \\
\text { (meses) }\end{array}$ & Época de r mínimo \\
\hline SJ 01 & 0,448 & $-0,000132$ & 10,39 & Inverno \\
SJ 01-2 & 0,504 & $-0,000023$ & 10,51 & Inverno \\
SJ 01-3 & 0,558 & 0,001368 & 10,29 & Inverno \\
SJ 01-4 & 0,246 & $-0,000108$ & 10,10 & Inverno \\
SJ 01-5 & 0,472 & 0,000316 & 10,61 & Inverno \\
SJ 67 & 0,410 & $-0,000350$ & 10,73 & Outono \\
SJ 71 & 0,370 & $-0,000361$ & 10,18 & Outono \\
SJ 73 & 0,396 & $-0,000587$ & 8,15 & Inverno \\
SJ 75 & 0,313 & $-0,000272$ & 11,39 & Inverno \\
SJ 83 & 0,267 & $-0,000131$ & 7,71 & Inverno \\
CQH & 0,174 & 0,000888 & 7,75 & Inverno
\end{tabular}


Tabela 4 - Valor estimado para o inóculo inicial $\left(e^{p 2}\right)$, em proporção de plantas afetadas, para cada talhão.

\begin{tabular}{cc}
\hline Talhão & Inóculo inicial \\
\hline SJ 01 & 0,0025 \\
SJ 01-2 & 0,0011 \\
SJ 01-3 & 0,0011 \\
SJ 01-4 & 0,0485 \\
SJ 01-5 & 0,0011 \\
SJ 67 & 0,0016 \\
SJ 71 & 0,0078 \\
SJ 73 & 0,0159 \\
SJ 75 & 0,0013 \\
SJ 83 & 0,0562 \\
CQH & 0,0519 \\
\hline
\end{tabular}

Como paradigma desse tipo de modelo, as taxas são altamente variáveis (Figura 13), com uma curva caracteristicamente parabólica e valores de mínimo iguais ou menores que zero (HAU et alii, 1993). De acordo com HAU et alii (1993), a curva da variação de $r$ em função do tempo pode ser descrita por uma função quadrática, cujo discriminante, o valor de mínimo, é dado pela equação $D=(p 4)^{2}-3(p 3)(p 5)$. Segundo os mesmos autores, valores menores que zero indicam ausência de ponto de inflexão e inclinação da curva de progresso sempre positiva. Todos os discriminantes calculados ( $r$ mínimos) são valores muito próximos de zero e foram considerados como tal. O tempo de ocorrência dos valores mínimos de $r$, segundo previsão do modelo, variou entre cerca de oito meses e pouco menos de onze meses, a partir do início das epidemias. A época de ocorrência do r mínimo (Tabela 3) foi sempre a mesma para todas as áreas, ou seja, outono ou inverno. 
As taxas médias variaram de 0,174 a 0,558 ao mês. Para os dois talhões que, na última avaliação, não haviam alcançado 10\% de incidência (SJ 83 e CQH) foram observadas $r$ inferiores a 0,300 ao mês. $O$ talhão SJ $01-4$, que alcançou cerca de $35 \%$ de plantas afetadas, também apresentou $r$ dessa ordem. Nas outras áreas, os valores de $r$ foram considerados altos, ficando entre 0,301 e o valor máximo observado $(0,558)$.

As derivadas dy/dt (Figura 12) apresentaram formato característico, com dois picos de máxima (BERGAMIN FILHO \& AMORIM, 1996). Com exceção da sub-área SJ 01-3, nas demais o segundo pico foi maior que o primeiro, não importando se os levantamentos foram iniciados com uma incidência alta ou baixa de plantas doentes. Em todos os casos, esses picos coincidiram com a primavera e o verão de 1994/1995 e de 1995/1996 (Figura 14 e Tabela 5). As médias das taxas de progresso da CVC na primavera e verão não foram diferentes entre si pelo teste Tukey a $5 \%$ de probabilidade, mas diferiram das médias do outono e do inverno, que foram estatisticamente iguais. Para facilitar os cálculos, considerou-se cada estação do ano como o período compreendido entre os solstícios e os equinócios, muito embora as relaçōes observadas devam estar mais diretamente ligadas às condições ambientais que a períodos de tempo previamente definidos. Nessa linha, para alguns casos, a primavera de 1995/1996 esteve relacionada a valores baixos de r, se comparada à primavera anterior.

Embora seja possivel notar alguma semelhança entre as curvas de derivada previstas e as curvas de precipitação pluviométrica (Figura 15), de temperatura média (Figura 16) e umidade relativa do ar (Figura 17), não foi possivel correlacionar de maneira clara os fatores climáticos com as derivadas (Tabela 6). Apesar da maioria das relações ser significativa ao nivel de $5 \%$, os valores de $R^{2}$ foram, via de regra, baixos. 
Tabela 5 - Taxas de infecção estimadas para cada estação do ano, para cada talhão, a partir do modelo logístico generalizado de cinco parâmetros.

\begin{tabular}{ccccccc}
\hline Talhão & Primavera 1 $^{\text {a }}$ & Verão 1 & Outono & Inverno & Primavera 2 & Verão 2 \\
\hline SJ 01 & 1,219 & 0,547 & 0,147 & 0,020 & 0,166 & 0,586 \\
SJ 01-2 & 1,407 & 0,634 & 0,170 & 0,014 & 0,168 & 0,630 \\
SJ 01-3 & 1,628 & 0,679 & 0,122 & $-0,046$ & 0,177 & 0,789 \\
SJ 01-4 & 0,630 & 0,278 & 0,075 & 0,021 & 0,115 & 0,358 \\
SJ 01-5 & 1,370 & 0,613 & 0,154 & $-0,006$ & 0,132 & 0,568 \\
SJ 67 & 0,779 & 0,290 & 0,057 & 0,079 & 0,359 & 0,896 \\
SJ 71 & 0,589 & $\mathbf{0 , 2 0 6}$ & 0,044 & 0,105 & 0,387 & 0,891 \\
SJ 73 & 0,725 & 0,458 & 0,145 & 0,058 & 0,197 & 0,563 \\
SJ 75 & 0,691 & 0,286 & 0,071 & 0,047 & 0,212 & 0,568 \\
SJ 83 & $\#$ & 0,738 & 0,292 & 0,042 & 0,069 & 0,373 \\
CQH & $\#$ & 0,613 & 0,201 & $-0,031$ & $-0,009$ & 0,265 \\
\hline
\end{tabular}

a Primavera 1 = setembro a novembro de1994. Verão 1 = dezembro a fevereiro de 1995. Outono = março a maio de 1995. Inverno = junho a agosto. Primavera 2 = setembro a novembro de 1995 . Verăo 2 = dezembro a fevereiro de 1996. \# indica impossibilidade de cálculo da taxa por ausência de plantas sintomáticas.

Tabela 6 - Coeficientes de correlação $\left(R^{2}\right)$ entre as derivadas das curvas de progresso estimadas para cada talhão e variáveis climáticas, e a probabilidade de erro associada a cada correlação $(P)$.

\begin{tabular}{|c|c|c|c|c|c|c|}
\hline \multirow[b]{2}{*}{ Talhões } & \multicolumn{2}{|c|}{$\begin{array}{c}\text { Precipitação } \\
\text { Pluviométrica } \\
\text { Mensal }\end{array}$} & \multicolumn{2}{|c|}{$\begin{array}{l}\text { Temperatura } \\
\text { Média Mensal }\end{array}$} & \multicolumn{2}{|c|}{$\begin{array}{c}\text { Umidade } \\
\text { Relativa do Ar } \\
\text { Média Mensal }\end{array}$} \\
\hline & $\mathbf{R}^{2}$ & $\mathbf{P}$ & $\mathbf{R}^{2}$ & $\mathbf{P}$ & $\mathbf{R}^{2}$ & $\mathbf{P}$ \\
\hline SJ 01 & 0,166 & 0,074 & 0,243 & 0,027 & 0,102 & 0,170 \\
\hline & & & & & & \\
\hline & 0,0 & 0,188 & 0,205 & 0,045 & 0,004 & 0,793 \\
\hline & & & 0,2 & & & 0,978 \\
\hline & 0,230 & 0,032 & 0,276 & 0,017 & 0,212 & 0,041 \\
\hline SJ 67 & 0,274 & 0,018 & 295 & 0,013 & 0,260 & 0,022 \\
\hline & & & & & & 0,376 \\
\hline & 019 & & 0,0 & & & 0,878 \\
\hline SJ 75 & 0,1 & 0,0 & 0,249 & 0,025 & 0,518 & 0,000 \\
\hline & & & & & $-0,432$ & 0,002 \\
\hline $\mathrm{CQH}$ & $-0,041$ & 0,392 & 0,000 & 0,946 & $-0,021$ & 0,545 \\
\hline
\end{tabular}




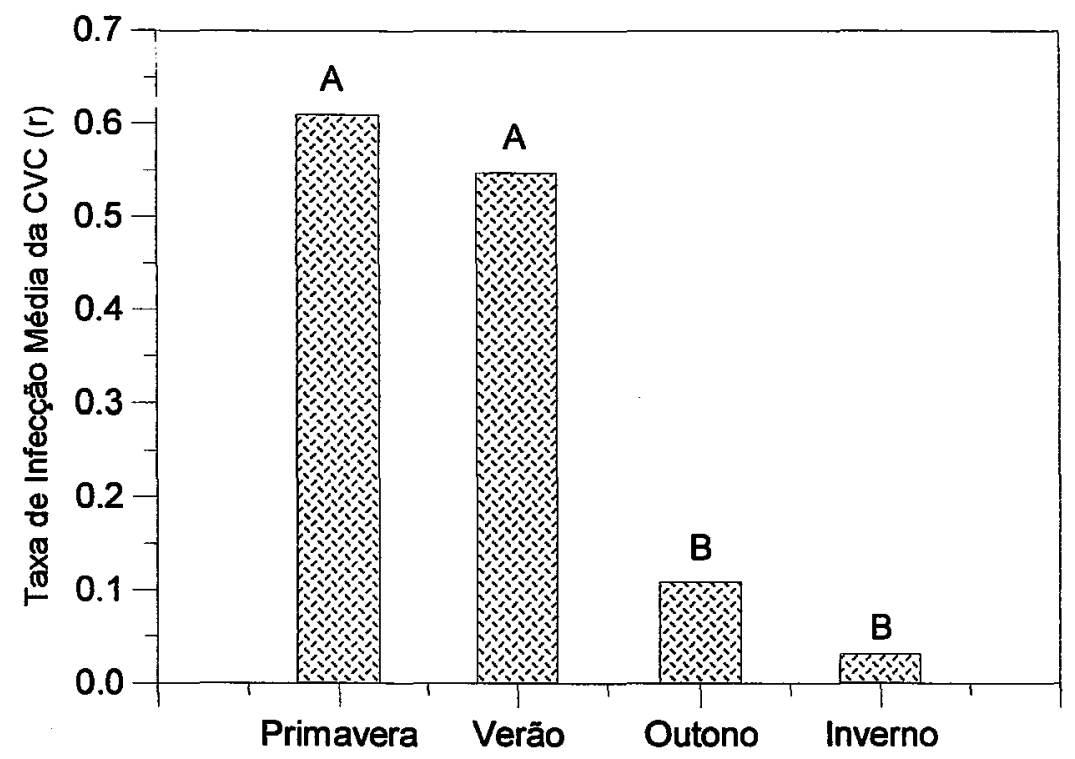

Figura 14 - Médias da taxa de infecção da CVC (r) para as quatro estaçōes do ano, em 11 talhões. As letras acima das colunas identificam o resultado do teste Tukey a $5 \%$ de probabilidade; letras iguais significam que as médias não diferiram estatisticamente. 

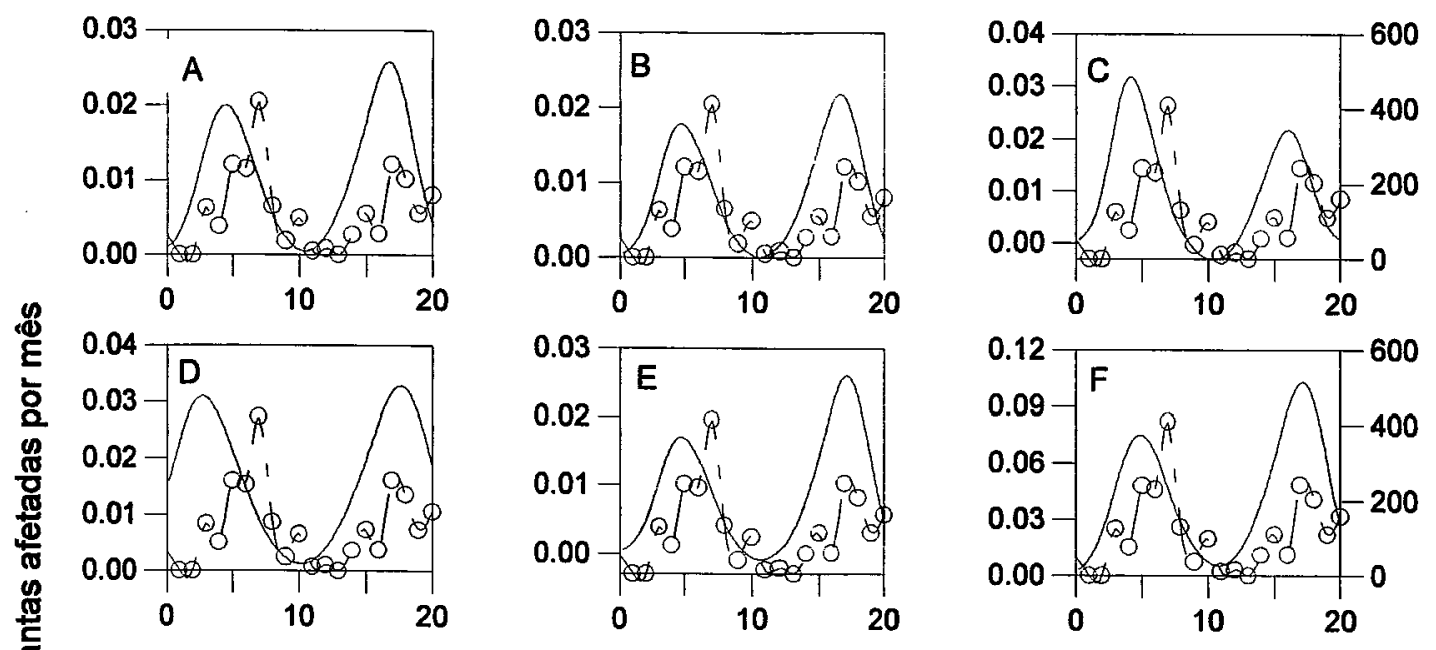

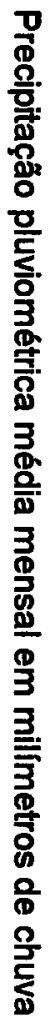
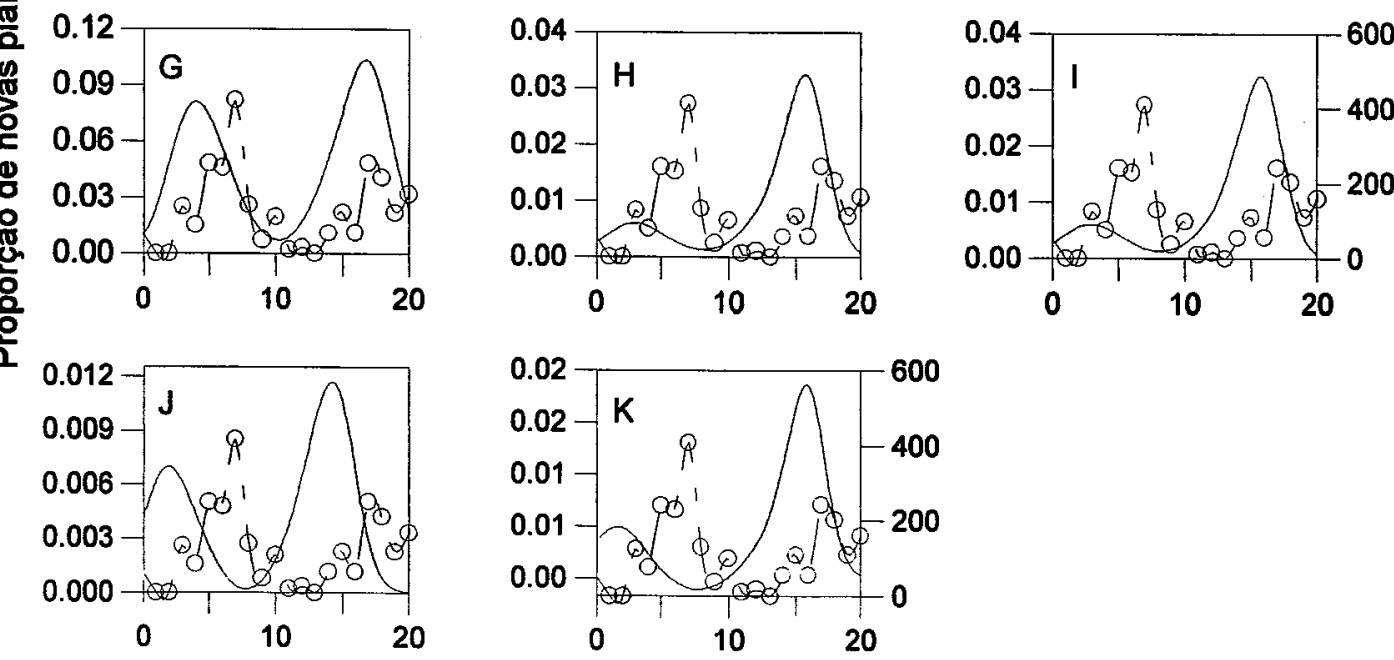

Meses após início da epidemia

Figura 15 - Relação entre precipitação pluviométrica mensal (círculos) e derivadas das curvas de progresso da CVC (linha contínua) para os talhões SJ 01 (A), SJ 01-2.(B), SJ 01-3 (C), SJ 01-4 (D), SJ 01-5 (E), SJ 67 (F), SJ $71(G)$, SJ $73(H)$, SJ 75 (I), SJ 83 (J) e CQH (K). 

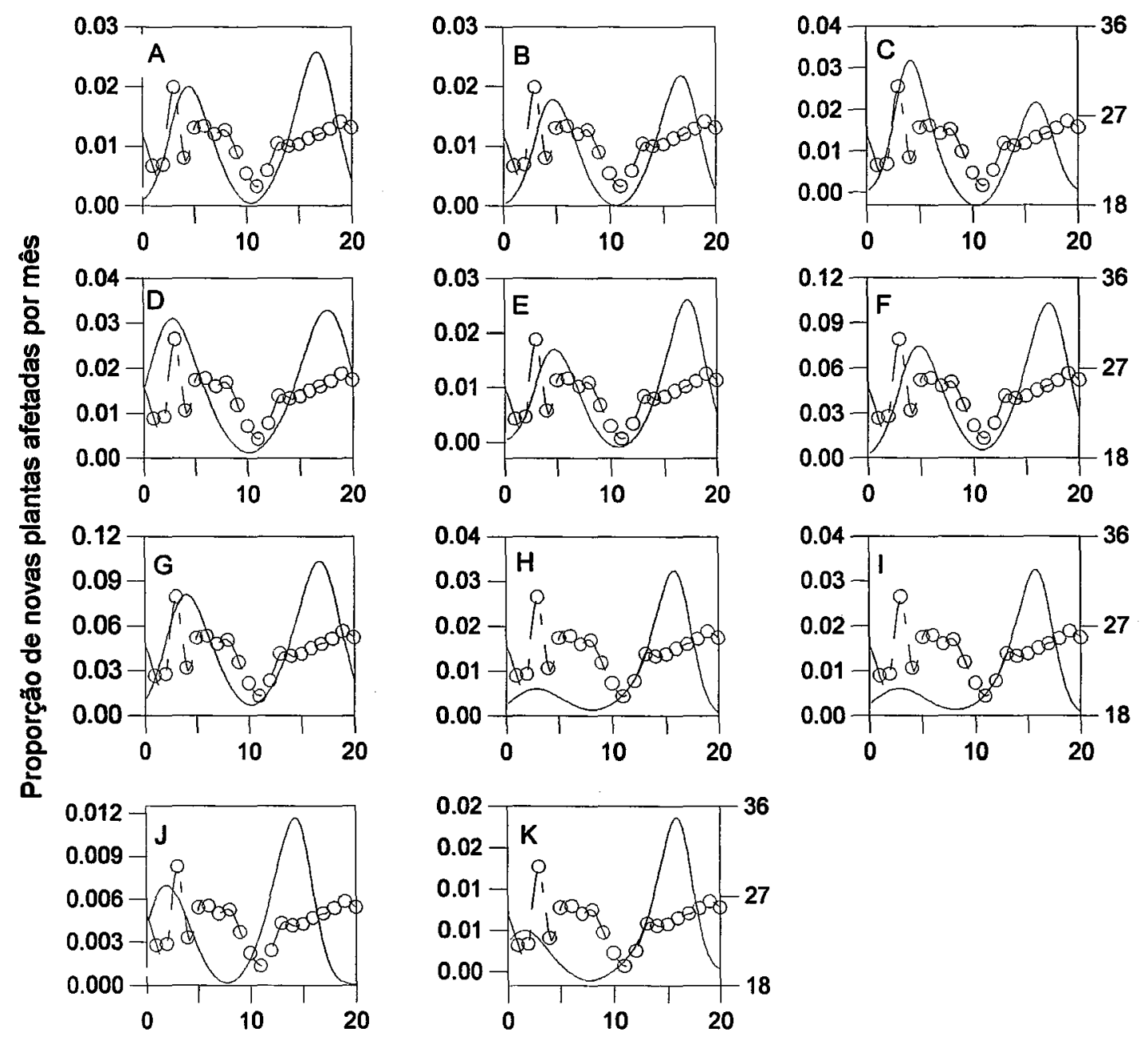

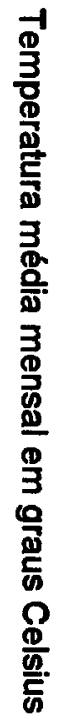

Meses após início da epidemia

Figura 16 - Relação entre temperatura média mensal (círculos) e derivadas das curvas de progresso da CVC (linha contínua) para os talhões SJ 01 (A), SJ 01-2 (B), SJ 01-3 (C), SJ 01-4 (D), SJ 01-5 (E), SJ 67 (F), SJ 71 (G), SJ $73(H)$, SJ 75 (I), SJ 83 (J) e CQH (K). 

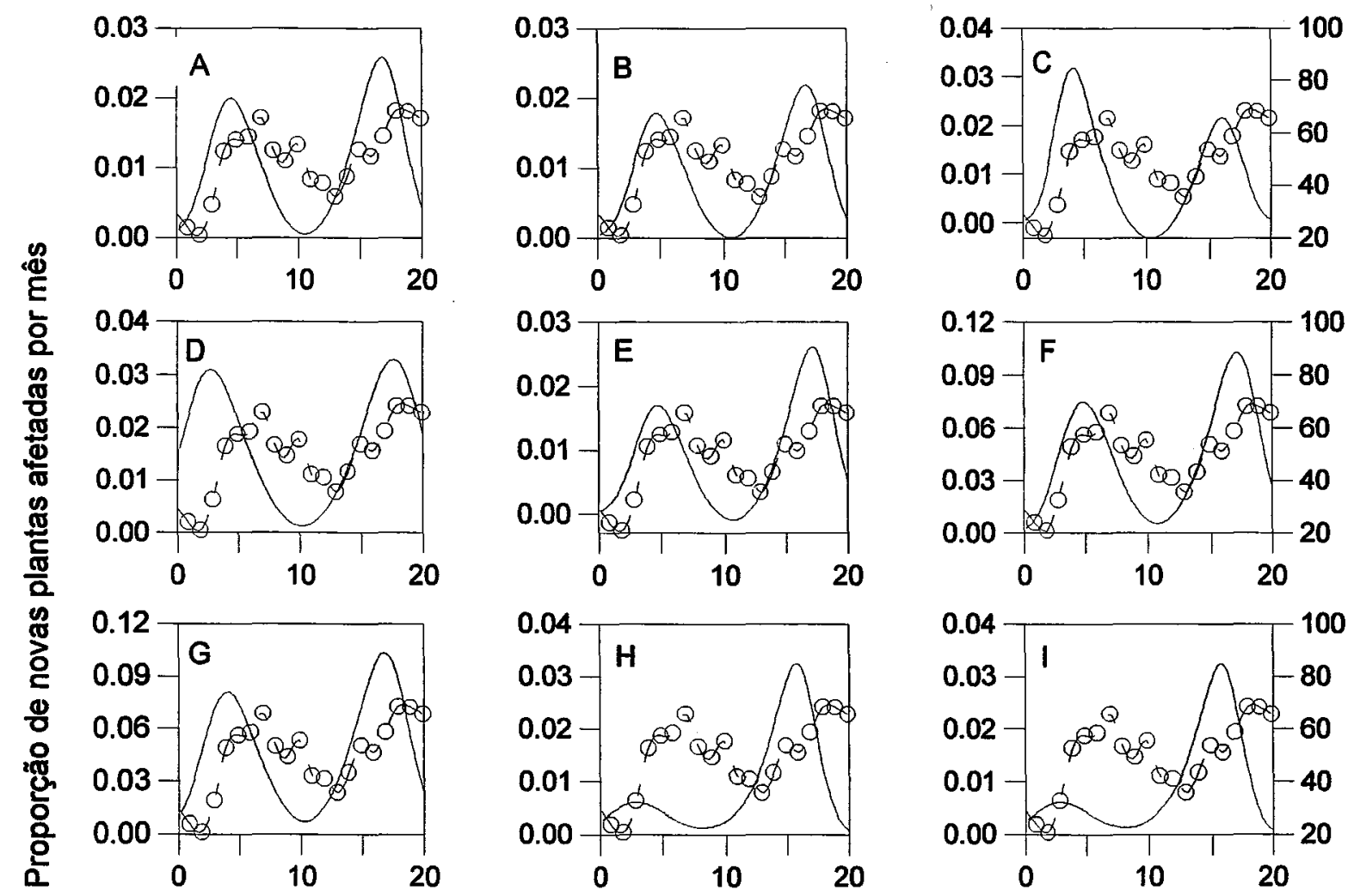

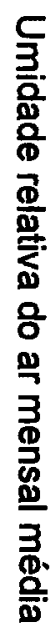
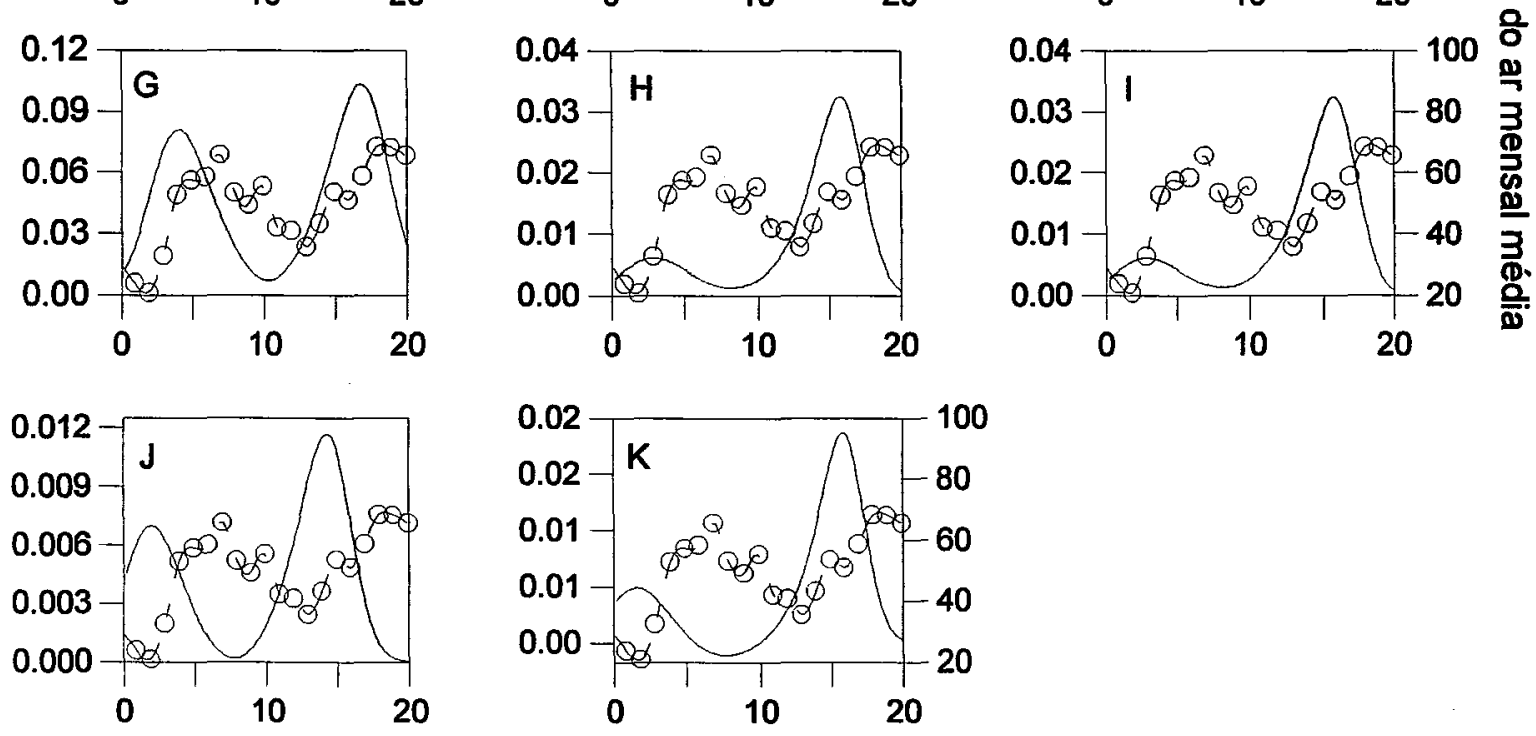

Meses após início da epidemia

Figura 17 - Relação entre umidade relativa do ar mensal média (círculos) e derivadas das curvas de progresso da CVC (linha contínua) para os talhões SJ 01 (A), SJ 01-2 (B), SJ 01-3 (C), SJ 01-4 (D), SJ 01-5 (E), SJ 67 (F), SJ $71(G)$, SJ $73(H)$, SJ 75 (I), SJ 83 (J) e CQH (K). 
Na Figura 18 está apresentada a relação entre o valor estimado para o inóculo inicial e r. Pode-se observar que r está ligado de forma inversa ao inóculo inicial, ou seja, na medida em que o inóculo inicial aumenta, a taxa de progresso diminui exponencialmente. Para proceder à regressão, os dados do inóculo inicial foram mantidos como $p 2$, parâmetro da equação logística generalizada, que nada mais é que o In yinicial. A correlação foi significativa ao nível de $5 \%$ de probabilidade, com um coeficiente de determinação $\left(R^{2}\right)$ de 0,679 .

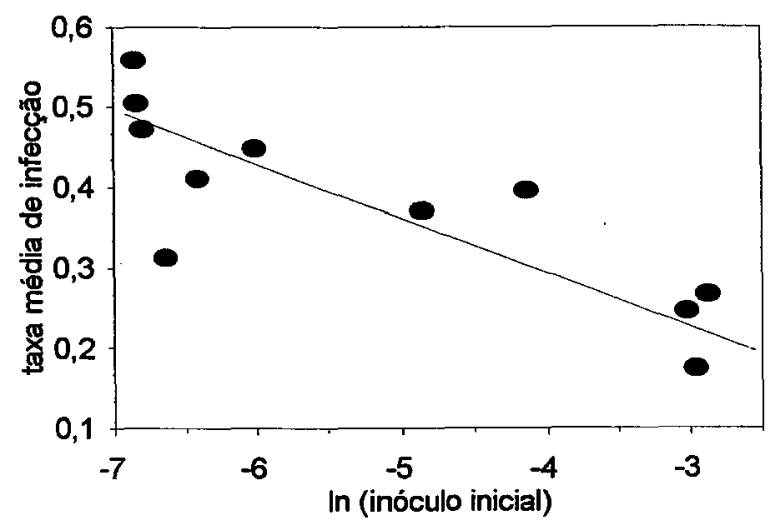

Figura 18 - Relação inversa entre o logaritmo neperiano do inóculo inicial (p2) e a taxa média de infecção $\left(r_{m}\right)$ das onze áreas avaliadas. 


\subsection{Distribuição espacial}

Todas as análises realizadas tiveram como base os mapas das Figuras 19 a 28. Nesses mapas, as áreas estão delimitadas por linhas contínuas, dentro das quais as plantas doentes foram representadas por quadrados pretos.

\subsubsection{Análise de sequências ordinárias (ASO)}

Para todas os talhões foi calculada a proporção de linhas com agregação significativa de plantas doentes. Para as sub-áreas SJ 01-2, SJ 01-3, SJ 01-4 e SJ 01-5 foi calculado o nível de agregação geral. As duas aplicações da técnica foram sugeridas por CAMPBELL \& MADDEN (1990). A escolha depende do interesse do pesquisador ou do número de plantas por linha. Nos casos em que esse número é bem menor que vinte, o segundo tipo de aplicação é o mais recomendado.

A variação na proporção de linhas agregadas (PLA), ou no índice de agregação estão apresentados na Figura 29 e na Tabela 7, respectivamente. De uma maneira geral, não foi observada relação entre a agregação de plantas doentes e a incidência. Por outro lado, o percentual de linhas agregadas tendeu a variar menos entre o outono e o inverno (Figura 29). Os talhōes com as maiores variações em PLA foram o SJ 71 , SJ 67 e o SJ 75 . No SJ 71 houve variação de 0 a mais de $30 \%$ de linhas com agregação, com o pico ocorrendo em março de 1995 e o valor mais baixo em janeiro de 1996. No SJ 67 , houve variação de 0 a mais de $50 \%$, o valor mais baixo ocorrendo em novembro de 1994 e o mais alto, em maio de 1995. Para o SJ 75 a variação foi um pouco menor, com um percentual mínimo de $0 \%$ em setembro de 1994 e um pico de pouco mais de $20 \%$ de linhas agregadas em janeiro de 1996 . O SJ 01, ao contrário, foi o talhão com a menor alternância de PLA. Na maioria das avaliações esse valor foi 0\%, com exceção da avaliação de janeiro de 1995, embora nessa data, o PLA não tenha chegado a $5 \%$. Os talhões CQH e SJ 73 , apesar de terem sofrido pouca variação no PLA, apresentaram valores mais altos que os do SJ 01. O pico de linhas agregadas do $\mathrm{CQH}$ ocorreu na última avaliação, embora não tenha chegado a $35 \%$ de linhas agregadas. No SJ 73 , o pico foi ainda menos intenso, com $15 \%$. O talhão SJ 83 , não representado na Figura 29 , não apresentou linhas com 
agregação significativa em nenhuma das avaliações, ou seja, seu PLA foi sempre igual a zero. O PLA médio, considerando todos os talhões e todas as épocas, foi de 16,1\%. Observou-se que o PLA máximo se deu no talhão SJ 67 . Na avaliação de 05/95, 55,6\% das linhas apresentavam plantas doentes significativamente aglomeradas, ao nível de $5 \%$ de probabilidade.

Tabela 7 - Índice de agregação geral de seis talhões em 10 épocas, calculado pela análise de sequências ordinárias.

\begin{tabular}{lcccccccccc}
\hline Talhões & $\mathbf{0 9 / 9 4}$ & $\mathbf{1 1 / 9 4}$ & $\mathbf{0 1 / 9 5}$ & $\mathbf{0 3 / 9 5}$ & $\mathbf{0 5 / 9 5}$ & $\mathbf{0 7 / 9 5}$ & $\mathbf{0 9 / 9 5}$ & $\mathbf{1 1 / 9 5}$ & $\mathbf{0 1 / 9 6}$ & $\mathbf{0 3 / 9 6}$ \\
\hline SJ 01 - 2 & 4,68 & 4,68 & $\mathbf{1 , 2 2}$ & $\mathbf{1 , 1 5}$ & $-0,57$ & $-0,57$ & $-0,57$ & $-1,08$ & $-2,09$ & $-1,39$ \\
SJ 01 - 3 & $\mathbf{4 , 8 8}$ & 4,88 & 0,21 & $-0,57$ & $-1,80$ & $-1,80$ & $-1,80$ & $-1,33$ & $-2,23$ & $-2,56$ \\
SJ 01 - 4 & 1,09 & 1,20 & 0,19 & $-2,14^{\mathrm{b}}$ & $-2,14$ & $-2,14$ & $-2,14$ & $-2,14$ & $-3,30$ & $-2,19$ \\
SJ 01 - 5 & 5,41 & 5,41 & 1,10 & $-0,31$ & $-0,28$ & $-0,28$ & $-0,28$ & $-1,63$ & $-0,83$ & 1,77 \\
CQN & $\#^{\text {a }}$ & $\#$ & 0,16 & $\#$ & $\#$ & $\#$ & $\#$ & $\#$ & $\#$ & 0,63 \\
CQP & $\#$ & $\#$ & $-0,66$ & $\#$ & $\#$ & $\#$ & $\#$ & $\#$ & $\#$ & $-0,30$ \\
\hline
\end{tabular}

${ }^{a}$ \# indica análise não-realizada.

${ }^{\mathrm{b}}$ Os índices em vermelho indicam significância ao nível de $5 \%$ de probabilidade.

Para as áreas onde se optou pelo cálculo de um valor geral (Tabela 7), apenas no SJ 01-3 e SJ 01-4 observou-se uma tendência ao agrupamento. Nos demais, apenas no SJ 01-2 houve uma avaliação com índice menor que $-1,64$, mas que se mostrou ocasional, não denotando uma tendência. Para o CQN e o CQP, devido aos arranquios de árvores doentes, só foi possível a realização da análise de seqüências ordinárias (ASO) em duas avaliações. Nota-se que a ASO indica aleatoriedade para ambos os casos. No CQN, além disso, houve uma leve tendência à regularidade, já que os valores obtidos são positivos. 

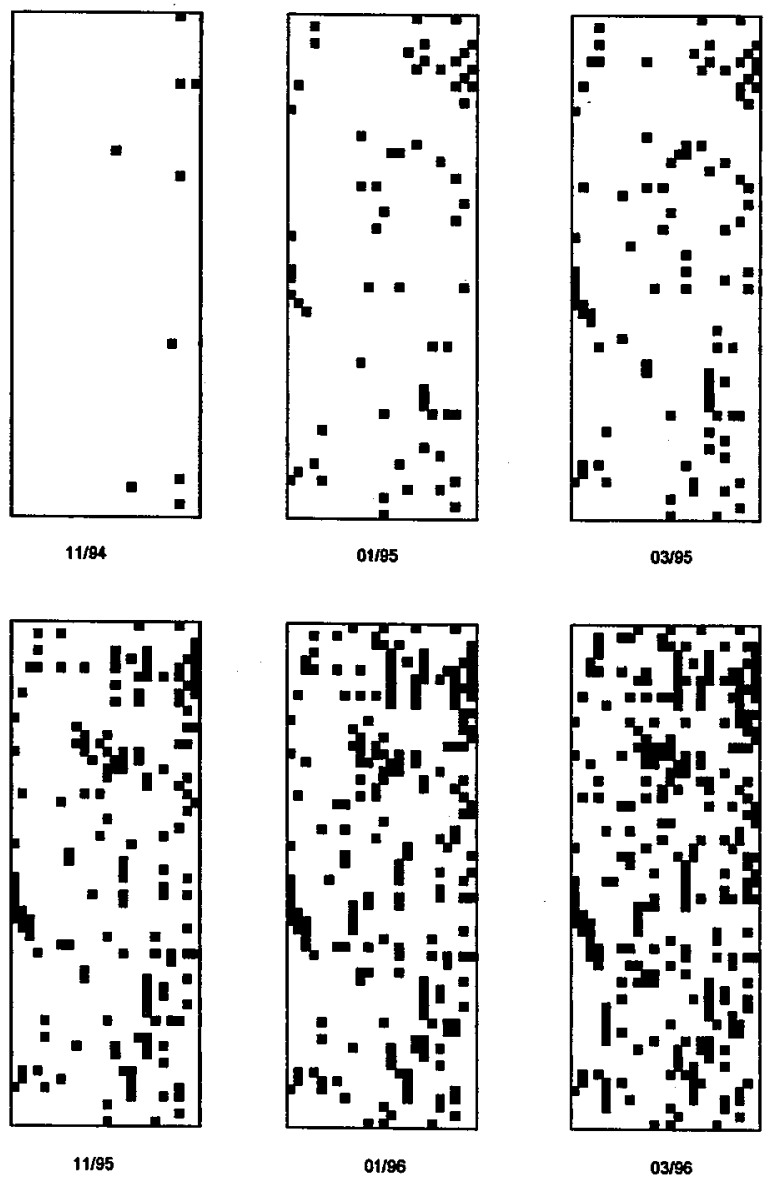

Figura 19 - Mapas de seis avaliações representativas (11/94, 01/95, 03/95, 11/95, 01/96 e 03/96) do talhão SJ 01. Cada quadrado preto representa uma planta sintomática. 


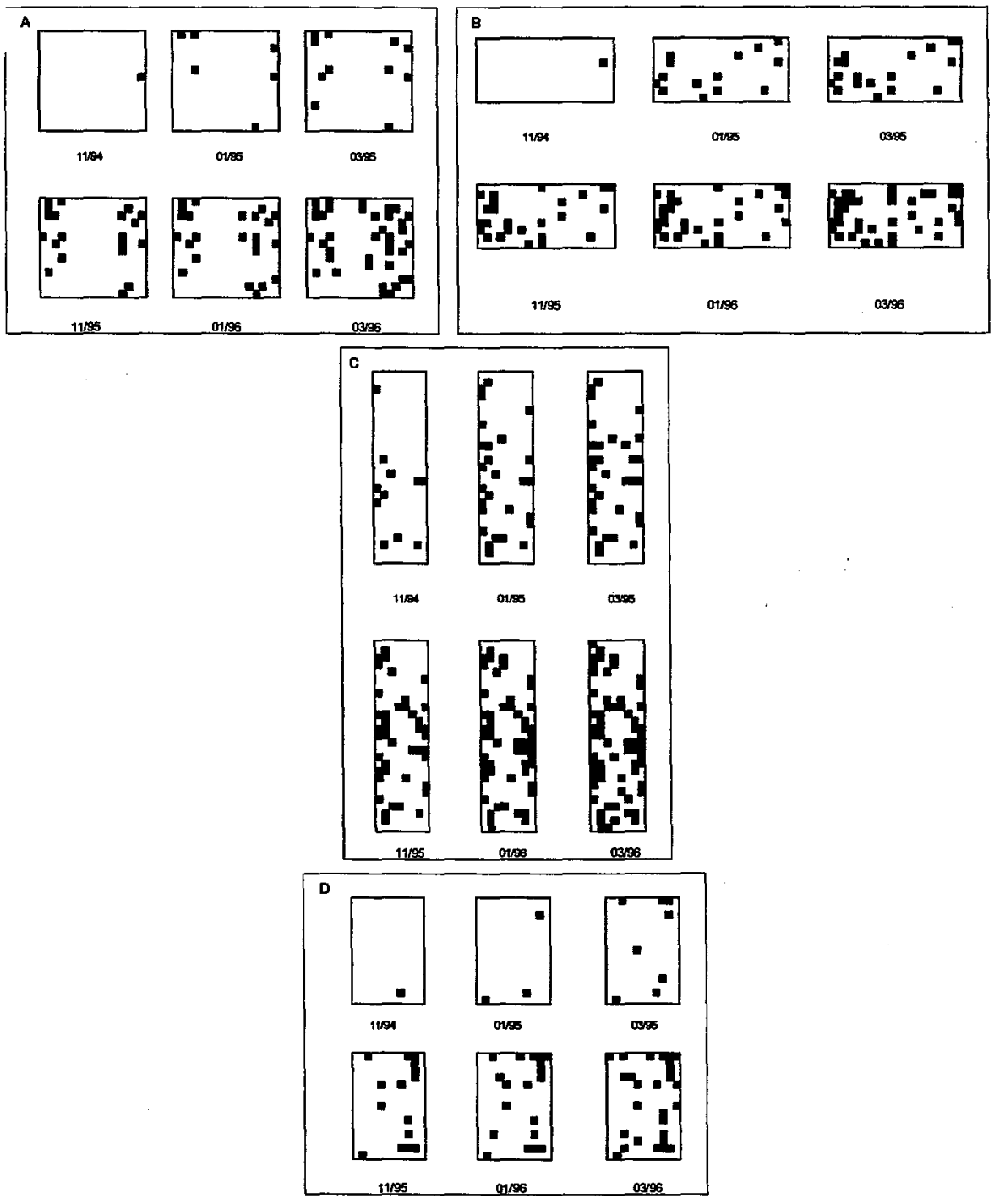

Figura 20 - Mapas de seis avaliações representativas (11/94, 01/95, 03/95, 11/95, 01/96 e 03/96) dos talhões SJ 01-2 (A), SJ 01-3 (B), SJ 01-4 (C) e SJ 01-5 (D). Cada quadrado preto representa uma planta sintomática. 

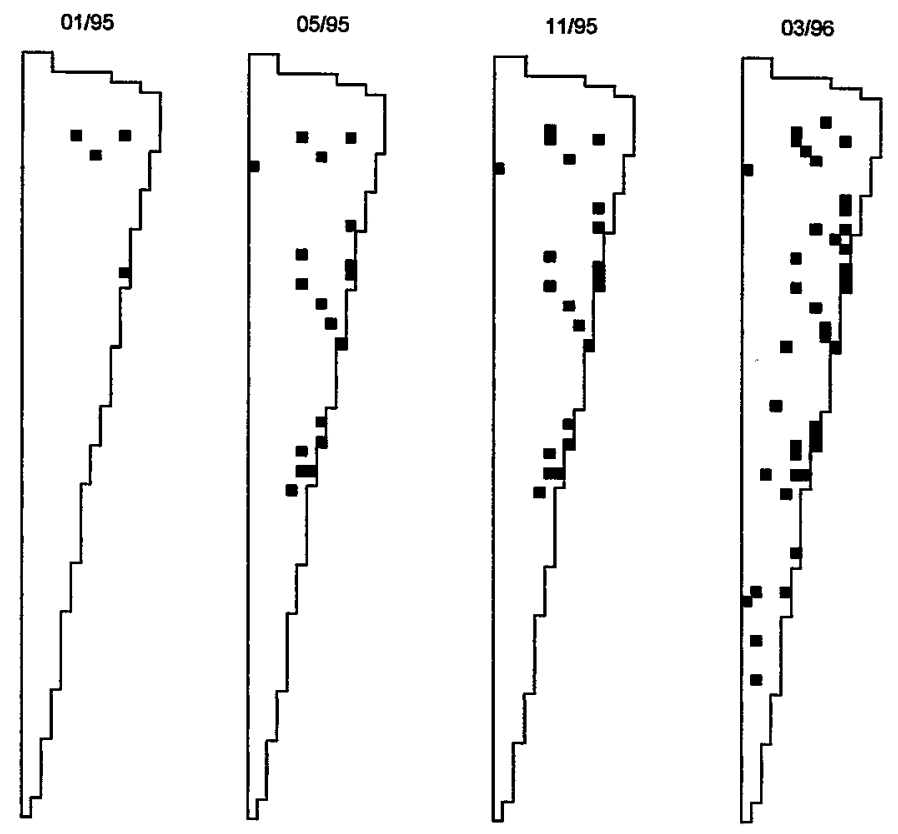

Figura 21 - Mapas de quatro avaliações $(01 / 95,05 / 95,11 / 95$ e 03/96) representativas do talhão SJ 83. Cada quadrado preto representa uma planta sintomática. 


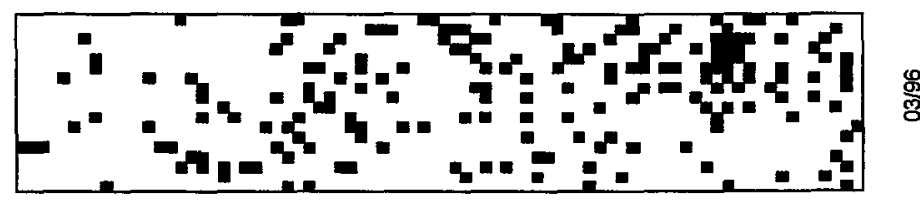

量

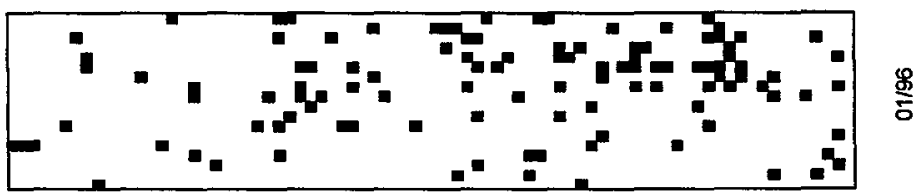

g.
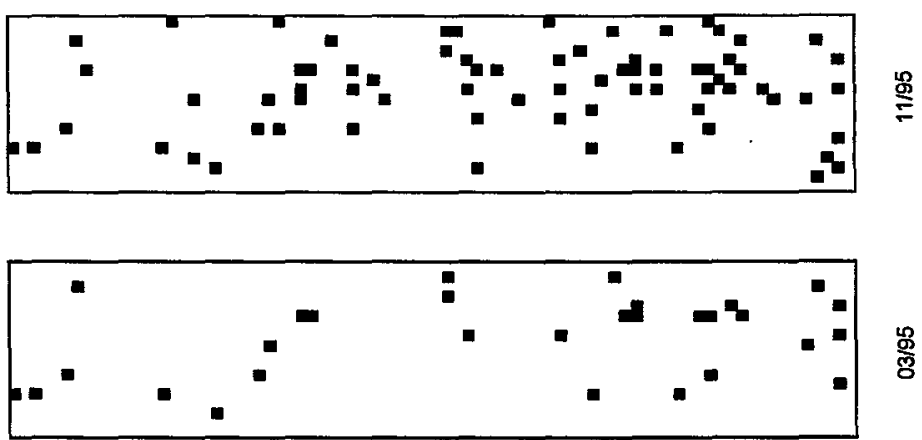

哀

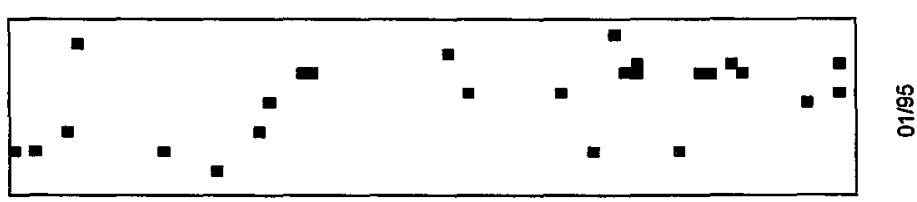

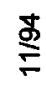

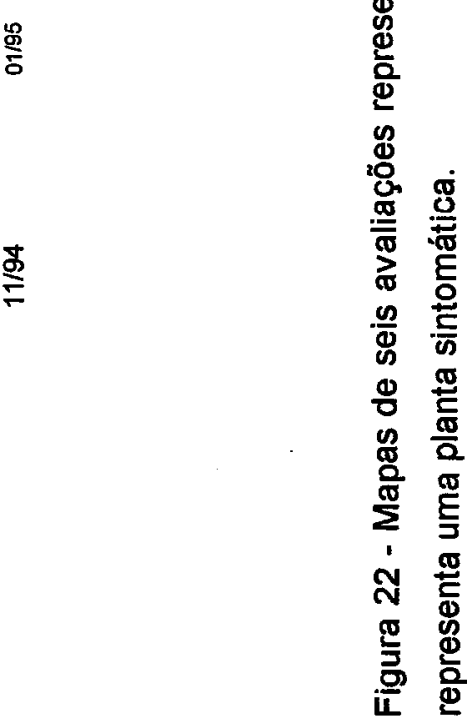



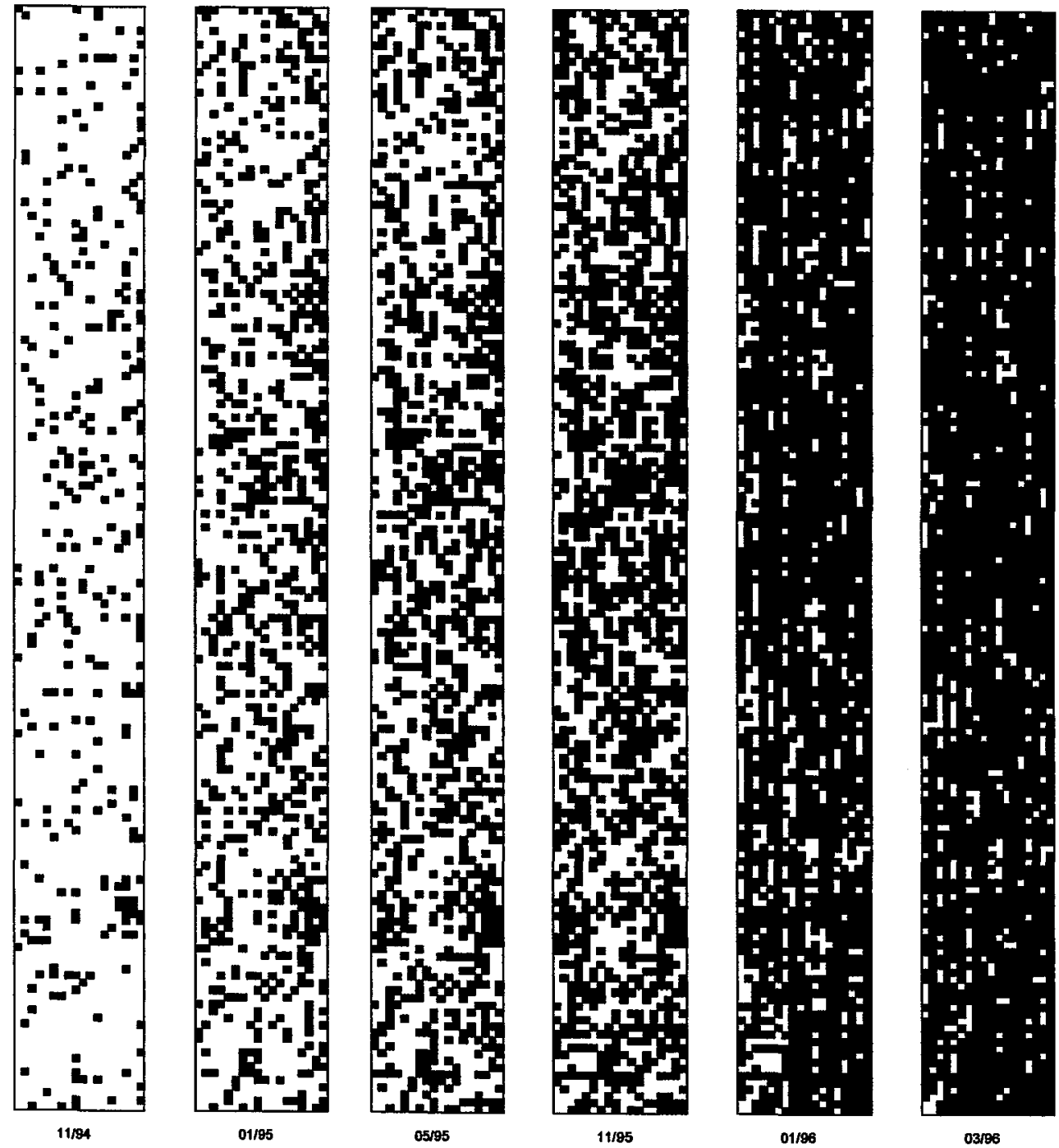

Figura 23 - Mapas de seis avaliações representativas (11/94, 01/95, 05/95, 11/95, 01/96 e 03/96) do talhão SJ 67 . Cada quadrado preto representa uma planta sintomática. 


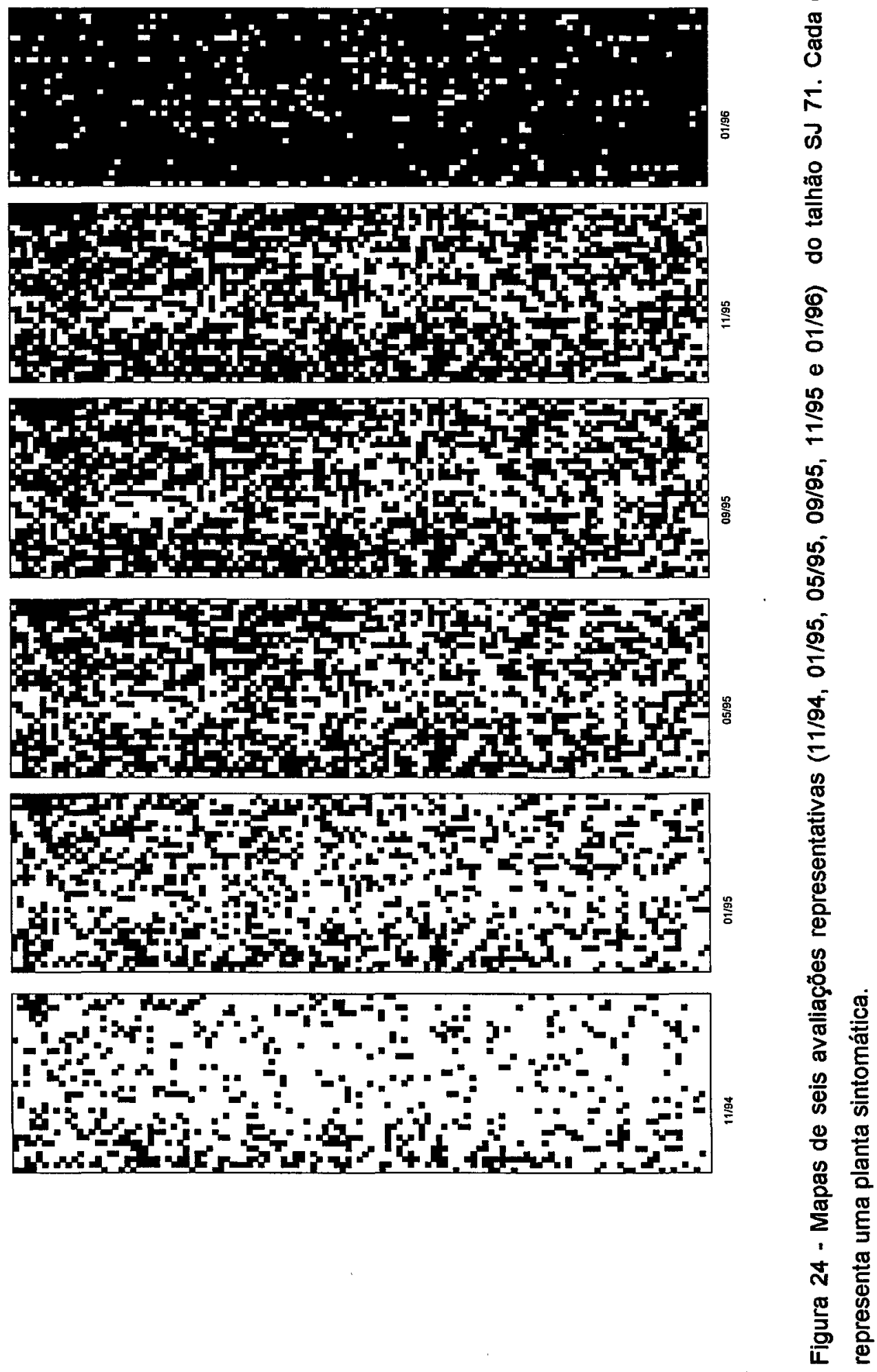




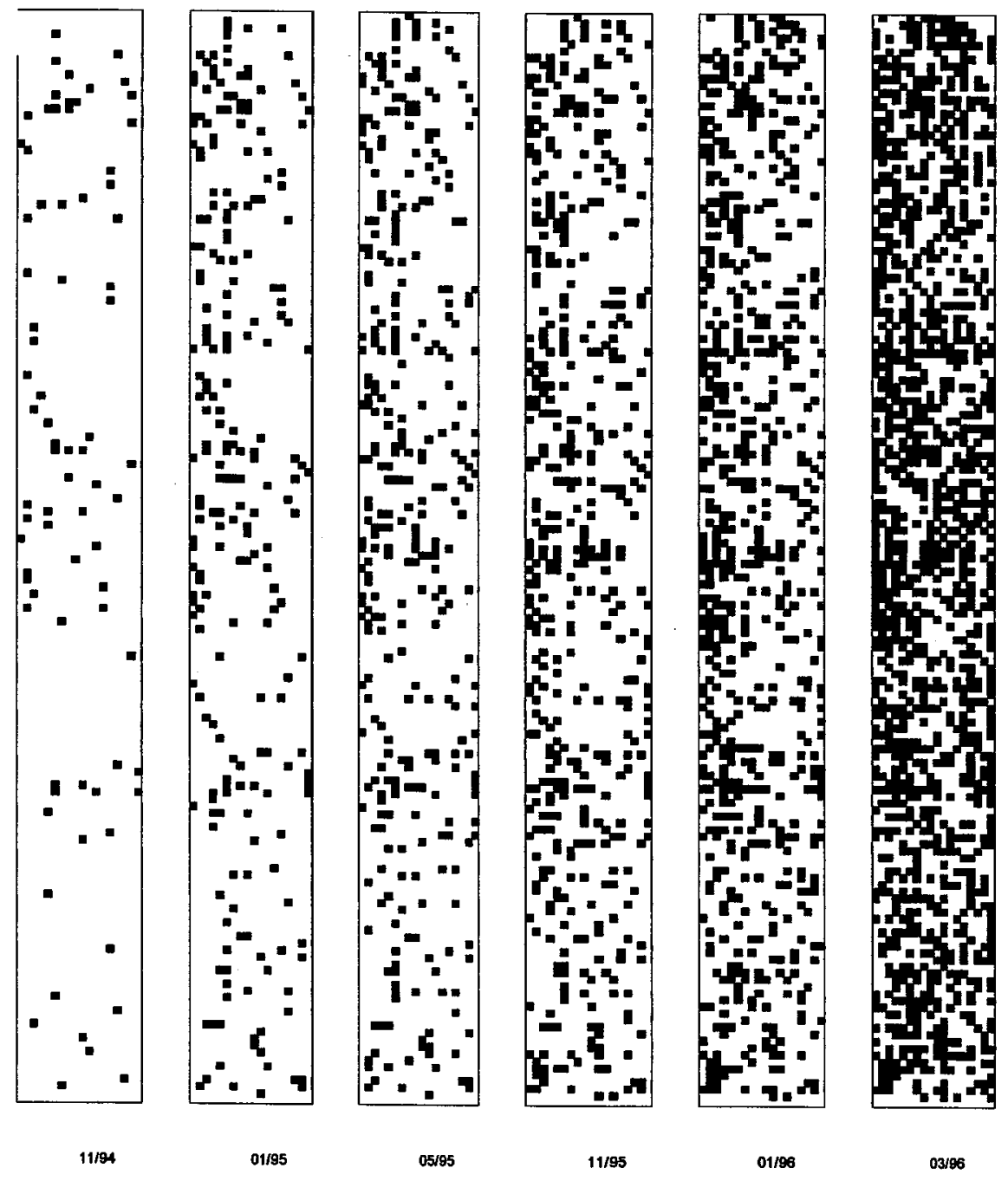

Figura 25 - Mapas de seis avaliações representativas (11/94, 01/95, 05/95, 11/95, $01 / 96$ e 03/96) do tathão $S J 75$. Cada quadrado preto representa uma planta sintomática. 

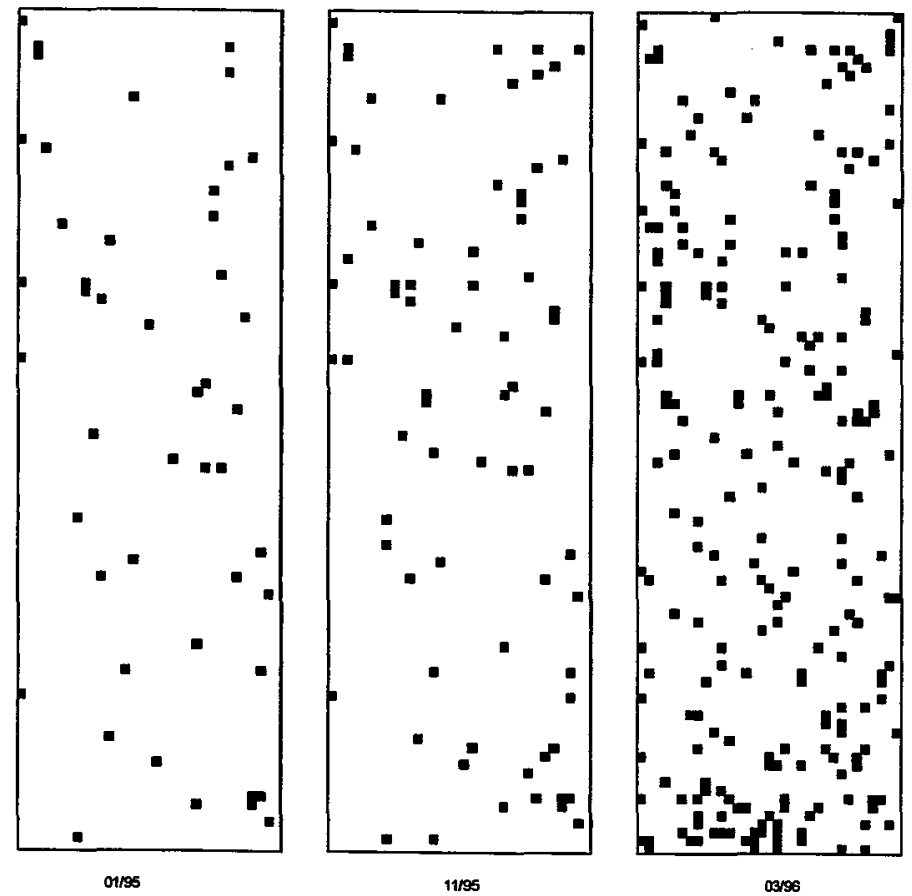

Figura 26 - Mapas de três avaliações representativas $(01 / 95,11 / 95$ e 03/96) do talhão CQH. Cada quadrado preto representa uma planta sintomática. 


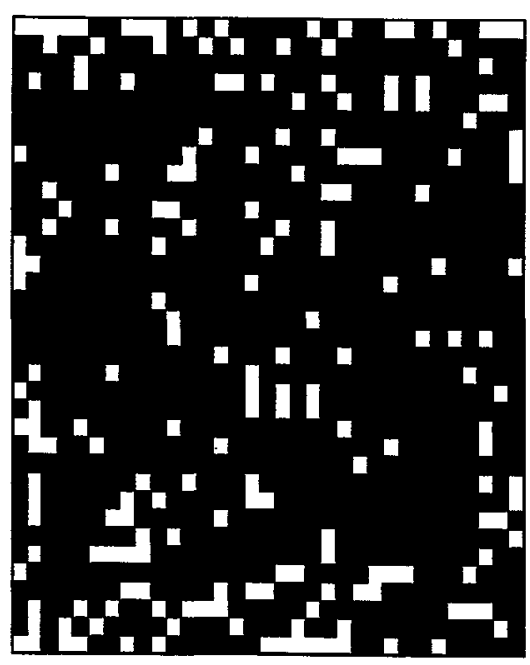

$\frac{8}{8}$

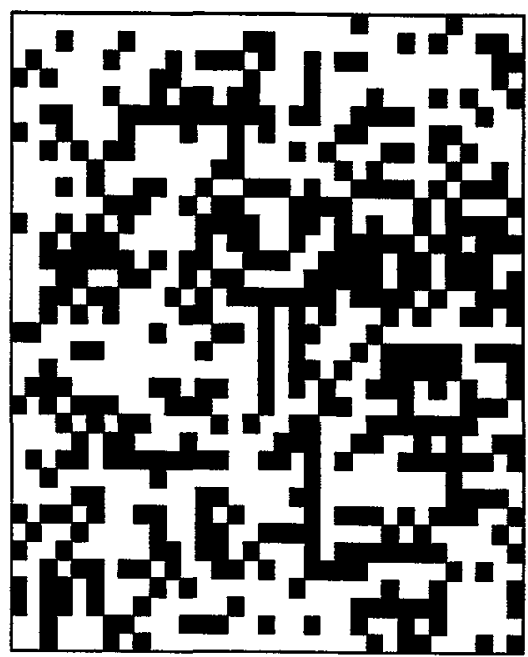

$\frac{\%}{5}$

ले

용

夏 


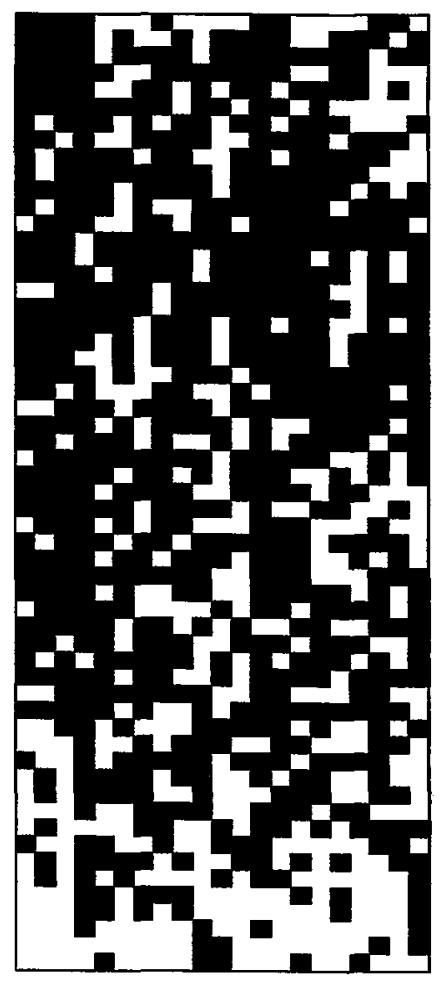

$01 / 95$

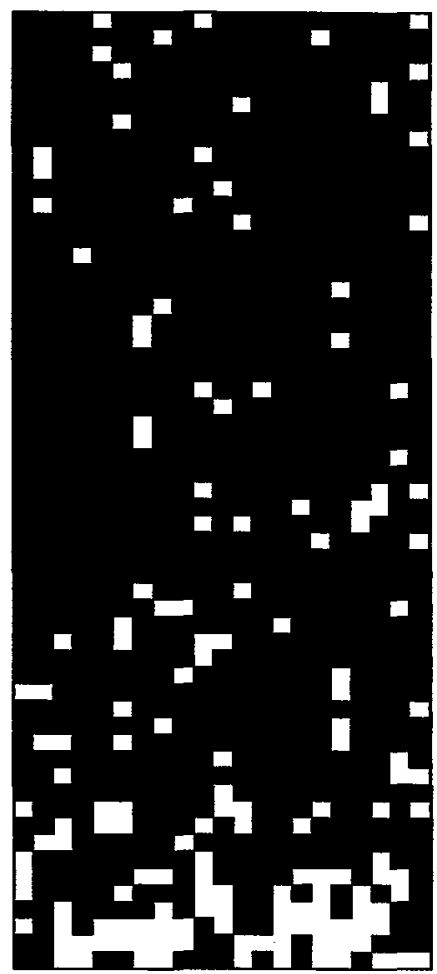

$03 / 96$

Figura 28 - Mapas da primeira (01/95) e última avaliação (03/96) do talhão CQP. Cada quadrado preto representa uma planta sintomática. 


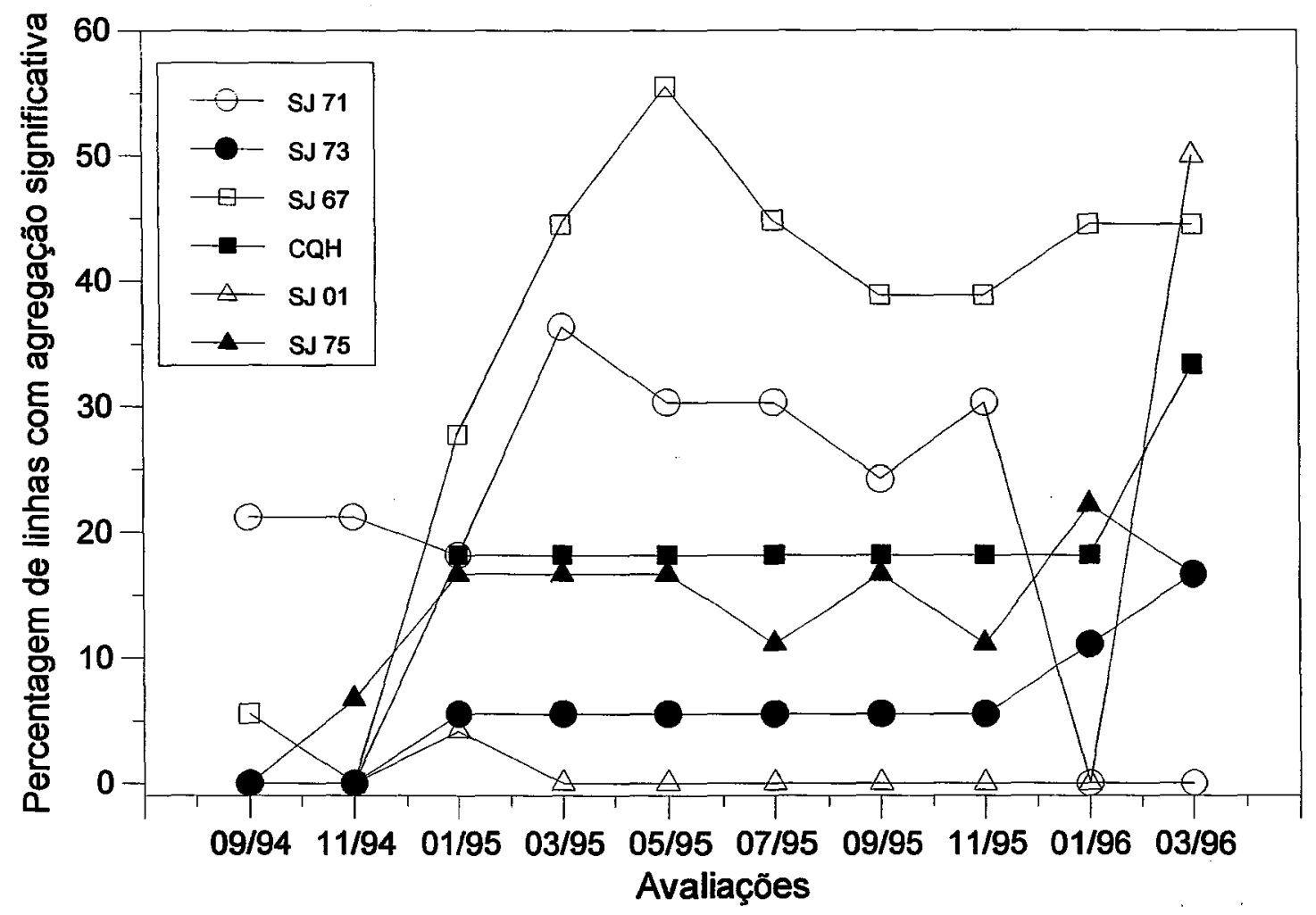

Figura 29 - Percentagem de linhas agregadas para seis talhões em dez épocas, de acordo com a análise de sequências ordinárias.

\subsubsection{Vizinho mais próximo e distância entre plantas afetadas}

Foi aplicado o teste de Clark \& Evans (CE) modificado (RIPLEY, 1979) no diagnóstico da distribuição espacial da CVC. Os resultados estão apresentados na Tabela 8. Considerando os dados de todos os talhões em conjunto, é possivel traçar linhas gerais:

i) encontrou-se que a doença se apresentou inicialmente distribuída ao acaso, as plantas doentes separadas por distâncias dentro da faixa esperada para uma situação aleatória. Essa situação foi comum para incidências abaixo de $3 \%$.

ii) com o aumento da incidência, houve diminuição no índice $C E$, o qual, ao atingir valores iguais ou inferiores a $-1,64$, indicava agregação significativa. Essa tendência à agregação foi geralmente observada para valores de incidência menores que $15 \%$. A partir dai, o indice CE tornou a aumentar, ultrapassando a faixa da 
aleatoriedade e chegando a valores superiores a 1,64 - pelo menos para os talhões SJ 67, SJ71 e SJ 75 - o que indica uma tendência à regularidade. Essa tendência pode ser admitida como confiável, tendo-se em conta que RIPLEY (1979) considera esse teste muito poderoso para apontar tal situação. Regularidade na distribuição de patógenos ou plantas doentes não é situação comum (CAMPBELL \& MADDEN, 1990). Mesmo assim, o valor mínimo de incidência no qual foi constatada homogeneidade foi de $24 \%$ (talhão SJ 75). Os talhōes CQH e SJ 83 e as sub-áreas SJ 01-2, SJ 01-3 e SJ 01-4 não apresentaram agregação de plantas doentes, segundo o índice CE.

O estudo de distância entre plantas mostrou que essa medida, assim como o indice $C E$, varia exponencial e inversamente com o tempo, em função de maiores incidências. Na Figura 30 é mostrado um exemplo dessa situação. Quando as distâncias mais frequentes foram calculadas (correspondendo à avaliação relacionada à primeira estabilização da curva de progresso prevista pelo modelo logístico de cinco parâmetros), foram obtidos os dados apresentados na Tabela 9. De maneira independente da incidência, a distância mais freqüente entre plantas doentes situou-se sempre na faixa de 1 a 8 plantas. Quando se considerou a distância em metros, obtiveram-se distâncias entre $3 \mathrm{~m}$ e $28,3 \mathrm{~m}$, dependendo do espaçamento de cada área. Embora as distâncias tenham-se estendido até quase $30 \mathrm{~m}$, a média ficou ao redor de $11 \mathrm{~m}$.

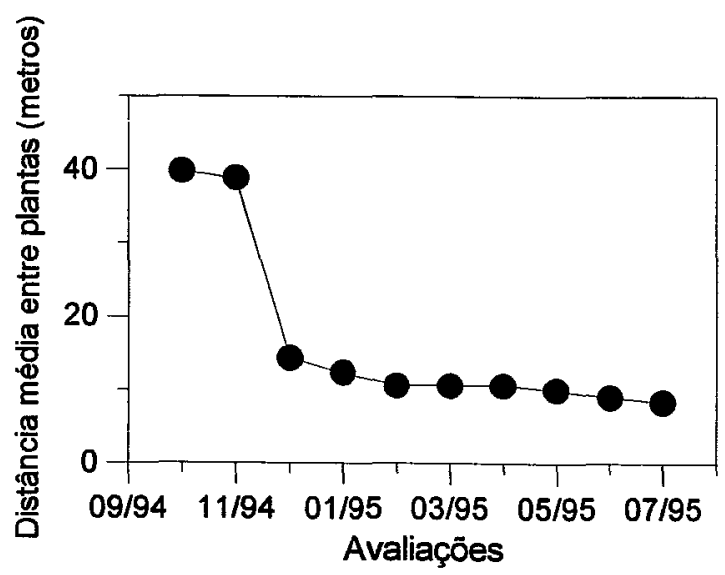

Figura 30 - Evolução da distância média (em metros) entre plantas doentes para o talhão SJ01 ao longo de dez avaliações. 
Tabela 8 - Incidência de CVC (em percentagem de plantas afetadas) e índices Clark \& Evans (CE) para onze talhões em dez épocas.

\begin{tabular}{|c|c|c|c|c|c|c|c|c|c|c|c|}
\hline Talhão & Variáveis & $09 / 94$ & $11 / 94$ & $01 / 95$ & $03 / 95$ & $05 / 95$ & $07 / 95$ & $09 / 95$ & $11 / 95$ & $01 / 96$ & $03 / 96$ \\
\hline \multirow[t]{2}{*}{ SJ 01} & Incidência & 0,42 & 0,62 & 4,51 & 6,60 & 9,93 & 9,93 & 9,93 & 11,32 & 15,07 & 19,79 \\
\hline & Indice $C^{a}$ & $-1,82$ & $-1,45$ & $-2,62$ & $-2,70$ & $-1,67$ & $-1,67$ & $-1,67$ & $-1,39$ & $-1,13$ & 1,47 \\
\hline \multirow[t]{2}{*}{ SJ 01 -2 } & Incidência & 0,06 & 0,06 & 2,4 & 5,5 & 8,5 & 8,5 & 8,5 & 9,7 & 12,1 & 17,0 \\
\hline & Indice CE & 0,37 & 0,37 & 0,41 & $-0,29$ & $-0,46$ & $-0,46$ & $-0,46$ & $-0,12$ & $-0,63$ & 0,12 \\
\hline \multirow[t]{2}{*}{ SJ 01 -3 } & Incidência & 0,06 & 0,06 & 7,2 & 9,4 & 12,2 & 12,2 & 12,2 & 13,3 & 15,6 & 20,6 \\
\hline & Indice CE & 0,40 & 0,40 & $-0,84$ & $-1,06$ & $-0,43$ & $-0,43$ & $-0,43$ & $-0,04$ & 0,06 & $-0,09$ \\
\hline \multirow[t]{2}{*}{ SJ 01 -4 } & Incidência & 3,7 & 5,1 & 13,0 & 15,3 & 19,9 & 19,9 & 19,9 & 19,9 & 25,9 & 31,0 \\
\hline & Indice CE & 0,84 & $-0,96$ & $-0,39$ & $-0,55$ & 0,18 & 0,18 & 0,18 & 0,18 & 0,62 & 1,92 \\
\hline \multirow[t]{2}{*}{ SJ 01 -5 } & Incidência & 0,04 & 0,04 & 2,7 & 4,9 & 8,0 & 8,0 & 8,0 & 8,9 & 10,7 & 17,0 \\
\hline & Indice CE & 0,16 & 0,16 & 0,02 & $-0,86$ & $-1,74$ & $-1,74$ & $-1,74$ & $-1,35$ & $-1,44$ & $-1,52$ \\
\hline \multirow[t]{2}{*}{ SJ 67} & Incidência & 2,8 & 10,6 & 28,6 & 32,9 & 38,5 & 42,4 & 46,5 & 51,9 & 79,9 & 87,9 \\
\hline & Indice CE & $-2,31$ & $-0,05$ & 12,32 & 17,86 & 24,12 & 28,78 & 34,78 & 42,68 & 87,26 & 100,4 \\
\hline \multirow[t]{2}{*}{ SJ 71} & Incidência & 11,4 & 16,9 & 31,2 & 43,5 & 47,8 & 50,4 & 53,3 & 56,5 & 91,6 & 98,0 \\
\hline & Indice CE & $-5,36$ & $-1,78$ & 13,2 & 30,1 & 36,76 & 40,78 & 44,73 & 50,48 & 113,6 & 119,9 \\
\hline \multirow[t]{2}{*}{ SJ 73} & Incidência & 0,0 & 0,02 & 1,8 & 2,1 & 2,9 & $\#$ & 3,9 & 5,0 & 7,6 & 13,6 \\
\hline & Indice $\mathrm{CE}^{\mathrm{b}}$ & $\#$ & $-0,13$ & $-3,28$ & $-3,74$ & $-2,76$ & $\#$ & $-2,77$ & $-2,05$ & $-2,83$ & $-0,14$ \\
\hline \multirow[t]{2}{*}{ SJ 75} & Incidência & 0,9 & 2,8 & 7,9 & 9,8 & 11,8 & 14,1 & 15,3 & 17,2 & 24,4 & 44,6 \\
\hline & Indice CE & $-1,51$ & $-3,54$ & $-3,19$ & $-3,37$ & $-2,48$ & $-1,11$ & $-0,75$ & 0,80 & 7,51 & 31,03 \\
\hline \multirow[t]{2}{*}{ SJ 83} & Incidência & 0,0 & 0,0 & 0,7 & 1,4 & 3,1 & $\#$ & 3,6 & 3,6 & 4,3 & 6,7 \\
\hline & Indice CE & $\#$ & $\#$ & 1,21 & 0,47 & 1,11 & $\#$ & 0,10 & 0,10 & $-0,82$ & 1,28 \\
\hline \multirow[t]{2}{*}{$\mathrm{CQH}$} & Incidência & $\#$ & $\#$ & 1,4 & 2,1 & $\#$ & 2,1 & 2,2 & 2,2 & 3,8 & 6,8 \\
\hline & Indice CE & $\#$ & $\#$ & 0,89 & 0,04 & $\#$ & 0,04 & $-0,46$ & $-0,46$ & $-0,39$ & $-1,30$ \\
\hline
\end{tabular}

${ }^{a}$ Os índices em vermelho indicam agregação e os em azul indicam regularidade significativa ao nível de $5 \%$ de probabilidade.

${ }^{\mathrm{b}}$ \# indica análise não realizada. 


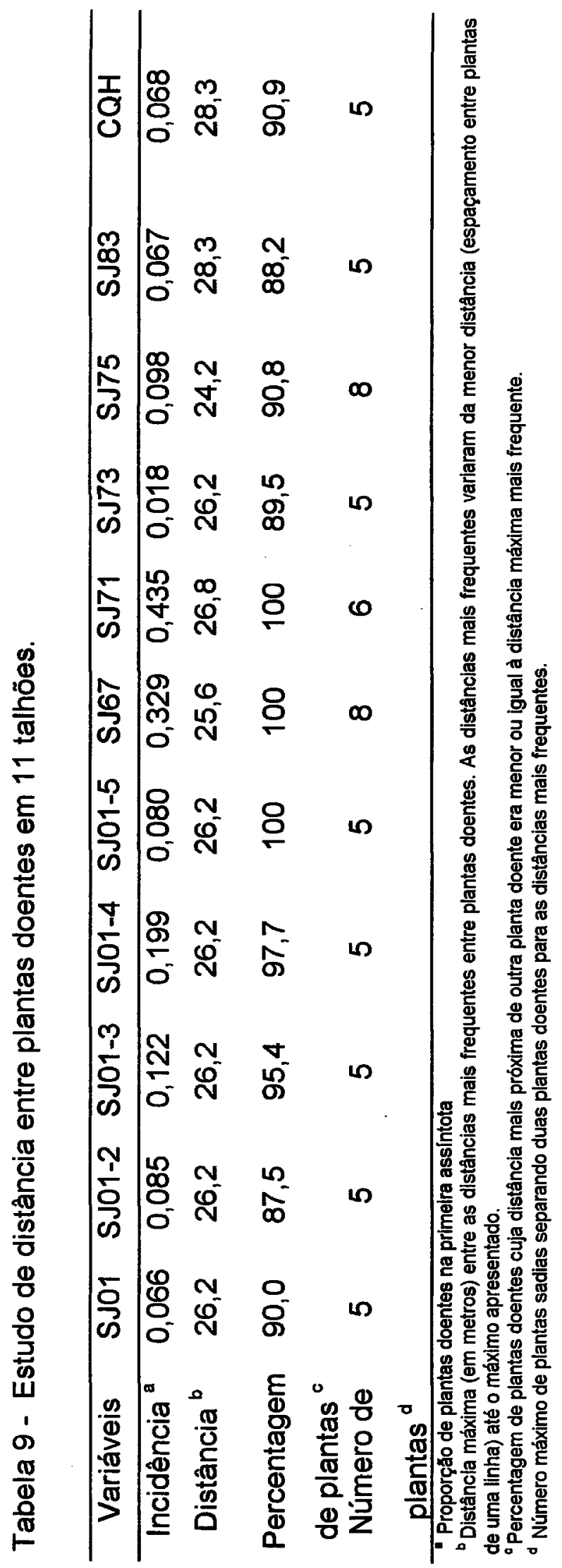




\subsubsection{Aplicação da lei de Taylor modificada (LTM)}

O uso da LTM só foi possivel nos talhões SJ 01 , SJ 67 , SJ 71 , SJ 73 , SJ 75 e no CQH. Nos demais, ou a área não pôde ser subdividida de forma conveniente (SJ 83, SJ 01-2, SJ 01-3, SJ 01-4 e SJ 01-5) ou houve arranquios e replantas de maneira extensiva (CQN e CQP). Essa situação se repetiu para todas as técnicas seguintes.

Após a regressão do logaritmo da variância observada pelo logaritmo da variância binomial estimada, foi possivel determinar os valores dos parâmetros $b \mathrm{e}$ A. Na Tabela 10 são mostrados os valores de $b$, a indicação de sua significância ou não pelo teste $\mathrm{t}$ e os valores de $A$. Nas Figuras 31 e 32 são mostradas as retas de ajuste dos dados, com os respectivos coeficientes de correlação. Usando-se a técnica de LOONEY \& GOOLEDGE Jr. (1985) foi determinado que o resíduo de todas as regressões seguiam a distribuição normal, tornando válida a realização das análises.

Quando todas as avaliaçōes de todos os talhōes foram consideradas e realizou-se a regressão pertinente (52 pares de dados), afloraram valores de $A=3,13$ e $b=1,13$, com um coeficiente de correlação $R^{2}=0,983$. $O$ valor de $b$ foi significativo ao nível de $5 \%$ pelo teste $t$. A Figura 32 mostra a reta obtida e a respectiva equação.

Tabela 10 - Valores dos parâmetros $\boldsymbol{b}$ e $\boldsymbol{A}$ da equação de ajuste à Lei de Taylor Modificada $\mathrm{e}$ significância de $b$ ao nivel de $5 \%$ de probabilidade pelo teste $t$ para seis talhões.

\begin{tabular}{|c|c|c|c|}
\hline Talhōes & $\bar{b}$ & $\bar{A}$ & Teste $t$ para $b^{a}$ \\
\hline$\overline{C Q H}$ & 1,18 & 3,46 & * \\
\hline SJ 01 & 1,15 & 4,30 & * \\
\hline SJ 67 & 1,09 & 2,49 & ns \\
\hline SJ 71 & 0,98 & 1,61 & ns \\
\hline SJ 73 & 1,10 & 2,44 & ns \\
\hline SJ 75 & 1,18 & 3,65 & * \\
\hline
\end{tabular}



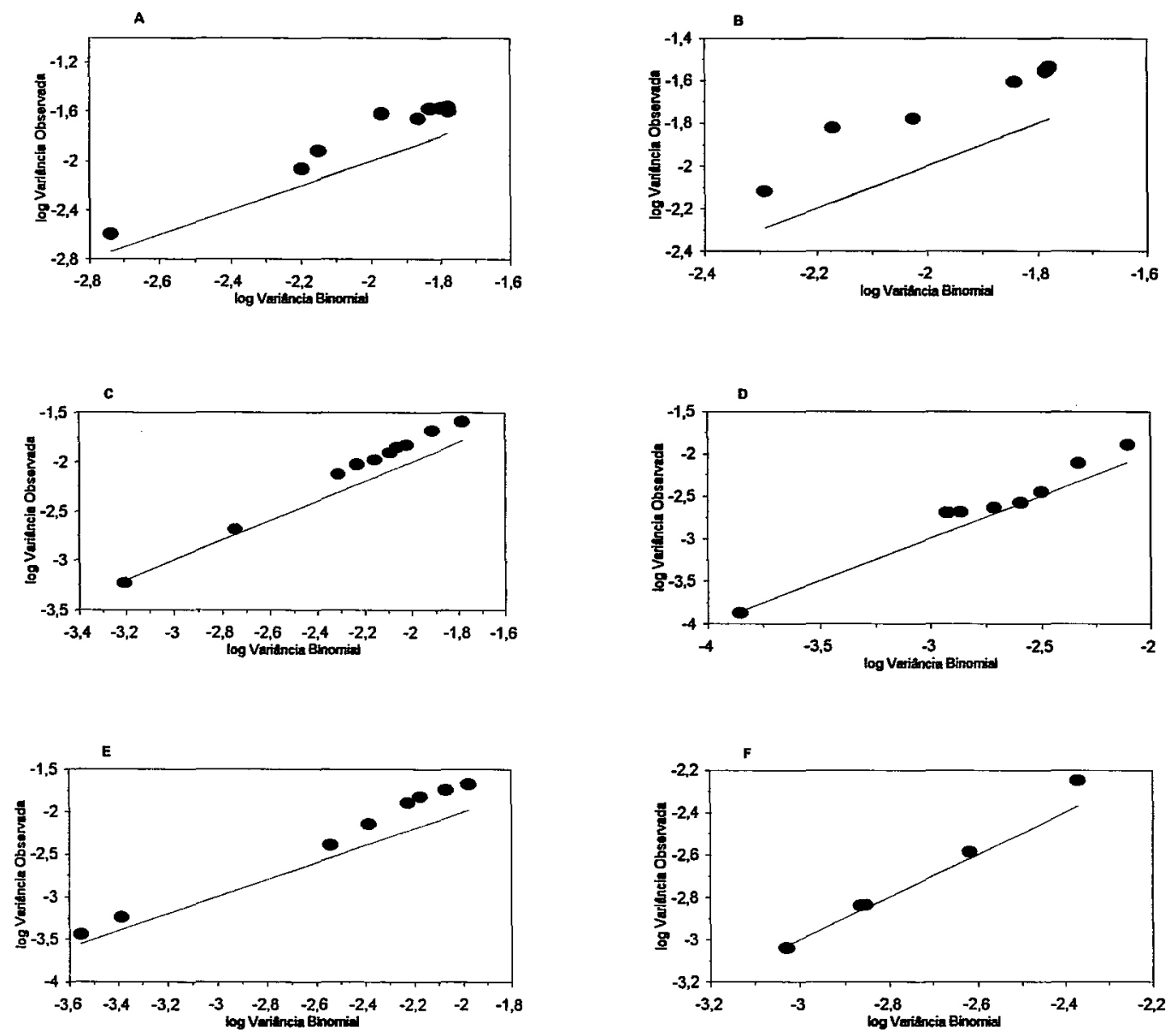

Figura 31 - Aplicação da lei de Taylor modificada. Relação entre o logaritmo da variância observada (círculos) e o logaritmo da variância binomial (linha contínua) para os talhões SJ 67(A), SJ 71(B), SJ 75 (C), SJ 73 (D), SJ 01 (E) e CQH (F). 
O estudo dos talhões individuais revelou valores de $A$ sempre maiores que 1 , assim como os valores de b, com exceção do talhão SJ 71. Entretanto, apenas nos talhões SJ 01, CQH e SJ 75 o $b$ foi estatisticamente superior a 1. Os valores do parâmetro $b$ foram usados para ponderar as variáveis dependentes na regressão nãolinear de ajuste do progresso no tempo (MADDEN \& HUGHES, 1995).

\subsection{4. Índice de dispersão (Iß)}

$\mathrm{Na}$ grande maioria dos casos 0 valor calculado de $\boldsymbol{\beta}$ foi estatisticamente superior a 1 ao nível de $5 \%$ de significância pelo teste de $\chi^{2}$, indicando que plantas doentes tendem a assumir um padrão agregado. Na Figura 33 é apresentada a evolução dos indices para cada talhão estudado.

Os valores de $1 \beta$ para o talhão SJ 67 foram sempre maiores que a unidade, variando de 1,372 na avaliação de setembro de 1994 a 2,239, na de janeiro de 1996. A análise de correlação desses valores pela incidência indicou uma relação direta e significativa $\left(R^{2}=0,51\right)$ a $5 \%$ de probabilidade. Por outro lado, para o talhão SJ 75 a relação entre valores de I $\beta$ e incidência não foi significativa $\left(R^{2}=0,32\right)$. $O$ menor valor de I $\beta$ ocorreu na primeira avaliação (09/94) e o pico, em janeiro de 1996. Apenas em mais uma área (SJ 73) a relação entre valores de $\mid \beta$ e incidência não foi significativa $\left(R^{2}=0,21\right)$. Nesse caso, o valor mais baixo de $\mid \beta$ se deu na primeira avaliação com plantas doentes (novembro de 1994), mas o valor mais alto foi encontrado no levantamento logo em seguida, em janeiro de 1995. Após isso, houve uma variação de valores altos e baixos. Também apenas nesse talhão, foi observada uma variação sazonal no I $\beta$. Aparentemente, os índices foram maiores nas avaliações de primavera e verão e menores nas de outono e inverno. No $\mathrm{CQH}$, a relação entre incidência e I $\beta$ foi alta e significativa $\left(R^{2}=0,94\right)$; nesse talhão o maior valor de $\beta$ $(0,978)$ ocorreu na primeira avaliação e o pico $(1,326)$ se deu na última, em março de 1996. No SJ 01, o menor I $(1,279)$ ocorreu em setembro de 1994 (primeiro levantamento) e o maior $(2,253)$, em novembro de 1995 (antepenúltima avaliação). Apesar da relação entre $I \beta$ e incidência ter sido direta e significativa $\left(R^{2}=0,61\right)$, os 
valores de I $\beta$ tenderam a cair nas últimas avaliações (janeiro e março de 1996). Apenas no SJ 71 a relação $\mid \beta \times$ incidência foi inversamente proporcional e significativa $\left(R^{2}=0,62\right)$. De fato, o valor mais alto de $\mid \beta$ se deu na primeira avaliação $(2,232)$ e o menor valor $(1,496)$, na última avaliação.

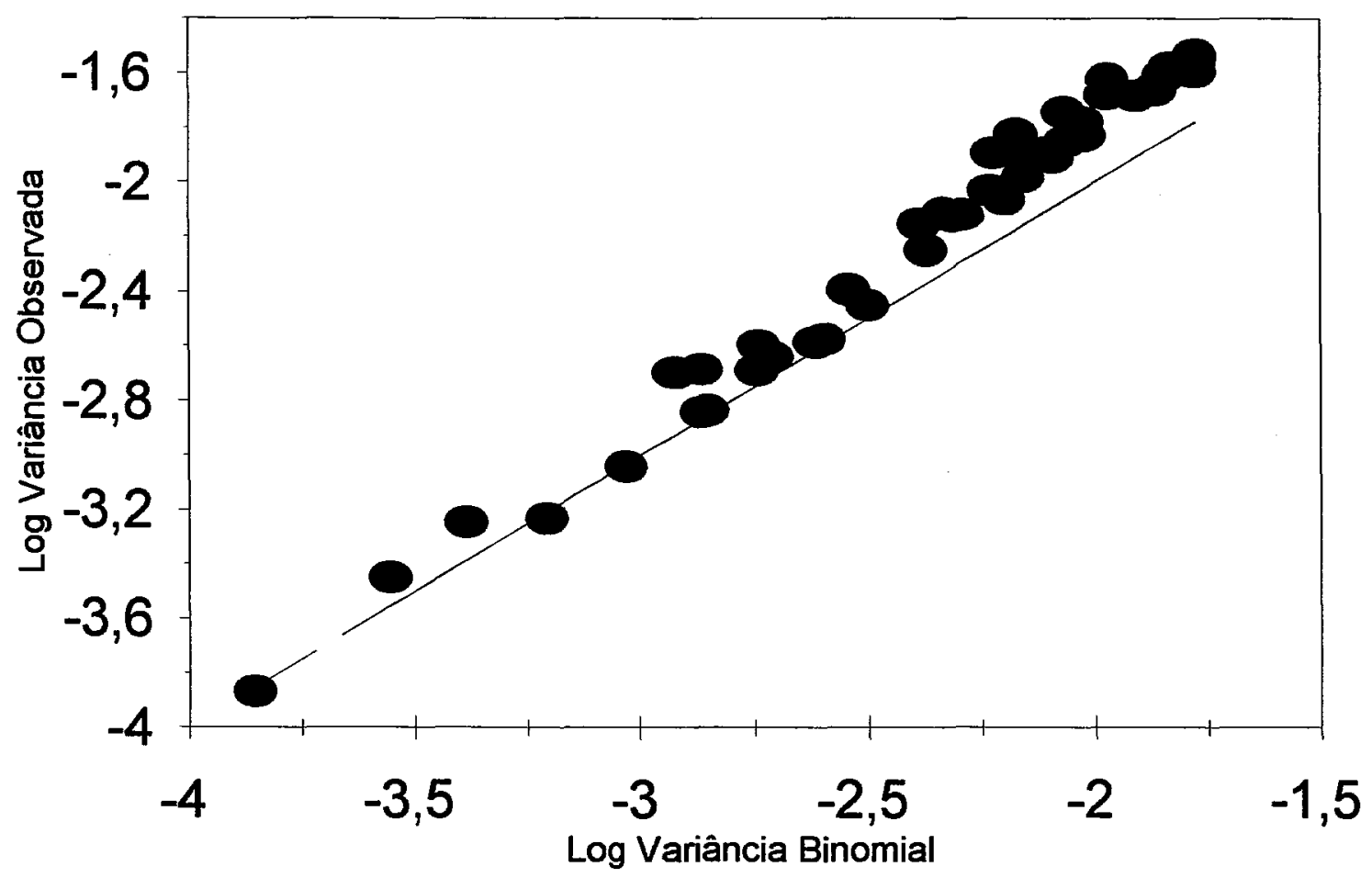

Figura 32 - Aplicação da lei de Taylor modificada. Relação entre o logaritmo da variância observada (círculos) e o logaritmo da variância binomial (linha contínua) para as informações agrupadas dos seis talhões, totalizando 52 pares de dados. 

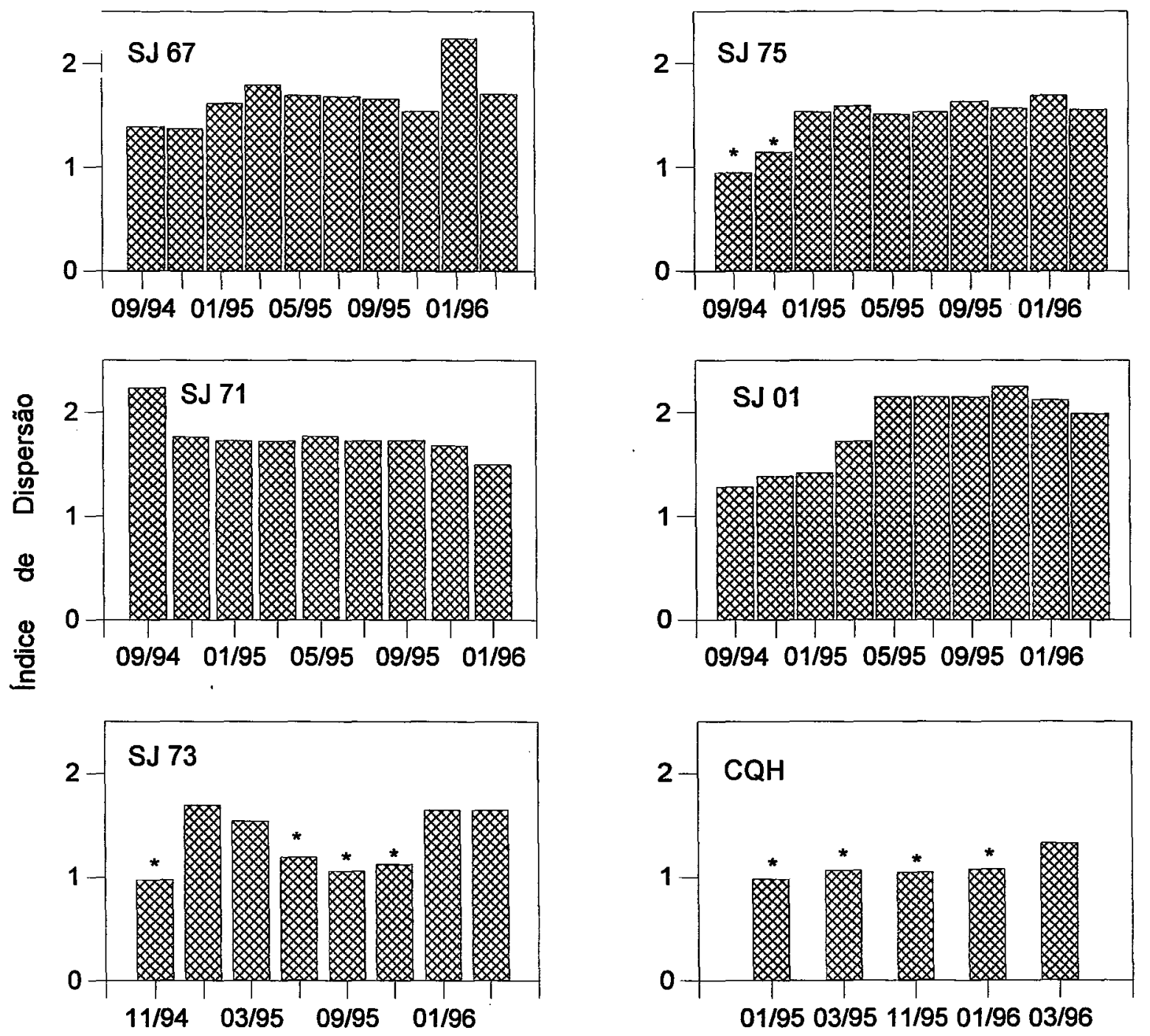

Datas das Avaliações

Figura 33 - Evolução dos valores do índice de dispersão (Iß) para os talhões SJ 67, SJ 71, SJ 75, SJ 73, SJ 01 e CQH. O índices marcados com * não diferiram estatisticamente da unidade. 


\subsubsection{Determinação de áreas isópatas (Al)}

Para essa análise não há determinação de índices ou informações puramente matemáticas. Os mapas gerados e apresentados nas Figuras 34 a 40 representam a situação da doença em cada época e cada área isópata (Al) denota os locais de incidência semelhante.

Para o talhão SJ 01 , inicialmente constatou-se um foco no setor sudeste, representado por Als concêntricas naquela região e um outro, mais discreto, no setor noroeste (Figura 34b). Aparentemente, a primeira área dirigiu a expansão da doença nos sentidos Leste/Oeste e Sul/Norte, enquanto a segunda teve uma maior influência no caminhamento da doença no sentido Norte/Sul (Figura 34e,f). No talhão SJ 73, observou-se uma maior concentração de plantas doentes no setor sudoeste. Essa concentração foi interna, embora próxima da sua borda oeste (Figura 35), que faz fronteira com o talhão SJ 75 (Figura 6). Apenas na última avaliação foi detectada a formação de um novo foco, desta vez no setor noroeste. No talhão SJ 67 , a área com maior quantidade de plantas doentes se localizou no setor sul (vizinho do talhão SJ 71 - Figura 6), e foi caracterizada por Als com maiores médias que o restante do pomar (Figura 36). Essa situação foi detectada desde o inicio da epidemia, embora seja visível em todas as épocas. Não houve detecção de focos secundários importantes, muito embora aquele formado no setor norte tenha atingido grandes proporções. No talhão SJ 71 foram detectadas duas áreas com maior concentração de plantas doentes. A primeira delas encontrava-se no setor sudeste e a segunda, maior que a primeira, espalhada em todo o setor norte do talhão (Figura 37). $\mathrm{O}$ primeiro setor faz fronteira com o talhão SJ 75 e o segundo, com o SJ 67 (Figura 6). Aparentemente foram essas áreas que influenciaram o progresso da CVC nesse talhão, já que não foram observados focos secundários detectáveis pela análise de Als. No SJ 75, a situação de maior concentração de plantas doentes nas bordas se repetiu, desta vez localizada no setor nordeste do talhão (Figura 38), setor que faz fronteira com a face sudeste do SJ 71 (Figura 6). A partir daquela zona, a doença se disseminou nas direções Sul e Sudoeste. No talhão CQH, nas primeiras avaliações, não se observou formação de concentrações de plantas doentes (Figura 39a,b). Tal fato se deu apenas na última avaliação, quando foram detectadas três zonas desse 
tipo (Figura 39c). A primeira e maior foi observada na borda noroeste, que faz divisa com o talhão CQN, também com CVC (Figura 7). As outras duas áreas ficaram nos setores norte e oeste do talhão e, aparentemente, são menos importantes. Nos talhões CQN e CQP não foram observadas concentrações de plantas doentes nas bordas das áreas. Ao contrário, as Als de maior média localizaram-se no centro dos talhões (Figuras 40). No talhão SJ 83 não foi possivel realizar a análise de áreas isópatas devido à irregularidade das linhas de plantio. Apesar disso, pode-se notar uma maior concentração de plantas doentes na porção mais irregular da área (Figura 21), que faz divisa com um riacho e uma mata ciliar (Figura 5).

Em todas glebas, mesmo tendo sido observada a existência de áreas com maior concentração de plantas doentes, pode-se ver (Figuras 21 a 28) que 0 aparecimento dessas plantas não se deu de maneira organizada. No SJ 73 , por exemplo, apesar da maior concentração de plantas doentes no setor sudoeste (Figura 35), as primeiras plantas afetadas não foram constatadas nesse setor (Figura 22). Nos talhöes SJ 67, SJ 71 e SJ 75 (Figuras 23, 24 e 25), por outro lado, desde a primeira avaliação, podiam ser encontradas árvores com CVC em todos os setores das glebas.

As direçōes predominantes da disseminação da CVC para cada talhão, apresentadas na Tabela 11, foram estabelecidas em função da ocorrência de Als de maior média. Quando ocorreram, assumiram direção Norte/Sul (talhão SJ 75), Sul/Norte (talhão SJ 67) ou Sudeste/Noroeste (talhões CQH, SJ 71 e SJ 73). Direções secundárias só foram observadas nos talhões CQH (Sudoeste/Nordeste e Norte/Sul) e SJ 71 (Norte/Sul). 


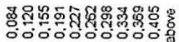

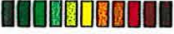
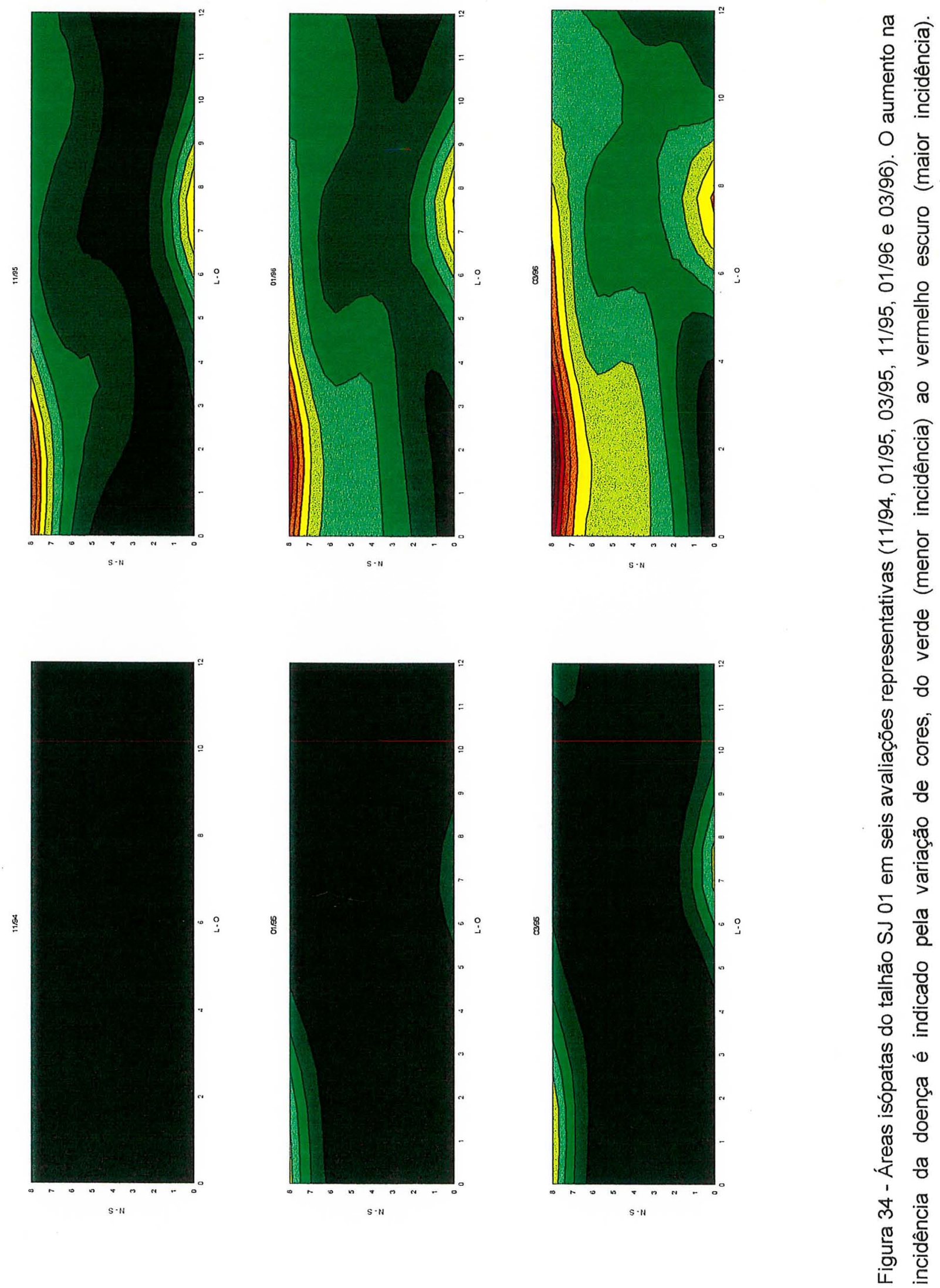

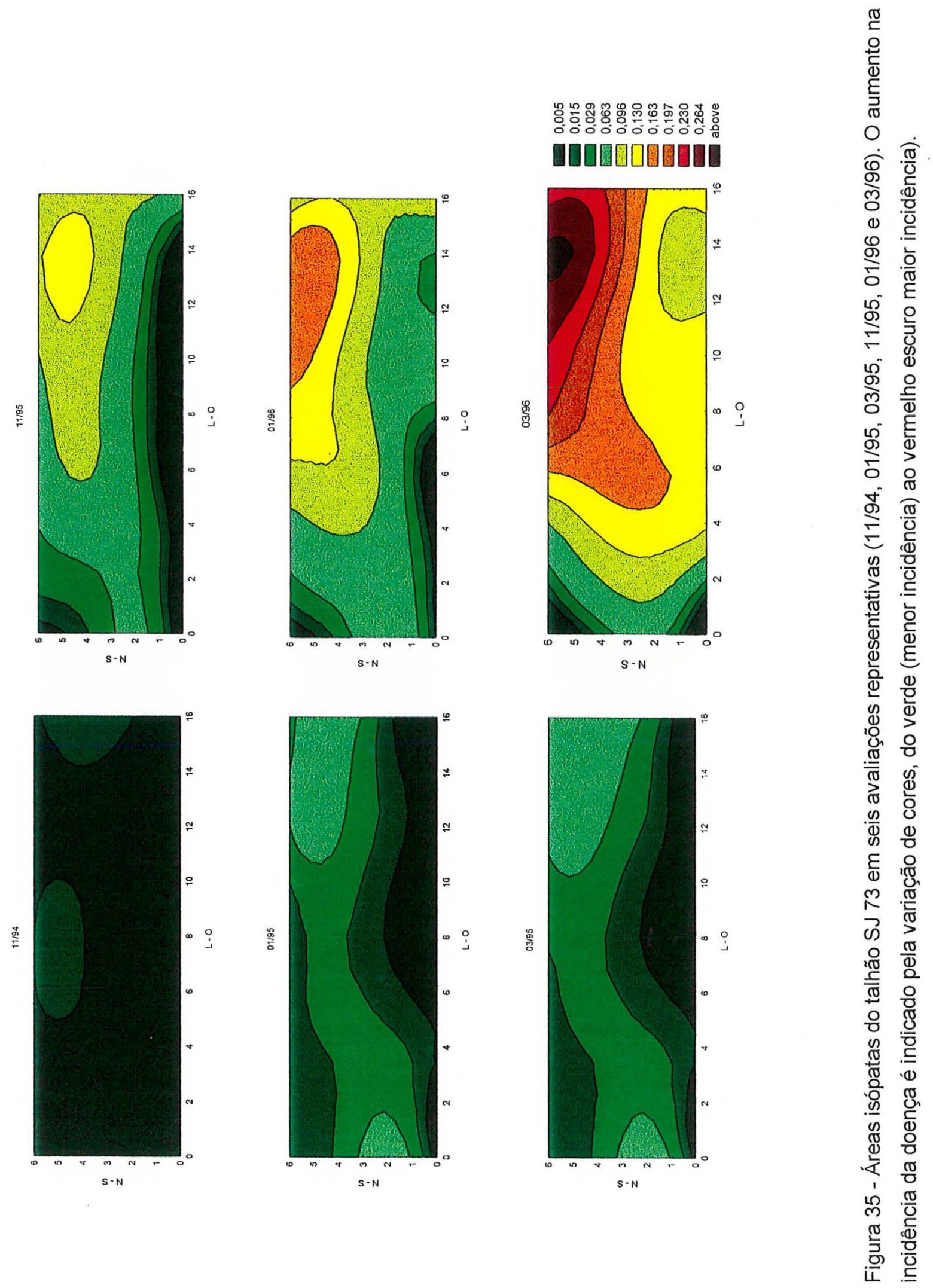


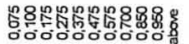

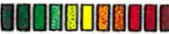
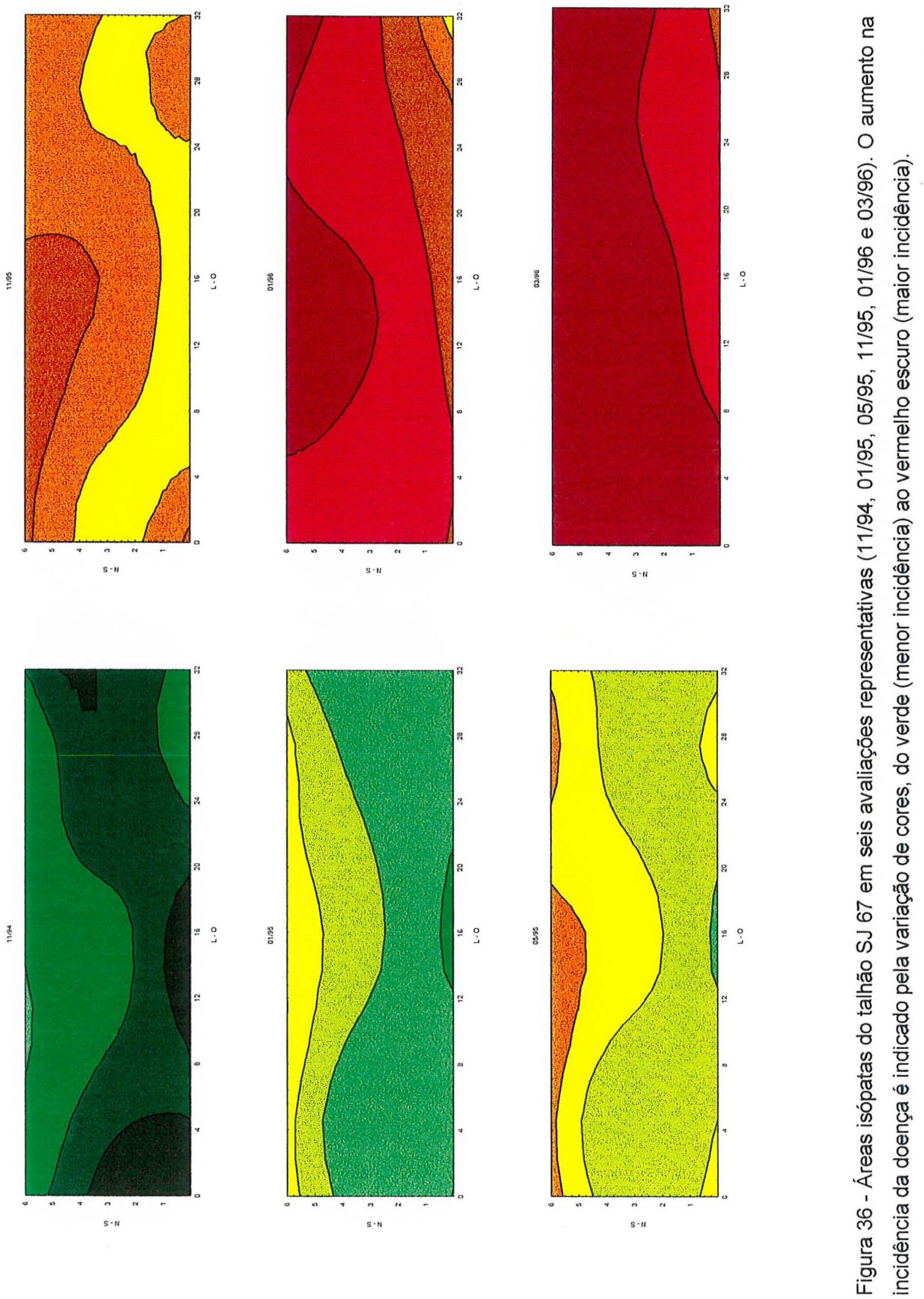

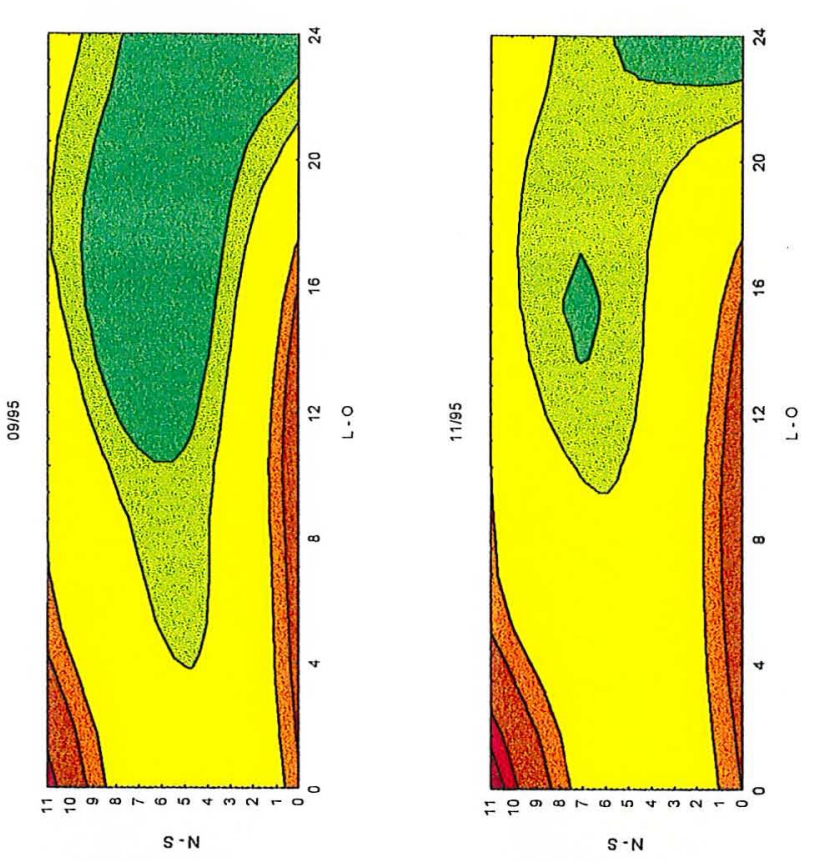

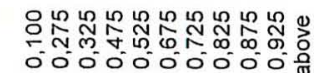

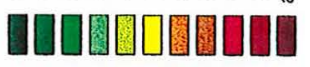

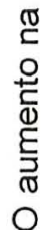
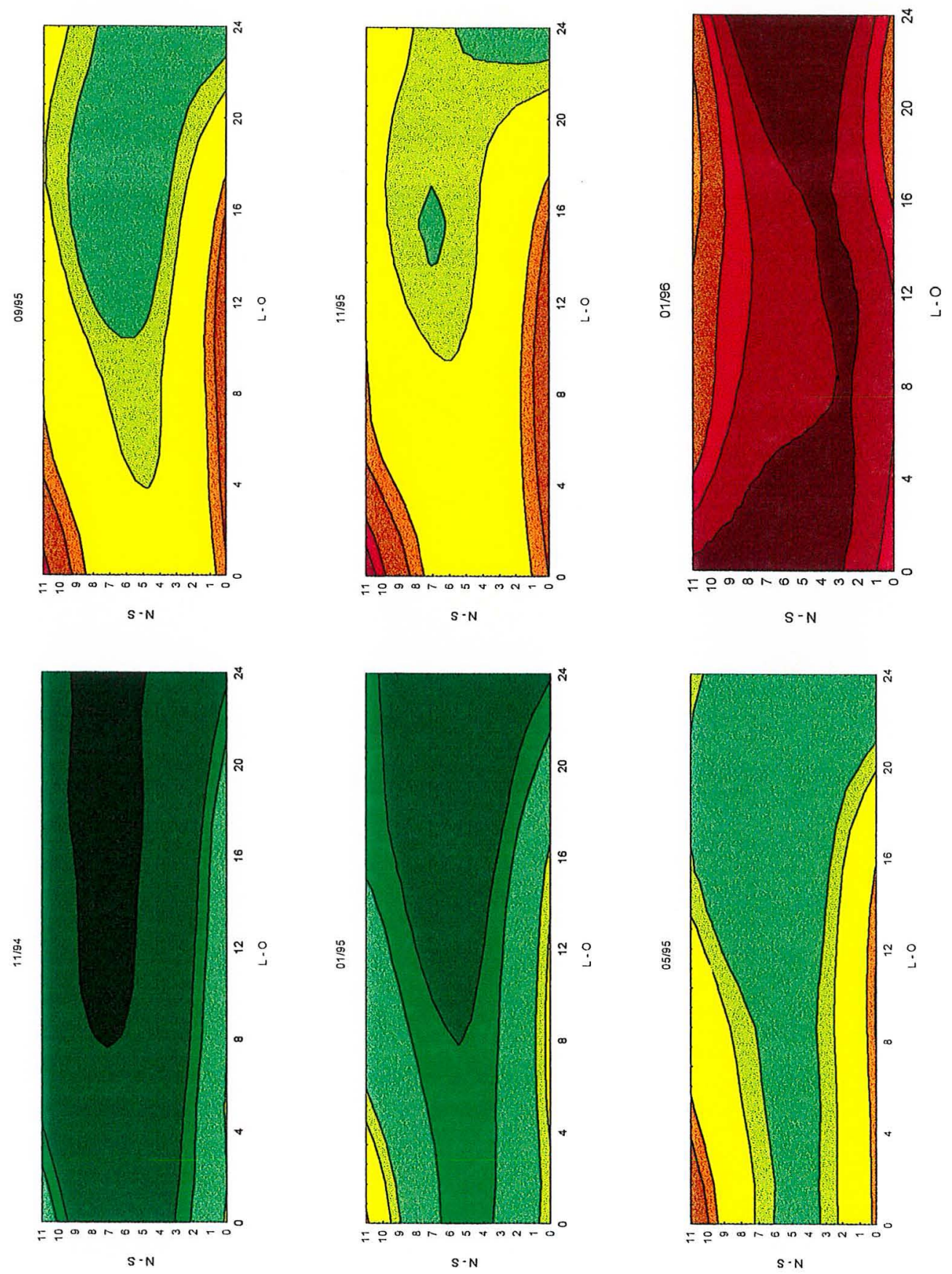

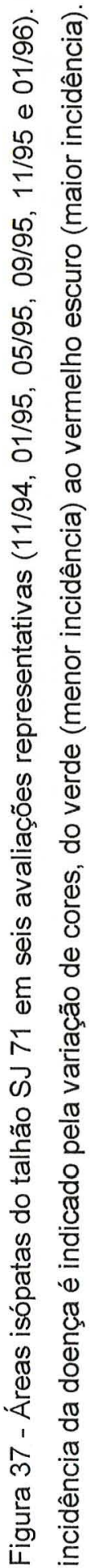



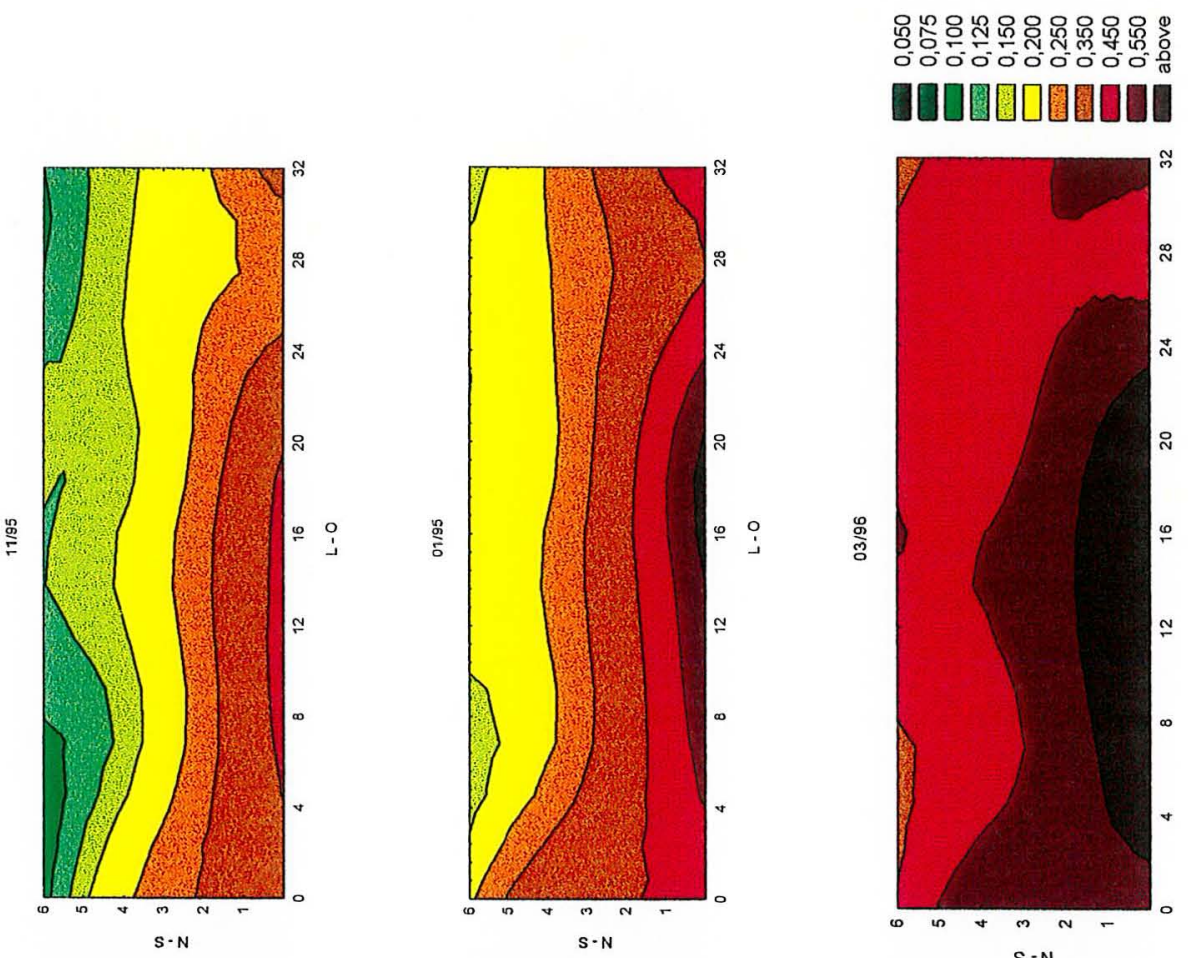

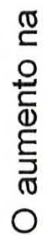
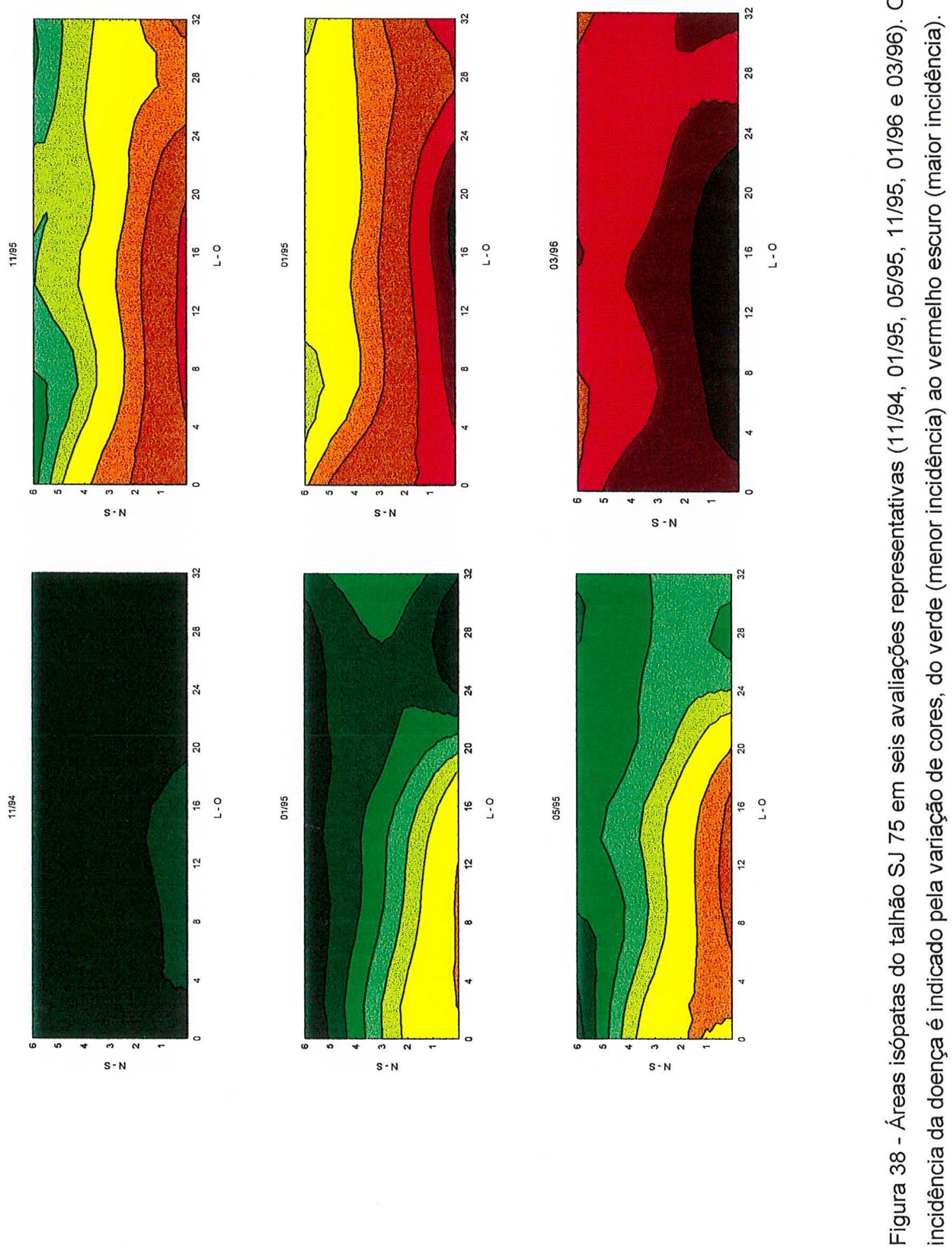
$01 / 95$

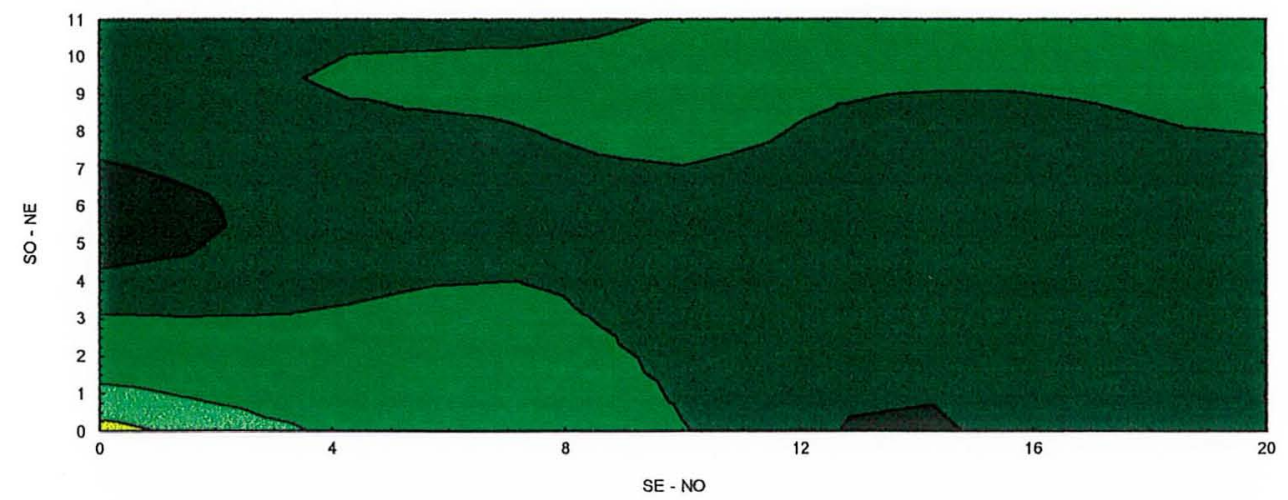

$11 / 95$

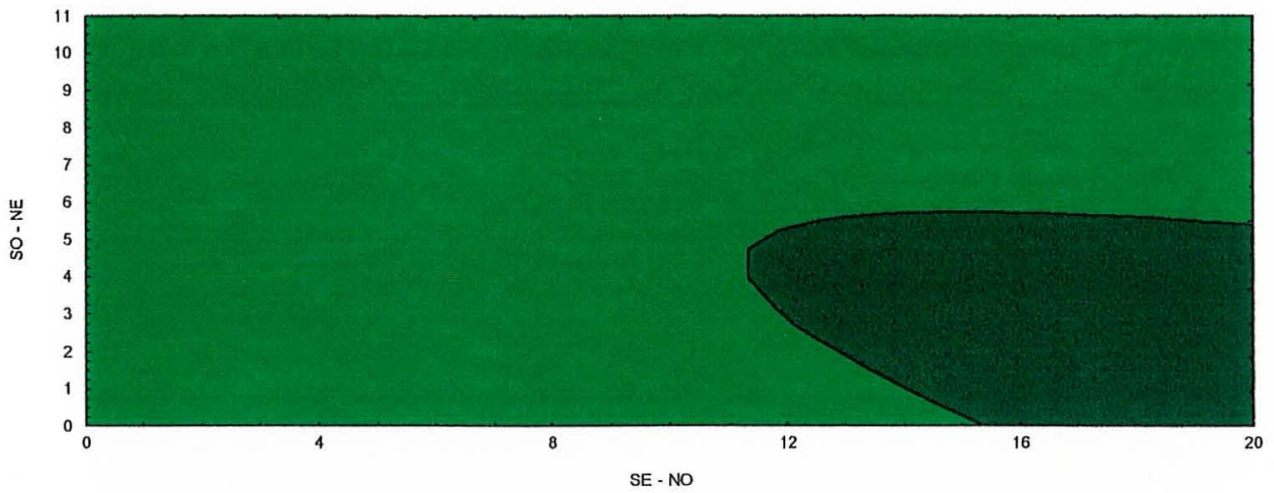

03/96

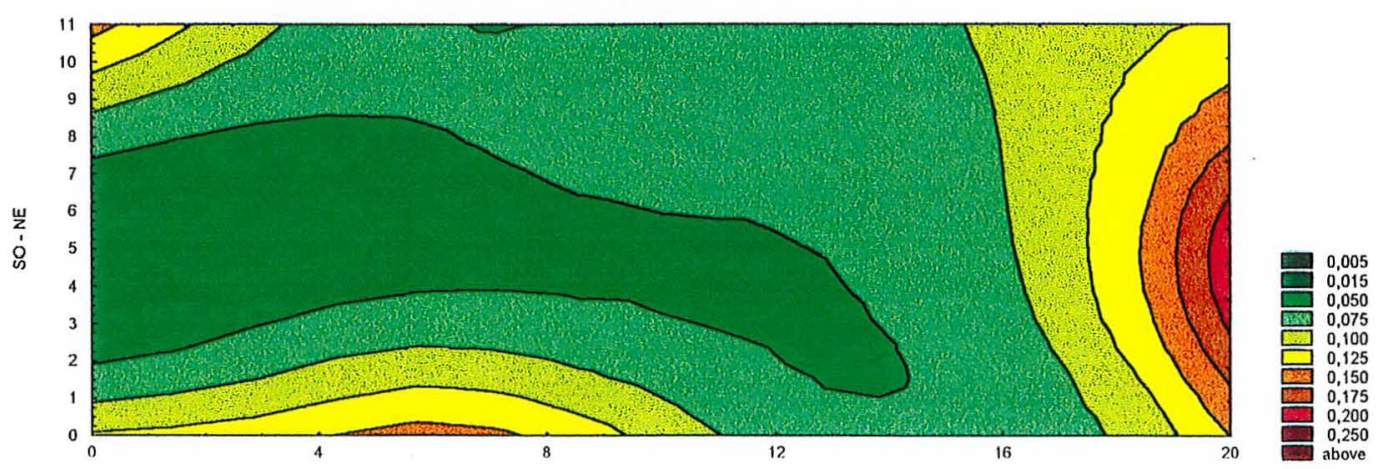

Figura 39 - Áreas isópatas do talhão CQH para três avaliações representativas $(01 / 95,11 / 95$ e 03/96). O aumento na incidência da doença é indicado pela variação de cores, do verde (menor incidência) ao vermelho escuro (maior incidência). 

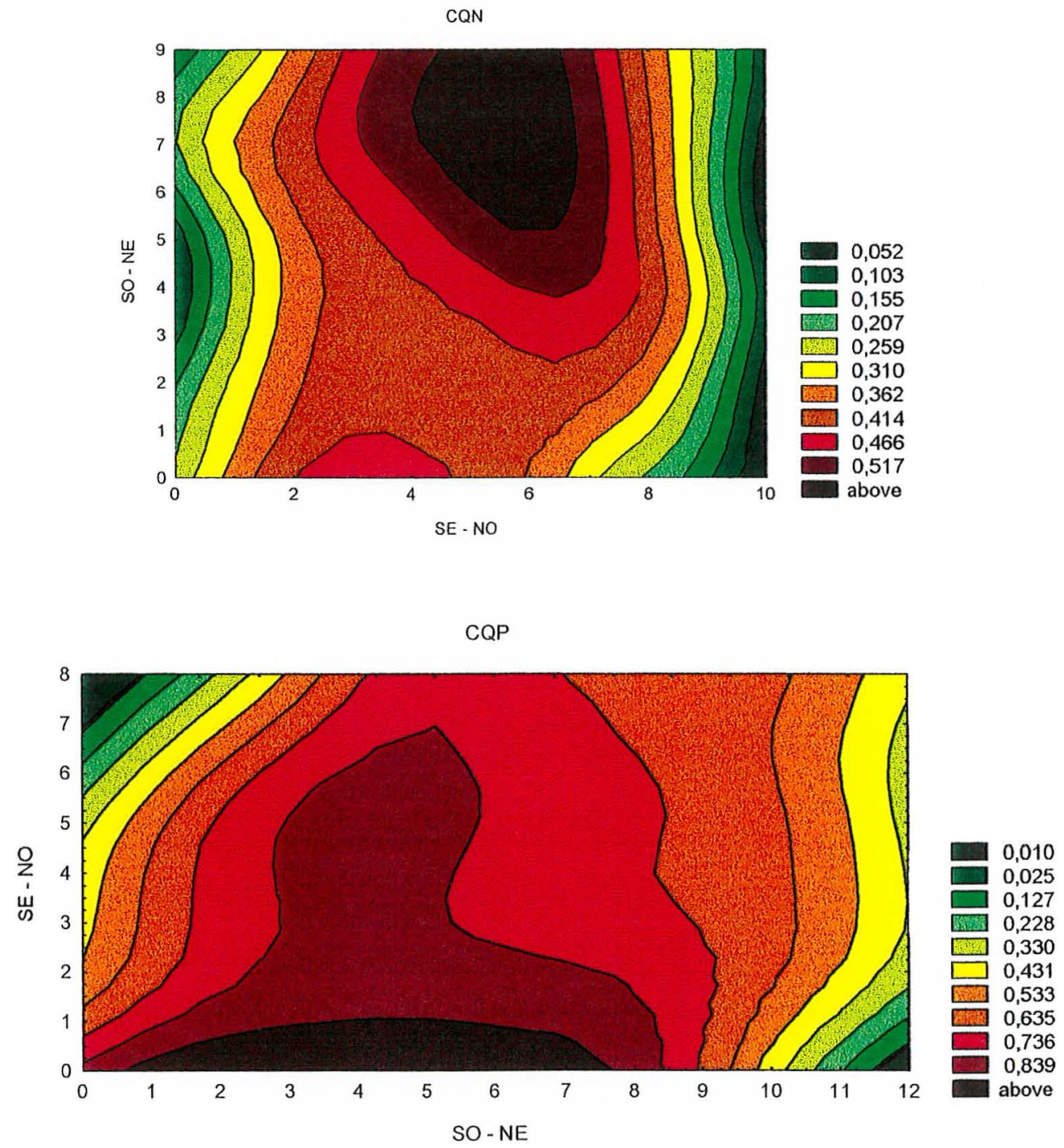

Figura 40 - Áreas isópatas dos talhões CQN e CQP para a última avaliação (03/96). O aumento na incidência da doença é indicado pela variação de cores, do verde (menor incidência) ao vermelho escuro (maior incidência). 
Tabela 11 - Direções predominantes da disseminação da CVC em seis talhões, em relação aos pontos cardeais. O sinal \# indica ausência de direção predominante.

\begin{tabular}{ccc}
\hline Talhão & Direção Principal & Direções secundárias \\
\hline CQH & Sudeste/Noroeste & Sudoeste/Nordeste e \\
CQP & $\#$ & Norte/Sul \\
CQN & $\#$ & $\#$ \\
SJ 67 & Sul/Norte & \# \\
SJ 71 & Sudeste/Noroeste & Norte/Sul \\
SJ 73 & Sudeste/Noroeste & $\#$ \\
SJ 75 & Norte/Sul & $\#$ \\
SJ 83 & $\#$ & $\#$ \\
\hline
\end{tabular}

\subsubsection{Análise de dinâmica e estrutura de focos (ADEF)}

\subsubsection{Número de Focos}

Como a quantidade de plantas em cada área era diferente, o número de focos teve que ser padronizado. Os dados puderam ser então avaliados em conjunto, como número de focos por 1000 plantas (NFM). O mesmo procedimento foi adotado para as reboleiras (NRM). Observou-se que o padrão das curvas de NRM e número de focos unitários por 1000 plantas (NF1M) foi semelhante (Figura 41a). Entretanto, a inclinação inicial da curva de NF1M é muito mais acentuada que a de NRM.

O pico de número total de focos por 1000 plantas (NFM), foi observado quando a proporção de plantas afetadas estava entre 0,2 e 0,3 (Figura 41b). A coalescência de focos foi constatada a partir da ocorrência do pico de NFM. Além da redução no número de focos, o aumento no seu tamanho (Figura 42) é a outra evidência do fenômeno de agrupamento de focos. Dentro do período estudado, apenas os talhões SJ 67 , SJ 71 e SJ75 apresentaram ocorrência de pico de NFM 
(Figura 43). Para os outros talhões não houve pontos marcantes que os diferenciassem do observado para aqueles. Ao contrário do SJ 67 e SJ 71, o SJ 75 não apresentou pico abrupto de NFM.

Foi observada também uma relação inversa entre percentagem de focos unitários e proporção de plantas doentes (Figura 44). Isso ocorreu mesmo para incidências inferiores a $20 \%$, quando ainda não havia coalescência de focos.
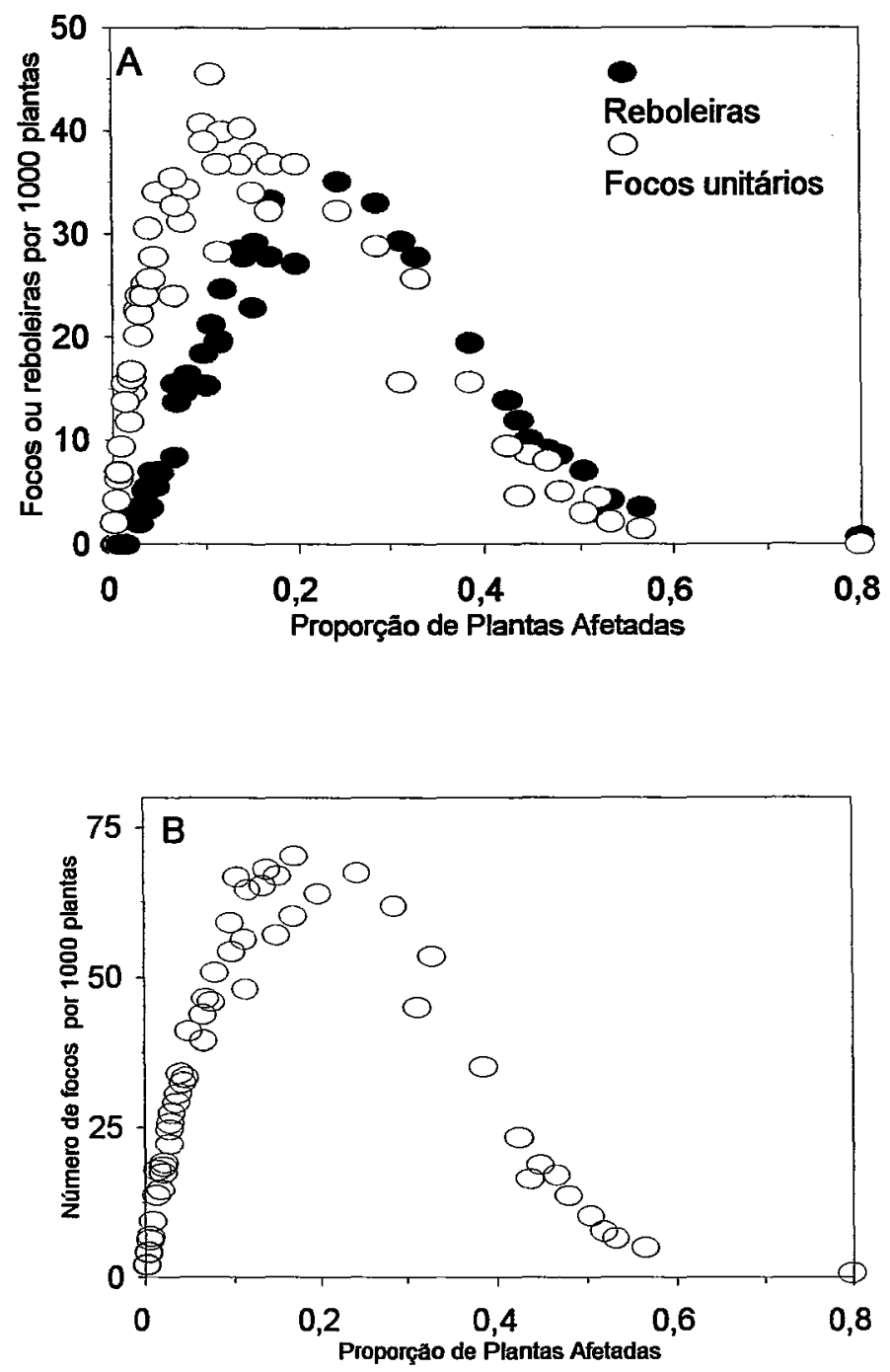

Figura 41 - Número de reboleiras (NRM) e focos unitários (NF1M) - A - e número total de focos por 1000 plantas (NFM) - B - em função da incidência. Dados agrupados dos talhões SJ 01, SJ 67 , SJ 71, SJ 73, SJ 75, SJ 83 e CQH. 


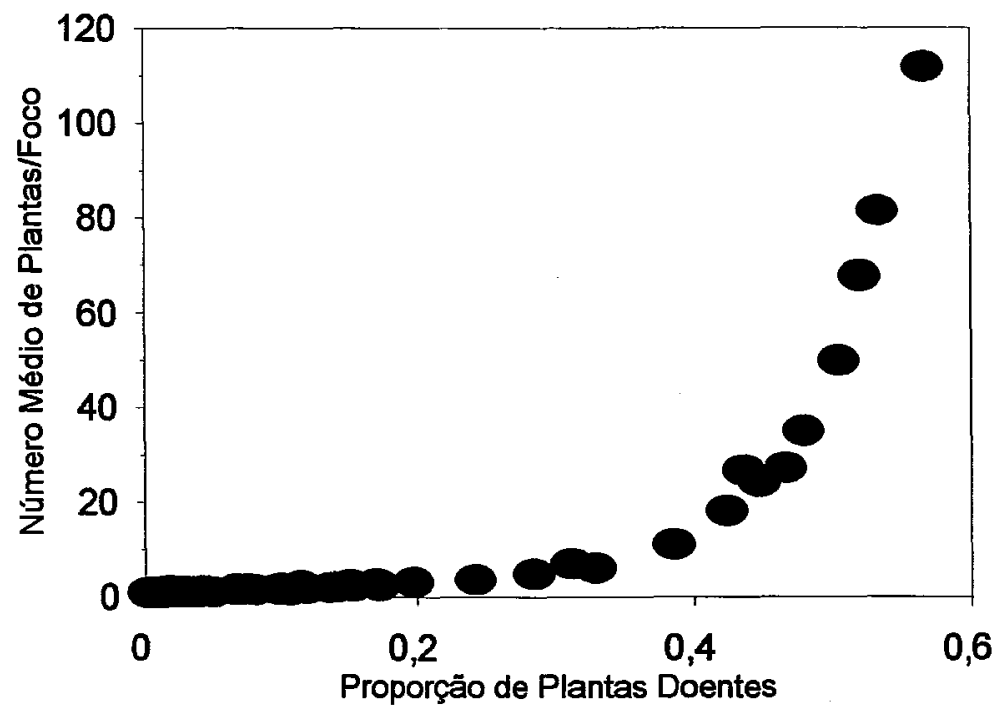

Figura 42 - Tamanho de focos. Relação entre o número médio de plantas por foco e proporção de plantas afetadas. Dados agrupados dos talhões SJ 01, SJ 67, SJ 71, SJ 73, SJ 75, SJ 83 e $\mathrm{CQH}$. 

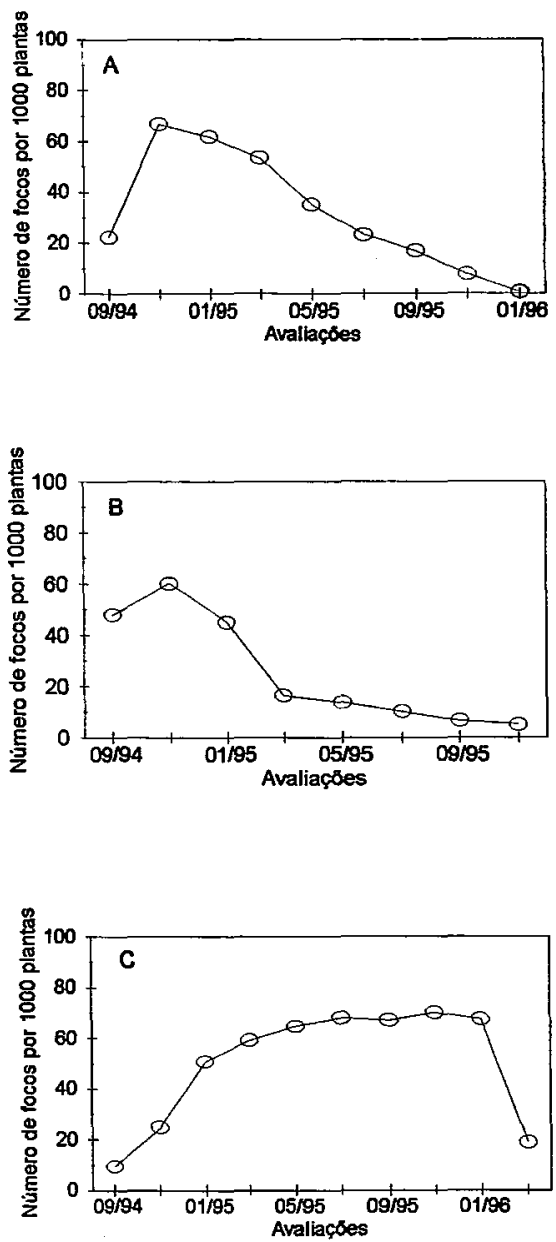

Figura 43 - Evolução do número total de focos por 1000 plantas (NFM) para os talhões SJ 67 (a), SJ 71 (b) e SJ 75 (c) com os respectivos picos de NFM. 


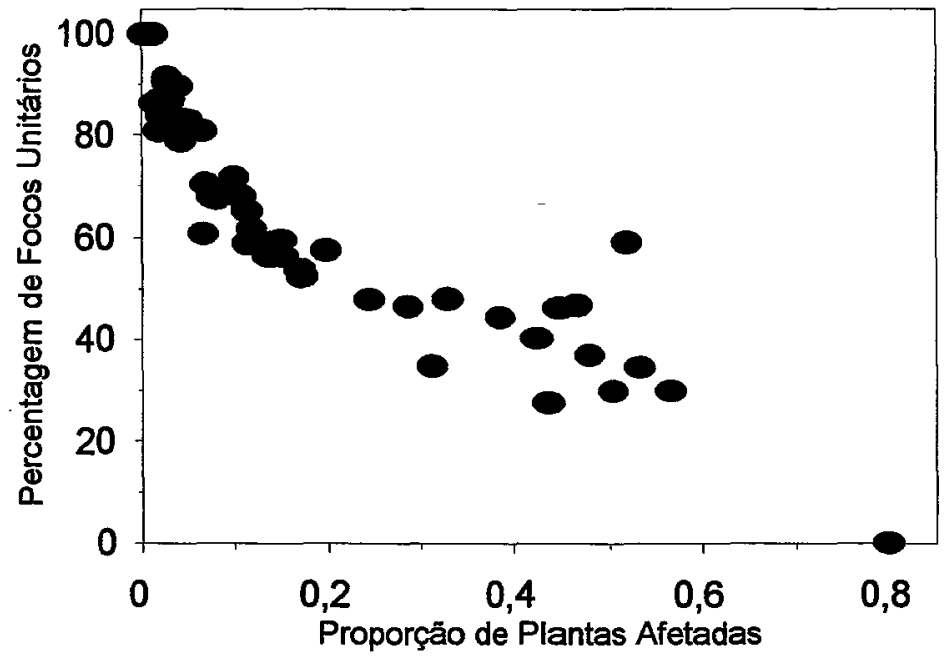

Figura 44 - Relação entre a percentagem de focos unitários e proporção de plantas afetadas. Dados agrupados dos talhões SJ 01, SJ 67, SJ 71 , SJ 73, SJ 75, SJ 83 e CQH. O percentual é em função do número total de focos. 


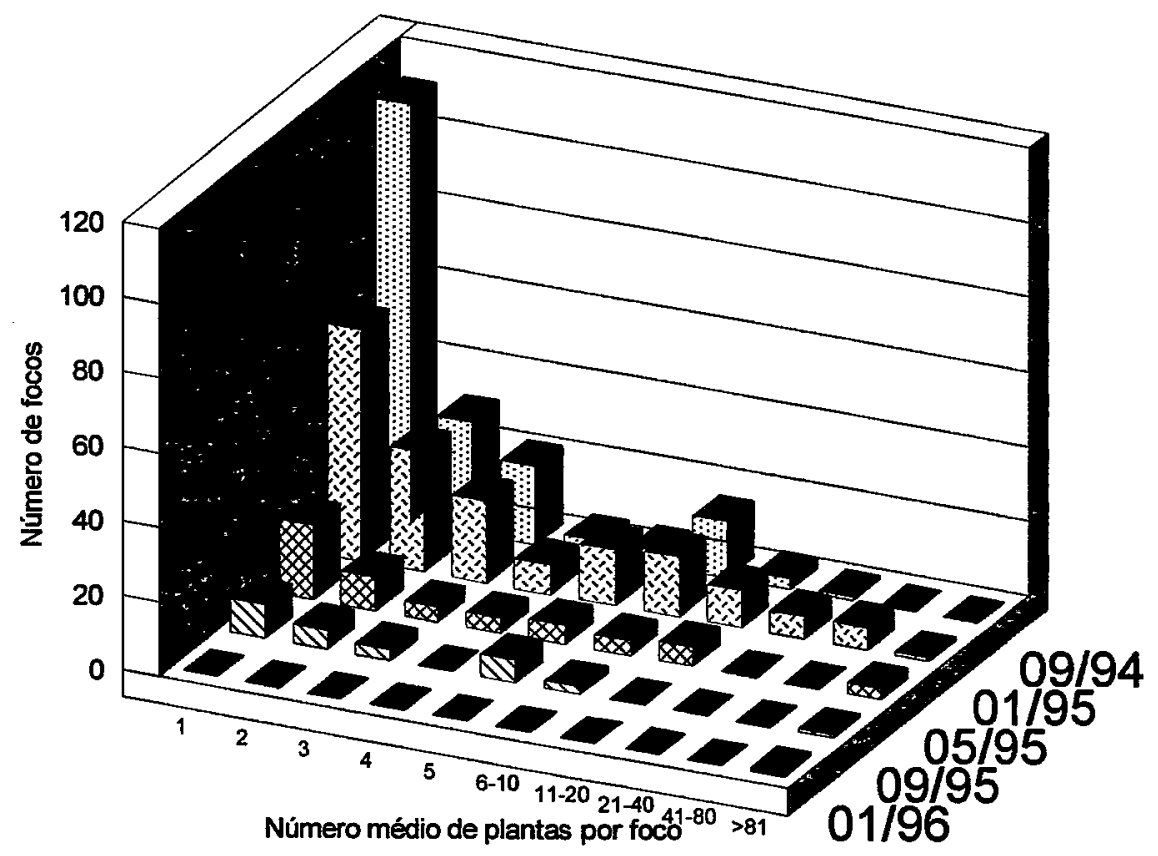

Figura 45 - Distribuição de freqüência do número de focos em função do número médio de plantas por foco para o talhão SJ 71 em cinco avaliações. 


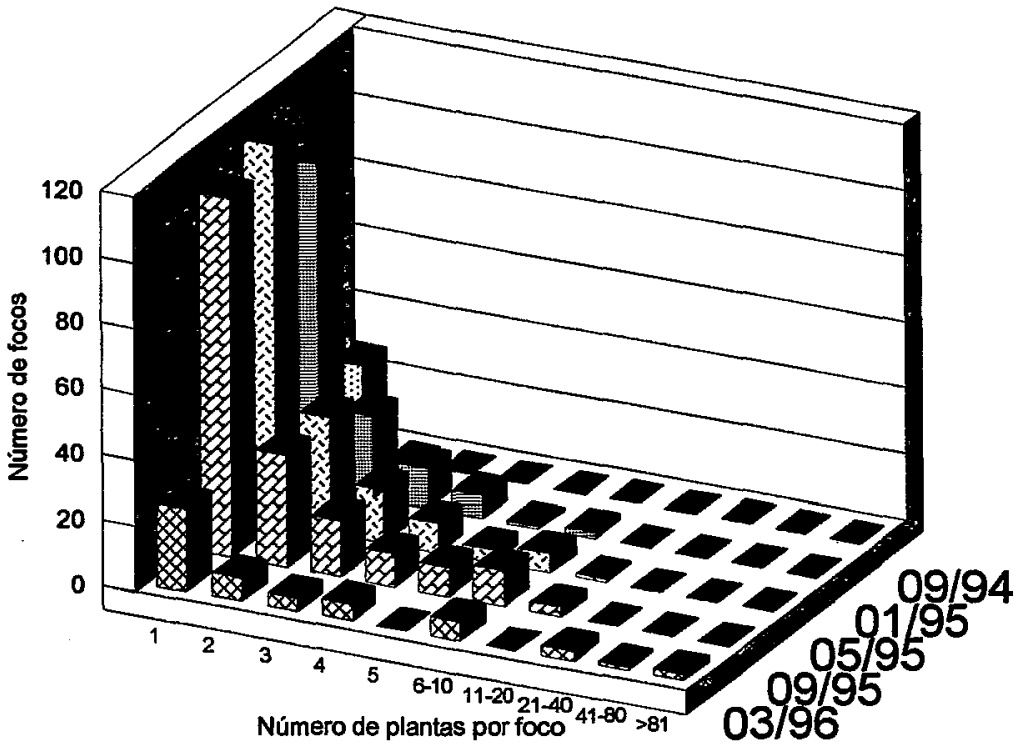

Figura 46 - Distribuição de freqüência do número de focos em função do número médio de plantas por foco para o talhão SJ 75 em cinco avaliações. 


\subsubsection{Tamanho de focos}

Os focos apresentaram tamanhos, na média, inferiores a dez plantas até 0,3 de proporção de doença. A partir daí a tendência de aumento foi exponencial (Figura 42). O mesmo padrão foi observado para tamanho de reboleiras. Em apenas $17 \%$ dos casos os focos médios tiveram tamanho superior a dez plantas. Obviamente, quanto mais situações ocorressem de alta incidência, maior teria sido o número de focos acima daquele tamanho.Os padrões de tamanho de foco de cada área não diferiram do observado para os dados agrupados. $O$ padrão para reboleiras foi similar ao de focos. Corroborando essas observações em relação às médias, as Figuras $45 \mathrm{e}$ 46 apresentam a freqüência de distribuição de tamanho de focos para dois talhões. Para o SJ 71, é observado que a grande maioria dos focos possui menos de 20 plantas, situação que se repetiu para todos os talhōes examinados. Para o SJ 75, assim como para todas as avaliações com baixas incidências dos outros talhões, notou-se uma predominância de focos pequenos, em especial unitários. Apesar disso, mesmo antes da coalescência de focos, aglomerados de mais de 10 plantas doentes já podiam ser observados. 


\section{DISCUSSÃO}

\subsection{Avaliações}

O levantamento de plantas com CVC através de exame visual se mostrou adequado, ou seja, não houve problemas para a identificação dos sintomas da doença. No período de outono/ínverno o comum era não encontrar sintomas foliares, fosse pela queda natural das folhas afetadas, fosse por uma maior quantidade de poeira depositada nas folhas ou por mascaramento de sintomas devido à perda de turgor por déficit hídrico, natural nessa época do ano (ORTOLANI et alii, 1991). Mesmo assim, as detecções não foram interrompidas, embora tenham ocorrido em menor número que em outras épocas. Nesse periodo, a ocorrência de frutos miúdos e já amarelados devido à doença foi bastante útil na avaliação das plantas. DE NEGRI \& GARCIA Jr. (1993) e SUGIMORI et alii (1996) sugerem, inclusive, que os sintomas são mais intensos na época mais seca do ano.

Apenas em duas avaliaçōes, e só no talhão SJ 01 , houve necessidade da utilização de teste serológico para eliminação de dúvidas a respeito de sintomas observados. GOTTWALD et alii (1995) afirmam que, para a deteç̧ão e confirmação de viroses e organismos fastidiosos em plantas perenes, freqüentemente é necessário o uso de testes serológicos ou moleculares. Para a $\mathrm{CVC}^{6}$ foi constatada, por meio dos testes serológicos ELISA e DIBA, que a distribuição da bactéria é muito irregular entre os quadrantes das plantas. Mesmo em plantas bastante afetadas, em apenas $30 \%$ das amostras não-sintomáticas coletadas há deteção do patógeno. Por outro lado, mesmo que o teste de "Polimerase Chain Reaction" já estivesse desenvolvido para detecção da Xylella fastidiosa causadora da CVC (COLETTA FILHO et alii, 1996), seria muito difícil a

\footnotetext{
${ }^{6}$ Francisco Ferraz Laranjeira, PqC I, Centro de Citricultura Sylvio Moreira - IAC, não publicado
} 
sua utilização nesse trabalho, já que a execução é trabalhosa, não muito rápida ${ }^{7}$ e havia cerca de 16.000 plantas a serem avaliadas a cada dois meses.

\subsection{Progresso no tempo}

\subsubsection{Escolha do melhor modelo}

As curvas de progresso da CVC seguiram um padrão denominado sigmóide duplo (BERGAMIN FILHO \& AMORIM, 1996), que também pode ser observado para outros sistemas (HAU et alii, 1993). EISENSMITH et alii (1980), por exemplo, procurando prever o crescimento de folhas, frutos e gemas de cereja (Prunus cerasus $L$. cv. Montmorency), a partir do acúmulo de graus-dia, relataram que o crescimento dos frutos seguia o padrão sigmóide duplo. Da mesma forma, no Brasil, PEREIRA \& SÃO JOSÉ (1988) relataram o mesmo padrão para crescimento de frutos de goiaba. Em fitopatologia, embora esse padrão para curva de progresso de doença não seja comum, alguns casos já foram relatados, embora nem sempre tenham sido analisados de forma conveniente. Nesse contexto, LACKNER \& ALEXANDER (1984) estudaram a incidência e o desenvolvimento de Verticicladiella procera em plantaçōes de pinheiros da Virginia, e, embora a curva de progresso da doença apresentasse duas fases distintas, os autores trabalharam como se estivessem lidando com uma "doença de juros simples", sensu VAN DER PLANK (1963). Como os modelos comuns para a análise de progresso de doenças de plantas não têm flexibilidade para ser ajustados a curvas com variação tão grande da taxa de infecção (AMORIM \& BERGAMIN FILHO, 1991), os dados foram ajustados aos modelos generalizados dos modelos logístico, Gompertz e monomolecular descritos por HAU et alii (1993). Segundo os referidos autores, eles representam a junção de duas equações dos modelos originais.

A escolha do modelo logístico generalizado de 5 parâmetros para representar as epidemias refletiu seu excelente ajuste aos dados (alto $R^{2}$ e ausência de padrões no gráfico de resíduos), mas também a não-distorção das estimativas do parâmetro p1 da equação. Apesar disso, o modelo Gompertz generalizado de 5 parâmetros também apresentou resultados satisfatórios, tornando possível sua utilização para representar epidemias de CVC. Em verdade, a ocorrência de valores distorcidos de

\footnotetext{
${ }^{7}$ Coletta Filho, H.D., em comunicação pessoal, 1996
} 
p1 pode ser solucionada fixando-se o valor de $p 1^{8}$. O modelo logístico não apresentou valores de $R^{2}$ menores que 0,972 , chegando, inclusive, a valores muito altos $(0,996)$. Gompertz generalizado de 5 parâmetros, por sua vez, produziu $R^{2}$ variando de 0,956 a 0,997. De acordo com AMORIM et alii (1993a), valores superiores a 0,97 podem ser considerados excelentes. Também HAU et alii (1993), trabalhando com curvas de progresso do carvão da cana-de-açúcar, usando também como critério os valores de $R^{2}$, concluiram que os modelos generalizados de 5 parâmetros davam melhor ajuste que os de 4 parâmetros. Essa situação deve ser corriqueira, já que equações com mais parâmetros são mais flexíveis e, portanto, mais versáteis.

Os resultados apresentados discordam daqueles obtidos por GOTTWALD et alii (1993). Esses autores, em avaliações anuais, acharam que o progresso da CVC seguia o modelo simples de Gompertz. A diferença de resultados se deve ao intervalo de tempo entre avaliaçōes. Enquanto eles só fizeram levantamentos uma vez ao ano, aqui foram realizadas cerca de seis avaliações anuais, tendo sido possível observar detalhes que aqueles autores não puderam detectar. É possível que, com uma análise de informações em base anual, sejam obtidos resultados similares aos de GOTTWALD et alii (1993). Além da CVC, dentre as doenças causadas por $X$. fastidiosa, apenas para a doença de Pierce da videira já foi determinado o progresso no tempo. Segundo VAN DER PLANK (1963), a doença de Pierce segue um padrão de "doença de juros simples", ou seja, as plantas infectadas não são fonte de inóculo para outras plantas no mesmo ciclo de cultivo. De fato, tal fenômeno já foi demonstrado para a videira (PURCELL \& HOPKINS, 1996), mas não parece ser o caso para a CVC.

A constatação de que um modelo logístico é o que melhor representa os dados obtidos sugere que a CVC é uma doença policíclica, ou por outra, que plantas de laranja afetadas são fonte de inóculo para as sadias. Por outro lado, mesmo fazendo uso de modelos biológicos (sensu MADDEN, 1980), de acordo com PFENDER (1982), devese fazer distinção entre formato de curvas de progresso e a natureza do ciclo da doença. Como o curso de uma epidemia pode ser afetado por níveis de inóculo, suscetibilidade do hospedeiro e ambiente, a simples dedução de que uma doença é mono ou policíclica, a partir da forma das suas curvas de progresso, pode levar a conclusões errôneas. A mesma consideração foi feita por AMORIM et alii (1993a), quando usaram modelos

\footnotetext{
${ }^{6}$ Profa. Dra. Lilian Amorim, Dep. Fitopatologia, ESALQ/USP.
} 
sigmóides duplos, no estudo do carvão da cana-de-açúcar. No caso de curvas em duplo sigmóide, no entanto, a questão fundamental é a existência de fases de progresso muito rápido, contrastando com fases de quase paralização no desenvolvimento da epidemia, $e$ as forças que direcionam esse comportamento.

\subsubsection{Taxas de progresso}

Foi demonstrado que para modelos em sigmóide duplo, as taxas são altamente variáveis, com uma evolução parabólica e valores de mínimo iguais ou menores que zero (Figura 13). Como salientaram HAU et alii (1993), a curva dos valores de $r$ no tempo é quadrática, tendo um discriminante igual ou menor que zero. No caso das epidemias de CVC analisadas, a primeira situação foi a usual. Todos os discriminantes calculados (r mínimos) foram valores muito próximos de zero, sendo considerados como tal. Assim, ficou caracterizada a ocorrência de um ponto de paralização do progresso da doença. $O$ tempo de ocorrência dos valores mínimos da taxa de infecção, segundo previsão do modelo, variou entre cerca de oito meses e pouco mais de onze meses a partir do início das epidemias. Essa lacuna de três meses parece estar mais relacionada à data de aparecimento das primeiras plantas afetadas (SJ 83) ou à data de início das avaliações (CQH) e não a uma variação em função de fatores das áreas estudadas; isso porque a época de ocorrência do $r$ mínimo foi sempre a mesma para todas as áreas, ou seja, outono/inverno. A ocorrência de taxas mínimas sempre entre o outono e o inverno sugere que nessa época os mecanismos de dispersão do patógeno são menos ativos. Assim, é possível que essas estações do ano sejam as menos propicias para atividade de vetores dentro o pomar de plantas cítricas.

Foi observada uma relação inversa significativa entre as taxas de progresso da CVC e o inóculo inicial, ou seja, quanto maior o inóculo inicial menores as taxas médias de progresso da CVC. BERGER (1988), em uma análise sobre o efeito de medidas de controle no progresso de epidemias, e em especial sobre o efeito da sanitização, cita a ocorrência do mesmo fenômeno em outros patossistemas e levanta a questão da universalidade da dependência da taxa de progresso em relação ao inóculo inicial. Embora os resultados obtidos para CVC nas áreas estudadas sejam claros, não se pretendeu, a priori, estudar o fenômeno descrito por BERGER (1988). As áreas não eram similares e natureza, tamanho e localização das fontes de inóculo foram variáveis 
não-controladas. A determinação da ocorrência generalizada desse tipo de fenômeno no patossistema CVC pode ter influência decisiva em relação ao manejo da doença, notadamente no que se refere à produção de mudas sadias. Provavelmente a tolerância quanto à existência de material infectado deva ser zero, levando em conta que incidências baixas podem levar a progressos rápidos.

\subsubsection{Derivadas}

As derivadas dy/dt apresentaram formato característico do modelo utilizado, com dois picos de máxima (BERGAMIN FILHO \& AMORIM, 1996). A existência desses dois picos, mais do que uma relação matemática, refletiu a existência de épocas mais favoráveis ao progresso da doença. Essas épocas foram identificadas como as primaveras e os verões. Considerou-se cada estação do ano como o período compreendido entre os solstícios e os equinócios, muito embora as relações observadas devam estar mais diretamente ligadas às condições ambientais que a períodos de tempo previamente definidos. As condições climáticas poderiam afetar não só o hospedeiro e 0 patógeno, mas também os vetores. Também PALAZZO \& CARVALHO (1992) observaram que o progresso da CVC é mais acentuado entre a primavera e o verão, fato que supuseram estar relacionado a maiores temperatura e precipitação pluviométrica, fatores cruciais para um maior desenvolvimento de brotações. No entanto, não apresentaram uma relação forte entre os fenômenos.

A época de ocorrência de depressões de derivada coincidiram com as épocas em que normalmente não há brotaçōes nos citros e as plantas estão geralmente sujeitas a déficit hídrico (ORTOLANI et alii, 1991). Em contraste, os picos das curvas de derivada, correspondendo às fases de maior progresso da doença, ocorreram no período de 6 meses referente à época "das águas". A relação entre o progresso de doenças e o desenvolvimento das plantas já é bem conhecido (SEEM, 1989) e a ocorrência de progresso com padrão sigmóide duplo, em função do estádio do hospedeiro, também já foi relatado. HUANG \& KOZUB (1990), estudando a murcha de Sclerotinia em girassol no Canadá, relatam que a doença apresentou maior progresso em duas fases. A primeira correspondeu à fase de estabelecimento da cultura e, segundo esses autores, nem sempre é notada. Após isso, e durante a fase vegetativa, o progresso foi praticamente nulo, sendo retomado nas fases de florescimento e desenvolvimento das 
sementes. Os autores sugerem que a germinação de certo tipo de escleródio poderia ser estimulada por exsudatos das plantas durante essas últimas fases. Também a relação clima-doença tem sido extensivamente estudada, existindo pelo menos um relato ligando esporos e época do ano em que o padrão de disponibilidade dos esporos se apresenta em sigmóide duplo. PUSEY (1989) encontrou que ascósporos e conídios de Botryosphaeria em pomares de pêssego são capturados de forma mais intensa em épocas mais úmidas, notadamente quando há muito orvalho ou névoa.

No presente estudo, não se conseguiu relacionar, de modo conspícuo, a derivada das curvas de progresso com as curvas de precipitação pluviométrica, temperatura média ou umidade relativa do ar. Apesar disso, esses fatores, afetando todos os componentes do patossistema, devem exercer influência marcante no progresso da CVC e as diferenças de taxa média entre estações do ano é evidência bastante forte disso. No entanto, esse estudo não teve como objetivo tal tipo de avaliação e, portanto, a metodologia não foi específica. Por outro lado, a julgar pelas evidências apresentadas e pela grande semelhança das curvas de temperatura e precipitação com as curvas de derivada, a relação clima x progresso da CVC é passivel de ser estudada com mais detalhes.

\subsubsection{Assíntotas}

O valor da assíntota máxima, aqui representado por $p 1$, é um dos descritores de epidemias que podem ser obtidos por meio da análise das curvas de progresso de doenças. Essa variável pode ser usada para comparar a influência de diversos fatores nas epidemias e, entre eles, as variedades das espécies vegetais (CAMPBELL \& MADDEN, 1990; KRANZ, 1990; MADDEN \& CAMPBELL, 1990; BERGAMIN FILHO \& AMORIM, 1996). Os valores de $p 1$ estimados pelo modelo logístico de cinco parâmetros e apresentados na Tabela 1 mostram uma grande variação, desde 0,09 até 0,9999 de proporção de plantas afetadas. Desde que os valores de inóculo inicial estimados não diferem muito entre os onze talhōes (Tabela 4) e o padrão de progresso no tempo é o mesmo, parece sensato admitir que essa variação pode ter ocorrido em função de diferenças de reação entre as variedades. Os talhões de Pera (SJ 67 , SJ 71 e SJ 75), por exemplo, foram os que apresentaram maiores valores de $p 1$, contrastando com os obtidos para os talhões em Hamlin e Natal. Em média, as áreas de 
Hamlin obtiveram $p 1=0,1976$, o talhão de Natal (SJ 73) alcançou uma assíntota de $0,1897 \mathrm{e}$ as três áreas de Pera, um $p 1=0,8113$. Embora não existam informações precisas sobre a reação de Hamlin e Natal frente a CVC, a laranja Pera é considerada uma das variedades mais suscetiveis (LARANJEIRA, 1997).

\subsection{Distribuição espacial}

\subsubsection{Análise de sequência ordinárias}

A análise de seqüências ordinárias permite a constatação de agrupamento dentro de linhas de plantio ou em sentido perpendicular a elas. Assim, é possível relacionar (indiretamente) o padrão espacial encontrado a práticas de manejo adotadas nos locais estudados. Nas áreas avaliadas no presente trabalho foram utilizadas duas variações da ASO. Na primeira delas a aleatoriedade do padrão espacial é testada em cada linha de plantio, determinando-se a proporção de linhas com agregação significativa. Na segunda variação, a agregação é testada considerando a área como um todo. As duas aplicações da técnica foram sugeridas por CAMPBELL \& MADDEN (1990), e a escolha depende do interesse do pesquisador ou do número de plantas por linha. Nos casos em que esse número é bem menor que vinte, o segundo tipo de aplicação é o mais recomendado.

Para as áreas onde se optou pelo cálculo de um valor geral, apenas em dois talhões observou-se uma tendência ao agrupamento. Nos demais houve avaliações com índices menores que $-1,64$, mas que se mostraram ocasionais. Além disso, para 0 $C Q N$ e o CQP, devido aos arranquios de árvores doentes que esses talhões sofreram, só foi possivel a realização da análise de seqüências ordinárias (ASO) em duas avaliações e em nenhum caso foi constatada agregação. No CQN, ademais, houve uma leve tendência à regularidade (valores positivos). É possível que esse padrão tenha ocorrido devido a uma quantidade grande de inóculo inicial (mudas contaminadas), distribuído por toda a área, ou em função de uma disseminação muito rápida. Mesmo tendo ocorrido poda e arranquio nessas áreas, após um ano, essas práticas não conseguiram alterar a distribuição espacial da CVC.

Naqueles talhões avaliados em termos de percentagem de linhas com agregação, esse valor nunca ultrapassou $55 \%$ e, em média, ficou em $16 \%$. Embora não 
haja critérios para decidir se determinada percentagem de linhas agregadas é alta ou baixa, partiu-se do pressuposto de que, se a tendência ao agrupamento fosse forte, pelo menos $50 \%$ das linhas deveriam estar com agregação, na maioria das avaliações, o que não conteceu. Dessa forma, não se considerou que $X$. fastidiosa tenha uma disseminação eficiente ao longo das linhas. Considerando que é válida a suposição de VAN DER PLANK (1946) apud MADDEN et alii (1982) de que aglomerações de plantas doentes indicam que o patógeno está sendo disseminado de planta a planta, e tendo em vista os resultados obtidos, não há como afirmar que a transmissão da doença se dê preferencialmente ao longo das linhas de plantio. Se assim fosse, o percentual médio de linhas com plantas doentes agregadas seria bem maior. Dessa forma, a contribuição que passagens de máquina possam ter dado à disseminação da bactéria nas áreas estudadas não deve ser significativa. Em outras palavras, essa é uma evidência indireta de que aplicações de defensivos e adubos, e ainda roçagens e gradagens, não devem influenciar a disseminação do patógeno ou a manifestação dos sintomas da CVC. GOTTWALD et alii (1993), estudando a distribuição espacial da CVC em um pomar de São Paulo, e aplicando o mesmo tipo de análise, chegaram à mesma conclusão. $A$ disseminação não se dava preferencialmente entre plantas de mesma linha, sendo inconsistente com práticas culturais. Segundo eles, a proporção de linhas com agregação significativa foi maior entre linhas (maior espaçamento) que dentro das linhas de plantio (menor espaçamento) como seria esperado. Em outros patossistemas envolvendo $X$. fastidiosa, não há informaçōes sobre o uso desse tipo de análise ou mesmo de influência dos tratos culturais na disseminação da bactéria. Em outros patossistemas citrícolas com presença de vetor, a caracterização do agrupamento dentro de linhas de plantio não tem sido feita com o objetivo de avaliar o papel de atividades humanas na disseminação do patógeno; visa-se, mais, a simples determinação das características do agrupamento, que nem sempre é significativo (GOTTWALD et alii, 1991a; GOTTWALD et alii, 1991b; GOTTWALD et alii, 1996).

Segundo HEADY \& NAULT (1985), a resposta de escape de cigarrinhas, ou seja, o vôo induzido por perturbações mecânicas no seu ambiente, pode variar conforme o gênero e até espécie. Assim, é possível que as cigarrinhas vetoras de $X$. fastidiosa em citros não tenham uma boa resposta de escape ou, nesse movimento, não tenham preferência pela planta mais próxima. Dessa maneira, as passagens de máquina 
pelos talhões não induziriam os insetos ao vôo ou, se induzidos, os vetores não tenderiam a pousar, necessariamente, nas plantas mais próximas (dentro das linhas de plantio, em função do menor espaçamento).

\subsubsection{Vizinho mais próximo e distância entre plantas afetadas}

A aplicação do teste de Clark \& Evans (CE) modificado (RIPLEY, 1979) no diagnóstico da distribuição espacial da CVC, permitiu avaliar a agregação das plantas doentes como um todo em uma dada área, não levando em consideração a direção do agrupamento.

A constatação de aleatoriedade para incidências menores que $3 \%$ permite ver uma situação em que, mesmo havendo presença de fontes de inóculo importantes, essas fontes não foram as únicas forças existentes de direcionamento da disseminação. Essa situação leva a duas possibilidades, que podem ter ocorrido de modo excludente, mas que, mais provavelmente, aconteceram em simultaneidade. A primeira, a de que uma fração da população dos vetores se moveu para áreas mais distantes das fontes principais de inóculo, estabelecendo um padrão aleatório de pouso e, em conseqüência, de transmissão da doença. A segunda possibilidade invoca a presença de mudas contaminadas em pré-plantio, ou seja, ainda no viveiro. Essa situação é muito comum na região norte-noroeste do Estado de São Paulo. $O$ aumento progressivo na agregação das plantas doentes foi captado por uma diminuição nos valores do índice $C E$, refletindo uma maior influência das plantas doentes no estado patológico das suas vizinhas mais próximas. Essa influência, como foi mostrada na ASO, não foi exercida, necessariamente, nas plantas imediatamente vizinhas. Mesmo assim, é evidência de transmissão planta a planta dentro de um mesmo pomar, fato que não ocorre, por exemplo, no patossistema da doença de Pierce da videira (PURCELL \& HOPKINS, 1996). A tendência de aumento nos índices $C E$, em especial após os $15 \%$ de incidência, mostrou uma mudança no status espacial das plantas doentes que passaram então a se distribuir de maneira regular nas áreas avaliadas, ou pelo menos onde tal fato foi mais característico, os talhões SJ 67, SJ 71 e SJ 75. Nesses casos, é possível que o padrão de regularidade tenha assumido relevância em função de coalescência de grupos de plantas doentes. 
Essa tendência à regularidade pode ser admitida como confiável, tendo-se em conta que RIPLEY (1979) considera esse teste muito poderoso para apontar tal situação. Regularidade na distribuição de patógenos ou plantas doentes não é situação comum (CAMPBELL \& MADDEN, 1990). Mesmo assim, o valor mínimo de incidência no qual foi constatada homogeneidade foi de $24 \%$ (talhäo SJ 75 ), o que sugere que o potencial de disseminação da doença é alto. Isto é, mesmo em incidências não muito altas, em todo o talhão já eram encontradas plantas doentes. Os talhões CQH e SJ 83 e as sub-áreas SJ 01-2, SJ 01-3 e SJ 01-4 não apresentaram agregação de plantas doentes, segundo o índice $C E$, entrando em acordo com os resultados obtidos com a ASO.

O estudo de distância entre plantas pretende, mais que determinar a condição espacial de uma doença, apontar a separação média entre entidades afetadas. Essa determinação pode ser de interesse para trabalhos de levantamento, como apresentado por MARCUS et alii (1984). Quando as distâncias mais freqüentes foram calculadas (correspondendo à avaliação relacionada à primeira assíntota da curva de progresso prevista pelo modelo logístico de cinco parâmetros), obteve-se que, de maneira independente da incidência, a distância mais freqüente entre plantas doentes situou-se sempre na faixa de 1 a 8 plantas ( $3 \mathrm{~m}$ a $28,3 \mathrm{~m}$, dependendo do espaçamento de cada área). Esse pequeno raio pode estar associado a uma tendência dos vetores e de sua progênie em permanecerem agregados, como é comum para muitos insetos (TAYLOR, 1984; BUNTIN, 1988). GOTTWALD et alii (1993), utilizando outro tipo de análise espacial, também chegaram a conclusão semelhante para talhão com CVC na mesma região do presente estudo. Para a Tristeza dos citros, doença de etiologia viral e cujo agente é transmitido por afídeos, MARCUS et alii (1984) encontraram a distância mais freqüente entre plantas afetadas em tomo 14 metros.

\subsubsection{Aplicação da lei de Taylor modificada (LTM)}

A aplicação da LTM teve como objetivos a caracterização espacial das áreas passíveis de serem estudadas e a obtenção de parâmetros de ponderação da variável independente na análise de progresso no tempo. 
Da forma como apresentado por TAYLOR (1961) e HUGHES \& MADDEN (1992), o parâmetro $b$, obtido pela aplicação da LTM, pode ser considerado um índice de agregação. Valores de $b$ estatisticamente superiores a 1 indicam agregação, enquanto valores não diferentes de 1 denotam aleatoriedade. $O$ valor de $b$ obtido para a regressão conjunta de todos os talhões $(b=1,13)$ denota agregação, indicando que plantas afetadas pela CVC tendem a se localizar próximas a outras também doentes, o que concorda com a tendência apontada pela análise de vizinho mais próximo (índice $C E$ ). $O$ valor de $A(A=3,13)$ reforça essa conclusão, já que, segundo MADDEN \& HUGHES (1995), só há agrupamento quando os valores de b e A são superiores a 1. Assim, de maneira geral, fica caracterizada aquela tendência para as plantas afetadas por CVC. Por outro lado, o valor de $b$ não pode ser considerado alto (MADDEN \& HUGHES, 1995), indicando que a agregação, embora existente, não foi, de uma maneira geral, forte. Tal fato se repetiu para a análise dos talhões individuais.

Os resultados da aplicação da LTM (quando considerados os talhões individualmente) refletiram a situação da doença como um todo, ao longo das avaliações. Assim, para o talhão SJ 71 , o valor de $b=0,98$ (estatisticamente não diferente de 1) sugere que as plantas doentes, nesse caso, se apresentaram distribuidas aleatoriamente ou tendendo para a regularidade. No entanto, de acordo com MADDEN \& HUGHES (1995), valores de $b=1$ indicariam aleatoriedade apenas quando $A=1$. Para $A>1$ e $b=1$, a relação variância observada/variância prevista seria sempre maior que 1 (denotando agregação). Essa situação ocorreu nos três talhões cujos valores de $b$ não foram estatisticamente superiores a 1 (SJ 71; SJ 67 e SJ 73). Dessa forma, em nenhum caso o padrão espacial das plantas afetadas pôde ser considerado aleatório, mesmo com os valores de $b$ obtidos. Já para os talhões SJ $01, C Q H$ e SJ 75 a nãoaleatoriedade fica mais clara ainda, pois o $b$ foi estatisticamente superior $a 1$, indicando agregação das plantas doentes. $O$ agrupamento de plantas doentes pode assumir dois significados distintos (VAN DER PLANK, 1963). No primeiro caso, a aglomeração ocorre motivada por fatores locais (tipo de solo, microclima, etc.) envolvidos numa maior favorabilidade à doença. Na segunda situação, o local de maior densidade de plantas doentes estaria relacionado à presença de fontes de inóculo. Esse parece ter sido o caso, considerando os resultados obtidos pela análise de áreas isópatas. 
A lei de Taylor fornece parâmetros que seriam atributos típicos de cada entidade biológica (TAYLOR, 1961; 1984). Entretanto, não fornece informação a respeito da dinâmica da epidemia, não guarda detalhes a respeito das características espaciais de cada ponto dos talhões, mas resume o modo como a epidemia se comportou espacialmente. Apesar das limitações, o uso da LTM é essencial, pelo menos para o estudo de epidemias cuja incidência é o dado mais importante. Nesse estudo, o valor do parâmetro $\boldsymbol{b}$ foi usado para ponderar a variável dependente na regressão não-linear de ajuste do progresso no tempo, de acordo com as argumentaçōes de MADDEN \& HUGHES (1995).

\subsection{4. Índice de dispersão (I $\beta)$}

Como, na grande maioria dos casos, o valor calculado de $\mid \beta$ foi estatisticamente superior a 1 ao nivel de $5 \%$ de significância pelo teste de $\chi^{2}$, concluiu-se que plantas afetadas por CVC tendem a assumir um padrão agregado, conclusão idêntica à obtida pela aplicação da lei de Taylor.

Para todos os talhões o $\mid \beta$ apresentou resultados indicativos de agregação (índice > 1), com exceção do talhão $\mathrm{CQH}$. Nesse caso, apenas o valor de $\mid \beta$ da última avaliação foi estatisticamente superior a 1. A despeito disso, se o $b$ for um indicativo de tendência de distribuição espacial (e de fato o é, já que indica inclinação da reta de regressão), a LTM apenas sugeriu a tendência, enquanto o I $\beta$ apresentou os detalhes de cada avaliação. Em quatro talhões. (SJ 67, SJ 75 , SJ 01 e CQH) os valores de $1 \beta$ tenderam a aumentar com o tempo. No SJ 71 a tendência foi contrária, isto é, os valores de I $\beta$ diminuíram com o tempo e, para o SJ 73, houve variação sazonal. Aparentemente, nesse talhão, os valores de $1 \beta$ tenderam a crescer na primavera/verão e a diminuir no outono/inverno. Com exceção do talhão SJ 73 , em nenhum outro caso foi possivel encontrar padrōes de $\mid \beta$ que pudessem ser relacionados com condições especificas como épocas do ano. Mesmo para o SJ 73, esse fato pode ter sido apenas uma coincidência.

Dessa maneira, o $\beta$ tem uma performance um pouco melhor que a LTM, uma vez que consegue identificar detalhes que escapam a essa técnica. Os resultados obtidos (tanto da LTM quanto do I $\beta$ ) sugerem que, em geral, sob baixas incidências, o 
padrão espacial de plantas com CVC é aleatório, ocorrendo uma posterior agregação. Aparentemente essa agregação, quando distribuída em todo o talhão, leva a situação de regularidade, em condições de alta incidência. Essa mesma constatação pôde ser feita com a aplicação da análise de vizinho mais próximo.

Não existem casos da aplicação dessas técnicas na análise espacial de outras áreas com CVC, assim como para outras doenças causadas por $X$. fastidiosa.

\subsubsection{Determinação de áreas isópatas}

Para essa análise não há determinação de índices ou informações puramente matemáticas. Pretende-se visualizar a forma como a doença se manifestou espacialmente em cada área. A presença de áreas isópatas concêntricas e internas nos talhões SJ 01 e SJ 73 revela uma situação que não ocorreu com freqüência nesse estudo. No SJ 01 , o mais discreto desses focos, localizado no setor noroeste, representa uma aglomeração de plantas doentes que, aparentemente, não teve origem por contaminações a partir de fontes externas. Como as avaliações não foram feitas em todo o talhão, aquele setor é a interface entre a área estudada e mais $\mathbf{2 0}$ linhas de plantio. Assim, essa Al está localizada bem no meio do talhão. Dessa maneira, é muito provável que as infecções detectadas nesse local tenham se originado a partir de mudas contaminadas. Uma outra possibilidade, dentro daquelas apresentadas por VAN DER PLANK (1963), é admitir que esse foco tenha se desenvolvido por estarem as plantas localizadas numa área mais favorável ao desenvolvimento da doença. Entretanto, não foi observado nenhum fator que pudesse sustentar essa hipótese. A outra situação do SJ 01 apresenta uma Al na borda do talhão, no setor que faz divisa com um pasto. Nesse caso, na ausência de informação sobre a ecologia dos possíveis vetores, não é possivel determinar com precisão qual ou quais são as fontes de inóculo. Tanto podem ser mudas de laranja contaminadas como as gramíneas do pasto. Em outros patossistemas, monocotiledôneas já foram determinadas como hospedeiros de Xylella (WEAVER et alii, 1980; PURCELL \& FRAZIER, 1985) e, para a CVC, HARAKAVA et alii (1994) encontraram que Cyperus sp., em pomares cítricos, apresentavam a bactéria em seus tecidos. Por outro lado, a real importância de plantas daninhas e/ou pastos na disseminação da bactéria ainda não foi determinada; todas as afirmaçōes, até o momento, são apenas especulação. Para 0 talhão $S J$, 73 , é possível que as áreas 
isópatas concêntricas tenham se originado a partir de infecções precoces, ocorridas na época do plantio, e que essas primeiras plantas estejam agindo como fonte da bactéria. Apesar disso, não se deve desprezar a influência do SJ 75 no fornecimento de inóculo para o SJ 73. De fato, nota-se que as áreas vizinhas ao SJ 75 estão mais afetadas que aquelas mais distantes. Como o setor oeste do SJ 73 é margeado por plantação de tangerina Ponkan, é natural que a força dessa possível fonte de inóculo seja menor. Por outro lado, é curioso o fato do setor norte possuir, em média, menos plantas afetadas, já que margeado por pomar afetado de laranja Natal. Como esse pomar não foi avaliado, ficou impossivel saber qual a incidência e, assim, determinar sua força relativa. Entretanto, observou-se que as plantas mais afetadas se localizavam distantes do SJ 73.

Talhões vizinhos servindo como fonte de inóculo são relativamente comuns na fitoepidemiologia. Para patossistemas envolvendo $X$. fastidiosa, o mais usual é a presença de gradientes de doença, iniciando-se a partir de outros plantios ou de locais com vegetação nativa. Especificamente para a doença de Pierce da videira, PURCELL (1974) demonstrou que áreas localizadas próximas à vegetação natural apresentavam maior incidência. A doença, quando se manifestava, formava um gradiente de plantas afetadas, desde a vegetação até cerca de 150 metros de distância. PURCELL \& FRAZIER (1985), estudando os hábitats dos vetores da bactéria na Califórnia, comprovaram que plantaçōes de alfafa (também uma hospedeira da bactéria) eram excelentes fontes de inóculo para a videira, se localizadas na sua vizinhança. Para os talhōes SJ 67 , SJ 71, SJ 75 e CQH fica evidente que, a despeito de existirem outras fontes de inóculo, a força que guiou o desenvolvimento das epidemias foi a presença de pomares contaminados na vizinhança. Para o $\mathrm{CQH}$, a manifestação dessa tendência só ficou clara na última avaliação. Apesar de terem sido identificadas três áreas com maior incidência, as localizadas no setores norte e oeste devem ser oriundas de infecçōes secundárias. A área localizada no setor sudeste, a maior delas, tem como fonte de inóculo mais provável o talhão CQN, seu vizinho, que, já na primeira avaliação, apresentou cerca de $30 \%$ de incidência da doença. Para os pomares SJ 67 , SJ 71 e SJ 75 , deve-se considerar o histórico da área, ilustrado na Figura 47. Esses talhōes ocupam hoje área anteriormente mantida com laranja doce de mais de 15 anos de idade. Em 1991 foi iniciado um processo de renovação, quando o talhăo do meio (hoje SJ 71) foi arrancado e um novo pomar foi plantado. Os administradores da fazenda não souberam informar se esses antigos pomares continham plantas afetadas. Porém, considerando o 
padrão das Al encontrado para o talhão SJ 71 (incidências maiores nas bordas), ou havia plantas, nos pomares antigos, que pudessem servir como fonte de inóculo, ou os vetores adquiriram a bactéria em mudas previamente contaminadas desse plantio novo, mas se mantinham em circulação entre esse e os velhos. Sucessivamente, em 1992 e 1993 foram arrancados os pomares restantes e plantados o SJ 67 e o SJ 75, respectivamente. Assim, pode-se observar que as áreas nesses dois talhões com maiores incidências são aquelas vizinhas do $S J$ 71, respectivamente seus setores sul e norte. A partir dessas áreas iniciais, houve a disseminação para o resto do talhão. Essa parece ser uma situação comum para a escaldadura das folhas da ameixeira, já que para essa cultura é recomendação evitar plantios novos proximos a áreas afetadas (ANDRADE, 1995). 

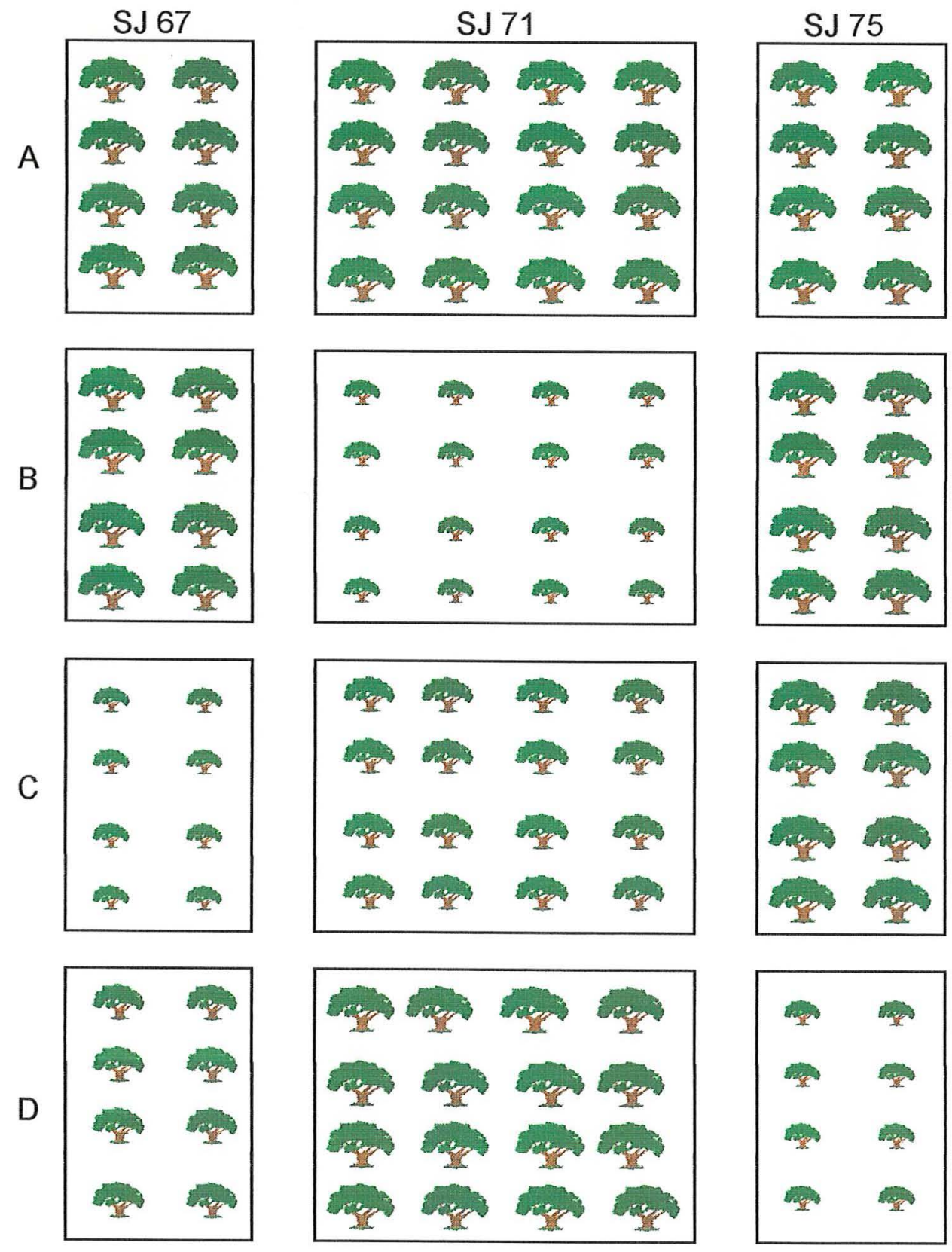

Figura 47 - Representação do histórico dos talhões SJ 67, J 71 e SJ 75. A: situação original, com pomares velhos nas três áreas. B: replantio do SJ 71 após arranquio do pomar inicial (1991). C: replantio do SJ 67 após arranquio do pomar inicial (1992). D: replantio do SJ 75 após arranquio do pomar inicial (1993). Notar diferença de crescimento entre as três áreas, representado por tamanhos diferentes de figuras de árvores. 
Nos talhões CQN e CQP não pôde ser observada nenhuma influência externa na manifestação da doença. O padrão de Al encontrado sugere que as fontes de inóculo são intemas. Como nesses talhões houve arranquio de plantas, devido à grande severidade da doença, e no CQN essas plantas eram muito jovens (pouco mais de um ano de idade), é muito provável que mudas contaminadas em pré-plantio tenham sido introduzidas nessas áreas. Uma evidência indireta desse fato é a observação de que um pomar plantado próximo a pomares mais velhos, já afetados pela CVC, mas cujas mudas foram produzidas em telado, só apresentou plantas sintomáticas após dois anos do plantio e, mesmo assim, os sintomas eram pouco intensos ${ }^{9}$.

Para o talhão SJ 83, apesar de não ter sido possivel a determinação de Al, foi observada uma concentração de plantas afetadas no setor do talhão que bordeja um riacho com mata ciliar. Entre as espécies vegetais que crescem nessa área é provável que existam plantas hospedeiras dos vetores e da bactéria servindo como fonte de inóculo para o pomar. No caso da doença de Pierce, essa é uma situação comum (PURCELL, 1974; PURCELL \& FRAZIER, 1985). Foram feitos testes serológicos em algumas plantas desse bosque (lírio do brejo, capim massambará, braquiária), mas os resultados foram negativos para $X$. fastidiosa. Diante da diversidade de plantas que lá ocorrem, essa informação deve ser vista de forma bastante cautelosa e considerada preliminar. De qualquer maneira, em vista dos resultados obtidos para patossistemas semelhantes, é bastante provável que a maior concentração de plantas doentes próximas à mata não seja um acaso.

A direção dos ventos prevalecentes não pôde ser correlacionada com a direção principal de disseminação, deduzida a partir dos padrões de Al para cada talhão (Tabela 11). De acordo com os dados obtidos junto ao aeroporto de Bebedouro, naquela parte do estado o vento sul tem predominância, havendo ocorrências freqüentes de rajadas no sentido noroeste. Dessa forma, se os ventos tivessem uma participação fundamental na dispersão dos vetores da bactéria, a direção esperada de disseminação seria Sul/Norte ou Noroeste/Sudeste. A primeira direção só foi observada para o talhão SJ 67. Como há explicação melhor para a ocorrência dos padrão de Al relatado (presença de pomar contaminado na vizinhança) e, supondo que a distribuição espacial dos vetores seja similar à distribuição das plantas doentes, é difícil sustentar a

\footnotetext{
${ }^{9}$ Dr. Gerd Walter Müller, Consultor em fitovirologia, Centro de Citricultura Sylvio Moreira-IAC/RHAE, em comunicação pessoal, 1995.
} 
participação do vento na dispersão desses vetores, pelo menos em curtas distâncias. Apesar disso, e como havia fontes de inóculo fortes próximas aos talhões, qualquer influência eólica pode ter sido mascarada. É possivel que, em outras circunstâncias, a influência dos ventos prevalecentes ou as rajadas mais freqüentes sejam detectadas. Para tanto, o monitoramento da velocidade e direção dos ventos nos talhōes seria fundamental. LARSEN \& WHALON (1988), por exemplo, trabalhando com a cigarrinha envolvida com a doença " $X$ " da cereja, mostraram que a dispersão desse inseto foi altamente influenciada pela direção média dos ventos.

Com exceção do presente estudo, a análise de áreas isópatas näo fez parte de nenhum trabalho com doenças causadas por $X$. fastidiosa e, assim, não há como fazer comparaçōes de resultados. Por outro lado, o uso dessa análise na fitopatologia, apesar de não ser amplo, tem encontrado espaço na avaliação de patossistemas tão distintos quanto a verrugose dos citros, causada por Elsinöe fawcettii (GOTTWALD, 1995), quanto a mancha foliar no amendoim, causada por Cercosporidium personatum (ALDERMAN et alii, 1989).

\subsubsection{Análise de dinâmica e estrutura de focos (ADEF)}

O padrão de número de focos unitários (aqueles formados por uma única planta doente) - NF1M e número de reboleiras - NRM - foi semelhante, mas a inclinação inicial da curva de NF1M, sendo muito mais acentuada que a de NRM, indica que, em geral, o início das epidemias se dá através de plantas isoladas, o que concorda com os resultados de aleatoriedade obtidos pelas técnicas anteriores para o começo das epidemias. Além disso, como nessa fase ainda não se pode detectar coalescência de focos, o aumento de NRM sugere que aquelas plantas isoladas estão servindo como fonte de inóculo para as sadias. Contrapondo esse raciocínio com os resultados obtidos na análise de áreas isópatas, pode-se perceber a existência de dois mecanismos de disseminação da bactéria. $O$ primeiro, associado a fontes de inóculo compostas por plantas cítricas doentes de pomar vizinho e o segundo, ligado a uma disseminação intracultivo. Uma outra evidência da transmissão planta a planta é a relação inversa entre percentagem de focos unitários e proporção de plantas doentes. Isso ocorreu mesmo para incidências inferiores a $20 \%$, quando ainda não havia coalescência de focos. A transmissão de $X$. fastidiosa de planta a planta dentro da cultura não é comum. 
PURCELL \& FRAZIER (1985), trabalhando com videira na Califómia, e MIZELL \& FRENCH (1987), trabalhando com pessegueiro na Geórgia, sugerem que as culturas sejam apenas hospedeiros ocasionais dos vetores, não havendo ciclos da doença dentro das plantações. Por outro lado, sendo espécies decíduas, as infecções oriundas de ciclos secundários podem não se tomar viáveis de um ano para o outro (PURCELL, 1994). Esse não parece ser o caso da CVC.

O pico de número total de focos por 1000 plantas (NFM) se deu entre 0,2 e 0,3 de proporção de doença e a coalescência de focos foi constatada a partir da ocorrência do pico de NFM. Esses dois fenômenos, claramente associados, ocorreram conforme previsto por NELSON (1996). De acordo com esse autor, o máximo teórico de NFM se dá em torno de 0,25 de proporção de doença, para talhões equiláteros, quando só há focos unitários na área em questão. A coalescência de focos foi indicada não só pela redução em seu número após o pico, mas também pelo aumento de tamanho médio nessas estruturas (focos). De maneira similar, foi freqüente a observação de que índices Clark \& Evans (CE), indicativos de regularidade, começaram a ocorrer em incidências semelhantes às dos picos de NFM. Sendo assim, é possivel que apenas o estudo de dinâmica e estrutura de focos possa ser usado como indicação de regularidade para componentes de sistemas biológicos. Nesse caso, ampliação de estudos nessa área é requerida, não só para agropatossistemas, mas para qualquer um que seja examinado dentro da abrangência da ecologia.

\subsection{Visão geral do patossistema e síntese}

\subsubsection{Variáveis climatológicas, crescimento do hospedeiro e adubações}

Os dados obtidos na Estação Experimental de Citricultura de Bebedouro para o período experimental estiveram coerentes com os considerados típicos por ORTOLANI et alii (1991) e estão apresentados na Figura 48. Foram observados picos de precipitação pluviométrica e temperatura no verão. As precipitações e temperaturas mais baixas foram encontradas no outono/inverno e sua diminuição iniciou-se em abril de 1995. Um retorno a temperaturas mais elevadas e também a maiores precipitações deuse por volta de setembro de 1995. A umidade relativa do ar seguiu o mesmo padrão dessas variáveis. 


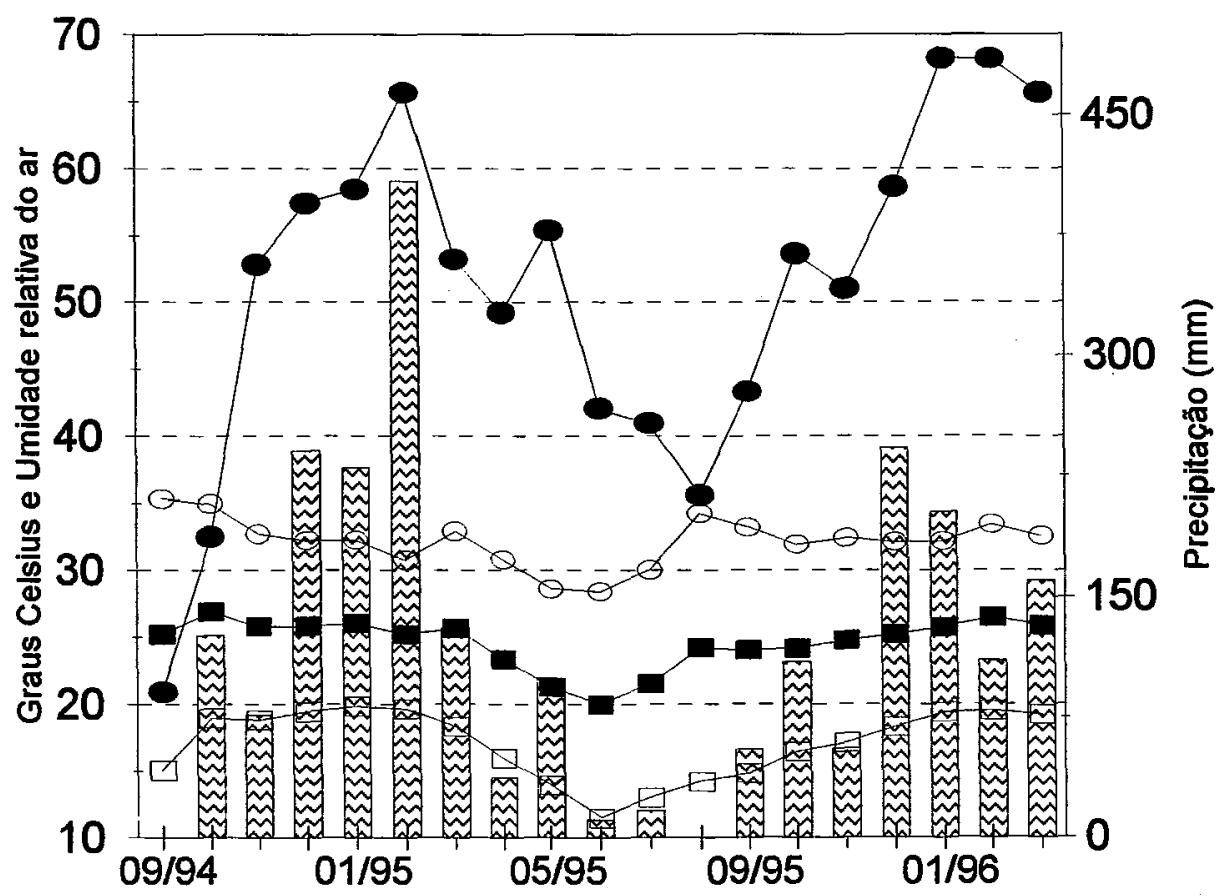

Figura 48 - Dados climáticos mensais obtidos na Estação Experimental de Citricultura de Bebedouro para o período do estudo, em que: precipitação pluviométrica em milímetros de chuva (barras verticais); umidade relativa do ar média (círculos pretos); temperatura máxima média em graus Celsius (círculos brancos); temperatura média em graus Celsius (quadrados pretos) e temperatura mínima média em graus Celsius (quadrados brancos). 
Observou-se ainda que os maiores progressos da doença ocorreram quando havia abundância de água e temperaturas elevadas, coincidindo também com o periodo em que normalmente são feitas as adubações (primavera e verão). Em conseqüência desses fatores, uma profusão de brotos novos é produzida nas plantas citricas. Apesar de não ter sido feita a quantificação do crescimento do hospedeiro, como enfatizado por SEEM (1989), a situação descrita é largamente conhecida para as condições do planalto paulista (TUBELIS, 1995). Em especial na região norte do Estado, a alternância entre estaçōes secas e úmidas é pronunciada (TUBELIS, 1995). De acordo com esse autor, o período compreendido entre setembro e março é aquele que exibe brotações mais intensas e rápido crescimento de ramos. A partir de abril, as temperaturas caem rapidamente, assim como as precipitaçōes e, até o final de julho advém o periodo de mais baixas temperaturas, consideradas marginais para os citros. Em agosto ocorrem apenas chuvas ocasionais, insuficientes para as necessidades das plantas cítricas. Segundo ORTOLANI et alii (1991), é entre abril e agosto que se observa o déficit hídrico naquela região.

Embora tenha-se algum conhecimento sobre a influência do clima no hospedeiro, pouco se sabe sobre a influência das relações entre clima e planta cítrica no comportamento dos possiveis vetores no patossistema da $\mathrm{CVC}^{10}$. A relação entre estresse hídrico e aspectos populacionais de insetos tem sido objeto de estudos e, segundo HOLTZER et alii (1988), as respostas variam conforme o grupo de inseto estudado. Ainda de acordo com os mesmos autores, esse tipo de estresse deve afetar mais os insetos sugadores, como afídeos e cigarrinhas. Em alfalfa, também hospedeira de Xylella fastidiosa (GOHEEN et alii, 1973), HOFFMAN \& HOGG (1991), trabalhando com a cigarrinha da batata, Empoasca fabae, mostraram que, quanto maior o déficit hídrico, menor a taxa reprodutiva do inseto. Demonstraram ainda o efeito deletério da diminuição do suprimento de água na fecundidade dos adultos, no tamanho da população de ninfas, além de um aumento no periodo de desenvolvimento do inseto. Os últimos autores, em outro trabalho, mas estudando o mesmo sistema (HOFFMAN \& HOGG, 1992), confirmaram os estudos anteriores e mostraram que insetos daquela espécie têm preferência por plantas que não estejam sob estresse hídrico. Provaram que a dispersão dessa cigarrinha está ligada ao déficit hidrico, isto é, quanto maior o déficit,

\footnotetext{
${ }^{10}$ Dr. João Spotti Lopes, Departamento de Entomologia, ESALQ/USP, em comunicação pessoal, 1996.
} 
maior a tendência de haver dispersão à procura de hospedeiros mais adequados. Notaram, ainda, que as menores densidades de inseto nas plantas com déficit hídrico deviam-se às suas migrações para plantas mantidas sob regime hídrico satisfatório. Também TRICHILO et alii (1990), trabalhando com uma cigarrinha em videira, encontraram resultados similares em relação à adequação das plantas aos insetos. HOFFMAN et alii (1991) comentam que os fatores que potencialmente afetam a adequação da planta como hospedeira, quando da indisponibilidade de água, são a sua qualidade nutricional, o conteúdo de água de seus tecidos, o microambiente e a concentração de metabólitos secundários na planta. Em patossistemas envolvendo $X$. fastidiosa também já foram encontradas evidências desse tipo de relação entre plantas e vetores. PURCELL \& FRAZIER (1985) afirmaram que as gramíneas de pastos permanentemente irrigados são os hospedeiros preferenciais de Draeculocephala minerva, vetor de $X$. fastidiosa para videira e alfafa na Califórnia. De acordo com eles, as populações de cigarrinhas são mais altas nas porções mais úmidas dos campos ou naquelas em que a drenagem é deficiente. ANDERSEN et alii (1992), estudando o comportamento de um vetor de $X$. fastidiosa em pessegueiro, a cigarrinha Homalodisca coagulata, demonstraram uma diminuição exponencial na taxa de alimentação do inseto conforme se aumentava a tensão xilemática. Em adição, WINKLER et alii (1949) ${ }^{11}$, apud PURCELL \& FRAZIER (1985), informam que as maiores epidemias da doença de Pierce tendem a ocorrer após anos mais úmidos. Para isso, PURCELL \& FRAZIER (1985) sugerem que a explicação mais provável é a de que em épocas mais úmidas há uma expansão das áreas mais adequadas às populações de vetores e que essas áreas permaneceriam propícias por mais tempo, até a primavera ou inicio do verão. Isso possibilitaria que os vetores se dispersassem de forma mais ampla.

Segundo LOPES et alii (1996), até o momento foram identificadas três espécies de cigarrinhas que, comprovadamente, transmitem o agente causal da CVC. Essas cigarrinhas (Acrogonia terminalis, Dilobopterus costalimai e Oncometopia sp.), dentro do agrossistema citrícola, são mais encontradas nas plantas cítricas que em outras espécies. Pelo menos as duas primeiras têm por hábito se alimentar apenas em brotações novas $^{12}$ e são mais observadas bem cedo pela manhã ou no final das tardes ${ }^{13}$,

\footnotetext{
${ }^{11}$ WINKLER, A.J.; HEWITT, W.B.; FRAZIER, N.W. \& FREITAG, J.H. Pierce's disease investigations. Hilgardia 19: 207-264, 1949.

${ }^{12}$ Dr. João Spotti Lopes, Departamento de Entomologia, ESALQ/USP, em comunicação pessoal, 1996.
} 
justamente os horários em que o xilema apresenta as menores tensões (SALISBURY \& ROSS, 1985), ou seja, momentos em que seria mais fácil o ato de sugar. Também para a doença "phony" do pessegueiro, MIZELL \& FRENCH (1987) mostraram que as cigarrinhas Homalodisca coagulata e $H$. insolita, vetores de $X$. fastidiosa nesse patossistema, têm grande preferência por se alimentar em ramos novos, em detrimento dos velhos. Ainda nessa linha, no norte da Califórnia, PURCELL (1976) observou que a cigarrinha envolvida com a doença de Pierce (Hordnia circellata = Graphocephala atropunctata) foi mais encontrada em ramos novos de crescimento vigoroso. Em videira, o vetor foi raramente encontrado em plantas com menor produção de "novas e luxuriantes brotações". Em plantas superiores já foi estabelecido que tecidos em crescimento apresentam maiores concentraçōes de nitrogênio (MARSCHENER, 1995) e laranjas doces (Citrus sinensis (L.) Osb.) não são exceção (CHAPMAN, 1968). Por outro lado, como salientaram HOFFMAN et alii (1991), o comportamento dos insetos pode se relacionar com a qualidade nutricional do hospedeiro, notadamente com a disponibilidade de nitrogênio. Considerando a relação insetos-nutrição mineral de plantas, de acordo com DALE (1988), o aumento populacional de insetos pode ocorrer após aplicação de fertilizantes à base de nitrogênio e, mais ainda, que as concentraçōes de compostos nitrogenados influenciam a dinâmica populacional de insetos sugadores. Em um patossistema que tem $X$. fastidiosa como eixo, já foi demonstrada a influência de compostos nitrogenados na alimentação do vetor. BROADBECK et alii (1990), estudando o comportamento de Homalodisca coagulata, cigarrinha transmissora daquela bactéria em pessegueiro, consideraram que aminoácidos são determinantes de sua preferência hospedeira. Segundo esses autores, a população do inseto aumentava nas quatro espécies de plantas usadas, conforme o aumento na concentração de aminoácidos nos tecidos de cada uma delas. Além disso, a comparação entre espécies, em cada época, mostrou que o hospedeiro preferido era sempre o que continha maiores niveis de aminoácidos. ANDERSEN et alii (1992), por sua vez, trabalhando com o mesmo inseto, e estudando sua taxa de alimentação em relação aos compostos químicos do fluido xilemático, sugerem que amidas são fagoestimulantes para aquela cigarrinha. Mesmo considerando apenas nitrogênio total, ROSSI \& STRONG (1991) demonstraram que, para uma espécie de Cameocephala, as fêmeas adultas preferiram

\footnotetext{
${ }^{13}$ Antônio Garcia Jr, Casa da Agricultura de Neves Paulista - DIRA de São José do Rio Preto Coordenadoria de Assistência Técnica Integral (CATT), em comunicação pessoal, 1995.
} 
se alimentar em plantas com os mais altos niveis daquele nutriente nas folhas. Esse gênero de cigarrinha já foi relacionado à transmissão de $X$. fastidiosa, através da espécie C. fulgida (PURCELL \& FRAZIER, 1985). Em todos os talhöes examinados no presente estudo as adubaçōes foram feitas entre primavera e verão. Uma atenção especial é dada a aplicações de adubos nitrogenados, como por exemplo o Nitrocálcio, visando a florada, mas também o crescimento vigoroso dos fluxos de brotação que acontecem nessa época do ano. Nesse contexto, é possivel que tais práticas sejam uma constante na citricultura paulista, já que o parcelamento da adubação para citros é recomendado para o período entre setembro e março pelo Grupo Paulista de Recomendação de Adubação e Calagem dos Citros (LARANJA, 1994). Ainda de acordo com esse Grupo, as necessidades de plantas cítricas em formação (até 5 anos de idade) são proporcionalmente maiores que as de plantas em produção. Esse é o caso de todas as áreas estudadas. Embora não se tenha conseguido relacionar nutrição mineral com a CVC (MALAVOLTA et alii, 1990; WUTSCHER et alii, 1994), as abordagens, até o momento, têm sido reducionistas, direcionadas à influência dos nutrientes na manifestação da doença. Ainda não se estudou o efeito indireto da nutrição mineral na preferência dos vetores ou no seu ciclo de vida.

\subsubsection{Ciclo da Clorose Variegada dos Citros: um modelo}

A partir da discussão acima, foi elaborado um modelo de comportamento dos vetores de $X$. fastidiosa no patossistema CVC. Esse modelo sugere que a população de vetores que se alimenta em plantas cítricas aumenta nas épocas favoráveis ao desenvolvimento das plantas (primavera e verão) e, ao contrário, diminui no outono/inverno. $O$ aumento populacional estaria relacionado às boas condições para 0 desenvolvimento dos insetos, mas também às migrações. De forma complementar, a diminuição no número de vetores estaria ligada ao baixo desenvolvimento da população, associada à dispersão (em busca de locais favoráveis à sua sobrevivência). Dessa forma, é proposta a ocorrência da seguinte corrente de fatos:

(i) Primavera/Verão: ocorrência de chuvas e aumento de temperatura; diminuição do déficit hidrico; novas brotações, tanto em plantas sadias quanto em doentes; imigração de vetores para os hospedeiros preferenciais e adequados (plantas cítricas); crescimento da população de vetores em função de condições climáticas 
favoráveis (aumento de temperatura) e da existência de alimento em abundância; altas taxas de transmissão e infecção.

(ii) Outono/lnverno: diminuição de chuvas e temperatura; aumento do défict hídrico; ausência de novas brotações e depauperamento da vegetação existente; migração da população de vetores em busca de hospedeiros mais adequados; diminuição progressiva da população não-migrante em função de condições climáticas desfavoráveis e ausência de vegetação adequada no hospedeiro preferencial; diminuição das taxas de transmissão e infecção.

Dentro do contexto proposto por esse modelo, são notáveis as observações feitas por GARCIA Jr. et alii (1996a; 1996b). Esses autores estudaram a flutuação populacional de cigarrinhas em pomares de laranja Pera de três a seis anos de idade, com ou sem aplicação de inseticidas, em quatro municípios da região noroeste de São Paulo. Eles não apresentam resultados separados para cada espécie, mas observaram o comportamento apenas daquelas usadas por LOPES et alii (1996) em testes de transmissão. Nos dois trabalhos, aqueles autores constataram que a densidade das populações começa a aumentar a partir de janeiro, ocorrendo o pico em abril. A partir de maio e até setembro, notaram que a população diminuiu de forma gradativa, estabilizando-se em níveis baixos até dezembro. Os autores chegaram à conclusão de que "o crescimento populacional das cigarrinhas acompanha o crescimento vegetativo da laranjeira". Para áreas onde houve aplicação de inseticidas organofosforados, os autores comentam que, apesar do controle ter sido eficiente, a recomposição da população de cigarrinhas tendeu a ser rápida no período de maior vegetação das plantas. Em contraste, observaram uma recomposição bem mais lenta no periodo de maio a outubro.

\subsubsection{Detalhamento do modelo}

Muito pouco se sabe sobre a epidemiologia da CVC e tentativas de traçar paralelos com outros patossistemas que envolvem $X$. fastidiosa podem não oferecer boas perspectivas ${ }^{14}$. Tais patossistemas abrangem plantas como a videira e a ameixeira

\footnotetext{
${ }^{14}$ Dr.Alexander Purcell, $\mathrm{PhD}$ em entomologia, Universidade da Califórnia: palestra no I Simpósio Internacional sobre Vetores em Relação a Doenças dos Citros, 1996.
} 
que, ao contrário dos citros, são decíduas. Apesar disso, a transmissão do patógeno por cicadelídeos em citros já foi comprovada (LOPES et alii, 1996), da mesma forma que para outros patossistemas que têm $X$. fastidiosa como pivô. Assim, pode-se admitir que a relação vetor-patógeno seja do mesmo tipo que ocorre em outros sistemas que envolvem Xylella (PURCELL \& HOPKINS, 1996), ou seja, quando o inseto adulto adquire a bactéria, transmite-a por toda sua vida. Ademais, assim como nos outros sistemas, a bactéria pode ser encontrada em plantas hospedeiras alternativas, próximas aos pomares citricos (HARAKAVA et alii, 1994).

Pelo que pôde ser demonstrado ou sugerido neste trabalho, alguns pontos podem ser relembrados, já que são a base da proposta: (i) As maiores taxas de progresso da doença ocorrem em certas épocas do ano, coincidindo com os períodos de maior crescimento vegetativo das plantas cítricas. A época de menor progresso ocorre no outono/invemo, quando há déficit hídrico e pouco desenvolvimento vegetativo. (ii) Talhões contaminados na vizinhança são fontes de inóculo. (iii) Matas podem ser fonte de inóculo. (iv) Há transmissão planta a planta dentro das plantações (v) Deve-se admitir que o período de incubação é de, no mínimo, 6 meses, considerando os resultados de LOPES et alii (1996). Por outro lado, ROSENBERGER (1982) afirma que esse período, relacionado a outros patossistemas envolvendo Xylella, é de pelo menos um ano, existindo evidências de que, no campo, o período de incubação da CVC gire em torno de 12 a 14 meses $^{15}$. Ponderando essas informações e mesmo admitindo-se um periodo latente menor que o de incubação (o que realmente deve ocorrer), o progresso da doença observado nas ondas de primavera e verão deve ter origem em infecções ocorridas no ano anterior. Admitindo esses pressupostos, é razoável considerar a situação descrita a seguir:

A princípio pode-se considerar um determinado pomar como isento de $X$. fastidiosa, quer nas plantas cítricas, quer em plantas invasoras. Em conseqüência, admite-se que o inóculo virá de fora, através dos vetores. Para adquirir a bactéria, os insetos deverão se alimentar em pomares vizinhos contaminados ou em plantas próximas que contenham o procarioto. Como já discutido, $X$. fastidiosa tem uma ampla gama de hospedeiros, o que facilita sua sobrevivência. Além disso, e tendo em mente que sua relação com os vetores deve ser duradoura, a bactéria conseguiria se manter no

\footnotetext{
${ }^{15}$ Francisco F. Laranjeira, PqC I, Centro de Citricultura Sylvio Moreira - IAC, não publicado.
} 
interior dos insetos até ser introduzida em hospedeiro compatível. A disseminação da bactéria pode se dar através de material de propagação ou de mudas contaminadas. Essa disseminação predominaria para longas distâncias, contribuindo para a introdução e/ou aumento do inóculo inicial da doença em outras áreas. No âmbito microgeográfico, entretanto, em que mais importa a disseminação a curtas distâncias, ou seja, entre plantas de um talhão ou entre talhōes, os vetores, cicadelídeos no sistema discutido, seriam os agentes fundamentais desse processo.

Tendo como válida a discussão em que se relacionou clima e qualidade física e nutricional do hospedeiro com hábito dos vetores, pode-se imaginar uma situação em que os insetos seriam atraídos, para hospedeiros mais adequados no período da primavera/verão. Considerando aquela área hipotética livre do patógeno, ela seria, assim, contaminada. Ao término do verão, com a ocorrência de menores temperaturas e a ocorrência de déficit hídrico, as plantas cítricas ficam menos adequadas àqueles insetos. Podem ocorrer, então, dois fenômenos distintos: dispersão para hospedeiros que permaneçam adequados (matas ciliares, por exemplo) ou manutenção de níveis populacionais muito baixos em citros. Nessa época, poucas infecções aconteceriam. Por conseguinte, na próxima estação de crescimento, ou haveria migração para os citros ou a população existente iniciaria um incremento. No primeiro caso, após um período de adaptação, um aumento populacional também teria curso. Em ambas as situações, seria esse aumento populacional do vetor o responsável pelas infecções secundárias, a partir, principalmente, daquelas plantas contaminadas um ano antes.

Nas fases em que a relação patógeno-inseto não é duradoura (estádios ninfais), os insetos não são alados e, por isso, tendem a permanecer no local em que os ovos foram postos. Quando podem migrar voluntariamente para outras plantas já adquiriram a bactéria e a transmitirão por toda vida. Assim, e supondo que os insetos se desenvolveram em planta infectada, não apenas serão as plantas recém-contaminadas que atuarão como catalisadoras da epidemia, mas também os insetos que adquiriram o procarioto.

Admitindo o modelo logístico como simplificação válida para o período de primavera/verão, a taxa de progresso da doença seria altamente influenciada pela população inoculativa do vetor. Nesse caso, o termo população inoculativa deixaria de 
representar apenas uma proporção, mas seria a expressão daquela fatia populacional que realmente teve acesso a plantas doentes e sadias. É claro, entretanto, que essa população inoculativa do vetor é função do crescimento populacional dos insetos e da percentagem de aquisição da bactéria pelos mesmos, ou seja, a fração populacional que efetivamente se tornou inoculativa. Em conseqüência, essa percentagem de aquisição deve ser diretamente relacionada com a proporção de plantas infectadas. Além disso, a população inoculativa, nos termos aqui descritos, seria também função do seu comportamento de dispersão e pouso e dos fatores que influenciam esse comportamento. Assim, resumidamente, a taxa de progresso da doença seria função da proporção de hospedeiro doente e da dinâmica populacional dos vetores.

Essa teoria está conforme os dados de distribuição espacial obtidos e que fazem parte dos pressupostos desse modelo, e também com os conhecimentos já existentes sobre a Clorose Variegada dos Citros, em especial quanto ao tipo e comportamento dos vetores envolvidos. É compatível também com o que já se sabe e pode ser extrapolado a partir de outros sistemas que englobam $X$. fastidiosa, e toma complementares os únicos estudos sobre o progresso da doença, em que as unidades observacionais são plantas (GOTTWALD et alii, 1993; NELSON, 1996). 


\section{CONCLUSÕES}

- As taxas de progresso da CVC são variáveis ao longo do tempo.

- As épocas de maior progresso correspondem aos periodos de maior crescimento vegetativo das plantas cítricas e as de menor progresso correspondem às épocas de ocorrência de déficit hídrico e menor desenvolvimento das plantas.

- O modelo logístico generalizado com cinco parâmetros, que apresenta padrão sigmóide duplo, foi o mais adequado na caracterização do progresso da doença durante o periodo de tempo considerado.

- A distribuição espacial de plantas afetadas por CVC dá-se em agrupamentos, coerente com as hipóteses de baixa mobilidade e agregação dos vetores, bem como com a hipótese de transmissão planta a planta dentro do pomar.

- Não houve influência de passagem de máquinas ou do vento na disseminação da doença nas áreas estudadas.

- As maiores concentrações de plantas com CVC foram associadas às bordas de talhões vizinhos a pomares contaminados. 


\section{REFERÊNCIAS BIBLIOGRÁFICAS}

AGOSTINI, J.P.; GOTTWALD, T.R.; TIMMER, L.W. Temporal and spatial dynamics of postbloom fruit drop of citrus in Florida. Phytopathology, v.83, p.485-490, 1993.

AGRIOS, G.N. Plant Pathology. 3.ed. New York: Academic Press, Inc., 1988. 803p.

ALDERMAN, S.C.; NUTTER Jr., F.W.; LABRINOS, J.L. Spatial and temporal analysis of spread of late leaf spot of peanut. Phytopathology, v.79, p.837-844, 1989.

AMARELINHO: solução pode estar no campo. Revista do Fundecitrus, v.12, n.78, p.6-7, set/out, 1996.

AMORIM, L.; BERGAMIN FILHO, A. Sugarcane smut development models: I. Annual curves of disease progress. Z. Pflanzenkrankh. Pflanzenschutz, v.98, p.605-612, 1991.

AMORIM, L.; BERGAMIN FILHO, A.; HAU, B. Analysis of progress curves of sugarcane smut on different cultivars using functions of double sigmoid pattern. Phytopathology, v.83, p.933-936, $1993 a$.

AMORIM, L.; BERGAMIN FILHO, A.; PALAZZO, D.A.; BASSANEZI, R.B.; GODOY, C.V.; TORRES, G.A.M. Clorose Variegada dos Citros: uma escala diagramática para avaliação da severidade da doença. Fitopatologia brasileira, v.18, n.2, p.174-180, 1993b.

ANDERSEN, P.C.; BROADBECK, B.V.; MIZELL III, R.F. Feeding by the leafhopper, Homalodisca coagulata, in relation to xylem fluid chemistry and tension. Journal of Insect Physiology, v.38, n.8, p.611-622, 1992. 
ANDRADE, E.R. Doenças do pessegueiro e da ameixeira e seu controle no estado de Santa Catarina. Florianópolis: EPAGRI, 1995. 52p. (EPAGRI. Boletim Técnico, 71).

AUBERT, B.; SABINE, A.; GESLIN, P.; PICARD, L. Epidemiology of the Greening disease in Reunion island before and after the biological control of the african and asian citrus psyllas. Proc. Int. Soc. Citriculture, p. 440-442. 1984.

BANZATTO, D.A.; KRONKA, S. do N. Experimentação Agrícola. 3.ed. Jaboticabal: FUNEP e FCAVIUNESP, 1995. 247p.

BERETTA, M.J.G.; COELHO, R.C.S.; LEAL, A.M.B.; GAMA, T.T.; LEE, R.F.; DERRICK, K.S. Tahiti lime is tolerant to Citrus Variegated Chlorosis. Fitopatologia brasileira, v.18, p.277, 1993. Suplemento. IApresentado ao 26. Congresso Brasileiro de Fitopatologia, Aracaju, 1993 - Resumo/

BERETTA, M.J.G.; CONTRERAS, J.; LEE, R.F.; CHAGAS, C.M.; MARMELICS, L.; DE NEGRI, J.; DERRICK, K.S. Similarity between citrus variegated chlorosis (CVC) in Brazil and Pecosita in Argentina. Summa Phytopathologica, v.18, n.1, p.6, 1992. IApresentado ao 12. Congresso Paulista de Fitopatologia, Jaboticabal, 1992 Resumo/

BERETTA, M.J.G.; LEE, R.F.; DERRICK, K.; BACH, E.E.; TEIXEIRA, A.R.R.; ROSSETI, V. Serological studies on Xylella fastidiosa associated with citrus variegated chlorosis in Brazil. In: International Plant Protection Congress, 12., Rio de Janeiro, 1991. Contributed papers : Oral and Posters sessions- programs and abstracts. Rio de Janeiro: IPPS, 1991. 1v.

BERETTA, M.J.G.; LEE, R.F.; DERRICK, K.S.; SANTIAGO OLIVEIRA, J.R.; TOMÉ NETO, J.; RODRIGUES, A.L.; TEIXEIRA, A.R. Remission of citrus variegated chlorosis (CVC) symptoms by treatment with Oxytetracycline. Summa Phytopathologica, v.18, n.1, p.5, 1992. IApresentado ao 12. Congresso Paulista de Fitopatologia, Jaboticabal, 1992 - Resumo/

BERGAMIN FILHO, A.; AMORIM, L. Doenças de Plantas Tropicais: Epidemiologia e Controle Econômico. São Paulo: Ed. Agronômica Ceres, 1996. 289p. 
BERGER, R.D. Application of epidemiological principles to achieve plant disease control. Annu. Rev. Phytopathol., v.15, p.165-183, 1977.

BERGER, R.D. Comparison of the Gompertz and logistic equations to describe plant disease progress. Phytopathology, v.71, p.716-719, 1981.

BERGER, R.D. The analysis of effects of control measures on the development of epidemics. In: J. KRANZ; J. ROTEM (Eds.) Experimental Techniques in Plant Disease Epidemiology. Berlin: Springer-Verlag, 1988. cap.9, p.137-151.

BERGER, R.D.; LUKE, H.H. Spatial and temporal spread of oat crown rust. Phytopathology, v.69, p.1199-1201, 1979.

BOITEUX, L.S.; REIFSCHNEIDER, F.J.B. Identificação e caracterização da resistência do tipo redutora de taxa de progresso do crestamento foliar (Altemaria solani) em clones e cultivares de batata. Fitopatologia brasileira, v.18, n.1, p.8690, 1993.

BRITISH MYCOLOGICAL SOCIETY. Some further definitions of terms used in plant pathology. Trans. Br. Mycol. Soc., v.31, p.140-141, 1953.

BRLANSKY, R.H., TIMMER, L.W., LEE, R.F. Detection and transmission of a gramnegative, xylem-limited bacterium in sharpshooters from a citrus grove in Florida. Plant Disease, v.66, p.590-592, 1982.

BROADBECK, B.V.; MIZELL III, R.F.; FRENCH, W.J.; ANDERSEN, P.C.; ALDRICH, J.H. Amino acids as determinants of host preference for the xylem feeding leafhopper, Homalodisca coagulata (Homoptera: Cicadellidae). Oecologia, v.83, p.338-345, 1990.

BUNTIN, G.D. Sampling techniques, population dispersion, and sampling plans for leafhoppers (Homoptera: Cicadellidae) in bermudagrass. Environmental Entomology, v.17, n.5, p.872-877, 1988.

CAMPBELL, C.L.; MADDEN, L.V. Introduction to Plant Disease Epidemiology. New York: John Wiley \& Sons, Inc., 1990. 532p. 
CAMPBELL, C.L.; VAN DER GAAG, D.J. Temporal and spatial dynamics of microsclerotia of Macrophomina phaseolina in three fields in North Carolina over four to five years. Phytopathology, v.83, p.1434-1440, 1993.

CARMO, M.G.F.; MAFFIA, L.A.; HALLER, M.C.P.; ARAÚJO, G.A.A. Progresso e disseminação da antracnose do feijoeiro nos sistemas de monocultivo e de consórcio com o milho. Fitopatologia brasileira, v.19, n.2, p.183-188, 1994.

CARVALHO, S.A.; LARANJEIRA, F.F. Protótipo de viveiro de mudas certificadas e borbulheiras sob telado à prova de afídeos do Centro de Citricultura-IAC. Laranja, v.15, n.2, p.213-220, 1994.

CHAGAS, C.M.; ROSSETI, V.; BERETTA, M.J.G. Electron microscopy studies of a xylem-limited bacterium in sweet orange affected with citrus variegated chlorosis disease in Brazil. Journal of Phytopathology, v.134, p.300-312, 1992.

CHAN, M.; JEGER, M.J. An analytical model of plant virus disease dynamics with roguing and replanting. Journal of Applied Ecology, v.31, p.413-427, 1994.

CHANG, C.J.; GARNIER, M.; ZREIK, L.; ROSSETI, V.; BOVÉ, J.M. Culture and serological detection of the xylem-limited bacterium causing citrus variegated chlorosis and its identification as a strain of Xylella fastidiosa. Current Microbiology, v.27, n.3, p.137-142, 1993.

CHAPMAN, H.D. The mineral nutrition of citrus. In: REUTHER, W.; BATCHELOR, L.D.; WEBBER, H.J. (Eds.) The Citrus Industry, v.ll. Anatomy, physiology, mineral nutrition, seed reproduction, genetics and growth regulators. Riverside: Univ. California, 1968. cap.3, p.127-289.

CHELLEMI, D.O.; ROHRBACH, K.G.; YOST, R.S.; SONODA, R.M. Analysis of the spatial pattern of plant pathogens and diseases plants using geostatistics. Phytopathology, v.78, p.221-226, 1988.

CHELLEMI, D.O.; SONODA, R.M.; PELOSI, R.R.; COHEN, M. Temporal and spatial comparasions between epidemics of citrus blight and citrus tristeza virus. In: IOCV 
CONFERENCE, 11., Riverside, 1991. Proceedings. Riverside: International Organization of Citrus Virologists, 1991. p.289-296.

COLETTA FILHO, H.D.; MACHADO, M.A.; TARGON, M.L.P.N. Detecção de Xylella fastidiosa da clorose variegada dos citros através de PCR. Fitopatologia brasileira, v.21, p.343, 1996. Suplemento. IApresentado ao 29. Congresso Brasileiro de Fitopatologia, Campo Grande, 1996 - Resumo/

CONTRERAS, J. Pecosita ou "Falsa mancha grascienta" na Argentina. Laranja \& CIA, v.31, p.6, jan/fev/mar, 1992.

COSTA, A.S. Present status of the tristeza disease of Citrus in South America. FAO Plant Protection Bull., v.4, p.97-105, 1956.

DALE, D. Plant-mediated effects of soil mineral stresses on insects. In: HEINRICHS, E.A. (Ed.) Plant Stress-Insect Interactions. New York: John Wiley \& Sons, 1988. cap.3, p.35-110.

DE NEGRI, J.D.; GARCIA Jr., A. Sugestões para o manejo de pomares com Clorose Variegada dos Citros. Laranja, v.14, n.1, p.255-267, 1993.

DHANVATARI, B.N.; DIRKS, V.A. Bacterial stem rot of greenhouse tomato: etiology, spatial distribution, and the effect of high humidity. Phytopathology, v.77, p.1457$1463,1987$.

EISENSMITH, S.P.; JONES, A.L.; FLORE, J.A. Predicting leaf emergence of 'Montmorency' sour cherry from degree-day accumulations. J. Amer. Soc. Hort. Sci., v.105, n.1, p.75-78, 1980.

FRENCH, W.J. The incidence of phony disease in wild plum trees as determined by histochemical and microscopic methods. Proc. Fla. State Hort. Soc., v.89, p.241243, 1976.

GARCIA Jr., A.; MAGGIONE, C.S.; TEÓFILO SOBRINHO, J.; POMPEU Jr., J.; DE NEGRI, J.D.; QUAGGIO, J.A.; BERETTA, M.J.G.; GRAVENA, S.; RODAS, V.Z. Como conviver com a CVC em São Paulo. Laranja, v.16, n.2, p.145-154, 1995. 
GARCIA Jr., A.; PARADELA FILHO, O.; SUGIMORI, M.H.; RIBEIRO, I.J.A. Flutuação populacional das cigarrinhas dos citros na variedade Pera Rio na região de São José do Rio Preto. Summa Phytopathologica, v.22, n.1, p.67, 1996a. IApresentado ao 19. Congresso Paulista de Fitopatologia, Campinas, 1996 Resumo/

GARCIA Jr., A.; PARADELA FILHO, O.; SUGIMORI, M.H.; RIBEIRO, I.J.A. Flutuação populacional das cigarrinhas dos citros na variedade Pera Rio com controle quimico na região de São José do Rio Preto. Summa Phytopathologica, v.22, n.1, p.67, 1996b. IApresentado ao 19. Congresso Paulista de Fitopatologia, Campinas, 1996 - Resumo/

GIBBONS, J.D. Nonparametric Methods for Quantitative Analysis. New York: Holt, Rinehart \& Winston, 1976. 463p.

GILLIGAN, C.A. Modeling of soilborne pathogens. Ann. Rev. Phytopathol., v.21, p.45-64, 1983.

GOHEEN A.C.; NYLAND, G.; LOWE, S.K. Association of a rickettsialike organism with Pierce's disease of grapevine and alfalfa dwarf and heat therapy of the disease in grapevines. Phytopathology, v.63, p.341-345, 1973.

GOTTWALD, T.R. Spatio-temporal analysis and isopath dynamics of citrus scab in nursery plots. Phytopathology, v.85, p.1082-1092, 1995.

GOTTWALD, T.R.; AUBERT, B.; LONG, H.K. Spatial pattern analysis of citrus greening in Shantou, China. In: IOCV CONFERENCE, 11., Riverside, 1991. Proceedings. Riverside: International Organization of Citrus Virologists, 1991b. p.421-427.

GOTTWALD, T.R.; AUBERT, B.; XUE-YUAN, Z. Preliminary analysis of citrus greening (Huanglongbin) epidemics in the People's republic of China and french Reunion Island. Phytopathology, v.79, p.687-693, 1989a. 
GOTTWALD, T.R.; AVINENT, L.; LLACER, G.; HERMOSO DE MENDOZA, A.; CAMBRA, M. Analysis of spatial spread of sharka (plum pox virus) in apricot and peach orchards in eastem Spain. Plant Disease, v.79, p.266-278, 1995.

GOTTWALD, T.R.; CAMBRA, M.; MORENO, P.; CAMARASA, E.; PIQUER, J. Spatial and temporal analysis of citrus tristeza virus in eastern Spain. Phytopathology, v.86, p.45-55, 1996.

GOTTWALD, T.R.; GIDTTI, F.B.; SANTOS, J.M.; CARVALHO, A.C. Preliminary spatial and temporal analysis of Citrus Variegated Chlorosis (CVC) in São Paulo, Brazil. In: IOCV CONFERENCE, 12., Riverside, 1993. Proceedings. Riverside: International Organization of Citrus Virologists, 1993. p.327-335.

GOTTWALD, T.R.; GONZALES, C.I.; MERCADO, B.G. Analysis of the distribution of citrus greening in groves in the Philippines. In: IOCV CONFERENCE, 11., Riverside, 1991. Proceedings. Riverside: International Organization of Citrus Virologists, 1991a. p.414-420.

GOTTWALD, T.R.; GRAHAM, J.H. Analysis of epidemics of citrus bacterial spot in Florida citrus nurseries. Proc. Fla. State Hort. Soc., v.104, p.163-168, 1991.

GOTTWALD, T.R.; REYNOLDS, K.M.; CAMPBELL, C.L.; TIMMER, L.W. Spatial and spatiotemporal autocorrelation analysis of citrus canker epidemics in citrus nurseries and groves in Argentina. Phytopathology, v.82, p.843-851, 1992.

GOTTWALD, T.R.; TIMMER, L.W.; McGUIRE, R.G. Analysis of disease progress of citrus canker in nurseries in Argentina. Phytopathology, v.79, p.1276-1283, 1989b.

GREIG-SMITH, P. Quantitative Plant Ecology. 3 ed. Berkeley:University of California Press, 1983. 359p. (Studies in ecology v.9)

HARAKAVA, R.; TEBAR, L.R.; BERETTA, L.; DE JESUS, C.B.; ALBA, A.P.C.; BERETTA, M.J.G. Detection of Xylella fastidiosa antigens in weeds collected from citrus orchards affected by Citrus Variegated Chlorosis (CVC). Fitopatologia 
brasileira, v.19, p.319, 1994. Suplemento. IApresentado ao 27. Congresso Brasileiro de Fitopatologia, Itajai, 1994 - Resumo/

HAU, B. Modelling epidemics of polycyclic foliar diseases and development of simulators. In: J. KRANZ; J. ROTEM (Eds.) Experimental Techniques in Plant Disease Epidemiology. Berlin: Springer-Verlag, 1988. cap.19, p.267-277.

HAU, B.; AMORIM, L.; BERGAMIN FILHO, A. Mathematical functions to describe disease progress curves of double sigmoid pattem. Phytopathology, v.83, p.928932, 1993.

HEADY, S.E.; NAULT, L.R. Escape behaviour of Dalbulus and Baldulus leafhoppers (Homoptera: Cicadellidae). Environmental Entomology, v.14, n.2, p.154-158, 1985.

HERNANDEZ-GARBOSA, L.; OCHOA-CORONA, F. Diagnostico de Xylella fastidiosa en la vid y malezas asociadas con el cultivo. Manejo Integrado de Plagas, v.33, p.7-10, 1994.

HOFFMAN, G.D.; HOGG, D.B. Effect of alfalfa water stress on potato leafhopper (Homoptera: Cicadellidae) plant preference and oviposition rate. Ann. Entomol. Soc. Am., v.85, n.4, p.506-516, 1992.

HOFFMAN, G.D.; HOGG, D.B. Potato leafhopper (Homoptera: Cicadellidae) in waterstressed alfalfa: population consequences and field tests. Environmental Entomology, v.20, n.4, p.1067-1073, 1991.

HOFFMAN, G.D.; HOGG, D.B.; BOUSH, G.M. Potato leafhopper (Homoptera: Cicadellidae) life history on water-stressed alfalfa in the early regrowth and bud stage. Environmental Entomology, v.20, n.4, p.1058-1066, 1991.

HOLTZER, T.O.; ARCHER, T.L.; NORMAN, J.M. Host plant suitability in relation to water stress. In: HEINRICHS, E.A. (Ed.) Plant Stress-Insect Interactions. New York: John Wiley \& Sons, 1988. cap. 4, p.111-137.

HOPKINS, D.L. Xylella fastidiosa: Xylem-limited bacterial pathogen of plants. Ann. Rev. Phytopathol., v.27, p.271-290, 1989. 
HOPKINS, D.L.; ADLERZ, W.C. Natural hosts of Xylella fastidiosa in Florida. Plant Disease, v.72, p.429-431, 1988.

HUANG, H.C.; KOZUB, G.C. Cyclic occurrence of Sclerotinia wilt of sunflower in western Canada. Plant Disease, v.74, p.766-770, 1990.

HUGHES, G.; MADDEN, L.V. Aggregation and incidence of disease. Plant Pathology, v.41, p.657-660, 1992.

HUGHES, G.; MADDEN, L.V.; MUNKVOLD, G.P. Cluster sampling for disease incidence data. Phytopathology, v.86, p.132-137, 1996.

JEGER, M.J. The spatial component of plant disease epidemics. In: M.J. JEGER (Ed.) Spatial Components of Plant Disease Epidemics. New Jersey: PrenticeHall, 1989. cap.5, p.1-13. (Prentice Hall Advanced Reference Series, Physical and Life Sciences)

KITAJIMA, E.W.; MOHAN, S.K.; TSUNETA, M.; BLEICHER, J.; FRENCH, W.; LEITE Jr., R.P. Ocorrência da escaldadura das folhas da ameixeira nos estados do Paraná e Santa Catarina. Fitopatologia brasileira, v.6, n.2, p.285-292, 1981.

KRAFT, J.M.; ALLMARAS, R.R. Pea root pathogen populations in relation to soil structure, compaction, and water content. In: C.A. PARKER et al. (Eds.) Ecology and Management of Soilborne Plant Pathogens. Saint Paul: APS PRESS, 1985. p.203-205.

KRANZ, J. Epidemics, their mathematical analysis and modeling: an introduction. In:

J. KRANZ (Ed.) Epidemics of Plant Diseases: mathematical analysis and modeling. 2.ed. Berlin: Springer-Verlag, 1990. cap.1, p.1-11. (Ecological Studies v. 13)

KRANZ, J. The methodology of comparative epidemiology. In: J. KRANZ; J. ROTEM (Eds.) Experimental Techniques in Plant Disease Epidemiology. Berlin: Springer-Verlag, 1988. cap.20, p.279-289. 
LACKNER, A.L; ALEXANDER, S.A. Incidence and development of Verticicladiella procera in Virginia christmas tree plantations. Plant Disease, v.68, p.210-212, 1984.

LARANJA. Recomendações de adubação e calagem para citros no estado de São Paulo. Cordeirópolis, v.15, Edição Especial, 1994. 27p.

LARANJEIRA, F.F. Dez anos de Clorose Variegada dos Citros: o quê sabemos? Laranja, v.18, n.1, p.123-141, 1997.

LARANJEIRA, F.F.; BERETTA, M.J.G.; LEE, R.F.; CASALE, H.; RODRIGUES, W.L.A.; PICIN, C.; FREIRE, G.B. Citrus Declínio/blight: a study on its spatial pattern. Fitopatologia brasileira, v.18, p.334, 1993. Suplemento. IApresentado ao 26. Congresso Brasileiro de Fitopatologia, Aracaju, 1993 - Resumo/

LARANJEIRA, F.F.; GUIRADO, N. Dinâmica do Declínio dos citros em Mogi-Guaçú II. Distribuição espacial. Fitopatologia brasileira, v.19, p.302, 1994. Suplemento. IApresentado ao 27. Congresso Brasileiro de Fitopatologia, Itajaí, 1994 - Resumo/

LARANJEIRA, F.F.; HARAKAVA, R.; CARVALHO, S.A.; POMPEU Jr., J.; FIGUEIREDO, J.O. Avaliação serológica e sintomatológica da ocorrência de Xylella fastidiosa e clorose variegada dos citros (CVC) no Banco Ativo de Germoplasma do IAC. Fitopatologia brasileira, v.21, p.335, 1996. Suplemento. IApresentado ao 29. Congresso Brasileiro de Fitopatologia, Campo Grande, 1996 Resumo/

LARANJEIRA, F.F.; PALAZZO, D. Determinação preliminar dos efeitos da Clorose Variegada dos Citros em características físico-químicas de frutos de laranja Natal. Fitopatologia brasileira, v.19, p.309, 1994. Suplemento. IApresentado ao 27. Congresso Brasileiro de Fitopatologia, Itajai, 1994 - Resumo/

LARANJEIRA, F.F.; POMPEU Jr., J.; GARCIA Jr., A.; VIEIRA, M.; HARAKAVA, R.; BERETTA, M.J.G. Tangelos: highly CVC resistant citrus. In: INTERNATIONAL CONGRESS OF CITRUS NURSERYMEN, 5., Montpellier, 1997. Proceedings. Montpellier: International Society of Citrus Nurserymen, 1997. /No prelo/ 
LARANJEIRA, F.F.; POMPEU JR., J.; HARAKAVA, R. Seleção de variedades resistentes e/ou tolerantes à Clorose Variegada dos Citros (CVC). Fitopatologia brasileira, v.20, p.324, 1995. Suplemento. IApresentado ao 28. Congresso Brasileiro de Fitopatologia, llhéus, 1995 - Resumo/

LARSEN, K.J.; WHALON, M.E. Dispersal of Paraphlesius irronatus (Say) (Homoptera: Cicadellidae) in peach and cherry orchards. Environmental Entomology, v.17, n.5, p.842-851, 1988.

LECOUSTRE, R.; FARGETTE, D.; REFFYE, P. de Analysis and mapping of the spatial spread of African Cassava Mosaic Virus using geostatistics and the kriging technique. Phytopathology, v.79, p.913-920, 1989.

LEE, R.F.; BERETTA, M.J.G.; DERRICK, K.S.; HOOKER, M.E. Development of a serological assay for citrus variegated chlorosis: a new disease of citrus in Brazil. Proc. Fla. State Hort. Soc., v.105, p.32-35, 1992.

LEFÉVRE, A.F.V., BERETTA, M.J.G., ROSSETI, V.; BRLANSKI, R.H.; LEE, R.F. Sharpshooter populations in a Declinio-affected citrus orchard in Brazil. In: IOCV CONFERENCE, 10., Riverside, 1989. Proceedings. Riverside: International Organization of Citrus Virologists, 1989. p.388-393

LEGENDRE, P. Spatial autocorrelation: trouble or new paradigm? Ecology, v.74, n.6, p.1659-1673, 1993.

LEITE Jr, R.P.; LEITE, R.M.V.B.C. Associação de Xylella fastidiosa com a clorose variegada dos citros. Summa Phytopathologica, v.17, n.1, p.7, 1991. IApresentado ao 14. Congresso Paulista de Fitopatologia, Botucatu, 1991 Resumo/

LI, W.; DONADIO, L.C.; SEMPIONATO, O.R. Pesquisas recentes sobre a Clorose Variegada dos Citros na EECB. Informativo Coopercitrus, v.10, n.116, p.20-21, 1996.

LLANOS, J.L.; LIMA, H.; CHÁVEZ, J.O. A statistical method to determine the distribution and expansion of blight. Proc. Int. Soc. Citriculture, p.474-476, 1981. 
LOONEY, S.W.; GULLEDGE Jr., T.R. Use of the correlation coefficient with normal probability plots. The American Statistician, v.39, n.1, p.75-79, 1985.

LOPES, J.R.S.; BERETTA, M.J.G.; HARAKAVA, R.; ALMEIDA, R.P.P.; KRÜGNER, R.; GARCIA Jr., A. Confirmação da transmissão por cigarrinhas do agente causal da Clorose Variegada dos Citros, Xylella fastidiosa. Fitopatologia brasileira, v.21, p. 343, 1996. Suplemento. IApresentado ao 29. Congresso Brasileiro de Fitopatologia, Campo Grande, 1996 - Resumo/

MACHADO, M.A.; SILVÉRIO, J.L.; BAPTISTA, C.R.; CRISTOFANI, M.; TEÓFILO SOBRINHO, J. Avaliação de transmissão e seleção de variedades à Clorose Variegada dos Citros (CVC). Laranja, v.13, n.2, p.515-531, 1992.

MACHADO, M.A.; SILVÉRIO, J.L.; BAPTISTA, C.R.; LARANJEIRA, F.F.; BERETTA, M.J.G. Transmissão e seleção de espécies e variedades a CVC (II). Laranja, v.14, n.1, p.167-176, 1993.

MACHADO, M.A.; TARGON, M.L.P.N.; BERETTA, M.J.G.; LARANJEIRA, F.F.; CARVALHO, S.A. Deteç̧ão de Xylella fastidiosa em espécies e variedades de citros sobre-enxertadas em laranja Pera com clorose variegada dos citros (CVC). Fitopatologia brasileira, v.22, n.1, p.30-33, 1997.

MADDEN, L.V. Dynamic nature of within-field disease and pathogens distributions. In: M.J. JEGER (Ed.) Spatial Components of Plant Disease Epidemics. New Jersey: Prentice-Hall, 1989. cap.5, p.96-126.

MADDEN, L.V. Quantification of disease progression. Prot. Ecol., v.2, p.159-176, 1980.

MADDEN, L.V.; CAMPBELL, C.L. Nonlinear Disease Progress Curves. In: J. KRANZ (Ed.) Epidemics of Plant Diseases: mathematical analysis and modeling. Berlin: Springer-Verlag, 1990. cap.6, p.181-229. (Ecological Studies v.13)

MADDEN, L.V.; ELLIS, M.A. How to develop plant disease forecasters. In: J. KRANZ; J. ROTEM (Eds.) Experimental Techniques in Plant Disease Epidemiology. Berlin: Springer-Verlag, 1988. cap.13, p.191-208. 
MADDEN, L.V.; HUGHES, G. Plant disease incidence: distributions, heterogeneity and temporal analysis. Annu. Rev. Phytopathol., v.33, p.529-564, 1995.

MADDEN, L.V.; HUGHES, G.; ELLIS, M.A. Spatial heterogeneity of the incidence of grape downy mildew. Phytopathology, v.85, p.269-275, 1995.

MADDEN, L.V.; LOUIE, R.; ABT, J.J.; KNOKE, J.K. Evaluation of tests of randomness of infected plants. Phytopathology, v.72, p.195-198, 1982.

MALAVOLTA, E., MALAVOLTA, M.L;; CABRAL, C.P.; PRATES, H.S.; VITTI, G.C. Nova anomalia dos citros - Estudos preliminares. Laranja, v.11, n.1, p.15-38, 1990.

MARCUS, R.; FISHMAN, S.; TALPAZ, H.; SALOMON, R.; BAR-JOSEPH, M. On the spatial distribution of Citrus Tristeza Virus disease. Phytoparasitica, v.12, n.1, p.45-52, 1984.

MARSCHENER, H. Mineral Nutrition of Higher Plants. 2.ed. London: Academic Press, 1995. 889p.

MIZELL, R.F.; FRENCH, W.J. Leafhopper vectors of phony peach disease: feeding site preference and survival on infected and uninfected peach, and seasonal response to selected host plants. Journal of Entomological Science, v.22, n.1, p.11-22, 1987.

NELSON, S.C. A simple analysis of disease foci. Phytopathology, v.86, p.332-339, 1996.

NELSON, S.C.; CAMPBELL, C.L. Comparative spatial analysis of foliar epidemics on white clover caused by viruses, fungi, and a bacterium. Phytopathology, v.83, p.288-301, 1993.

NOE, J.P.; BARKER, K.R. Relation of within-field variation of plant-parasitic nematode population densities to edaphic factors. Phytopathology, v.75, p.247-252, 1985.

ODUM, E.P. Ecologia. Rio de Janeiro: Editora Guanabara, 1988. 434p. 
OLIVETTI, M.P.A.; COELHO, P.J.; NEGRI NETO, P.; CASER, D.V.; DONADELLI, A. O valor da produção das atividades agropecuárias nas regiōes do estado de São Paulo. Informaçōes Econômicas, v.26, n.6, p.39-68, 1996.

ORTOLANI, A.A.; PEDRO Jr., M.J.; ALFONSI, R.R. Agroclimatologia e o cultivo dos citros. In: RODRIGUEZ, O. et al. (Eds.) Citricultura Brasileira, 2.ed., v.1. Campinas: Fundação Cargill, 1991. cap.6, p.153-195.

PALAZZO, D.A., BERETTA, M.J.G., CARVALHO, M.L.V.; BACH, E.E.; ROSSETI, V. Resultados preliminares de estudos sobre o desenvolvimento da Clorose Variegada dos Citros(CVC), pelo seu efeito em frutos no estado de São Paulo. Fitopatologia brasileira, v.16, n.2, p.48, 1991. /Apresentado ao 24. Congresso Brasileiro de Fitopatologia, Rio de Janeiro, 1991 - Resumo/

PALAZZO, D.A.; CARVALHO, M.L.V. Desenvolvimento e progresso da Clorose Variegada dos Citros (CVC) em pomares de Colina, SP. Laranja, v.13, n.2, p.489502, 1992.

PARADELA FILHO, O.; SUGIMORI, M.H.; RIBEIRO, I.J.A.; MACHADO, M.A.; LARANJEIRA, F.F.; GARCIA Jr., A.; BERETTA, M.J.G.; HARAKAWA, R.; ODRIGUES NETO, J.; BERIAM, L.O.S. Primeira constatação em cafeeiro no Brasil, da Xylella fastidiosa causadora da Clorose Variegada dos Citros. Laranja, v.16, n.2, p.135-136, 1995.

PEREIRA, F.M.; SÃO JOSÉ, A.R. Estudos do desenvolvimento dos frutos da goiabeira 'Paluma' e 'Rica'. In: Congresso Brasileiro de Fruticultura, 9., Campinas, 1987. Anais. Campinas:Sociedade Brasileira de Fruticultura, 1988. p.469-474.

PFENDER, W.F. Monocyclic and policyclic diseases: distinguishing between the nature of the disease cycle and shape of the disease progress curve. Phytopathology, v.72, p.31-32, 1982.

POMPEU JR., J.; LARANJEIRA, F.F.; HARAKAVA, R.; BERETTA, M.J.G. Primeira constatação de sintomas foliares de Clorose Variegada dos Citros em tangerinas e híbridos de tangerina. Fitopatologia brasileira, v.19, p.318, 1994 . Suplemento. IApresentado ao 27. Congresso Brasileiro de Fitopatologia, Itajaí, 1994 - Resumo/ 
PREJUizo inicial chegará a US\$ 145 milhões. Folha de São Paulo. Agrofolha, São Paulo, 16 set. 1997. p.5-1.

PURCELL, A.H. Cigarrinhas na cultura de citros. In: L.C. DONADIO; S. GRAVENA (Coords.) Manejo Integrado de Pragas dos Citros. Campinas: Fundação Cargill, 1994. cap.11, p.195-209.

PURCELL, A.H. Seasonal changes in host plant preference of the blue-green sharpshooter Hordnia circellata (Homoptera: Cicadellidae). Pan Pacific Entomologist, v.52, n.1, p.33-37, 1976.

PURCELL, A.H. Spatial patterns of Pierce's disease in the Napa valley. American Journal of Enology and Viticulture, v.25, n.3, p.162-167, 1974.

PURCELL, A.H.; FINLAY, A.H. Evidence for noncirculative transmission of Pierce's disease bacterium by sharpshooters leafhoppers. Phytopathology, v.69, p.393$395,1979$.

PURCELL, A.H.; FINLAY, A.H.; McLEAN, D.L. Pierce's disease bacterium: mechanisms of transmission by leafhopper vectors. Science, v.206, p.839-841. 16 nov., 1979.

PURCELL, A.H.; FRAZIER, N.W. Habitats and dispersal of the principal leafhopper vectors of Pierce's disease bacterium in the San Joaquin Valley. Hilgardia, v.53, p.1-32, 1985.

PURCELL, A.H.; HOPKINS, D.L. Fastidious xylem-limited bacterial plant pathogens. Ann. Rev. of Phytopathol., v.34, p.131-151, 1996.

PUSEY, P.L. Availability and dispersal of ascospores and conidia of Botryosphaeria in peach orchards. Phytopathology, v.79, p.635-639, 1989.

RAJU, B.C.; NOME, S.F.; DOCAMPO, D.; GOHEEN, A.C.; NYLAND, G.; LOWE, S.K. Alternative hosts of Pierce's disease of grapevines that occur adjacent to grape growing areas in California, USA. American Journal of Enology and Viticulture, v.31, n.2, p.144-148, 1980. 
REYNOLDS, K.M.; MADDEN, L.V.; ELLIS, M.A. Spatio-temporal analysis of epidemic development of leather rot of strawberry. Phytopathology, v.78, p.246-252, 1988.

RIPLEY, B.D. Tests of 'randomness' for spatial point patterns. J.R. Statist. Soc. series $B$, v.41, n.3, p.368-374, 1979.

RISTAINO, J.B.; LARKIN, R.P.; CAMPBELL, C.L. Spatial and temporal dynamics of Phytophthora epidemics in commercial bell pepper fields. Phytopathology, v.83, p.312-1320, 1993.

ROBERTO, S.R.; COUTINHO, A.; MIRANDA, V.S.; LIMA, J.E. de O. Associação entre a Clorose Variegada e as cigarrinhas-do-xilema predominantes em citros. Fitopatologia brasileira, v.20, p.348, 1995. Suplemento. IApresentado ao 28. Congresso Brasileiro de Fitopatologia, llhéus, 1995 - Resumo/

RODAS, V.Z. Convivência com a Clorose Variegada dos Citros. Laranja, v.15, n.1, p.129-133, 1994.

ROSENBERGER, D.A. Fastidious Prokaryotes: Epidemiology of the Hidden Pathogens. In: M.S.MOUNT; G.H. LACY (Eds.) Phytopathogenic Prokaryotes, v.2. New York: Academic Press, 1982. cap. 4, p.72-100.

ROSSETI, V.,GARNIER, M.,BOVÉ, J.M. BERETTA, M.J.G.; TEIXEIRA, A.R.; QUAGGIO, J.A.; DE NEGRI, J.D. Présence de bactéries dans le xylème d'orangers atteints de chlorose variégée, une nouvelle maladie des agrumes au Brésil. C.R. Acad. Sci. Paris, t.310, serie III, p.345-349, 1990.

ROSSETI, V.; CARVALHO, M.L.V.; CHAGAS, C.M. Ensaios de transmissão de Clorose Variegada dos Citros (CVC) em campo. Fitopatologia brasileira, v.20, p.351, 1995. Suplemento. IApresentado ao 28. Congresso Brasileiro de Fitopatologia, Ilhéus, 1995 - Resumo/

ROSSETI, V.; De NEGRI, J.D. Clorose variegada dos citros - Revisão. Laranja, v.11, n.1, p.1-14, 1990. 
ROSSI, A.M.; STRONG, D.R. Effects of host - plant nitrogen on the preference and performance of laboratory populations of Cameocephala floridiana (Homoptera: Cicadellidae). Environmental Entomology, v.20, n.5, p.1349-1355, 1991.

SALISBURY, F.B.; ROSS, C.W. Plant Physiology. 3.ed. Belmont: Wadsworth Publishing Company, 1985. 540p.

SEEM, R.C. The Measument and Analysis of the Effects of Crop Development on Epidemics. In: J. KRANZ; J. ROTEM (Eds.) Experimental Techniques in Plant Disease Epidemiology. Berlin: Springer-Verlag, 1988. cap.4, p.51-68.

SHTIENBERG, D.; BLACHINSKY, D.; BEN-HADOR, G.; DINOOR, A. Efects of growing season and fungicide type on the development of Altemaria solani and on potato yield. Plant Disease, v.80, p.994-998, 1996.

SUGIMORI, M.H.; GARCIA Jr, A.; RIBEIRO, I.J.A.; PARADELA FILHO, O. Intensidade da Clorose Variegada dos Citros em laranja Pera Rio de diferentes idades, na região de São José do Rio Preto. Summa Phytopathologica, v.22, n.1, p.67, 1996. IApresentado ao 19. Congresso Paulista de Fitopatologia, Campinas, 1996 Resumo/

SUGIMORI, M.H.; PARADELA FILHO, O.; RIBEIRO, I.J.A.; LARANJEIRA, F.F.; GARCIA Jr, A.; MARTINS, A.L.M. Estudo de transmissão do agente da CVC por semente. Summa Phytopathologica, v.21, n.1, p.58, 1995. IApresentado ao 18. Congresso Paulista de Fitopatologia, Piracicaba, 1995 - Resumo/

TANGELOS resistem à CVC e têm bom aproveitamento industrial. Informativo Coopercitrus, v.10, n.119, p.16-17, 1996.

TAYLOR, L.R. Aggregation, variance and the mean. Nature, v.189, p.732-735, 1961.

TAYLOR, L.R. Assessing and interpreting the spatial distributions of insect populations. Ann. Rev. Entomol., v.29, p.321-357, 1984.

TEBAR, L.R.; HARAKAVA, R.; GRAVENA, S.; YAMAMOTO, P.T.; PAIVA, P.E.B.; ALBA, A.P.C., BERETTA, M.J.G.; LEE, R.F.; DERRICK, K.S. Detection of Xylella fastidiosa antigens in sharpshooter leafhoppers collected from citrus orchards 
affected by Citrus Variegated Chlorosis (CVC). Fitopatologia brasileira, v.19, p.319, 1994. Suplemento. IApresentado ao 27. Congresso Brasileiro de Fitopatologia, Itajaí, 1994 - Resumo/

THOMPSON, C.M. Table of percentage points of the $\chi^{2}$ distribution. Biometrika, v.32, p.168-181, 1941.

TRANGMAR, B.B.; YOST, R.S.; UHARA, G. Application of geostatistics to spatial studies of soil properties. Adv. Agron., v.38, p.45-94, 1985.

TRAVENSOLO, R.F.; LEITE Jr., R.P. Hospedeiros alternativos de Xylella fastidiosa entre plantas invasoras de pomares de citros com clorose variegada. Fitopatologia brasileira, v.21, p.336, 1996. Suplemento. IApresentado ao 29. Congresso Brasileiro de Fitopatologia, Campo Grande, 1996 - Resumo/

TRICHILO, P.J.; WILSON, L.T.; GRIMES, D.W. Influence of irrigation management on the abundance of leafhoppers (Homoptera: Cicadellidae) on grapes. Environmental Entomology, v.19, n.6, p.1803-1809, 1990.

TUBELIS, A. Clima: fator que afeta a produção e qualidade da laranja. Laranja, v.16, n.2, p.179-211, 1995.

UPTON, G.; FINGLETON, B. Spatial data analysis by example, vol.1: Point pattern and quantitative data. New York: John Wiley \& Sons, 1985. 410p.

VAN DER PLANK, J.E. Plant Diseases: Epidemics and Control. New York: Academic Press, 1963. 349p.

WEAVER, D.J.; RAJU, B.C.; WELLS, J.M. Occurrence in johnsongrass of Rickettsialike bacteria related to the phony peach disease organism. Plant Disease, v.64, p.485-487, 1980.

WELLS, J.M.; RAJU, B.C.; HUNG, H.Y.; WEISBURG, W.G.; MANDELCO-PAUL, L.; BRENNER, D.J. Xylella fastidiosa gen. nov., sp. nov.: Gram-negative, xylemlimited, fastidious plant bacteria related to Xanthomonas spp. International Journal of Systematic Bacteriology, v.37, n.2, p.136-143, 1987. 
WINKLER, A.J.; HEWITT, W.B.; FRAZIER, N.W.; FREITAG, J.H. Pierce's disease investigations. Hilgardia, v.19, p.207-264, 1949.

WUTSCHER, H.K.; PAVAN, M.A.; PERKINS, R.E. A survey of mineral elements in the leaves and roots of Citrus Variegated Chlorosis (or amarelinho) affected orange trees and 45 acid-extractable elements in the soils of orchards in northern São Paulo and southern Minas Gerais. Arq. Biol. Tecnol., v.37, n.1, p.147-156, 1994.

ZENTMEYER, G.A. Origin and distribution of Phytophthora cinnamomi. In: C.A. PARKER et al.(Eds.) Ecology and Managemant of Soilborne Plant Pathogens. Saint Paul: APS PRESS, 1985. p.71-72. 